José Guilherme Allen Lima

Práticas de luteria na música experimental brasileira

São Paulo

2018 

José Guilherme Allen Lima

\title{
Práticas de luteria na música experimental brasileira
}

Tese apresentada à Escola de Comunicação e Artes para obtenção do título de Doutor em Música. Área de concentração: Processos de Criação Musical.

\author{
Universidade de São Paulo \\ Escola de Comunicações e Artes \\ Programa de Pós-Graduação em Música
}

Orientador: Fernando Henrique de Oliveira Iazzetta

São Paulo

2018 
José Guilherme Allen Lima

Práticas de luteria na música experimental brasileira/ José Guilherme Allen Lima. - São Paulo, 2018-

221 p. : il. (algumas color.) ; $30 \mathrm{~cm}$.

Orientador: Fernando Henrique de Oliveira lazzetta

Tese (Doutorado) - Universidade de São Paulo

Escola de Comunicações e Artes

Programa de Pós-Graduação em Música, 2018.

1. Música. 2. Luteria. 3. Experimentalismo. I. Fernando Henrique de Oliveira lazzetta. II. Universidade de São Paulo. III. Escola de Comunicação e Artes. IV. Práticas de luteria na música experimental brasileira 
José Guilherme Allen Lima

\section{Práticas de luteria na música experimental brasileira}

Tese apresentada à Escola de Comunicação e Artes para obtenção do título de Doutor em Música. Área de concentração: Processos de Criação Musical.

Trabalho aprovado. São Paulo, de de 2018:

\begin{tabular}{|c|}
\hline $\begin{array}{c}\text { Fernando Henrique de Oliveira } \\
\text { Iazzetta } \\
\text { Orientador }\end{array}$ \\
\hline $\begin{array}{l}\text { Professor } \\
\text { Convidado } 1\end{array}$ \\
\hline $\begin{array}{c}\text { Professor } \\
\text { Convidado } 2\end{array}$ \\
\hline $\begin{array}{c}\text { Professor } \\
\text { Convidado } 3\end{array}$ \\
\hline $\begin{array}{c}\text { Professor } \\
\text { Convidado } 4\end{array}$ \\
\hline $\begin{array}{c}\text { São Paulo } \\
2018\end{array}$ \\
\hline
\end{tabular}



Dedico este trabalho à memória do meu irmão de vida Carlos Eduardo Miranda e do meu avô Jorgera 

Quem tem fornece a bitola onde quem não tem se mede 



\section{Resumo}

LIMA, José Guilherme Allen. Práticas de luteria na música experimental brasileira. 2018. 221 f. Tese (Doutorado) - Escola de Comunicações e Artes, Universidade de São Paulo, São Paulo, 2018.

Este trabalho faz um levantamento da produção brasileira de luteria experimental, com ênfase na produção realizada ao longo das últimas duas décadas. Inicialmente é delineado um panorama de referências relacionadas com este tido de produção na literatura europeia e estadunidense, assim como discutida a atuação de alguns artistas e criadores fundamentais para o estabelecimento de práticas de luteria experimental no século XX. No segundo capítulo faço um levantamento de referências sobre este tipo de produção no Brasil, assim como relaciono artistas em atividade no país nos últimos 20 anos, detalhando na maior parte dos casos algumas de suas obras. Partindo deste panorama, realizo um estudo mais aprofundado sobre o instrumento conhecido por gatorra, fabricado por Tony da Gatorra, artesão, técnico em eletrônica e músico gaúcho que criou seu instrumento nos anos 1990 a partir de materiais de sucata, componentes eletrônicos reaproveitados e da combinação de projetos de circuitos eletrônicos geradores de som. Por fim, relaciono a produção estudada com referenciais que lidam com a noção de cultura material, alguns dos quais já realizam uma aproximação com a atividade musical e artística.

Palavras-chave: Música experimental. Luteria experimental. Readymade. Gambiarra. Desobediência tecnológica. Cultura material. Gatorra. 



\section{Abstract}

This work presents a survey on the Brazilian production of experimental lutherie, with emphasis on the production over the last two decades. A framework of references related to this production in the European and American literature is outlined as an introduction, as well as the works of some key artists and creators whose production influenced experimental instrument building practices in the 20th century. In the second chapter I make a survey of references on this type of production in Brazil, as well a profile of artists active in the country for the last 20 years, detailing in most cases some of his works. Based on this outline, I carry out a more detailed study on the instrument known as gatorra, manufactured by Tony da Gatorra, an artisan, technician and musician who created his instrument in the 1990s from scrap materials, reused electronic components and the combination of electronic circuits sound generators. Finally, I relate the production studied with references that deal with the notion of material culture, some of which already make an approximation with musical and artistic activity.

Keywords: Experimental Music. Experimental Lutherie. Readymade. Gambiarra. Technological desobedience. Material culture. Gatorra. 



\section{Lista de ilustrações}

Figura 1 - Cristal Baschet. Foto: Jean-Marc Anglès para o Musée de la Musique. 33

Figura 2 - Viola adaptada de Harry Partch. . . . . . . . . . . . . . . . . 34

Figura 3 - Quadrangularis Reversum de Harry Partch. . . . . . . . . . . . . 35

Figura 4 - Pindorama, instrumento coletivo de Walter Smetak em concerto regido por Ernst Widmer em 1969. Foto: Acervo da Associação de Amigos de Walter Smetak. . . . . . . . . . . . . . . 38

Figura 5 - Oficina de Guimarães, com alguns instrumentos utilizados pelo grupo Uakti. Foto: Acervo Uakti. . . . . . . . . . . . . . . . . . . . . . . . . . 40

Figura 6 - Nicolas Collins e o sistema de Eletrônica movida a trombone. Foto: Acervo Nicolas collins. . . . . . . . . . . . . . . . . . 62

Figura 7 - Ruben Pagani e Mariana Carvalho em oficina na Marcenaria. Foto do autor. . . . . . . . . . . . . . . . . . 8 81

Figura 8 - Tato Taborda em performance com a Geralda, ao fundo vê-se Alexandre Fenerich. Foto: Tato Taborda. . . . . . . . . . . . . . . . 86

Figura 9 - Peixe, de Wilson Sukorski e José Wagner Garcia. Foto: Wilson Sukorski. 87 Figura 10 - Chico Machado e o Ritimifiqueitor. Foto: Chico Machado. . . . . . . 88

Figura 11 - Aparelhos sonoros de Chico Machado em exposição. Foto: Chico Machado. 89 Figura 12 - Objetos utilizados por Loop B em suas performances. Foto: Loop B. . . 90 Figura 13 - Fernando Sardo em sua oficina. Foto: Divulgação. . . . . . . . . . . . . 91

Figura 14 - Instalação sonora Sons Recicláveis, criada por Fernando Sardo para a Sabina Escola Parque do Conhecimento, espaço cultural da Prefeitura de Santo André, SP. Foto: Maria Juliana Moura. . . . . . . . . . . . . 92

Figura 15 - Dessintetizador, instrumento coletivo do Grupo Experimental de Música. Foto: Divulgação. . . . . . . . . . . . . . . . . . . . . . 93

Figura 16 - Tzim Tzum de Marco Scarassatti. Foto: Alan Victor Pimenta. . . . . 95

Figura 17 - Capacetes para deriva sonora de Marco Scarassatti, utilizados no festival Novas Frequências. Foto: Divulgação. . . . . . . . . . . . . . . . 95

Figura 18 - Interface de controle utilizada em RevistaHertz, de Eduardo Néspoli e Maju Martins. Foto: Eduardo Néspoli. . . . . . . . . . . . . . . . . . 97

Figura 19 - Módulos de circuitos construídos por Pan\&Tone. Foto: Acervo Cristiano Rosa. . . . . . . . . . . . . . . . . . . . . . . 98

Figura 20 - O Bolo de Noiva. Foto: Henrique Iwao. . . . . . . . . . . . . . . . . 99

Figura 21 - Torres feitas a partir de eixos Cardan, na marcenaria do Ruben. Foto do autor. . . . . . . . . . . . . . . . . . . 101

Figura 22 - Narva 1. Foto: André Damião Bandeira. . . . . . . . . . . . . . . . . . 102

Figura 23 - Narva 2. Foto: André Damião Bandeira. . . . . . . . . . . . . . . . 103 
Figura 24 - O Percussiomixer. Foto: Eloi Silvestre. . . . . . . . . . . . . . . . . 104

Figura 25 - O Polyradiotron. Foto: Eloi Silvestre. . . . . . . . . . . . . . 105

Figura 26 - Dupla de Telembaus construídos por Paulo Nenflídio. Foto: Galeria Fortes Vilaça. . . . . . . . . . . . . . . . . . . . . . . . . . 107

Figura 27 - Teclado sísmico construído por Paulo Nenflídio. Foto: Paulo Nenflídio.108

Figura 28 - O sintetizador Jolymod II. Foto: Arthur Joly. . . . . . . . . . . . . . 108

Figura 29 - O sintetizador Fantasmo. Foto: Arthur Joly. . . . . . . . . . . . . . 109

Figura 30 - Palmilhas e transmissor da interface vestível TumTá. Foto: Batebit. . 110

Figura 31 - Controlador Disque-som. Foto: Batebit. . . . . . . . . . . . . . . . . . 111

Figura 32 - As bonecas Jezebel Crackletoy e Rosemary do Brechó de Hostilidades Sonoras. Foto: BHS. . . . . . . . . . . . . . . . . . . . . 112

Figura 33 - Tony da Gatorra em sua casa em Esteio, com a gatorra no 12 . Foto: Acervo Tony da Gatorra. . . . . . . . . . . . . . . . . . . . . . . . 118

Figura 34 - Capa de Paz pra ti, lançado por volta de 1998 com as primeiras gravações de Tony da Gatorra. . . . . . . . . . . . . . . . . . . . . 120

Figura 35 - Eduardo Santos e Tony da Gatorra no programa College na TV, em 1998. Foto: Acervo Eduardo Santos. . . . . . . . . . . . . . . . . . . . . 121

Figura 36 - Capa da versão original do disco Só Protesto, distribuído pela Peligro em 2004. . . . . . . . . . . . . . . . . . . . . . 123

Figura 37 - A gatorra de pano, feita por Luísa Lovefoxxx para Tony. Foto: Acervo Tony da Gatorra. . . . . . . . . . . . . . . . . . . . . . . . . . . 124

Figura 38 - Gatorra $n^{\circ}$ 7, feita para Nick McCarthy. Foto: Graeme Ronald. . . . . . 126

Figura 39 - Gatorra $n^{0} 1$. Foto do autor. . . . . . . . . . . . . . . . . . . . 128

Figura 40 - Minigatorra $\mathrm{n}^{\circ} 6$ e Batucador nº 1 . Foto: Acervo Tony da Gatorra. . 130

Figura 41 - Gatorra n²6 com bateria de laptop acoplada. Na direita da foto vê-se uma adaptação para encaixar o corpo do microfone sem fio. Foto: Acervo Tony da Gatorra. . . . . . . . . . . . . . . . . . . . . . . . . . . . . . 131

Figura 42 - Bateria eletrônica SLICIE. Foto do autor. . . . . . . . . . . . . . . 133

Figura 43 - Circuito da bateria SLICIE, utilizando um circuito integrado. Foto do autor. . . . . . . . . . . . . . . . 136

Figura 44 - Circuito da gatorra $n^{\circ} 19$. Foto do autor. . . . . . . . . . . . . 137

Figura 45 - Detalhe da gatorra $n^{\circ} 3$ mostrando o sintonizador de televisão utilizado para regular a altura dos sons. Foto: Binho Miranda. . . . . . . . . . . 138

Figura 46 - Da esquerda para a direita: O autor com a gatorra $n^{\circ} 19$, Tony com a gatorra $\mathrm{n}^{\circ} 1$, Paulo Abraão com a gatorra $\mathrm{n}^{\circ} 18$ e a minigatorra $\mathrm{n}^{\circ} 7$, Thiago Babalu e Alexandre Porres com a gatorra n². Foto: Acervo Alexandre Porres.no . . . . . . . . . . . . . . . . . . . . . . 171 


\section{Lista de abreviaturas e siglas}

CI Circuito integrado

DIY Do-It-Yourself, ou "faça você mesmo" mais especificamente aplicado à construção de circuitos eletrônicos.

ENCUN Encontro Nacional de Compositores Universitários, desde 2016 Encontro Nacional de Criatividade Sonora.

GRM Groupe de Recherches Musicales

NIME Conferência New Interfaces for Musical Expression

NuSom Núcleo de estudos em sonologia da Universidade de São Paulo

USP Universidade de São Paulo

VHS Video Home System, sistema doméstico de gravação e reprodução de vídeo 



\section{Sumário}

Introdução $\ldots \ldots \ldots \ldots \ldots \ldots \ldots \ldots \ldots \ldots \ldots$

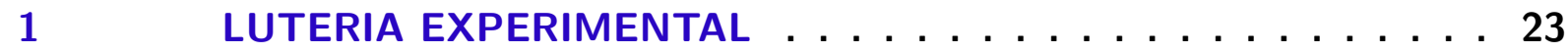

1.1 Terminologia e conceitos de instrumento . . . . . . . . . 23

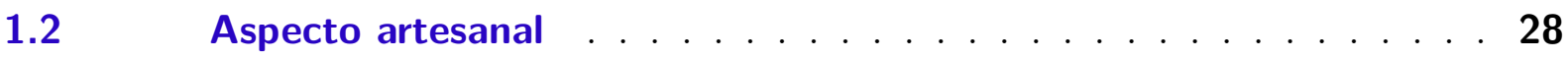

1.2 .1 Intonarumori . . . . . . . . . . . . . . . . . . . . . . . 29

1.2 .2 Irmãos Baschet . . . . . . . . . . . . . . . . . . . 31

$1.2 .3 \quad$ Harry Partch . . . . . . . . . . . . . . . 33

1.2.4 Walter Smetak . . . . . . . . . . . . . . . . . . . 35

1.2 .5 Marco Antônio Guimarães . . . . . . . . . . . . . . . . . . . . . . . . . 39

1.2.6 Patrick Ozzard-Low . . . . . . . . . . . . . . . . . . . . . 42

1.2.7 Bart Hopkin - Experimental Music Instruments . . . . . . . . . . . . 43

1.3 Readymade . . . . . . . . . . . . . . . . 43

1.3.1 O readymade industrial . . . . . . . . . . . . . . 48

1.3.2 Qubais Reed Ghazala . . . . . . . . . . . . . . . . . . . . . . 51

$1.4 \quad$ Modular . . . . . . . . . . . . . . . . . . . 52

1.4.1 Sintetizadores . . . . . . . . . . . . . . . . . 57

1.4.2 Música experimental . . . . . . . . . . . . . . . . . . . . . 59

$1.4 .3 \quad$ Luteria digital . . . . . . . . . . . . . . . . . 63

$1.5 \quad$ Pontos de análise $-1 \ldots \ldots \ldots \ldots$

2 CENA BRASILEIRA CONTEMPORÂNEA . . . . . . . 69

2.1 Referências . . . . . . . . . . . . . . . . 69

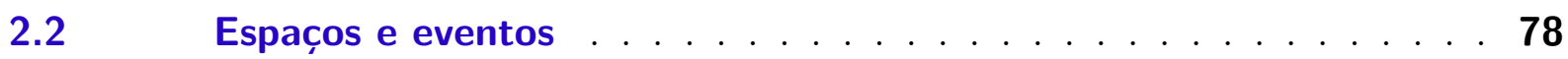

$2.2 .1 \quad$ Ibrasotope . . . . . . . . . . . . . . . . . 78

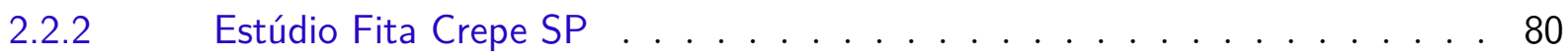

2.2.3 Instituto Volusiano de Artes Avançadas . . . . . . . . . . . . . . 80

2.2.4 Marcenaria do Ruben . . . . . . . . . . . . . . . . . . . . . . 80

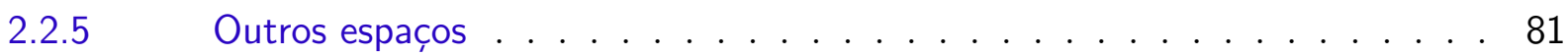

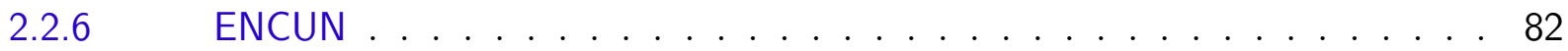

$2.2 .7 \quad$ Bloco Rú́do . . . . . . . . . . . . . . . . . . . 83

2.2.8 Panorama da Luteria Experimental . . . . . . . . . . . . . . . 83

2.2 .9 Outros eventos . . . . . . . . . . . . . . . . . . . . 84

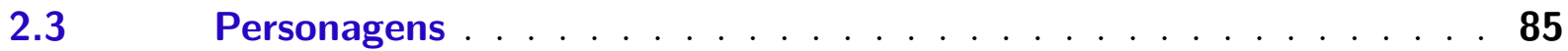

2.3.1 Tato Taborda . . . . . . . . . . . . . . . . . . . 85

2.3.2 Wilson Sukorski . . . . . . . . . . . . . . . . . . 86 
2.3.3 Chico Machado . . . . . . . . . . . . . . . . . . . . 87

2.3.4 Loop B . . . . . . . . . . . . . . . . . . . . . . . . . . . . 89

2.3.5 Fernando Sardo . . . . . . . . . . . . . . . . . . . 91

2.3.6 Marco Scarassatti . . . . . . . . . . . . . . . . . . . 93

2.3.7 Eduardo Néspoli . . . . . . . . . . . . . . . . . . . . . . 96

2.3.8 Pan\&Tone . . . . . . . . . . . . . . . . . . . 96

2.3.9 Marcelo Muniz . . . . . . . . . . . . . . . . . . . . . . . . . 98

2.3.10 Cadós Sanchez . . . . . . . . . . . . . . . . . . . . 100

2.3.11 André Damião Bandeira . . . . . . . . . . . . . . . . . . . 102

2.3.12 Eloi Silvestre . . . . . . . . . . . . . . . . . . . 103

2.3.13 Paulo Nenflídio . . . . . . . . . . . . . . . . . . 105

2.3.14 Arthur Joly . . . . . . . . . . . . . . . . . . 106

2.3.15 Batebit Artesania Digital . . . . . . . . . . . . . . 109

2.3.16 Brechó de Hostilidades Sonoras . . . . . . . . . . . . . . . . . . . . . 111

$2.4 \quad$ Pontos de análise $-2 \ldots \ldots$. . . . . . . . . . . . . . . . .

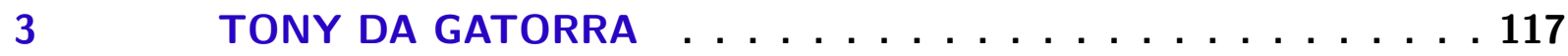

$3.1 \quad$ Biografia . . . . . . . . . . . . . . 117

$3.2 \quad$ Carcaça . . . . . . . . . . . . . . . . . 127

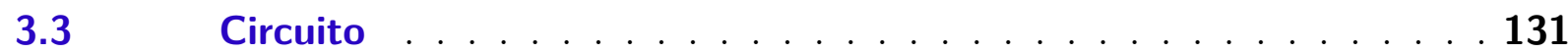

3.3.1 Drummer Boy e SLICIE . . . . . . . . . . . . . . . . . . . . 132

3.3.2 O circuito da gatorra . . . . . . . . . . . . . . 136

$3.4 \quad$ Pontos de análise $-3 \ldots \ldots$. . . . . . . . . . . . . . . . . . .

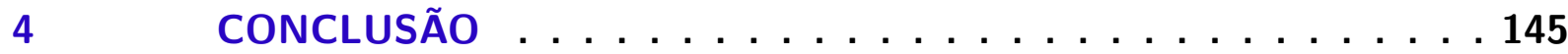

REFERÊNCIAS ....................... 159

$\begin{array}{ll}\text { APÊNDICES } & 167\end{array}$

APÊNDICE A - LEVANTAMENTO DE PRODUÇÃO - TONY DA GATORRA . . . . . . . . . . . . 169

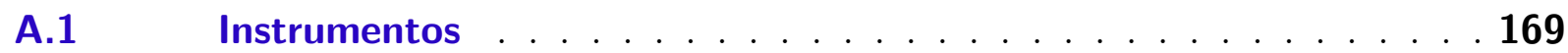

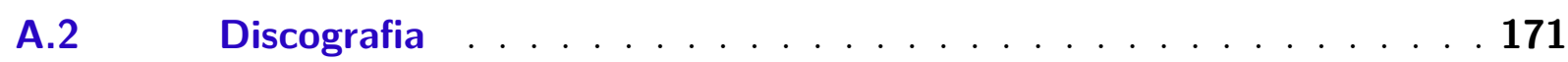

APÊNDICE B - ENTREVISTAS . . . . . . . . . 173

B.1 Construtores e artistas . . . . . . . . . . . . . 173

B.1.1 Chris Carter . . . . . . . . . . . . . . . . 173

B.1.2 Scott Lee - PAiA Electronics . . . . . . . . . . . . . . . 175 
B.1.3 George Romano . . . . . . . . . . . . . . . . . 176

B.1.4 Loop B . . . . . . . . . . . . . . . . . . . . . . . . . . . 180

B.1.5 Cadós Sanchez . . . . . . . . . . . . . . . . . . 183

B.1.6 Eloi Silvestre - Entrevista . . . . . . . . . . . . . . . . 186

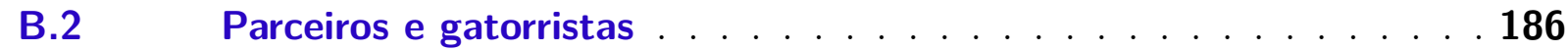

B.2.1 Eduardo Santos . . . . . . . . . . . . . . . . . . 186

B.2.2 Carlos Eduardo Miranda . . . . . . . . . . . . . . . . . 188

B.2.3 Dago Donato . . . . . . . . . . . . . . . . . . . 191

B.2.4 Binho Miranda . . . . . . . . . . . . . . . . . . . . . . 192

B.2.5 Graeme Ronald . . . . . . . . . . . . . . . . . . . . . . . . . 194

B.2.6 Marcelo Conter . . . . . . . . . . . . . . . . . . . . . . 195

B.2.7 Sérgio Pinto . . . . . . . . . . . . . . . . . . . 196

B.3 Entrevistas com Tony da Gatorra . . . . . . . . . . . . . . . . . . 198

B.3.1 21 de março de 2015 - Casa do Mancha . . . . . . . . . . . . . . . . . . 198

B.3.2 6 de maio de 2016 - Santa Ifigênia . . . . . . . . . . . . . . . . 201

B.3.3 18 de novembro de 2016 - Esteio . . . . . . . . . . . . . . . . 206

APÊNDICE C - MATERIAL COMPLEMENTAR . . . . . . . . 217

C.1 Registros em vídeo . . . . . . . . . . . . . . . 217

C.2 Outros artistas . . . . . . . . . . . . . . 218

C.3 Sítios de artistas e Luthiers . . . . . . . . . . . . . . . . . 220 



\section{Introdução}

Este trabalho é o resultado de uma pesquisa feita com artistas brasileiros que criaram instrumentos musicais experimentais, com maior ênfase na produção realizada nos últimos 20 anos e, em sua maioria, que ainda estão em atividade. Por praticidade e também por influência de outros autores, me refiro a este tipo de produção utilizando o termo Luteria Experimental, ainda que alguns dos artistas estudados neste trabalho tenham uma produção que se aproxima mais do conceito de arte sonora, realizada no espaço de galerias e exposições de arte, do que uma atividade de performance musical nos moldes tradicionais.

O que neste trabalho chamo de Luteria Experimental faz referência a um conjunto de práticas que constitui o processo de criação, modificação e adaptação de recursos para a produção musical de determinados repertórios. O termo em si não faz referência a um campo de estudos definido ou independente, mas constitui-se aqui uma pesquisa dentro do campo da sonologia que dialoga com trabalhos ligados a campos como a etnomusicologia, organologia, antropologia e sociologia, seja por meio do uso de referências originárias destes campos, seja pelo empréstimo de algumas de suas ferramentas metodológicas.

O ponto de partida desta pesquisa ocorre ao final de minha dissertação de mestrado, trabalho no qual eu foco na luteria em ambiente digital, e na criação de ferramentas e sistemas digitais pra performance musical. Ao final deste trabalho, me vi interessado em buscar um universo mais amplo de artistas que utilizassem técnicas e materiais diversos para construir seus instrumentos. Também desejava me aprofundar um pouco mais na produção de artistas que estariam naturalmente fora do universo pesquisado por mim no mestrado, por se tratarem de artistas que trabalhavam com eletrônica analógica ou construção de instrumentos acústicos.

Busquei um aprofundamento maior, dentro dos limites deste trabalho, em temas relacionados com a pesquisa. Logo nos primeiros estágios percebi que havia lacunas no que diz respeito a uma sistematização da bibliografia no tocante ao tema. Ainda que este não tenha sido o foco principal deste trabalho, acredito que nos capítulos 1 e 2 eu tenha colaborado neste sentido, a partir da constatação de que era necessário realizar um mapeamento, tanto do ponto de vista de referencias teóricas e relatos, quanto do ponto de vista de práticas que ocorrem no Brasil.

No capítulo 1 é feita uma discussão sobre o termo luteria experimental e sua aplicação neste trabalho, assim como é proposta a organização das tendências principais em quatro abordagens ou paradigmas, como forma de apresentar as principais referências bibliográficas deste campo, e também mapear o cenário de forma mais ampla. 
O capítulo 2 busca levantar referências anteriores à produção no Brasil e também realizar um mapeamento de artistas, espaços e eventos relacionados. Neste capítulo em especial busco articular meu trabalho de pesquisa com outros trabalhos realizados no contexto do grupo de pesquisas NuSom / USP e com outros pesquisadores atuantes no campo da Sonologia no Brasil. Sobre a escolha de artistas neste capítulo e no seguinte, busquei enfatizar a pesquisa e as discussões com relação à produção de instrumentos fora do ambiente digital. Em um primeiro momento, o trabalho buscava atravessar a fronteira da construção de instrumentos no ambiente digital e no físico, mas gradualmente à medida que a pesquisa foi se desenvolvendo, os contornos para focar na construção de dispositivos físicos, começaram a se delinear.

O capítulo 3 descreve a produção de um instrumento específico, a gatorra, criada e produzida por Antônio Carlos Correa de Moura, o Tony da Gatorra, técnico em eletrônica, artesão e músico residente em Esteio, no Rio Grande de Sul. No capítulo 4 eu analiso a produção pesquisada ao longo dos capítulos anteriores a partir de alguns referenciais teóricos, muitos deles de autores da Antropologia. Esta é uma escolha que denuncia minha iniciação em pesquisa acadêmica no campo da Etnomusicologia, mas de todo modo objetivo deste trabalho não é fazer uma análise destes instrumentos pelo ponto de vista da antropologia, mas argumentar que algumas ferramentas originárias da antropologia e da história da ciência que podem ser utilizadas para olhar para este tema dentro de estudos em Sonologia. Encerro cada capítulo com uma conclusão pontual, recapitulando os pontos que acredito serem mais importantes naquele capítulo para o desenvolvimento do texto.

Além da pesquisa bibliográfica e de registros em áudio e vídeo, realizei entrevistas com alguns dos artistas aqui estudados. Houve uma tentativa de contactar todos, mas por diversos motivos vários dos artistas aqui mencionados não chegaram ser entrevistados. As entrevistas foram feitas em meios diferentes de comunicação, sempre ficando facultado ao entrevistado escolher qual o método preferido, uma transcrição completa de todas as entrevistas feitas encontra-se no Apêndice B, com exceção de alguns trechos da entrevista com George Romano, que não conseguiram ser registrados para posterior transcrição, e da entrevista com Arthur Joly, cujo áudio original não ficou registrado devido a um cartão de memória defeituoso. 


\section{Luteria experimental}

Como mencionado na introdução, o campo da luteria experimental não é um campo claramente delimitado, sendo aqui considerado como um encontro de práticas e abordagens que fazem parte de outros nichos ou gêneros musicais e artísticos. O termo luteria experimental em si é potencialmente problemático e, antes de aprofundar as questões relativas ao presente trabalho, desenvolvo uma breve discussão sobre a escolha deste termo, seu uso no contexto utilizado e a definição que será utilizada neste texto. Como forma de organizar a pesquisa bibliográfica sobre as referências em termos de construção de instrumentos que norteia esta pesquisa, nas seções 1.2, 1.3 e 1.4 organizo estas referências de acordo com aspectos distintos que caracterizam estas produções:

- O aspecto Artesanal, em que o processo de criação, a partir de matérias-primas ou da modificação física de objetos existentes, segue uma orientação oriunda de práticas tradicionais de construção, luteria tradicional, e manejo destes meios;

- O aspecto de Readymade possui relação com o reaproveitamento, ressignificação e modificação de objetos sonoros já existentes;

- O aspecto Modular se relaciona com uma mudança de paradigma na construção de instrumentos musicais a partir das possibilidades ofertadas pela eletricidade, eletrônica analógica e digital.

Creio ser importante ressaltar neste ponto que o objetivo de propor estas classificações não é criar um sistema definitivo para abordagens em luteria experimental, mas tão somente facilitar o acesso a um universo vasto de práticas artísticas. Esta classificação não segue necessariamente uma ordem histórica, nem tampouco este componente histórico é fundamental para entender suas interconexões uma vez que existem, naturalmente, vários pontos de intersecção e confluência entre os três grupos. Não me proponho aqui a esgotar as discussões a respeito destas referências e dos temas abordados por seus autores.

\subsection{Terminologia e conceitos de instrumento}

O termo luteria é definido como "fabricação de instrumento de corda com caixa de ressonância", e também como "conjunto de tais instrumentos" pelo Novo dicionário Aurélio da língua portuguesa (2009), que sugere o uso deste segundo termo no lugar de luteraria. O dicionário Houaiss (2010, p. 1794) apresenta o termo luteria como sinônimo de luteraria e do termo em francês, lutherie, para o qual apresenta a definição "arte ou profissão de luthier; conjunto de instrumentos fabricados pelo luthier; oficina, fábrica 
ou loja de instrumentos musicais de cordas; comércio de luthier" ${ }^{1}$. Sobre a etimologia do termo, a mesma obra aponta a origem no termo francês lutherie, e o primeiro uso do termo datado de 1767. Já o termo luthier é definido como "profissional especializado na construção e no reparo de instrumentos de corda com caixa de ressonância (guitarra, violino etc.), mas não daqueles dotados de teclado", datado de 1649, também com origem no termo francês, que por sua vez deriva de $l u t h$, termo para "alaúde" . Dicionários de termos musicais como os de Sinzig (1959, p. 351) e Larousse (1999, p. 509) possuem definições semelhantes ${ }^{3}$.

Marques (1986, p. 316) registra a correspondência com os termos "Violeiro" e "Guitarreiro" em português, "Liutaio" em italiano, e "Geigenbauer, Lautenmacher e Gitarenbauer" em alemão, e ainda Borba \& Lopes Graça (1963, p. 152) registra a permanência do uso do termo violeiro para designar construtor de instrumentos de corda em português, principalmente em Portugal. Este uso do termo violeiro, assim como guitarreiro é observado também nos dicionários Aurélio (2009) e Houaiss (2010), onde também aparecem as definições de flautineiro como "fabricante de flautins". Dicionários como o Grove (1954, p. 447), Dourado (2004) e Borba \& Lopes Graça (1963, p. 152) já incluem em sua definição de luthier - e, por conseguinte, luteria - o sentido mais amplo de "uso geral para construção de instrumentos"4.

É neste último sentido em que os termos luthier e luteria são comumente usados no contexto da construção de instrumentos de forma experimental, independente da natureza de sua construção ou mesmo de ser ou não um instrumento físico, como é o uso feito por Battier (1995), Jordà (2004, 2005), Obici (2014), Ribeiro (2004) e Scarassatti (2008), entre diversos autores. Já o termo luteria experimental é utilizado por Fernandez (2013, p. 8), Fernando Sardo (ao descrever sua produção, em seu website <http://www.fernandosardo. com.br/portugues $/>^{5}$ ), Ribeiro (2004), entre outros.

É importante destacar, para os fins desta pesquisa, que o emprego do termo luteria para designar um processo de construção de instrumentos está associado com algum conceito estruturante de instrumento musical. Para abordar esta questão, opto aqui por utilizar o trabalho sobre diferentes métodos de classificação instrumental de Kartomi (1990) como referência sobre como o conceito de instrumento muda ao longo dos tempo e em diferentes contextos culturais. É comum na organologia ocidental partir-se do pressuposto de que o mesmo conceito estruturante de instrumento musical - no caso, o ocidental -

1 Nota do autor: itálicos no original

2 Não foi encontrada nenhuma referência aos termos luthier, luthierie e luteria nos dicionários etimológicos de José Pedro Machado (1987), Antenor Nascentes (1966) e Cunha (2010)

3 Todas as traduções, exceto quando notado, são de responsabilidade do autor.

4 Uma grafia alternativa do termo, luthieria, tem se observado recentemente em associação aos serviços de reparos, ajustes e também construção de instrumentos como guitarras e contrabaixos elétricos. Disponível em: <http://www.luthieriabrasil.com.br/>, <http://wgluthier.wixsite.com/nwgabriel>, <http://www.soluthier.com.br/>. Acesso em 28 de agosto de 2017.

5 Acesso em 10 de fevereiro de 2018 
norteia a práxis musical em diferentes contextos históricos, geográficos e sociais. Kartomi postula que o conceito de instrumento está integrado a conceitos mais amplos, como os conceitos de música, conhecimento do cosmos ou mesmo da existência humana ${ }^{6}$. Como será visto mais adiante, o conceito de instrumento na obra de criadores como Harry Partch e Walter Smetak, por exemplo, está intimamente associado a conceitos mais abrangentes e conectados a um projeto maior de expansão da consciência humana. Sobre o que chama de conceito de instrumentos, a autora afirma:

A expressão conceito de instrumentos faz referência à visão dominante ou visões concorrentes, em uma sociedade, do sentido e significado de instrumentos como fenômeno cultural, incluindo-se aí as classificações hierárquicas dos instrumentos ${ }^{7}$.

A partir do levantamento de Kartomi, observo que conceitos historicamente mais antigos, em geral, estão relacionados com a espiritualidade e com o entendimento de universo vigente em uma determinada sociedade, vide o conceito chinês de instrumentos como manifestação das forças da natureza e seus elementos ${ }^{8}$, ou com a associação entre instrumentos e manifestações de deidades, como no subcontinente indiano e no sudoeste asiático $^{9}$. Também são muito comuns, em contextos historicamente mais antigos, conceitos e descrições antropomórficas, estabelecendo paralelos entre partes dos instrumentos e partes do corpo humano ${ }^{10}$.

Na cultura helênica surge um conceito de instrumento musical inédito até então: o instrumento como recurso técnico-científico, para observar relações matemáticas e pesquisas em acústica, principalmente através do uso da corda tensionada ${ }^{11}$, diferindo desta forma de sociedades que operam a partir de conceitos relacionados com sua cosmogênese ou com conceitos antropomórficos ${ }^{12}$. Este olhar científico sobre o instrumento musical estabelece no ocidente os primórdios de uma tradição de pesquisas em acústica musical com base em instrumentos musicais, mas é importante destacar que mesmo no contexto da cultura helênica existe uma diferenciação entre o instrumento sonoro / musical de caráter científico e instrumentos musicais utilizados na prática musical ${ }^{13}$. Estes, em alguma medida, também são associados às características de deidades, como a associação da lira e da kithara a Apolo, e dos instrumentos de sopro como o aulos a Dionísio ${ }^{14}$.

6 (KARTOMI, 1990, p. xv)

7 (KARTOMI, 1990, p. xv)

8 (KARTOMI, 1990, p. 50)

9 (KARTOMI, 1990, p. 57). Neste contexto é importante citar que a mais antiga classificação indiana conhecida, parte do tratado Natya Shastra, também leva em consideração o princípio de produção de sonora dos instrumentos como elemento classificatório.

10 (KARTOMI, 1990, p. 105)

11 (KARTOMI, 1990, p. 108)

12 (KARTOMI, 1990, p. 108)

13 (KARTOMI, 1990, p. 115-116)

14 (KARTOMI, 1990, p. 111) 
Outra distinção relativa a instrumentos musicais que surge neste período e que perdurou historicamente é observada entre instrumentos musicais inanimados, por assim dizer, e o corpo humano, com uma importância maior conferida à voz humana, tanto em relação aos demais sons emitidos pelo corpo humano quanto sobre os demais instrumentos ${ }^{15}$. Esta distinção conceitual é feita por Aristóteles por meio dos termos organon psychon, instrumentos animados ou dotados de alma, e organon apsychon, instrumentos inanimados, onde o termo organon é utilizado no sentido de "aparato mecânico"16. Sobre esta distinção Kartomi afirma que tradicionalmente, na organologia, o corpo humano e a voz não são considerados como instrumentos musicais em si, ainda que Sachs (1940, p. 26) proponha a hipótese de que instrumentos de percussão rudimentares tenham eventualmente surgidos como desenvolvimento de gestos como o bater de palmas e pisadas no chão, e a adição de uma categoria de corpofones à taxonomia Hornbostel-Sachs ${ }^{17}$ tenha sido proposta por Dale Olson em $1985^{18}$.

Ao longo da Idade Média a natureza do instrumento musical não é tão significativa como objeto técnico, mas como simples ferramenta para produzir música que, em última instância, deve servir à obra divina ${ }^{19}$. Kartomi destaca que ao longo da Renascença um conceito humanista de instrumento começa a surgir, e que a partir do século XIV

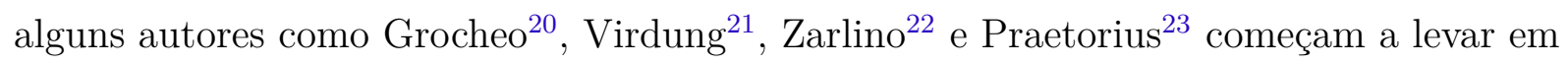
consideração a prática musical não-eclesiástica em seus textos, assim como os instrumentos utilizados nesta prática ${ }^{24}$.

Esta concepção humanista de instrumento é o primeiro passo na consolidação de um conceito de instrumento musical a-histórico e secular que orienta os primeiros estudos da organologia contemporânea, como exemplificado na taxonomia de Mahillon ${ }^{25}$, desenvolvida em 1893 e posteriormente adaptada por Hornbostel-Sachs em $1914^{26}$. Neste contexto, o

15 (KARTOMI, 1990, p. 108-109)

16 (KARTOMI, 1990, p. 109)

17 (HORNBOSTEL; SACHS, 1961, p. 553-590)

18 (KARTOMI, 1990, p. xviii)

19 (KARTOMI, 1990, p. 139)

20 Johannes de Grocheo (c. 1255 - c. 1320), teórico musical parisiense autor do tratado Ars musicae (c. 1300). Disponível em: < https://en.wikipedia.org/wiki/Johannes_de_Grocheio>. Acesso em 26 de agosto de 2017.

21 Sebastian Virdung (nascido c. 1465), teórico e compositor alemão, autor do tratado Musica gesuscht und angezogen, de 1511, considerado a fonte impressa mais antiga com descrições de instrumentos musicais. Disponível em: < https://en.wikipedia.org/wiki/Sebastian_Virdung>. Acesso em 26 de agosto de 2017.

22 Gioseffo Zarlino (1517 - 1590), teórico e compositor italiano, autor de um tratado com descrição de instrumentos contemporâneos em 1588(KARTOMI, 1990, p. 151).]

23 Michael Praetorius (1517 - 1621), teórico, compositor e organista alemão, autor do Syntagma Musicum, tratado publicado entre 1614 e 1620. Disponível em: < https://en.wikipedia.org/wiki/Michael_ Praetorius $>$. Acesso em 26 de agosto de 2017.

24 (KARTOMI, 1990, p. 135-161)

25 Victor-Charles Mahillon (1814 - 1924), músico, autor e construtor de instrumentos belga, foi o fundador do atual Museu de Instrumentos Musicais de Bruxelas. Disponível em: < https://fr.wikipedia.org/wiki/ Victor-Charles_Mahillon>. Acesso em 27 de agosto de 2017.

26 (KARTOMI, 1990, p. 163) 
instrumento musical é considerado como objeto musicalmente funcional, levando-se em conta principalmente o seu aspecto morfológico ${ }^{27}$. Hornbostel e Sachs, ao introduzirem seu sistema, apontam para a contradição entre o aspecto "vivo e dinâmico" de seus objetos de estudo e as necessidades impostas pela criação de sistemas de classificação ${ }^{28}$. A proposta de criar um sistema que dê conta de classificar instrumentos musicais de todas as "épocas e nações" 29 , no entanto, revela a perspectiva eurocêntrica de um conceito de instrumento ideal, a-histórico e transcultural.

Apesar de ser alvo de diversas críticas, o sistema Hornbostel-Sachs de classificação instrumental - assim como o conceito de instrumento associado a este sistema - ainda é o método mais amplamente utilizado em áreas como a musicologia, a etnomusicologia, a organologia, assim como na organização de acervos de coleções e museus. Fora destes contextos, ainda prevalece a classificação tradicionalmente herdada da orquestra sinfônica, classificando instrumentos musicais em cordas, sopros e percussão ${ }^{30}$. Além do sistema Hornbostel-Sachs, dois sistemas de classificação instrumental propostos por Galpin ${ }^{31} \mathrm{em}$ 1910 e $1937^{32}$, um esquema proposto por Schaeffner ${ }^{33}$ em $1932^{34}$, Montagu e Burton em $1971^{35}$ e Sakurai em $1981^{36}$ se baseiam num conceito de instrumento semelhante, com finalidades de classificação universal de instrumentos musicais.

Ainda segundo Kartomi ${ }^{37}$ um distanciamento gradual do conceito morfológico de instrumento, no campo da organologia, tem início a partir de um artigo escrito por Norlind ${ }^{38}$ em 1932, no qual é proposta uma visão dinâmica e expansiva do instrumento musical como parte de comportamentos musicais e socio-históricos. Autores diversos ${ }^{39}$ levam estes fatores em consideração no desenvolvimento de sistemas de classificação instrumental, ou em expansões de sistemas já existentes que levem em conta demais fatores além dos fatores morfológicos e baseados na produção sonora de sistemas mais tradicionais.

Esta visão dinâmica e expansiva do instrumento musical vai de encontro com a

27 (KARTOMI, 1990, p. 169)

28 (HORNBOSTEL; SACHS, 1961, p. 4)

29 (HORNBOSTEL; SACHS, 1961, p. 5)

30 (KARTOMI, 1990, p. 171)

31 Francis William Galpin (1858-1945), clérigo, colecionador de instrumentos musicais antigos e musicólogo britânico. Disponível em:<https://en.wikipedia.org/wiki/Francis_William_Galpin>. Acesso em 13 de setembro de 2017.

32 (KARTOMI, 1990, p. 165-167, 176-177)

33 André Schaeffner (1895-1980), antropólogo e etnomusicólogo francês. Disponível em: $<$ https://fr. wikipedia.org/wiki/André_Schaeffner>

34 (KARTOMI, 1990, p. 174-176)

35 (KARTOMI, 1990, p. 183-184)

36 (KARTOMI, 1990, p. 191-193)

37 1990, p. 177

38 Tobias Johan Henrik Norlind, (1879-1947), musicólogo e diretor do Museu de História Musical de Estocolmo. Disponível em:<https://de.wikipedia.org/wiki/Tobias_Norlind $>$. Acesso em 13 de setembro de 2017

39 Como Izikowitz (1935), Dräger (1947, 1957), Reihard (1960), Hood (1971), Ramey (1974), Malm (1974), Heyde (1975), Hartmann (1978) e Lysloff \& Matson (1985). 
tendência cultural no ocidente de tentar organizar instrumentos do modo mais lógico possível:

Ao adotarmos um conceito de instrumentos que leve em consideração não só sua propensão em mudar ao longo do tempo mas também a profundidade de seu significado musical e cultural, o distanciamento de uma divisão lógica estrita é no mínimo esperado. Normalmente esquemas perfeitamente lógicos não correspondem à complexidade da prática musical ${ }^{40}$.

Um bom exemplo destas limitações é a categoria dos eletrofones, que surge inicialmente no segundo sistema de Galpin em $1937^{41}$ e é acrescida como um adendo ao sistema Hornbostel-Sachs a partir de $1940^{42}$, fazendo parte de outros sistemas como o de Dräger em $1947^{43}$. A categoria é proposta para acomodar os instrumentos eletroeletrônicos que começam a surgir a partir da primeira metade do século XX, e Kartomi (1990, p. 174) destaca artigos de Moorer e de Risset \& Wessel que utilizam a classificação Hornbostel-Sachs para descrição de instrumentos eletrônicos e digitais. Ainda que revisões mais recentes do sistema Hornbostel-Sachs, como a feita pelo consórcio MIMO (2011, p. 21-24) dêem conta de uma grande variedade de formas eletroeletrônicas e digitais de produzir e processar sons, para os fins desta pesquisa uma abordagem baseada meramente no princípio de produção sonora se mostra relativamente limitada para lidar com um conceito de instrumento em transição.

\subsection{Aspecto artesanal}

O que chamo aqui de aspecto artesanal na luteria experimental está relacionado com práticas de construção de instrumentos que envolvam a aplicação de técnicas tradicionais de manejo de matérias-primas com paralelos na luteria tradicional, e em outras atividades artesanais baseadas na construção manual de instrumentos.

Uma influência muito presente no trabalho dos criadores relacionados nesta seção é a obra Das Sensações do Tom como uma Base Fisiológica para a Teoria da Música, de Hermann Von Helmholtz (1954), publicada inicialmente em 1862 e com 4 edições lançadas até $1877^{44}$. À segunda tradução para o inglês - feita em 1885 com base no texto de 1877 - Alexander J. Ellis acrescentou um vasto apêndice sobre temperamentos, afinações e construção de escalas que também teve vasta influência na produção aqui $\operatorname{descrita}^{45}$.

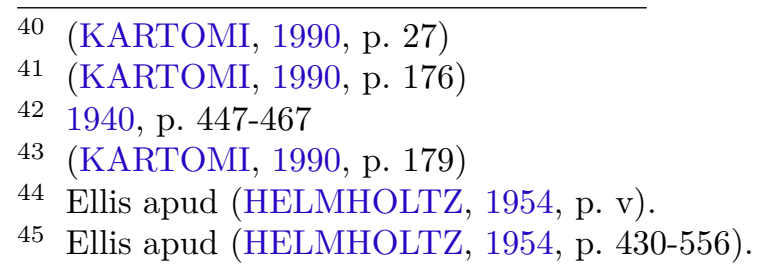




\subsubsection{Intonarumori}

Ribeiro (2004, 23-24) e Obici (2014, p. 112), reconhecem no trabalho do italiano Luigi Russolo (Portogruaro, 1885 - Bottanuco, 1947) um primeiro exemplo de luteria experimental na contemporaneidade com foco na busca de sonoridades pouco ortodoxas. O trabalho de Russolo mais conhecido neste sentido são os Intonarumori, instrumentos criados com o objetivo de viabilizar as ideias de Russolo sobre uma música futurista, construídos em parceria com Ugo Piatti a partir de $1913^{46}$. A produção de Russolo e Piatti é a materialização das ideias expostas por Russolo no ensaio "A arte dos ruídos"47, publicado em 11 de março de 1913, em que o autor propõe uma organização de seus entoadores de ruído em 6 famílias ${ }^{48}$ e a adoção, no repertório musical ocidental, da "infinita variedade dos sons-ruído" 49 .

O manifesto original de 1913 é acrescido de demais textos em um volume editado em 1916, também intitulado L'Arte dei rumori ${ }^{50}$, no qual Russolo amplia consideravelmente a teoria musical sob a perspectiva do Futurismo. Este texto é reeditado em 1986 com tradução para o inglês do compositor estadunidense Barclay Brown, também autor de uma introdução ao volume com dados biográficos sobre Russolo ${ }^{51}$ e algumas informações sobre outros instrumentos construídos após 1916, como é o caso de quatro versões do Rumorarmonio - um instrumento que consistia na reunião de diferentes intonarumori sob o controle de um único intérprete - construídas entre 1924 e 1928 52 , um Arco Enarmônico feito para tocar de forma alternativa instrumentos de corda tradicionais e dessa forma obter novos timbres ${ }^{53}$, e o projeto de um Piano Enarmônico, nunca construído. Brown destaca também que partes de um modelo deste último instrumento são os únicos materiais sobreviventes de todo o instrumental construído e idealizado por Russolo e Piatti ${ }^{54}$ que, especula-se, tenha desaparecido no fim da Segunda Guerra Mundial em $1945^{55}$. Brown também complementa a descrição de Russolo sobre os diferentes tipos de intonarumori, acrescentando mais três tipos a uma lista de nove descrita por Russolo ${ }^{56}$, e complementando as descrições de Russolo sobre seus modos de funcionamento.

Considero importantes também dois pontos destacados por Brown em sua introdução. O primeiro é o pioneirismo de Russolo ao propor uma música que abrace as sonoridades e ruídos do mundo contemporâneo, sem dúvida uma grande influência em diversas práticas

46 (RUSSOLO, 1986, p. 32)

47 (RUSSOLO, 1986, p. 23-30)

48 (RUSSOLO, 1986, p. 28)

49 (RUSSOLO, 1986, p. 25)

50 (RUSSOLO, 1986)

51 Brown apud (RUSSOLO, 1986, p. 1-21)

52 Brown apud (RUSSOLO, 1986, p. 7-8)

53 Brown apud (RUSSOLO, 1986, p. 13)

54 Brown apud (RUSSOLO, 1986, p. 10)

55 (CHESSA, 2014, p. 150)

56 (RUSSOLO, 1986, p. 75) 
musicais do século XX, ainda que o acesso direto aos textos originais de Russolo tenha sido limitado $^{57}$ e que, em grande parte, a influência de Russolo nas gerações seguintes tenha se dado inicialmente através da influência que o próprio Russolo teve no Dadaísmo ${ }^{58}$.

O segundo é o fato de que Russolo não teve formação musical e não há registros de qualquer atividade musical até o seu envolvimento com o Futurismo italiano em 1910, movimento ao qual se juntou como artista plástico, ainda que não tivesse tido, tampouco, um aprendizado formal no campo das artes plásticas. É através do ímpeto Futurista, de suas próprias hipóteses e da construção de um instrumental que Russolo vem a se tornar músico $^{59}$.

Chessa (2014, p. 148) destaca o interesse e influência dos futuristas pela Teosofia ${ }^{60}$, por via do Simbolismo francês. Esta influência da Teosofia, assim como um interesse particular pela obra de Leonardo da Vinci, segundo Chessa, confere aos intonarumori uma dimensão de instrumento filosófico-científico nos moldes do monocórdio pitagórico ${ }^{61}$, como parte de um ambicioso projeto metafísico.

Além de investigar as relações do Futurismo italiano e de Luigi Russolo com o ocultismo, Chessa também empreendeu a construção de réplicas dos intonarumori juntamente com o luthier estadunidense Keith Cary entre 2008 e 2009 ${ }^{62}$, sob encomenda do festival Performa ${ }^{63}$. Além dos poucos documentos de referência sobre a construção dos instrumentos deixadas por Russolo ${ }^{64}$, Chessa e Cary também utilizaram como referência projetos anteriores de reconstrução dos intonarumori como o realizado por Pietro Verardo para a Bienal de Veneza de $1977^{65}$.

O trabalho de Chessa revela uma nova perspectiva sobre a produção de Russolo, e sobre o Futurismo italiano, ao apontar suas relações com a Teosofia e sociedades de estudos ocultistas e espiritualistas do séc. XIX, um aspecto deste movimento artístico que nem sempre é discutido. Russolo e os intonarumori sem dúvida são um ponto de referência

57 Brown apud (RUSSOLO, 1986, p. 1)

58 Brown apud (RUSSOLO, 1986, p. 20)

59 Brown apud (RUSSOLO, 1986, p. 3)

60 Nota do autor: neste caso em particular, fala-se da Teosofia como praticada pela Sociedade Teosófica fundada em 1875 por Helena Blavatsky, Henry Olcott e William Judge em Nova Iorque. Informações sobre a Sociedade Teosófica disponíveis em: <https://en.wikipedia.org/wiki/Theosophy $>$. Acesso em 30 de setembro de 2017.

61 (CHESSA, 2014, p. 149)

62 Disponível em: <http://www.keithcary.com/Keith\%20Cary/Experimental\%20Instuments, \%20Intonarumori.html $>$. Os instrumentos construídos por Chessa e Cary podem ser vistos neste vídeo: <https://www.youtube.com/watch?v=Lqej96ZVoo8>. Acesso em 30 de setembro de 2017.

63 Disponível em: <http://performa-arts.org/do-not-enter-or-modify-or-erase/client-uploads/pdf/ IntonarumoriTouringInfo.pdf $>$. Acesso em 5 de abril de 2018.

64 Brown apud (RUSSOLO, 1986, p. 10)

65 Além da reconstrução de Verardo, Chessa (2014, p. 151) também menciona um projeto realizado no Japão e outro na Holanda, sem detalhar a época de sua realização. Um dos instrumentos construídos por Verardo pode ser visto neste vídeo: < https://www.youtube.com/watch?v=uDc6g8L-PjE $>$. Acesso em 30 de setembro de 2017 
importante na medida em que o instrumental criado é a materialização de uma teoria musical que contrasta com o cânone da música ocidental, mas que também busca formas diferentes de integração entre teoria e prática musical e outros aspectos mais abrangentes de uma visão de mundo. Este é um modelo que se manifesta também na obra de outros criadores que menciono mais adiante neste trabalho.

\subsubsection{Irmãos Baschet}

A pesquisa e produção dos irmãos Bernard e François Baschet ${ }^{66}$ tem início a partir dos anos 1950, em Paris ${ }^{67}$. O cerne de sua pesquisa é a busca de formas de produção sonora pouco usadas por instrumentos convencionais, a partir de um levantamento morfológico minucioso feito pelos irmãos Baschet ainda no começo de sua produção.

O trabalho dos irmãos Baschet começa a ser desenvolvido em Paris justamente na época em que florescem, na mesma cidade, as primeiras obras e equipamentos voltados para a produção de música concreta. Segundo François Baschet, todos os estudos em acústica musical da época eram voltados para a eletrônica e eletroacústica ${ }^{68}$, e um estudo voltado para o construção de instrumentos acústicos teve de ser desenvolvido de forma independente, ainda que a teoria e os métodos desenvolvidos pela nascente música eletroacústica, em especial a música concreta, tenham sido absorvidos em sua pesquisa e construção de instrumentos, sobretudo a partir da experiência de Bernard Baschet junto ao GRM ${ }^{69}$. É desse período a definição de instrumento que orienta a criação do instrumental Baschet, segundo a qual um instrumento musical consiste na junção de pelo menos três dos itens a seguir $^{70}$ :

- Um elemento que produza uma vibração periódica;

- Uma forma de energia que ative esta vibração;

- Um aparato para implementar a escala;

- Um amplificador de som;

- A estes quatro elementos François propõe a soma de um quinto, o uso de ressoadores simpáticos adicionais ${ }^{71}$.

Através da associação com o casal Jacques e Yvonne Lasry, os primeiros concertos com instrumentos criados pelos irmãos, então chamados de Estruturas Sonoras Lasry-

66 Nascidos em 1917 e 1920, falecidos em 2015 e 2014, respectivamente, em Paris. Disponível em: <https://en.wikipedia.org/wiki/Baschet_Brothers>. Acesso em 02 de outubro de 2017.

67 (BASCHET, 1968, p. 398)

68 (BASCHET, 2017, p. 46).

69 (BASCHET, 1968, p. 398).

70 (BASCHET, 2017, p. 46)

71 (BASCHET, 2017, p. 47) 
Baschet, ocorrem em 1955. Sobre a classificação de suas obras, aquilo que os irmãos chamam de estruturas são "criações em que a sonoridade é a característica proeminente", enquanto que esculturas seriam as obras voltadas para exibição em galerias e museus, ainda que estas possuam uma dimensão sonora ${ }^{72}$.

O instrumental Baschet é orientado pelo interesse na forma do instrumento como elemento visual e tátil, associada às propriedades acústicas dos materiais e formas obtidas, mas também pelo ímpeto de desenvolver instrumentos cujo modo de funcionamento seja inovador, para os padrões de referência de seus criadores. Um interesse pela construção de instrumentos coletivos e que possam ser integrados ao espaço público também influencia o desenvolvimento deste instrumental, a partir de experiências em que o coletivo LasryBaschet convidava o público de suas apresentações a subir ao palco e interagir com seus instrumentos ${ }^{73}$, mas também em consonância com o movimento de arte cinética e de obras de artistas como Alexander Calder ${ }^{74}$. Segundo François Baschet ${ }^{75}$, suas preocupações criativas são sintetizadas da seguinte forma:

- Uma pesquisa estética no domínio sonoro;

- Uma pesquisa estética no domínio formal;

- Levar em conta a função social e as consequências da arte;

- A participação do público.

A partir dos anos 1960 Bernard Baschet começa a dedicar suas pesquisas e o desenvolvimento de instrumentos para a educação musical infantil" através da "Associacion Structures Sonores et Pédagogie", criada em 1982 por Bernard Baschet, atuando hoje em dia sob o nome Structures Sonores Baschet ${ }^{77}$.

A produção dos irmãos Baschet é inovadora no uso de materiais pouco comuns até então - como vidro, chapas de aço e ressoadores pneumáticos - e refletem um interesse na dimensão visual e tátil de suas obras que encontra paralelos na produção de outros criadores contemporâneos como Walter Smetak. Seu pensamento musical é igualmente influenciado pela inspiração técnico-científica das artes no pós-guerra, buscando paralelos na teoria da informação e nas ciências naturais ${ }^{78}$.

\footnotetext{
72 Disponível em: <http://francois.baschet.free.fr/story.htm>. Acesso em 01 de outubro de 2017

73 (BASCHET, 1968, p. 400)

74 (BASCHET, 1968, p. 401)

75 Disponível em: <http://www.baschet.org/structures/lesfreresbaschet.php>. Acesso em 01 de outubro de 2017.

76 Disponível em: <http://francois.baschet.free.fr/story.htm>. Acesso em 01 de outubro de 2017.

77 Disponível em: < http://www.baschet.org/association/quisommesnous.php>. Acesso em 01 de outubro de 2017

78 (BASCHET, 1968, p. 396)
} 


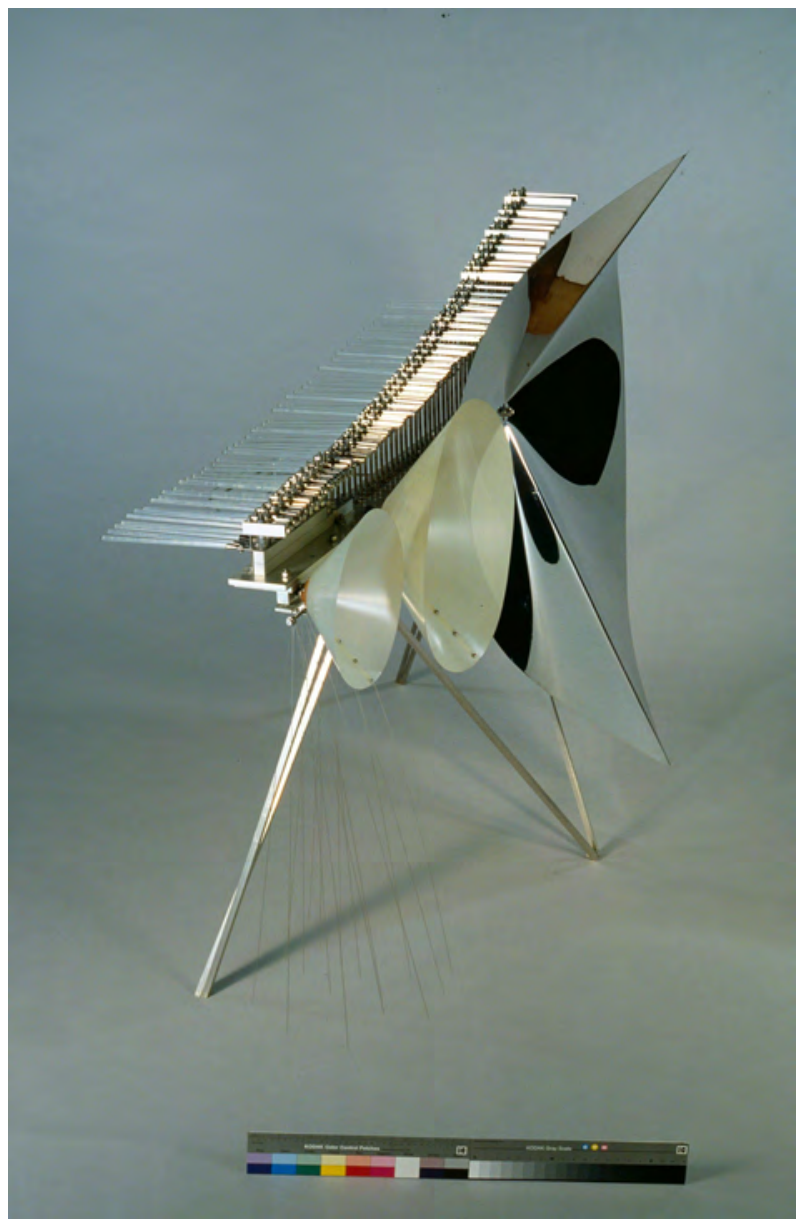

Figura 1 - Cristal Baschet. Foto: Jean-Marc Anglès para o Musée de la Musique.

\subsubsection{Harry Partch}

A introdução de Harry Partch (Oakland, 1901 - Encinitas, 1974) a repertórios musicais de outras culturas se deu ainda na infância, devido a vivência de seus pais como missionários na China, anterior a seu nascimento, e também pela proximidade com comunidades indígenas nativas dos estados do Arizona e Novo México, na região sudoeste dos Estados Unidos ${ }^{79}$. O encontro, aos 21 anos, com a obra de Helmholtz e Ellis é descrito por Partch como um momento de mudança radical em seu direcionamento criativo, influenciando suas primeiras obras escritas utilizando afinação justa em substituição à afinação temperada ${ }^{80}$, e estas primeiras pesquisas com afinação justa sugeriram a necessidade de desenvolver instrumentos construídos especificamente para este fim. No entanto, ainda que seu trabalho criativo envolva uma quantidade considerável de pesquisa e desenvolvimento de aspectos técnicos, este é um ponto secundário em relação à pesquisa composicional: 
Quando comecei a buscar respostas para os problemas de afinação, eu era um compositor. Ainda o sou, e cada ato musical meu é gerado partindo dessa premissa. Nenhuma proporção entre vibrações foi anotada e tampouco um pedaço de madeira colado a outro sem que seu objetivo último fosse a criação musical ${ }^{81}$.

O sistema de Partch é desenvolvido tendo a frequência de $392 \mathrm{~Hz}$ como diapasão - correspondendo à nota sol imediatamente abaixo do diapasão da nota lá em $440 \mathrm{~Hz}$ a partir da qual diferentes proporções dão origem a uma subdivisão não-temperada da oitava em 43 intervalos ${ }^{82}$. No tocante ao instrumental, Partch inicia seus experimentos com modificações de instrumentos existentes, como é o caso da Viola Adaptada, desenvolvida em 1930. Este instrumento consiste em uma viola de tamanho regular com braço e espelho aumentados em seis polegadas, afinada em quintas justas a partir de $98 \mathrm{~Hz}$, diapasão da corda mais grave e com marcações no espelho correspondentes a 29 subdivisões da oitava ${ }^{83}$.

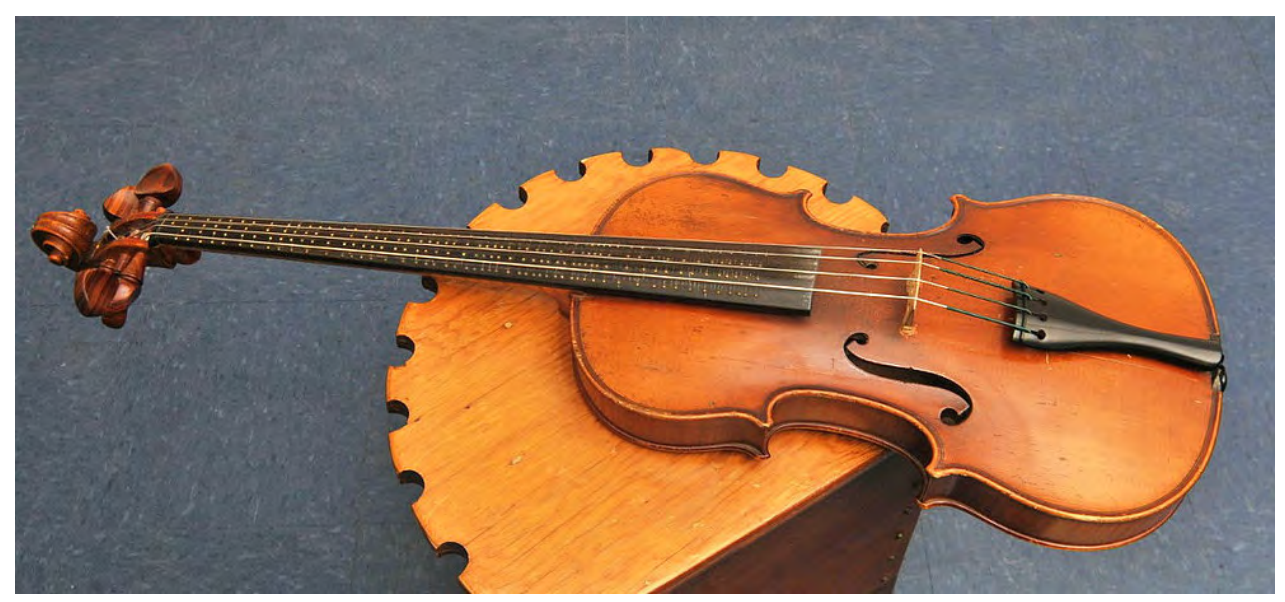

Figura 2 - Viola adaptada de Harry Partch.

No período entre 1934 e os anos 1950 alguns violões adaptados também foram desenvolvidos por Partch, mas sua adaptação mais longeva consiste num órgão de palhetas modificado para acomodar todas as 43 subdivisões da oitava - no espaço de três oitavas e meia de um teclado de órgão convencional, com as demais teclas à esquerda e à direita das 44 centrais afinadas de acordo com o sistema de Partch. Os dois órgãos adaptados entre 1945 e 1950, chamados por Partch de Chromelodeons, possuem uma dupla função podendo atuar como diapasão para afinar demais instrumentos, e também podendo ser usados em performance.

81 (PARTCH, 1974, p. xviii)

82 (PARTCH, 1974, p. 133). Levando-se em conta o uníssono - proporção $1 / 1$ - a sequência de proporções até a oitava - proporção $2 / 1$ - é $81 / 80,33 / 32,21 / 20,16 / 15,12 / 11,11 / 10,10 / 9,9 / 8,8 / 7,7 / 6,32 / 27$, $6 / 5,11 / 9,5 / 4,14 / 11,9 / 7,21 / 16,4 / 3,27 / 20,11 / 8,7 / 5,10 / 7,16 / 11,40 / 27,3 / 2,32 / 21,14 / 9,11 / 7$, 8/5, 18/11, 5/3, 27/16, 12/7, 7/4, 16/9, 9/5, 20/11, 11/6, 15/8, 40/21, 64/33, 160/81.

83 (PARTCH, 1974, p. 199-203) 
A partir dos anos 1950 a luteria de Partch se direciona para a construção de instrumentos projetados especificamente para seu sistema de afinação, em sua maioria idiofones de madeira ou vidro, e cordofones inspirados em instrumentos gregos e medievais, como o Saltério e a Kithara.

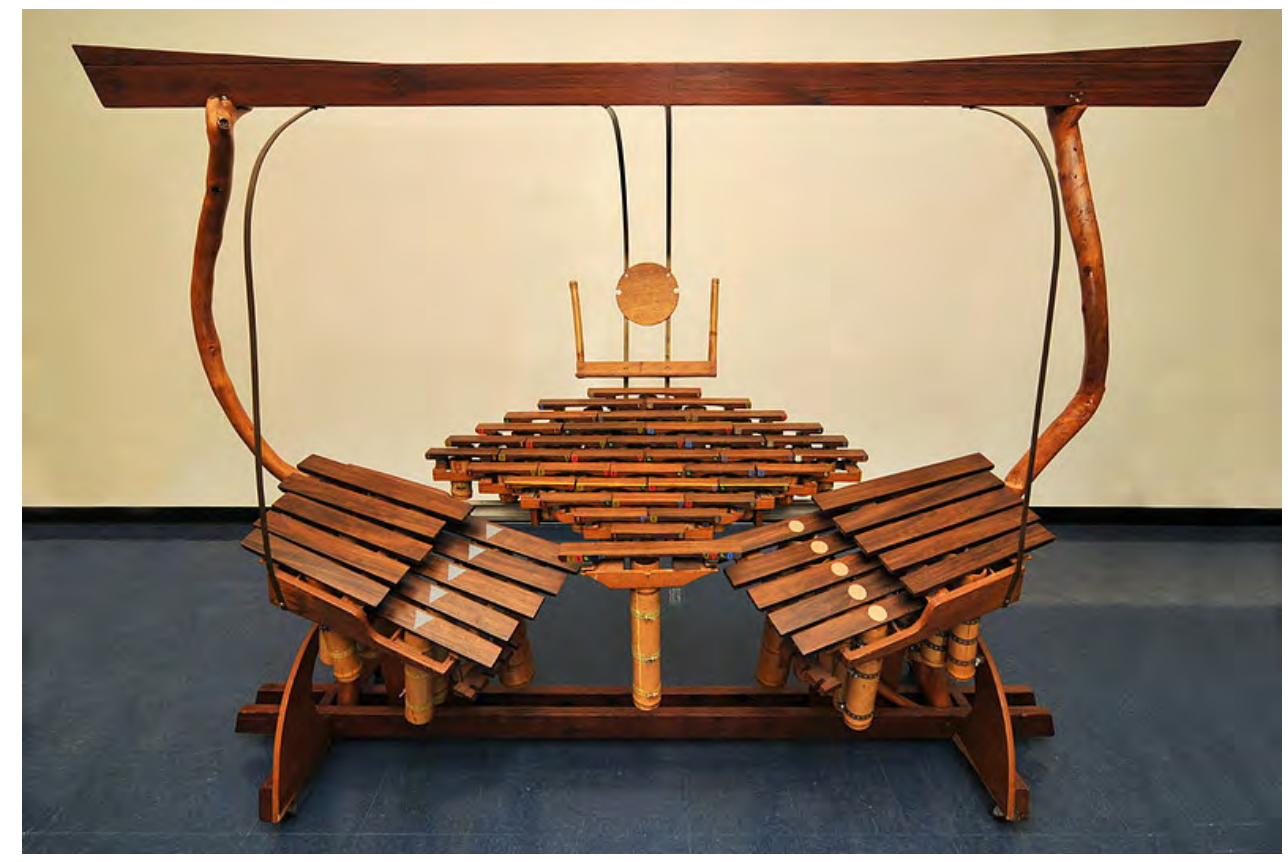

Figura 3 - Quadrangularis Reversum de Harry Partch.

\subsubsection{Walter Smetak}

A produção de Anton Walter Smetak (Zurique, 1913 - Salvador, 1984) é uma referência comum dentro da literatura sobre música brasileira no que diz respeito à construção experimental de instrumentos e a experimentos com música microtonal. Tragtenberg (1991), Scarassatti (2008), Obici (2014) mencionam a obra de Smetak como uma espécie de ponto inicial de uma luteria experimental brasileira, em parte devido às características da obra em si - de fato uma produção que rompe com as limitações da luteria tradicional e aproxima esta produção de outras linguagens - e também devido à influência que Smetak teve na produção de diversos construtores de instrumento / artistas sonoros e criadores no Brasil, como Marco Antônio Guimarães, Fernando Sardo e Wilson Sukorski.

Smetak viveu no Brasil a partir de $1937^{84}$, atendendo a um convite para integrar uma orquestra em Porto Alegre. Em sua formação e atuação na Europa até 1937 passou por centros de atividade musical intensa como Viena e Salzburgo, e seu primeiro contato com a luteria tradicional ocorre neste período, frequentando informalmente os ateliês de 
luthiers diversos nas cidades por onde passou e aprendendo com estes técnicas tradicionais de construção de instrumentos ${ }^{85}$.

No período entre 1937 e 1957 Smetak mora em Porto Alegre, Rio de Janeiro e São Paulo, atuando como violoncelista freelancer em diferentes orquestras e formações de câmara, e também como professor de violoncelo ${ }^{86}$. Neste período também compôs repertório para formações tradicionais e realizou alguns estudos de eletrônica que resultaram na criação de um microfone de contato, projeto que é patenteado no Brasil mas cuja produção não foi levada adiante em maior escala devido à falta de recursos. É também neste período que Smetak entra em contato com a Eubiose, ramo da Teosofia criado no Brasil que terá um grande impacto em sua produção ${ }^{87}$.

Em 1957, após uma breve viagem à Europa por consequência do falecimento de seu pai, Smetak passa a viver e lecionar em Salvador a convite de Hans-Joachim Koellreuter ${ }^{88}$, integrando os Seminários de Música da $\mathrm{UFBA}^{89}$. A partir de 1961 começa a desenvolver um trabalho de pesquisa e construção de novos instrumentos musicais, atividade que vai balizar suas atividades até seu falecimento em 1984. Smetak cita como influência para o início desta atividade o contato com a música concreta através de um concerto organizado por Koellreuter na Bahia em $1961^{90}$.

É atribuída a Smetak a criação de 176 instrumentos musicais ${ }^{91}$, para os quais Scarassatti (2015, p. 157) propõe a seguinte classificação, à qual acrescenta alguns exemplos:

Instrumentos de inspiração no primitivo, no milenar em busca do novo Boréis, Vinas, a Árvore, os Tímpanos, Sinos, Fiddle, Gambus Orientalis e a família dos Choris.

Instrumentos cinéticos Ronda, 3 Sóis, Mulher Faladeira, Mimento e Máquina do Silêncio.

Instrumentos coletivos Pindorama, Grande Virgem, Sextante e Mister Play-Back.

Microtonais Conjunto de violões microtonais, e o conjunto dos monocórdios com afinação microtonal.

85 (SCARASSATI, 2008, p. 39), (SMETAK, 2001, p. 213)

86 (SCARASSATI, 2008, p. 39-44). Ernst Widmer (apud (SMETAK, 2001, p. 17)) sugere que Smetak teria também exercido a profissão de luthier, no sentido tradicional, para complementar sua renda neste período, no Brasil.

87 (SCARASSATI, 2008, p. 41-43)

88 Hans-Joachim Koellreuter (Freiburg, 1915 - São Paulo, 2005) foi um compositor, professor e musicólogo alemão que viveu no Brasil a partir de 1937, tendo sido uma figura muito influente na vida musical brasileira do século XX. Disponível em:<https://pt.wikipedia.org/wiki/Hans-Joachim_Koellreutter $>$. Acesso em 23 de janeiro de 2018.

89 (SCARASSATI, 2008, p. 45)

90 (SMETAK, 2001, p. 41)

91 (SCARASSATI, 2008, p. 24) 
Plásticas sonoras silenciosas Metástase, Imprevisto e Caossonância.

Em 1966 a participação na I Bienal de Artes Plásticas, na Bahia, ocasiona o surgimento da denominação Plásticas Sonoras, utilizada pelo curador Juarez Paraíso em referência aos instrumentos de Smetak. O termo seria adotado pelo próprio Smetak para referir-se à sua produção, e passaria a designar toda sua produção instrumental ${ }^{92}$.

Obici (2014, p. 105-109) enumera alguns pontos de diálogo entre a produção de Smetak nos anos 1960 e a dos demais artistas reunidos na exposição Nova Objetividade Brasileira, realizada em 1967 e da qual Smetak participou com seu instrumental e plásticas sonoras. Os pontos enumerados por Obici se organizam de acordo com a seis tendências à Nova Objetividade, apontadas por Hélio Oiticica ${ }^{93}$. A obra de Smetak, segundo Obici, se relacionaria com alguns destes pontos da seguinte forma:

Vontade construtiva Tendência manifesta na busca de Smetak por superar o colonialismo cultural no meio musical e artístico ao propor uma produção que transcenda essas heranças partindo de uma perspectiva brasileira;

Tendência ao objeto Smetak já é reconhecido por Oiticica como um expoente desta tendência por seus "instrumentos de cor (musicais)" "94. Esta é uma tendência que se manifesta na "noção de luteria como forma de composição musical, que retiraria a composição do lugar exclusivo da partitura", num paralelo com a superação do quadro e do cavalete ${ }^{95}$;

Participação do espectador No sentido de "participação sensorial-corporal", esta se manifesta na renegociação das fronteiras entre público - artista - partitura - instrumento, no uso da improvisação como processo criativo e compositivo, e na criação de instrumentos coletivos como Pindorama. Já no sentido de "participação semântica", Obici aponta para o papel central da simbologia e da estética visual nas criações de Smetak $^{96}$;

Ressurgimento da antiarte O próprio Smetak define por vezes suas obras como antiinstrumentos, e segundo Obici esta tendência se manifesta na busca de "criar novas condições experimentais", em que o artista assuma novos papéis ${ }^{97}$.

92 (SCARASSATI, 2008, p. 50)

93 As tendências apontadas por Oiticica estão listadas em Esquema geral da nova objetividade, texto que integra o catálogo da exposição, de 1967, e são "vontade construtiva; tendência para o objeto, ao ser negado e superado o quadro de cavalete; participação do espectador; tomada de posição em relação a problemas políticos, sociais e éticos; tendência a uma arte coletiva; ressurgimento da antiarte" (OBICI, 2014, p. 106)

94 Oiticica apud (OBICI, 2014, p. 107).

95 (OBICI, 2014, p. 108).

96 (OBICI, 2014, p. 109).

97 (OBICI, 2014, p. 108). 


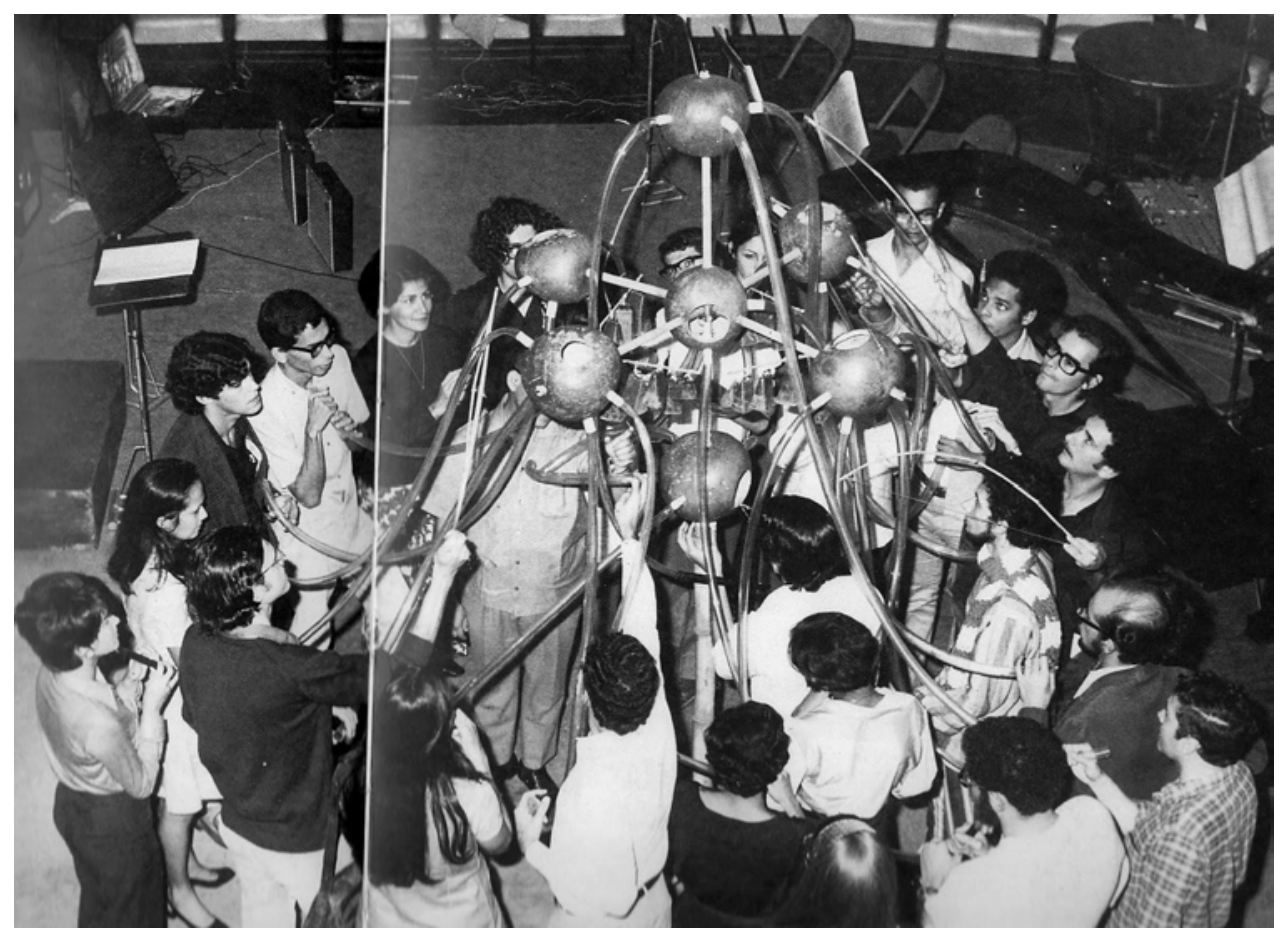

Figura 4 - Pindorama, instrumento coletivo de Walter Smetak em concerto regido por Ernst Widmer em 1969. Foto: Acervo da Associação de Amigos de Walter Smetak.

Na escolha dos materiais utilizados para desenvolver seus instrumentos, Smetak favorece materiais presentes no cotidiano como forma de viabilizar sua produção de modo adequado à condição brasileira ${ }^{98}$, e dentre a vasta gama de materiais possíveis é notável a predileção pela cabaça como matéria-prima, por ter uma relação simbólica com o embasamento filosófico e místico que serve de base para sua produção. Em suas plásticas sonoras, Smetak busca uma unificação simbólica entre forma, cor e sonoridade, sugerindo a possibilidade de ouvir e ver o som como uma unidade ${ }^{99}$.

Com exceção de um contato tardio com a sistematização microtonal de Carrillo 100 em 1980101, não há indícios de que Smetak tenha tido contato com a obra e os instrumentos desenvolvidos por outros compositores e criadores de instrumentos do século XX, como Luigi Russolo, os irmãos Baschet e Harry Partch ${ }^{102}$. Análises de sua produção listadas e ilustradas em Smetak (2001 e 2008), Scarassatti (2008) e Paoli (2011) também não indicam que tenha havido uma influência direta ou mesmo indireta.

\footnotetext{
98 (SMETAK, 2001, p. 62)

99 (SCARASSATI, 2008, p. 46-47)

100 Julián Carrillo (1875-1965) foi um compositor, violinista, regente e teórico mexicano, desenvolveu um sistema microtonal denominado "Sonido 13". Disponível em: < https://en.wikipedia.org/wiki/Julián_ Carrillo $>$. Acesso em 3 de fevereiro de 2017

101 (SCARASSATI, 2008, p. 112)

102 Dourado apud (SMETAK, 2001, p. 22) sugere que Smetak soubesse da produção de alguns destes criadores, mas não há nenhuma menção feita pelo próprio Smetak ou por outros autores na bibliografia utilizada.
} 
No entanto, Smetak compartilha com Russolo (1986) um interesse pela teosofia e a influência desta sobre seu pensamento criativo. No tocante ao microtonalismo, a abordagem microtonal de Smetak parece ser muito mais a consequência de uma pesquisa que parte da escuta e da investigação sonora do que uma sistematização técnica como acontece com Carrillo e Partch, entre outros. Este aspecto investigativo se estende para o processo composicional de Smetak, muito baseado na improvisação e na investigação das possibilidades sonoras e expressivas de seus instrumentos. Para Smetak a improvisação é uma ação transformadora de caráter ritualístico, e está relacionada com a possibilidade de desenvolver coletivamente uma consciência musical ativa ${ }^{103}$.

\subsubsection{Marco Antônio Guimarães}

O trabalho de Artur Andrés Ribeiro (2004) apresenta um panorama da literatura e estudos a respeito de luteria experimental, com ênfase no trabalho do grupo Uakti, formado em Belo Horizonte-MG na segunda metade dos anos 1970, do qual o próprio Ribeiro fez parte.

O grupo Uakti é formado a partir das pesquisas de Marco Antônio Guimarães, músico, compositor e construtor nascido em 1948 em Belo Horizonte. Guimarães estudou música nos Seminários Livres de Música da UFBA entre 1966 e $1971^{104}$, e reconhece ter sido bastante influenciado pelos estudos com Ernst Widmer - no tocante ao processo composicional - e pela experiência junto a Walter Smetak no que diz respeito a desenvolver um trabalho de luteria experimental, a partir de uma vivência prévia de carpintaria e construção de objetos no ambiente familiar. Participou do grupo Uakti desde a sua formação até a dissolução do mesmo em 2015, na qualidade de compositor e construtor de instrumentos, mas deixou de atuar como intérprete nos concertos e turnês do grupo a partir de $1992^{105}$.

Ribeiro (2004, p. 172-227) cataloga e descreve textualmente os 57 instrumentos criados por Guimarães para o grupo Uakti no período entre os anos 1970 e 2004, utilizando o sistema Hornbostel-Sachs para classificar os instrumentos, sendo:

- 9 aerofones de sopro;

- 4 aerofones de percussão;

- 14 idiofones de percussão;

- 1 idiofone à base de água;

- 4 membranofones de percussão;

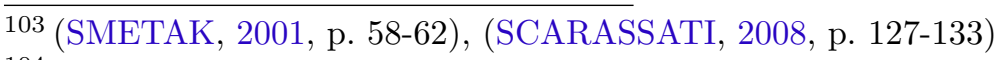

104 (RIBEIRO, 2004, p. 32-44)

105 (RIBEIRO, 2004, p. 62) 
- 1 membranofone de sopro;

- 9 cordofones de fricção;

- 2 cordofones de percussão;

- 13 eletrofones com modos diversos de ativação.

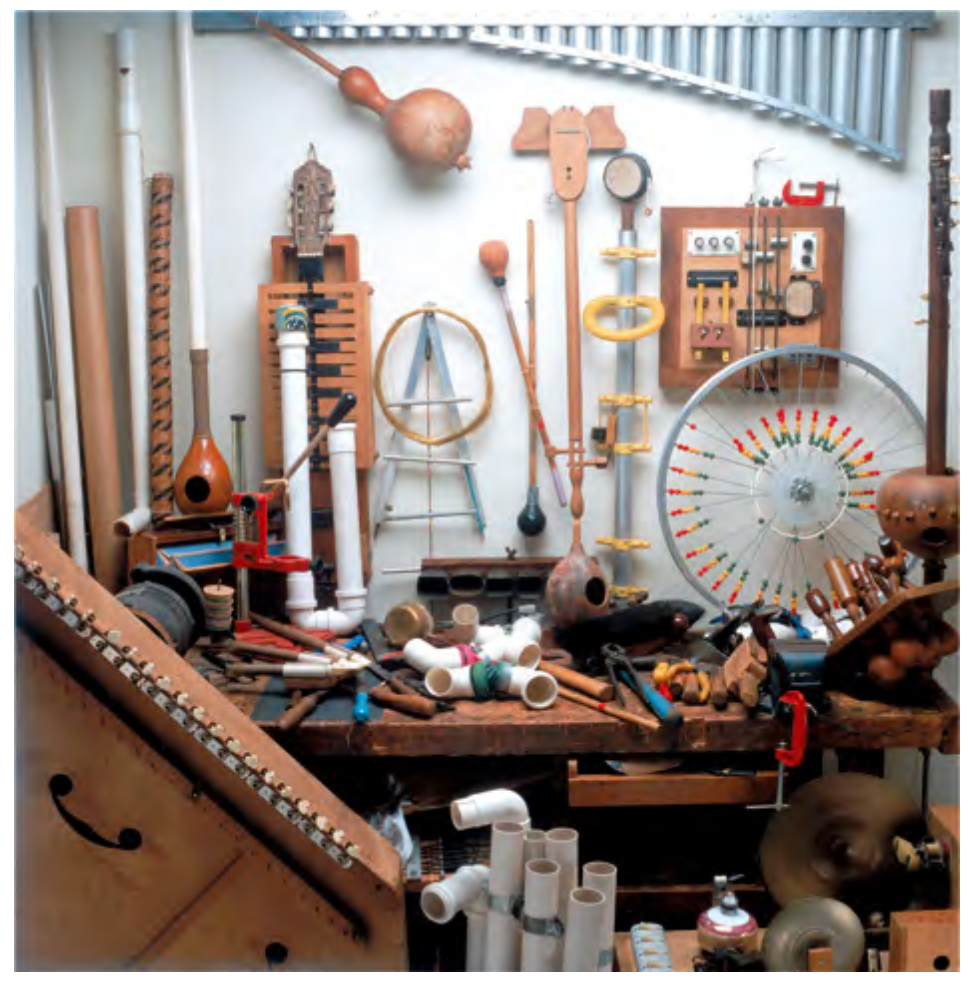

Figura 5 - Oficina de Guimarães, com alguns instrumentos utilizados pelo grupo Uakti. Foto: Acervo Uakti.

A produção de Guimarães utiliza extensamente materiais de origem industrial, devido à necessidade de afinar os instrumentos de forma temperada, no que o PVC se mostrou um elemento resistente e versátil no sentido de permitir essa precisão na afinação ${ }^{106}$. Além do PVC, utilizado em 18 instrumentos, muitas das peças utilizam chapas de compensado de madeira, peças de metal de fabricação industrial - como tampas e panelas de alumínio -, vidro e também cabaças. Ribeiro (2004, p. 111) propõe uma organização das estratégias de criação de instrumentos de Guimarães em 7 pontos:

1. A pesquisa e descoberta sonora exploratória de novos materiais;

2. A pesquisa dirigida, feita a partir de uma necessidade musical do compositor ou do grupo;

3. A elaboração de um resultado sonoro pré-selecionado, por meio da observação de fenômenos físicos naturais; 
4. A pesquisa exploratória, feita a partir de um mecanismo básico de emissão sonora;

5. A projeção de um instrumento a partir de seu desenho ou planta;

6. A modificação ou releitura (utilização não convencional) dos instrumentos tradicionais e de suas técnicas de performance;

7. A pesquisa exploratória feita a partir da reciclagem de materiais sonoros do cotidiano.

Reconhecida a influência do trabalho de Smetak no desenvolvimento de instrumentos realizado por Guimarães, Ribeiro (2004, p. 96-107) enumera pontos comuns entre os dois criadores, assim como algumas divergências. São descritas como diferenças principais:

- Ao contrário da motivação de Smetak em criar novos instrumentos buscando novos sons e, consequentemente, o desenvolvimento de uma nova consciência humana, o trabalho de Guimarães é motivado por uma exploração das possibilidades oferecidas pelos materiais utilizados e pelas técnicas de construção empregadas ${ }^{107}$.

- Smetak tem uma preocupação com a escuta dos elementos constituintes do som e com nuances microtonais. Já o trabalho de Guimarães e do Uakti é notadamente modal e baseado na escala temperada de 12 notas, e mesmo em experimentos microtonais seu trabalho parte de uma sistematização já existente, como no caso da construção de um Pan - nome comum utilizado para os aerofones percussivos criados por Guimarães a partir de tubos de PVC - afinado em quartos de tom ${ }^{108}$.

- Uma preocupação pela coerência entre forma e sonoridade, instigada pela busca de uma dimensão mística do fazer musical, permeia a produção de Smetak $^{109}$. Já no trabalho de Guimarães, ainda que exista uma preocupação com o acabamento dos instrumentos, sua forma e aspecto visual estão condicionados à sua função sonora, e menos relacionados com elementos extramusicais ${ }^{110}$.

Já os traços em comum enumerados por Ribeiro são:

- Uso de materiais cotidianos e de fácil acesso, seja pelo reuso, reciclagem ou pela aquisição $^{111}$.

- Busca de um diálogo entre o repertório musical ocidental e oriental, notadamente a música clássica indiana ${ }^{112}$.

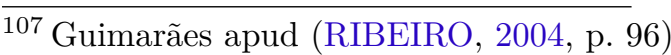

108 Guimarães apud (RIBEIRO, 2004, p. 97)

${ }^{109}$ Guimarães apud (RIBEIRO, 2004, p. 99)

110 Guimarães apud (RIBEIRO, 2004, p. 102)

111 (RIBEIRO, 2004, p. 103)

112 (RIBEIRO, 2004, p. 97)
} 
- Improvisação e experimentação como base do processo composicional ${ }^{113}$.

- Todos os instrumentos construídos tanto por Smetak quanto por Guimarães são únicos, não tendo sido pensados para uma produção em série ${ }^{114}$.

Se Smetak pode ser considerado como um ponto inaugural em termos de luteria experimental no Brasil, o grupo Uakti pode ser considerado como o principal difusor deste tipo de prática entre os anos 1980 e 2000, pelo menos no tocante à construção de instrumentos experimentais acústicos. Por ter tido uma relação com grandes veículos midiáticos, ter lançado discos por gravadoras e trabalhado repetidamente com artistas fonográficos e também trilhas para cinema, o grupo passou a ser associado com a prática de construção de instrumentos.

\subsubsection{Patrick Ozzard-Low}

O trabalho de Patrick Ozzard-Low (1998) é citado por Ribeiro (2004) como uma referência importante em termos de sistematização das possíveis abordagens na construção de instrumentos musicais experimentais. Na descrição do projeto 21st Century Orchestral Instruments: Acoustic instruments for alternative tuning systems, Ozzard-Low (1998, p. 1) define algumas linhas principais para o design, desenvolvimento e performance de instrumentos musicais na contemporaneidade:

1. refinamentos em instrumentos acústicos convencionais e suas técnicas de performance;

2. técnicas de execução avançadas e não convencionais para instrumentos convencionais;

3. projeto e construção de instrumentos originais ou não ortodoxos (acústicos e semiacústicos);

4. desenvolvimento de instrumentos e aparatos eletrônicos e eletroacústicos;

5. desenvolvimento de adaptações acústicoeletrônicas para instrumentos convencionais;

6. o desenvolvimento radical de instrumentos orquestrais puramente acústicos.

O projeto de Ozzard-Low se desenvolve em parceria com a London Guildhall University entre 1998 e $2004^{115}$. No texto de fundação do projeto, Ozzard-Low descreve de modo criterioso e detalhado as perspectivas e os problemas envolvidos no processo de criação de novos instrumentos musicais acústicos, voltados para o repertório contemporâneo de câmara e concerto.

\footnotetext{
113 (RIBEIRO, 2004, p. 97)

114 (RIBEIRO, 2004, p. 104)

${ }^{115}$ Center for New Music Instruments 1998-2004 London Guildhall University <https://youtu.be/ Bp8PTZ8ySLo > Para o ano de encerramento do projeto: $<$ https://youtu.be/Bp8PTZ8ySLo $>$. Acesso em 02 de setembro de 2016.
} 


\subsubsection{Bart Hopkin - Experimental Music Instruments}

Bart Hopkin é músico, etnomusicólogo e construtor de instrumentos estadunidense. Como construtor possui uma vasta produção documentada em sua página da internet ${ }^{116}$, e entre os anos de 1985 e 1999 foi editor do periódico Experimental music instruments, com um total de 70 edições. Ao longo de sua história de publicação, o periódico cobria diferentes aspectos do processo de criação e construção de instrumentos experimentais acústicos, com projetos para construção de instrumentos, recursos técnicos, entrevistas com compositores e construtores, funcionando também como um ponto de encontro e divulgação de criadores e criadoras diversos ${ }^{117}$, tendo contado com colaborações de nomes de referência para a comunidade, como os irmãos Baschet.

O periódico não se propunha, a priori, em cobrir a construção de instrumentos eletrônicos ou digitais, limitando-se à amplificação de instrumentos acústicos ${ }^{118}$. Ao longo dos anos, contudo, alguns artigos sobre circuit bending foram escritos por Qubais Reed Ghazala.

Após o término do periódico Experimental music instruments, Hopkin seguiu produzindo material bibliográfico relacionado com construção de instrumentos musicais, como o livro Musical Instrument Design (1996) e Nice Noise: Modifications and preparations for guitar (2012), este último sobre preparações e modificações para violão e guitarra elétrica, escrito em parceria com o luthier holandês Yuri Landman ${ }^{119}$. Parte dessa produção também é focada a práticas de construção de instrumentos experimentais para uso na educação musical infantil.

\subsection{Readymade}

O termo readymade é usado por Marcel Duchamp a partir de $1915^{120}$ para fazer referência a um novo tipo de obra que vinha realizando desde 1913, baseado em objetos "selecionados, assinados e ocasionalmente alterados por Duchamp, guiados por seu princípio de completa indiferença" ${ }^{121}$. Dentro da obra de Duchamp, os readymades talvez simbolizem de forma mais contundente a atitude do artista em prol de uma definição menos limitante de arte, mais conectada com a importância da prática do que com as convenções institucionais e de mercado ${ }^{122}$ : "Transferidos de uma existência desprezada, como objetos comuns e manufaturados, para a esfera estética, agiam como uma pressão muda e irritante contra os

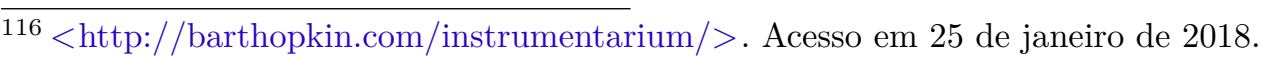

${ }^{117}$ Disponível em: < http://barthopkin.com/about/>. Acesso em 25 de janeiro de 2018.

118 (HOPKIN, 1985)

${ }^{119}$ Landman é um luthier especializado na construção de instrumentos experimentais baseados na guitarra elétrica convencional.

120 (DUCHAMP, 1973, p. 141)

121 (D'HARNONCOURT, 1973, p. 36)

122 (D'HARNONCOURT, 1973, p. 38).
} 
limites convencionais desta esfera"123.

No processo de seleção, Duchamp defendia uma abordagem baseada na "indiferença visual simultaneamente à ausência total de bom ou mau gosto... Na verdade uma anestesia"124, uma estratégia em busca de uma "anestética", uma ausência de estética ${ }^{125}$. Neste sentido, os readymades funcionam como uma espécie de método particular de Duchamp visando uma destruição da arte para si mesmo ${ }^{126}$.

Ainda que não caiba no âmbito deste trabalho aprofundar aspectos da relação de Duchamp com John Cage, acredito ser importante destacar que muito do pensamento de Duchamp teve uma influência na produção musical do século XX por meio da relação entre estes dois artistas. Tancock (1973, p. 165) analisa esta relação e menciona o reconhecimento, entre ambos, sobre a semelhança de suas ideias ainda que tenham chegado a estas por vias diametralmente opostas:

- A rejeição da noção do artista como um criador que dita a forma correta do público acessar a obra;

- A adoção do acaso como método de eliminar traços da personalidade do artista;

- A desconfiança em julgamentos de valor estético.

Para Tancock, Cage adquire estas posturas a partir da sua experiência com o Zen, mas reconhecia em Duchamp um artista que chegara a estas conclusões intuitivamente ${ }^{127}$. Por sua vez, Cage reconhece em si a influência de Duchamp no sentido em que este "chamou atenção para o valor de coisas para as quais normalmente não se agrega valor"128, e em pelo menos duas de suas 26 afirmações sobre Marcel Duchamp sinaliza uma possível influência do método de Duchamp sobre sua abordagem criativa ${ }^{129}$ :

Uma forma de se escrever música: estudar Duchamp.

Duchamp demonstrou a utilidade da soma (bigode). Rauschenberg demonstrou a função da subtração (De Kooning) ${ }^{130}$.

123 (D'HARNONCOURT, 1973, p. 36).

124 (DUCHAMP, 1973, p. 141)

125 (D'HARNONCOURT, 1973, p. 38).

126 (D'HARNONCOURT, 1973, p. 40).

127 (TANCOCK, 1973, p. 165).

128 (CAGE, 1967, p. 36)

129 (CAGE, 1967, p. 71-72)

${ }^{130}$ Nesta afirmação Cage faz referência ao readymade $\boldsymbol{L} . \boldsymbol{H}$.O.O.Q., criado a partir de uma reprodução da Mona Lisa sobre a qual Duchamp pinta um bigode, em 1919 ((D'HARNONCOURT, 1973, p. 17)), e a Desenho apagado de de Kooning, criado por Robert Rauschenberg ao apagar um desenho de Willem de Kooning. Disponível em: < https://en.wikipedia.org/wiki/Erased_de_Kooning_Drawing > Acesso em 22 de Novembro de 2017. 
Neste aspecto que aqui chamo de readymade, observo que existe, se não uma influência direta, uma afinidade do método de Duchamp com algumas práticas de luteria experimental. Alguns autores, como veremos nesta seção, usam o termo readymade para fazer menção ao uso de objetos, gravações sonoras e mesmo instrumentos musicais sendo recontextualizados sonora e musicalmente.

Parte deste modo de uso possui uma relação com o desenvolvimento tecnológico aplicado à música, no que faço aqui um pequeno aparte para comentar estas influências usando como referência a classificação proposta por Michel Chion (1994, p.13-23). Chion propõe um agrupamento das tecnologias do som surgidas entre o final do século XIX e o final do século XX no que chama de seis efeitos técnicos de base. Para o que estamos chamando aqui de aspecto readymade, três destes efeitos possuem uma importância fundamental: a captação e a fonofixação, ambas comumente encadeadas com o efeito técnico da amplificação ${ }^{131}$.

O advento de tecnologias de captação ou transdução sonora permite que novas fontes sonoras em potencial sejam reveladas para intérpretes e compositores. O microfone em sua forma tradicional - que transforma o movimento mecânico do ar em um sinal elétrico - permite ouvir detalhes que a audição normal por vezes não percebe, ou focar em aspectos específicos de uma fonte sonora. O conjunto microfone - amplificador - alto-falante torna-se um instrumento de uma escuta alternativa, permitindo que qualquer tipo de fonte sonora seja explorada em seus potenciais. Transdutores baseados em cristais piezoelétricos - cujo princípio é uma variação de corrente elétrica gerada pela deformação de pequenos cristais - são comumente conhecidos como microfones ou captadores de contato, e amplamente utilizados tanto na amplificação de instrumentos tradicionais, como instrumentos de corda, e também como ferramenta para transformar outros objetos em instrumentos, permanentes ou temporários. A este respeito, Collins comenta:

Fazemos microfones de contato em uma oficina, usando componentes que valem alguns poucos dólares, você gasta 15 minutos pra fazer e pode ser um instrumento fantástico, pode mudar a sua vida. Eu conheço pessoas que estão fazendo música com microfones de contato desde 1978, enfim, foi uma mudança tão grande pra estas pessoas que se tornou seu instrumento ${ }^{132}$.

Outros tipos de transdução podem ser obtidos utilizando-se captadores eletromagnéticos e também indutores eletrônicos que captam vibrações eletromagnéticas. Estes captam interferências e oscilações no campo eletromagnético que em sua maioria são inaudíveis, mas que se tornam passíveis de amplificação e reprodução por meio de alto-falantes.

\footnotetext{
${ }^{131}$ Em Lima (2013, p. 20-28), o autor discute estes efeitos e propõe uma relação entre estes e os deslocamentos acusmáticos como definidos por Emmerson (1994), a saber o deslocamento temporal, o deslocamento espacial e o deslocamento causal.

132 Collins apud (FERNANDEZ; LIMA, 2016, p. 12)
} 
A fonofixação permite a manipulação de sons a partir de sua fixação em um suporte, e sua existência em si é uma condição transformadora que permite que procedimentos como montagem, colagem e citação, extensamente explorados nas artes visuais desde princípios do século XX, sejam aplicados a materiais sonoros. Cutler (2005, p. 144) entende esta apropriação como análoga ao readymade, e chama a atenção para o hiato temporal de 25 anos entre Porte-bouteilles de Duchamp ${ }^{133}$ e Imaginary Landscapes de John Cage, que faz uso de discos pré-gravados como instrumentos de performance ${ }^{134}$, no sentido em que, apesar da ideia de reutilização de objetos já estar presente na produção artística pelo menos desde os anos 1910, há uma certa demora até este tipo de procedimento se manifestar na criação musical e na arte sonora.

Retomo a discussão sobre readymades citando Bourriaud, que destaca a relação do readymade com a lógica dos mercados de consumo e a vida sob a influência da industrialização:

Quando Marcel Duchamp, em 1914, expõe um porta-garrafas e o utiliza como 'instrumento de produção' um objeto fabricado em série, ele transporta o processo capitalista de produção (trabalhar a partir do trabalho acumulado) para a esfera da arte, ao mesmo tempo inscrevendo o papel do artista no mundo das trocas: de repente ele parece um comerciante, cujo trabalho consiste em transferir um produto de um local para o outro ${ }^{135}$.

Não só a presença do readymade no contexto da exposição de arte instiga uma discussão sobre o fazer artesanal em uma era industrial, como também traz à tona uma discussão importante sobre o mercado da arte, alvo de questionamentos e críticas de Duchamp ao longo de sua vida e obra ${ }^{136}$. De modo semelhante, questionamentos desta natureza estão presentes em obras como Imaginary Landscapes e na produção de artistas como Christian Marclay, que faz uso do disco fonográfico como readymade tanto como objeto físico quanto como conteúdo sonoro ${ }^{137}$.

Obici (2014, p. 53) também chama a atenção para esta relação entre o conceito de readymade - assim como de outros procedimentos adotados pelas vanguardas artísticas no início do século XX - com práticas musicais contemporâneas, tanto no nível do reaproveitamento de conteúdos sonoros quanto no reaproveitamento de materiais e equipamentos já

\footnotetext{
133 Tido como o primeiro readymade intencional, trata-se de um secador de garrafas industrializado, comprado por Duchamp numa loja de departamentos (D'HARNONCOURT, 1973, p. 14).

${ }^{134}$ Cutler (2005, p. 145) cita exemplos anteriores a 1939 em que discos foram usados em peças musicais ou artísticas, como uma performance de Stefan Wolpe em um evento dadaísta em 1920, a obra Pini di Roma de Respighi, que faz uso de uma gravação de um rouxinol em um trecho específico, e experiências de Milhaud, Moholy-Nagy e Varése com manipulação de discos, mas para o autor estas instâncias não se configuram como uma obra finalizada concebida a partir do disco fonográfico.

135 (BOURRIAUD, 2009, p. 19), itálicos no original

136 (D'HARNONCOURT, 1973, p. 40).

137 (DEMERS, 2010, p. 55)
} 
existentes. Em sua análise, Obici faz uso do termo bricolagem ${ }^{138}$, um termo que também é utilizado por Fernandez (2013, p. 42) para se referir a este tipo de produção baseada no reaproveitamento e na ressignificação de conteúdos sonoros e de objetos industrializados, destacando também a relação com Duchamp. Além de Obici e Fernandez, Scarassatti (2008, p. 81) também faz uso do termo bricolagem e da figura do bricoleur para descrever práticas artísticas semelhantes ${ }^{139}$

Possuindo algumas semelhanças com a figura do bricoleur, a figura do trapeiro é utilizada por Fernandez ${ }^{140}$ para descrever uma prática de criação de instrumentos musicais que não somente se vale de objetos existentes como readymades, mas que também busca recontextualizar objetos e equipamentos sonoros descartados ou tidos como obsoletos. Este é um procedimento muito comum no Circuit Bending, uma das práticas que Fernandez discute sob a denominação de Circuito Alterado e que será mencionada adiante ${ }^{141}$. A figura do trapeiro também parece oportuna para descrever a dimensão de construção de instrumentos observada na produção de música industrial dos anos 1970 e 1980, discutida no item 1.3.1.

Hertz e Parikka (2012, p. 426) também destacam a relação entre readymades e outras práticas artísticas do início do século XX com a reutilização de objetos e equipamentos contemporâneos, chamando atenção para uma mudança de paradigma neste uso à medida que a produção industrial se concentra em equipamentos eletrônicos ${ }^{142}$, como no trabalho de Nam June Paik com televisores já nos anos 1960.

O modelo de obsolescência programada, comum através da indústria, é descrito por Sterne (2007, p. 20-21) a partir do exemplo da montadora estadunidense General Motors que, a partir de 1923, passa a introduzir novos modelos de carro anualmente, com mudanças de estilo anuais e mudanças em sua tecnologia a cada três anos. Sterne chama a atenção para o fato de que o modelo econômico de obsolescência programada tem em suas origens uma preocupação estilística, estética e não só uma preocupação econômica, e que a noção de obsolescência está frequentemente associada à ideia de progresso tecnológico.

$\overline{138}$ O termo bricolagem, no contexto dos autores aqui citados, tem relação com a definição de bricoleur segundo Lévi-Strauss (1962) em O pensamento selvagem:

[O] bricoleur está apto a executar um grande número de tarefas diversificadas porém, ao contrário do engenheiro, não subordina nenhuma delas à obtenção de matérias-primas e de utensílios concebidos e procurados na medida de seu projeto: seu universo instrumental é fechado, e a regra de seu jogo é sempre arranjar-se com os 'meios-limites', isto é, um conjunto sempre finito de utensílios e de materiais bastante heteróclitos, porque a composição do conjunto não está em relação com o projeto do momento nem com nenhum projeto em particular, mas é o resultado, contingente de todas as oportunidades que se apresentam para renovar e enriquecer o estoque ou para mantê-lo com os resíduos de construções e destruições anteriores.

${ }^{139}$ Em 2.1 mais detalhes sobre o trabalho de Obici e Fernandez são discutidos.

140 (FERNANDEZ, 2013, p. 34).

${ }^{141}$ Ver 2.1

142 (HERTZ; PARIKKA, 2012, p. 426) 
A prática de obsolescência programada em nível industrial ganha fôlego durante a Grande Depressão, como uma estratégia para aquecer a economia ${ }^{143}$, e pelo menos desde os anos 1950 se consolida como um padrão de produção industrial ${ }^{144}$.

O outro lado deste processo é a geração de uma quantidade sem precedentes de descarte de bens manufaturados e tecnológicos ${ }^{145}$. Como discuto em 1.3.1, o excesso material na contemporaneidade se relaciona com o uso de objetos descartados como material de produção e criação artística.

\subsubsection{O readymade industrial}

Entre meados dos anos 1970 e meados dos anos 1980 surge, na cena musical alternativa de centros urbanos europeus e estadunidenses, uma geração de artistas que convencionou-se associar ao termo Industrial, ainda que o entendimento e a adoção do termo varie significativamente de artista para artista. O termo é muito associado ao coletivo britânico Throbbing Gristle, à sua gravadora, Industrial Records, e aos artistas lançados por ela. Com o tempo o termo passou a ser associado a outros artistas que não possuíam uma relação direta com este núcleo produtivo ${ }^{146}$.

Esta é uma produção musical que se relaciona com a produção artística em outras linguagens - dedicada a uma "investigação mais profunda sobre o declínio do capitalismo"147 - de artistas como Monte Cazazza, Mark Pauline e o coletivo Survival Research Laboratory, e Johanna Went, entre outros. O termo, como descrição de um gênero musical, no contexto britânico e estadunidense tem a intenção de subverter a noção de uma indústria da música - no caso, a indústria fonográfica ${ }^{148}$ - e também chamar a atenção para aspectos do modo de vida em sociedades hiperindustrializadas.

Existe uma relação direta entre movimentos artísticos como o Dada, a obra de Duchamp, e outras vanguardas artísticas e a produção dos artistas do gênero industrial. Cox e Warner ${ }^{149}$ apontam para a relação entre o pioneirismo de Russolo e sua influência sobre movimentos como a música industrial, conforme a observação de Brown a respeito da influência de Russolo por via do Dadaísmo e de outros movimentos artísticos, uma relação que também é apontada por Reynolds (2005) ${ }^{150}$. Tanto o coletivo Throbbing Gristle como o coletivo COUM transmissions, do qual o primeiro se originou em 1976, foram diretamente influenciados por movimentos artísticos de vanguarda ${ }^{151}$, seja no aspecto da

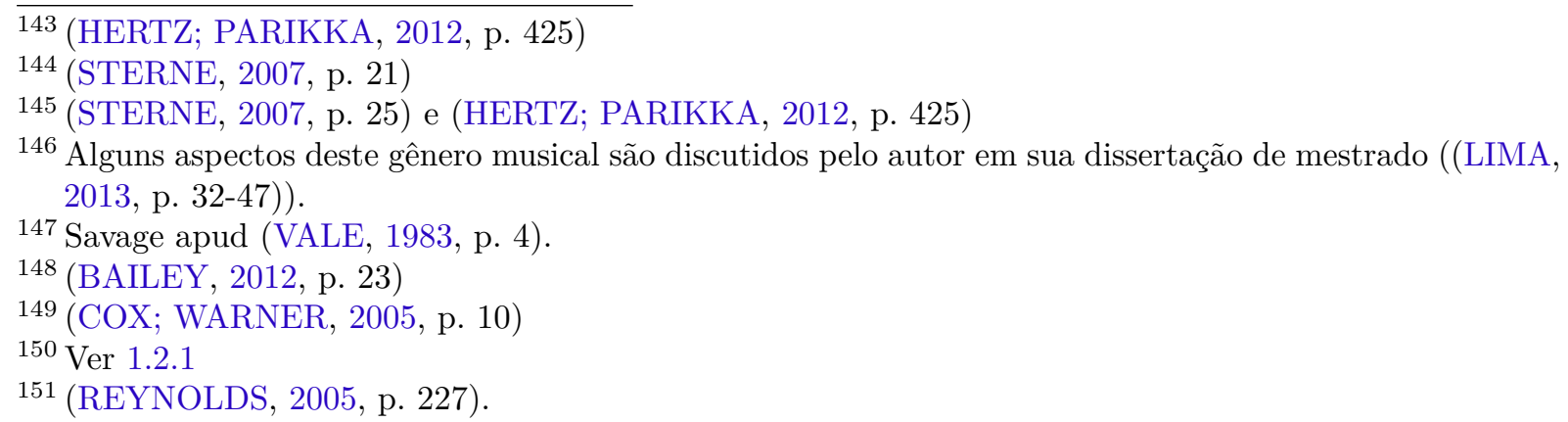


atuação em grupo, seja em sua atitude em relação ao mercado da arte e da música:

A natureza conscientemente antiprofissional, propositalmente naïf da produção do grupo deve muito, estilisticamente, a outras manifestações artísticas do século XX baseadas em uma identidade de grupo - principalmente Dada, o Surrealismo, Fluxus e o Acionismo vienense ${ }^{152}$.

Especificamente no caso do Throbbing Gristle, o aspecto readymade tem a ver com a dimensão do conteúdo sonoro, recontextualizado a partir de um teclado construído por Chris Carter e tocado ao vivo por Peter "Sleazy" Christopherson, que consistia em um reprodutor de fitas cassete com sons pré-gravados diversos ${ }^{153}$, e que em alguns momentos assume o protagonismo vocal das músicas, como no caso da faixa Weapon Training ${ }^{154}$. Também se observa a construção de equipamentos eletrônicos, como o sintetizador e processador de efeitos conhecido como Gristleizer, criado por Carter a partir da adaptação de um circuito para um pedal de guitarra publicado em uma revista de eletrônica para hobbistas. Na época, Carter já desenvolvia instrumentos eletrônicos por conta própria devido a um interesse particular por eletrônica, mas também motivado pela falta de recursos financeiros:

$[\mathrm{O}]$ fator primordial para decidir qual o equipamento para tocar ao vivo era a minha falta de orçamento. Meu setup era estruturado ao redor de um sintetizador modular que eu mesmo construí, vários processadores de efeito também construídos por mim e alguns delays de fita comerciais, mas que eu submeti a algumas modificações ${ }^{155}$.

Outra característica que se observa nos artistas e coletivos desta geração é a recontextualização de materiais descartados ${ }^{156}$, em sua maior parte coletados em ferrosvelhos, terrenos baldios ou também através da relação com catadores e trapeiros, como relata Angus Farquhar, um dos fundadores do coletivo britânico Test Dept:

Naquela época andando umas 10 milhas de Deptford ${ }^{157}$, ao longo do Tâmisa, havia uns ferros-velhos impressionantes, cada qual com sua especialidade. [...] Catávamos coisas em prédios antigos - procurávamos por tubulações antigas que pudéssemos cortar em pedaços menores [...] Quando íamos para os Estados Unidos, claro, não tínhamos como levar nada, então precisávamos gastar dois ou três dias catando

152 (BAILEY, 2012, p. 21)

153 Carter apud (VALE, 1983, p. 17).

154 (BAILEY, 2012, p. 24). A faixa pode ser ouvida em: <https://www.youtube.com/watch?v= Nujy7QJvFVM>. Acesso em 10 de dezembro de 2017.

${ }^{155}$ Chris Carter, informação pessoal em 24 de fevereiro de 2015

156 Russo, Warner apud (COX; WARNER, 2005, p. 52)

${ }^{157}$ N. do autor: Bairro na região sudeste de Londres onde o coletivo tinha seu atelier. 
materiais antes de poder fazer um show. Havia uma certa pressão, pois nunca sabíamos de antemão com o que iríamos lidar sonoramente, mas havia certos objetos genéricos que sempre conseguíamos encontrar, como tanques de água e molas de caminhão ${ }^{158}$.

A mesma abordagem também é observada em outros grupos e artistas da mesma geração como Einstürzende Neubauten e $\boldsymbol{Z}$ 'ev, atuando respectivamente em Berlim Ocidental, na Alemanha, e São Francisco, nos Estados Unidos. Esta abordagem se relaciona com a falta de recursos ${ }^{159}$, no que a coleta e o reaproveitamento de materiais com a finalidade de construir instrumentos musicais surge como uma solução viável. Neste aspecto, a falta de recursos em nível individual - ou do coletivo artístico - encontra uma solução no excesso de materiais, objetos e bens de consumo produzidos e descartados nos grandes centros urbanos: "Z'ev [...] tem a ver com o fato de que você pode sair e construir e criar sua própria música - você não precisa ir em uma loja e comprar as coisas musicais mais novas" ${ }^{160}$. Em alguns casos, estes artistas também recorrem ao furto de materiais para compor seu instrumental ${ }^{161}$.

Assim como no caso do Test Dept, o trabalho do coletivo alemão Einstürzende Neubauten também se relaciona com a ideia de música industrial enquanto música folclórica, autóctone, nativa de uma era industrial, expressa no termo Industrielle Volksmusik ${ }^{162}$. Segundo Blixa Bargeld, fundador do coletivo, esta noção está mais associada a uma produção espontânea de música na era industrial, da mesma forma que outras populações de outras épocas e lugares produziam sua música de acordo com as condições dadas: "Em Berlin Ocidental havia muitos destroços, coisas quebradas e lugares abandonados. Eu pensei: vamos fazer um disco étnico" ${ }^{" 163}$. Baseado na costa oeste dos Estados Unidos, Z'ev também se inspirava em uma variedade de tradições de místicas e espiritualistas e aplica estes procedimentos dentro do contexto do pós-industrialismo dos grandes centros urbanos $^{164}$.

Nos diversos casos citados, a chamada música industrial emula a paisagem sonora hiperindustrial, seja ao transformar seus elementos em instrumentos - percussão de objetos achados, ferramentas elétricas - ou ao recriar as texturas e ritmos da urbe e da indústria, ou reutilizar sua poesia de instruções e palavras de ordem ${ }^{165}$.

\footnotetext{
${ }^{158}$ Disponível em: <http://www.factmag.com/2015/08/17/metal-in-motion-the-story-of-uk-industrial-pioneers-test-dept/ $>$. Acesso em 22 de outubro de 2017.

159 (REYNOLDS, 2005, p. 488)

160 Z'ev apud (VALE, 1983, p. 109).

${ }^{161}$ Z'ev apud (VALE, 1983, p. 109-111)

162 2005, p. 488. O termo pode ser traduzido como "Música folclórica industrial".

163 Bargeld apud Reynolds (2005, p. 485)

164 Z'ev apud (VALE, 1983, p. 113-115)

${ }^{165}$ P-Orridge apud (VALE, 1983, p. 11).
} 


\subsubsection{Qubais Reed Ghazala}

Outro artista que lida com a questão do excesso e do descarte de bens de consumo e da prática industrial da obsolescência programada, mais especificamente de bens de consumo eletroeletrônicos, é Qubais Reed Ghazala. Ghazala é reconhecido como um dos principais pioneiros na prática experimental de criar curto-circuitos em aparelhos eletrônicos buscando gerar novas sonoridades ${ }^{166}$, prática à qual dá o nome de Circuit

\section{Bending.}

No periódico Experimental Music Instruments o nome de Ghazala surge em um texto de Hovancsek (1992a, p. 6-7) ${ }^{167}$, e o próprio Ghazala passa a publicar regularmente artigos sobre seus instrumentos a partir da edição seguinte ${ }^{168}$, quando o termo Circuit Bending é utilizado pela primeira vez ${ }^{169}$. A colaboração de Ghazala com o periódico vai durar até o fim de sua publicação em 1999, na qual publica um apanhado de suas técnicas e ideias a respeito da prática de Circuit Bending ${ }^{170}$.

A prática do Circuit Bending se dá através de um processo exploratório e inquisitivo pelo qual uma pessoa descobre conexões alternativas no circuito de um brinquedo ou equipamento que produza sons eletrônicos, de modo a obter modificações dos sons originais, ou descobrir sons que não foram previstos em seu design. A este processo Ghazala dá o nome de "eletrônica do acaso"171, como uma forma de não aderir "à teoria, ao design do circuito ou à composição" 172 e ressaltando a importância do imediatismo ao lidar com a eletrônica e ao potencial sonoro contidos nestes aparelhos, em oposição ao aprendizado formal ${ }^{173}$. Ghazala relata que descobriu estes procedimentos por acidente, ao gerar um curto circuito em um pequeno amplificador à pilhas, jogado no fundo de uma gaveta: "o fundo do amplificador havia caído, expondo o circuito. Ele estava em contato com algo metálico, que gerou um curto-circuito e transformou o circuito em um oscilador"174

Em seus artigos, Ghazala comumente faz um paralelo entre o uso da matéria prima encontrada na natureza e o uso de equipamentos e objetos já existentes como matéria prima como dois pontos de partida possíveis para experimentos científicos e musicais ${ }^{175}$.

166 (HERTZ; PARIKKA, 2012, p. 426) e (FERNANDEZ, 2013, p. 8-9).

167 Curiosamente, na edição anterior de Experimental Music Instruments à que fala de Ghazala, Hovancsek (1992b) descreve o trabalho de John Hajeski, cuja produção também lida com a alteração de circuitos, no caso de Hajeski especificamente de circuitos de rádios portáteis. Complementando este mesmo artigo há um comentário do editor do periódico sobre as semelhanças no princípio de operação dos instrumentos de Hajeski e o Crackebox de Michel Waisvisz.

168 (GHAZALA, 1992)

169 (GHAZALA, 2004, p. 99).

170 (GHAZALA, 1999).Diversos exemplos de seus projetos podem ser acessados em seu website: <http: //www.anti-theory.com/bio/>. Acesso em 4 de janeiro de 2018.

171 (GHAZALA, 2004, p. 98).

172 (GHAZALA, 2004, p. 99).

173 (GHAZALA, 2004, p. 100).

174 (GHAZALA, 2004, p. 97).

${ }^{175}$ Em Ghazala (1992, p. 24) o paralelo é feito com os experimentos de Tales de Mileto, já em Ghazala (2004, p. 100) a imagem utilizada é a do uso da casca do coco como idiofone, membranofone ou 
Esta nova matéria prima pode ser encontrada em lojas que vendem bens de segunda mão, brechós, e também a partir do descarte feito por fabricantes e vendedores ${ }^{176}$. Este processo de reaproveitamento do descarte eletrônico tem relação com o que Ghazala chama de limiar da invenção, um momento em que uma tendência inevitável do comportamento humano se manifesta: algo como a descoberta das possibilidades do Circuit Bending feita por Ghazala nos anos 1960 inevitavelmente iria se manifestar ${ }^{177}$.

Outro conceito importante dentro do pensamento de Ghazala é o de instrumentos vivos, instrumentos que estão sujeitos à ação do tempo da mesma forma que outros seres vivos, um conceito associado à ideia de interação física entre a eletricidade do corpo do intérprete com a eletricidade que alimenta o circuito alterado ${ }^{178}$. Em paralelo com o que menciono em 1.3.1, Ghalaza (2004, p. 104) também comenta que o Circuit Bending é uma espécie de música autóctone da era industrial.

Segundo Hertz e Parikka (2012), o trabalho de Ghazala serve para trazer atenção a processos como obsolescência programada e blackboxing, dois processos dentro da produção industrial de bens de consumo eletroeletrônicos, fazendo um contraponto ao que chamam ideologia californiana dentro da indústria ${ }^{179}$. Criações como as de Ghazala fazem uso do que Hertz e Parikka chamam de mídia zumbi: os mortos-vivos da história dos meios de comunicação e da cultura do descarte de bens de consumo. A abordagem de Ghazala, segundo estes autores, está relacionada com uma tradição que tem suas origens na cultura da construção de rádios e do radioamadorismo, no começo do século XX, na cultura eletrônica - no sentido de construção de pequenos aparelhos eletrônicos de forma amadora - após a Segunda Guerra Mundial, e em associações de amadores como o Homebrew Computer Club ${ }^{180}$.

\subsection{Modular}

Diversos inventores criaram instrumentos em caráter experimental a partir de possibilidades técnicas surgidas com a progressiva disponibilidade de eletricidade e componentes elétricos e eletrônicos. Complementando o que foi discutido no item anterior em relação aos efeitos técnicos de base enumerados por Chion (1994, p. 13-23), a ênfase do aspecto

cordofone.

176 (GHAZALA, 1992, p. 25)

177 (GHAZALA, 2004, p. 101). Collins (apud (FERNANDEZ; LIMA, 2016, p. 229)) também fala sobre este processo de descoberta relacionado com o tipo de eletrônica disponível para cada geração. Ver 1.4.2.

178 (GHAZALA, 2004, p.101).

179 A "ideologia californiana" é um termo utilizado em um ensaio de Richard Barbrook e Andy Cameron que critica a postura praticada nas empresas do Vale do Silício "que naturaliza e fornece uma prova tecnológica à filosofia política liberal, encerrando desta forma as chances de futuros alternativos". Disponível em: <http://www.metamute.org/editorial/articles/californian-ideolog >. Acesso em 01 de fevereiro de 2018.

180 (HERTZ; PARIKKA, 2012, p. 426) 
que chamo aqui de modular se dá nos efeitos de geração eletroeletrônica de sons e modelagem de sons por meio eletroeletrônicos.

Na bibliografia sobre o desenvolvimento de instrumentos eletroeletrônicos a partir das últimas décadas do século XIX há uma tendência de estabelecer um percurso histórico que normalmente tem como ponto de partida o desenvolvimento do Telégrafo Musical por Elisha Gray em 1874, e que percorre a criação do Telharmonium (1906), do Theremin (1917) e das Ondes Martenot (anos 1920), entre outros menos citados, normalmente conduzindo o leitor pelo surgimento dos estúdios de música eletroacústica entre o final dos anos 1940 e a década seguinte, e finalmente destacando o surgimento de instrumentos como os sintetizadores modulares a partir dos anos 1960 e outros ao longo dos anos 1970 e 1980. Autores como em Chadabe (1997), Holmes (2002) e Brend (2005), entre outros, apresentam este percurso com pequenas variações, de acordo com o objetivo final de suas narrativas.

O panorama traçado por Salter (2010, p. 181-219) ao descrever historicamente a relação entre performance musical e novas tecnologias segue um percurso bastante semelhante. Este panorama, no entanto, se diferencia um pouco da forma tradicional de apresentação ao evadir duas tendências comuns: limitar a história a uma narrativa do desenvolvimento dos dispositivos como entidades ou objetos isolados, e orientar a narrativa pelo ponto de vista do compositor - no sentido do compositor europeu, também isolado - que procura dar conta de uma extensão da tradição musical europeia, a partir de um ponto de tensão e esgotamento das possibilidades do sistema tonal no final do período romântico, buscando novas cores e timbres para sua paleta criativa.

Ao percorrer este caminho já conhecido, Salter enfatiza o aspecto performativo ligado à introdução de novas tecnologias e novos instrumentos derivados destas, e o modo como a performance desempenha uma função de criar sentido e construir saberes que interconectam a complexa rede de recursos técnicos, demandas artísticas e condições socioeconômicas presentes no momento que esta performance ocorre. Neste sentido, o autor destaca a influência de John Cage em uma mudança no paradigma de performance musical e sua associação com novas tecnologias, ao sugerir critérios para a indeterminação desta performance através dos quais as relações entre os elementos envolvidos se estabelecem de outra forma.

Como forma de descrever esta relação Salter propõe o termo emaranhamento, numa apropriação do uso deste termo na antropologia, sugerindo que a porção "humana" e a porção "técnica" estariam tão entrelaçados em "um conglomerado de relações" que separar a essência de cada parte seria impossível ${ }^{181}$. Este emaranhado dos elementos se diferencia significativamente da ideia de performance que se observa, por exemplo, na forma como instrumentos da primeira metade do século XX como o Theremin e as Ondes 
Martenot são inseridos no contexto da performance musical, sujeitos a uma divisão entre instrumento - intérprete - obra, nos moldes da tradição ocidental.

Dick Raaijmakers (2000) descreve estas narrativas históricas sobre novos instrumentos como parte de uma utopia segundo a qual surgirão ferramentas capazes de realizar sonhos de criação sonora e musical, mencionando como exemplo as especulações de Ferruccio Busoni em seu ensaio de 1907, Esboço de uma nova estética da arte sonora, sobre o Telharmonium de Thaddeus Cahill ${ }^{182}$. O texto de Busoni é, inclusive, uma referência histórica muito utilizada por autores que buscam uma narrativa sequencial de desenvolvimento tecnológico. Para Raaijmakers é fundamental levar em consideração que, ainda que exista uma grande preocupação por parte de pesquisadores, artistas e desenvolvedores, o desenvolvimento tecnológico aplicado à música está condicionado a uma etapa prévia, relacionada desenvolvimento tecnológico pautado por outras prerrogativas:

A ideia de que a tecnologia deveria ser o resultado de um anseio musical intenso e bem definido, e portanto estaria a serviço da música, é completamente equivocada. A tecnologia segue seu próprio padrão e não poderia estar menos preocupada com a música, ou mesmo com a arte ${ }^{183}$.

Outro autor que busca analisar a relação entre música e tecnologia ao longo do século XX levando em conta fatores uma gama maior de fatores é Paul Théberge (1997), que observa as transformações nas relações entre música e tecnologia no século XX a partir do estabelecimento de mercados de consumo e de comunidades estruturadas ao redor do uso de novas tecnologias aplicadas à música.

Théberge descreve o surgimento e as transformações de um mercado de consumo de instrumentos musicais tendo como ponto de partida a história social do piano como bem de consumo. A importância do piano neste caso não se dá somente por conta das inovações no nível do produto mas também no nível do processo de feitura, como um ponto de encontro de diversas tecnologias surgidas na esteira da revolução industrial até o início do século XIX ${ }^{184}$.

Mas além das inovações no instrumento em si e das modificações no seu processo de feitura, o piano é o personagem central em um processo de transformação das relações entre o público consumidor de música e seus meios de acesso por diversos processos ${ }^{185}$ :

- O estabelecimento de redes de distribuição e venda de instrumentos;

\footnotetext{
182 (RAAIJMAKERS, 2000, p. 13)

183 (RAAIJMAKERS, 2000, p. 13)

184 (THÉBERGE, 1997, p. 18).

185 (THÉBERGE, 1997, p. 20-29).
} 
- O surgimento de periódicos e catálogos de venda relacionados com este nicho de mercado;

- O estabelecimento dos primeiros consórcios de fabricantes;

- O estabelecimento de padrões técnicos para a fabricação de instrumentos e acessórios; e,

- A automatização na reprodução de conteúdo musical, por meio do piano automatizado.

Este é um modelo que vai ser reproduzido quando do surgimento dos primeiros órgãos eletrônicos, a partir dos anos $1930^{186}$, e posteriormente vai servir de base para o mercado instrumentos eletroeletrônicos em geral, como o mercado de sintetizadores eletrônicos a partir dos anos 1970 e ao longo das décadas seguintes ${ }^{187}$.

Sobre esse desenvolvimento, destaco aqui três pontos discutidos por Théberge que possuem uma conexão com os temas deste trabalho. O primeiro diz respeito ao que Théberge chama de inovações transetoriais ${ }^{188}$, que podem ser definidas como "inovações geradas em um setor industrial específico que encontram aplicações em outros setores não-relacionados" ${ }^{189}$. Este modelo transetorial vai influenciar significativamente o desenvolvimento de tecnologias aplicadas à música ao longo do século XX, não só pela expansão dos mercados de consumo, mas também como consequência do desenvolvimento de tecnologias para fins militares ${ }^{190}$. O que Théberge chama de inovações transetoriais está relacionado com a observação de Raaijmakers acima, sobre tecnologias aplicadas à música serem consequência do desenvolvimento de tecnologias voltadas para outros fins.

O segundo ponto diz respeito a uma mudança significativa na relação entre produção musical e consumo de bens tecnológicos, que ocorre no período compreendido entre os anos 1970 e 1990 ${ }^{191}$, associada ao surgimento e à incorporação do microprocessador em equipamentos musicais, notadamente sintetizadores e workstations fabricados em série. Théberge ${ }^{192}$ ressalta que este processo não se resume à aquisição pura e simples de equipamentos, mas que as práticas musicais neste período "se alinham com um comportamento mais próximo de uma prática de consumo - significativamente diferente de relações anteriores entre músicos e seus instrumentos como meios de produção"193. No trabalho

\footnotetext{
186 (THÉBERGE, 1997, p. 31).

187 (THÉBERGE, 1997, p. 51).

188 Segundo a definição proposta por André Piatier em PIATIER, A. Transectorial Innovations and the Transformation of Firms. The Information Society, v. 5, n. 4, p. 205-231, 1987/88.

189 (THÉBERGE, 1997, p. 27).

190 (THÉBERGE, 1997, p. 34).

191 (THÉBERGE, 1997, p. 5-6)

192 (THÉBERGE, 1997, p. 6)

193 (THÉBERGE, 1997, p. 6)
} 
de Théberge esta transformação do músico em consumidor de tecnologia é observada no contexto da música popular urbana, mas Collins (2008), por exemplo, descreve um processo bastante semelhante em sua história particular como compositor, e menciona que no cenário de música experimental estadunidense e europeia muitos outros criadores desenvolvem trajetos semelhantes ${ }^{194}$.

Levando-se em conta esta mudança de comportamento descrita no parágrafo anterior, o terceiro ponto descreve o surgimento de grupos de usuário e comunidades criadas para o intercâmbio de informações a respeito do uso e manutenção destes equipamentos baseados em eletrônica analógica e digital. Este não é um processo que se observa somente no contexto musical, tendo sido herdado de outras comunidades semelhantes baseadas no uso de tecnologias digitais. Há um paralelo, dentro da história da música europeia, com a formação de associações e guildas como mecanismos de instrução e inserção profissional ${ }^{195}$, mas uma diferença fundamental neste aspecto é a associação destes grupos de usuários a marcas e modelos específicos ${ }^{196}$. Este é um fenômeno que em parte está associado a um "entusiasmo pela tecnologia" compartilhado por um público de usuários definido por um perfil específico: "homens, em sua maioria jovens, brancos e de classe média"197. Este entusiasmo pela tecnologia também se baseia na crença em um espaço livre, democrático e de amplo acesso no qual, em alguma medida, usuários colaboram para o desenvolvimento dos equipamentos que estas comunidades utilizam ${ }^{198}$. Ao longo desta discussão sobre grupos de usuários, Théberge faz vários paralelos entre as comunidades de radioamadorismo, comunidades de hackers e os grupos estudados ${ }^{199}$.

É justamente a fusão destes argumentos - uma pesquisa técnica e quase científica, de um lado, e um apelo a um projeto social idealista, de outro - que aparentemente se tornou típica de subculturas técnicas e masculinas ao longo do século $\mathrm{XX}^{200}$.

Para Théberge, grupos de usuário não são somente um recurso para o compartilhamento de informações técnicas, mas espaços onde estes consumidores "desenvolvem definições alternativas de suas necessidades e novas formas de satisfação em sua relação com mercadorias e outros consumidores" ${ }^{201}$. Sobre as práticas de alteração de circuitos e construção de projetos eletrônicos Collins também menciona este entusiasmo pela técnica, pela possibilidade de fazer algo, associando em parte o seu interesse nestas práticas à cultura do hobby ${ }^{202}$. A diferença fundamental entre comunidades ou grupos de usuários e

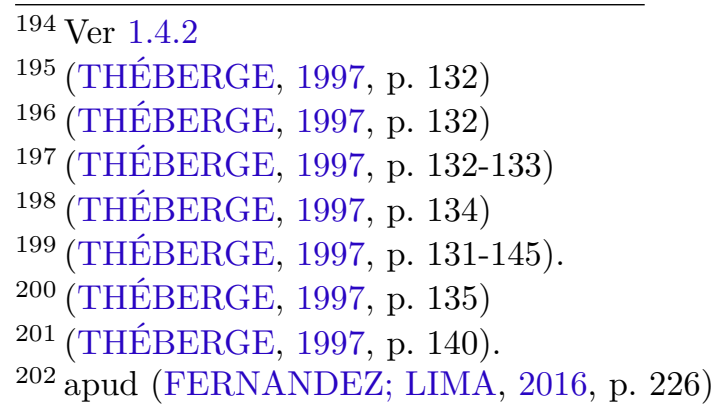


praticantes envolvidos com Circuit Bending ou Hardware Hacking seria a necessidade de possuir determinados equipamentos e utilizá-los de forma correta, no primeiro caso ${ }^{203}$, e uma abordagem que envolve o reaproveitamento e a ressignificação de equipamentos, além de um uso menos ortodoxo, expresso em uma das máximas de Collins (2008, p. 33): "tudo o que a pena ser feito, vale a pena ser malfeito".

Atualizando estas constatações de Théberge, vemos que este continua sendo um meio de intercâmbio de informações. Atualmente diversos fóruns se encontram ativos na internet sobre assuntos os mais diversos, desde práticas de circuito alterado, ou construção e montagem de sintetizadores modulares.

\subsubsection{Sintetizadores}

O advento dos sintetizadores comerciais nos anos 1960 representa uma nova etapa na materialização de um desejo que se manifesta em projetos desde pelo menos o final do século XIX, e é um marco na história da eletrônica analógica aplicada à produção sonora. Isso se deve a fatores tais como a diminuição no tamanho dos circuitos eletrônicos, devido à disponibilidade de transistores e circuitos integrados mais acessíveis ${ }^{204}$, e à possibilidade do controle de parâmetros musicais por meio de voltagens de controle, recurso que se torna uma possibilidade prática por volta de $1964^{205}$, como descrito por Robert Moog (Nova Iorque, 1934 - Asheville, 2005) em um artigo de 1965 ${ }^{206}$.

Outro aspecto importante em relação ao trabalho de Moog é a sua formação técnica a partir do compartilhamento de informações entre amadores - um interesse comum compartilhado com seu pai, engenheiro elétrico - que, aliada ao seu interesse por música, fez com que desenvolvesse vários projetos de instrumentos musicais eletroeletrônicos a partir de revistas direcionadas ao público hobbista ${ }^{207}$. Este interesse eventualmente colaborou para que Moog e seu pai iniciassem um pequeno negócio de construção e venda de kits para montagem de Theremins por correspondência ${ }^{208}$.

A partir da associação com o compositor Herb Deutsch, Moog começa a demonstrar seu protótipo para a comunidade musical acadêmica nos Estados Unidos e Canadá, o que gerou interesse e demanda suficientes para viabilizar a produção de módulos e sintetizadores em série se tornasse viável ${ }^{209}$.

203 (THÉBERGE, 1997, p. 136).

204 (PINCH; TROCCO, 2000, p. 69)

${ }^{205}$ Moog apud (PINCH; TROCCO, 2000, p. 71).

206 (MOOG, 1965)

${ }^{207}$ Moog estudou engenharia e física na Cornell University, mas seu trabalho de pesquisa possuía pouca relação direta com o desenvolvimento de seus sintetizadores (PINCH; TROCCO, 2000, p. 81)

208 (PINCH; TROCCO, 2000, p. 70). O Theremin, por ser um projeto eletrônico relativamente simples de ser construído, é muito encontrado nas biografias de criadores e construtores de instrumentos eletrônicos no séc. XX, como é o caso de Jorge Antunes e Cláudio César Dias Baptista, vide seção 2.1.

${ }^{209}$ Entre os centros que geraram encomendas para Moog neste primeiro momento estão o Toronto Electronic Music Studio e o Columbia-Princeton Studio for Electronic Music(PINCH; TROCCO, 2000, 
Na mesma época e também nos Estados Unidos, mas sem tomar conhecimento da produção de Moog, Don Buchla (South Gate, 1937 - Berkeley, 2016) desenvolveu um sintetizador eletrônico utilizando controle de voltagem para atender às demandas dos compositores Ramon Sender e Morton Subotnick, ligados ao San Francisco Tape Music Center $^{210}$.

Os instrumentos criados por Moog e Buchla, apesar de compartilharem o mesmo princípio de produção sonora, eram completamente diferentes, a começar pela opção de Moog em produzir uma interface de controle na forma de um teclado musical tradicional, mais de acordo com as demandas de um mercado de instrumentos musicais em que o órgão eletrônico era um produto bastante requisitado ${ }^{211}$. Buchla buscava construir um instrumento intencionalmente eletrônico:

Certa vez eu tentei colocar um teclado no meu sistema [...] e me vi dominado pelo aspecto psicológico de olhar para essa estrutura muito familiar de doze notas, e compelido a fazer uma música que ia contra o que eu me condicionava a fazer ${ }^{212}$.

O sucesso comercial dos módulos criados por Moog na segunda metade dos anos 1960, associado a outros fatores como o impacto que o uso dos instrumentos de Moog e Buchla teve na produção musical em diferentes nichos, inspirou uma geração de produtores a desenvolver e comercializar suas criações a partir deste período até o final da década seguinte. Dentre as diversas marcas envolvidas neste processo, destaco aqui a importância da $\boldsymbol{P A \boldsymbol { A } \boldsymbol { A }}$ Electronics, fundada pelo estadunidense John Simonton Jr. (Honolulu, 1943 - Arcadia, 2005) em 1967 para vender kits de projetos eletrônicos pelo correio. Simonton foi um colaborador ativo da revista Popular Electronics, onde diversos projetos comercializados pela PAiA foram disponibilizados livremente ${ }^{213}$.

Importante no processo de criação do sintetizador a partir dos anos 1960 é a ideia de modularidade de seus componentes, partes separadas que podem ser ligadas de diversas maneiras $^{214}$. Esse trabalho a partir de módulos está presente na produção de Collins, Ghazala e outros, e também vai influenciar a separação das etapas no tocante à criação de instrumentos em ambiente digital. O impacto desta ideia também se observa no sentido de tornar mais acessível a construção de instrumentos musicais e aparatos sonoros a partir de componentes menores acessíveis.

\footnotetext{
p. 71)

210 (PINCH; TROCCO, 2002, p. 39).

211 (PINCH; TROCCO, 2000, p. 74)

212 Buchla apud (PINCH; TROCCO, 2000, p. 73)

${ }^{213}$ Disponível em:<https://en.wikipedia.org/wiki/PAiA_Electronics $>$

${ }^{214}$ Moog apud (PINCH; TROCCO, 2000, p. 74).
} 


\subsubsection{Música experimental}

Paralelamente ao processo descrito em 1.4.1, alguns compositores de música experimental desenvolveram um trabalho de composição baseados na construção de circuitos eletrônicos e no uso de equipamentos eletrônicos do dia-a-dia, sob influência do trabalho de John Cage, e muitas vezes trabalhando em conjunto com Cage e com a companhia de dança de Merce Cunningham.

Como pianista, David Tudor (Philadelphia, 1926 - Tomkins Cove, 1996) foi um intérprete importante de compositores contemporâneos entre meados dos anos 1940 e meados dos anos 1960. Ao longo dos anos 1960 Tudor gradualmente deixa de atuar como pianista e desenvolve um interesse pela performance e composição envolvendo equipamentos eletrônicos ao vivo, a partir das experiências em conjunto com John Cage em peças como Cartridge Music de 1960 e Variations II de 1961, e partir deste processo exploratório busca adquirir o conhecimento técnico suficiente para construir seus próprios circuitos ${ }^{215}$. Esta transição para a performance com eletrônica é marcada pela estréia de Rainforest em 1968, obra que seria revisitada e expandida em sucessivas versões até 1973.

Rainforest é uma peça inicialmente feita sob encomenda para a companhia de Merce Cunningham, baseada no uso de captadores de contato - recurso também utilizado em Cartridge Music - cujo sinal é amplificado e reproduzido por transdutores acoplados a diferentes objetos, criando um ciclo de realimentação acústica que pode ser controlado pelos intérpretes da peça. As características ressonantes de cada objeto escolhido vão determinar a sonoridade resultante a partir da realimentação do sinal ${ }^{216}$. Nesta obra, Tudor desenvolve experimentos anteriores realizados nas obras de Cage e também em duas de suas obras, Fluorescent Sound (1964) - criada para uma exposição de Robert Rauschenberg em Estocolmo 217 - e Bandoneon! (1966) - criada para o evento 9 Evenings of Theatre and Engineering -, ambas baseadas também no uso de captadores de contato acoplados a fontes sonoras distintas, amplificando sons de pouca intensidade sonora ${ }^{218}$. Entre 1968 e 1973 Rainforest passa por diversas adaptações de acordo com contextos diferentes de performance, até adquirir o formato de uma performance sonora mais complexa que envolve o uso de múltiplas estruturas definidas como "altofalantes esculturais" - objetos diversos aos quais são acoplados transdutores sonoros ${ }^{219}$ - e diversos intérpretes simultaneamente. Esta versão da peça passa a ser chamada retroativamente de Rainforest $I V$, a partir do lançamento em 1981 de uma gravação feita em uma das performances, e de sua instalação e realização em um festival em $1982^{220}$.

\footnotetext{
215 (COLLINS, 2004, p. 1)

216 (DRISCOLL; ROGALSKY, 2004, p. 26).

${ }^{217}$ Disponível em: < http://www.davidtudor.org/About/fsound.html>. Acesso em 30 de janeiro de 2018.

218 (DRISCOLL; ROGALSKY, 2004, p. 25-26)

219 (DRISCOLL; ROGALSKY, 2004, p. 28).

220 (DRISCOLL; ROGALSKY, 2004, p. 28).
} 
A performance que veio a ser Rainforest $I V$ se originou de uma oficina realizada por Tudor como parte de um festival em Chocorua, New Hampshire, em 1973, baseada nas experiências anteriores do compositor com montagem de circuitos para suas obras ${ }^{221}$. O processo de construção de circuitos e criação da performance deu origem a um coletivo denominado Composers Inside Electronics, responsável pela realização de diversas outras performances de Rainforest IV, mesmo após a morte de Tudor em $1996^{222}$. Também participaram como oficineiros do mesmo festival, em 1973, Gordon Mumma e David Behrman, compositores também associados a John Cage e ao coletivo Composers Inside Electronics.

A trajetória do holandês Michel Waisvisz (Leiden, 1949 - Amsterdam, 2008) possui alguns pontos em comum com Tudor e Ghazala, no sentido em que Waisvisz começou a desenvolver formas de interagir com circuitos analógicos de produção sonora tendo como base experiências empíricas de interferência em circuitos eletrônicos, como explorá-los com os dedos das mãos:

Em algum momento no começo dos anos 1960 eu comecei a tocar o interior do rádio de ondas curtas do meu pai [...] Meu irmão René e eu dávamos "concertos" em casa colocando os dedos nos circuitos ${ }^{223}$.

A interação física com circuitos eletrônicos através do toque se mostraria inspiradora para Waisvisz:

A grande vantagem é que ao tocar intuitivamente a eletrônica, era possível aprender a tocar este novo instrumento sem ter o conhecimento técnico do circuito - de forma bem semelhante a um instrumento musical tradicional ${ }^{224}$.

Este processo de tocar musicalmente circuitos eletrônicos teve início ainda nos anos 1960, com pequenas modificações em equipamentos eletrônicos diversos, e que culminou com a adaptação de um sintetizador comercial, o EMI VCS3, em cujo circuito Waisvisz instalou pontos de contato para que pudesse interagir com os o equipamento através do toque. Ao se associar com a fundação STEIM, a partir de 1973, Waisvisz colabora para uma mudança de perspectiva no trabalho de pesquisa e criação desta fundação, transitando gradualmente do foco na figura do compositor para uma ênfase nas possibilidades de performance sonora experimental, incluindo-se aí a abertura para uma participação do público, manipulando diretamente os circuitos eletrônicos utilizados para as apresentações ${ }^{225}$.

221 (DRISCOLL; ROGALSKY, 2004, p. 28).

222 (DRISCOLL; ROGALSKY, 2004, p. 29-30).

223 (WAISVISZ, 2004).

224 (WAISVISZ, 2004).

225 (WAISVISZ, 2004) 
A experimentação junto ao STEIM levou Waisvisz a desenvolver, ainda nos anos 1970, os projetos Crackle synth e Cracklebox, baseados neste princípio de interferência nos circuitos geradores de som por meio do toque. Este último projeto, Cracklebox, talvez pela sua simplicidade de execução, viria a ser muito influente na criação de instrumentos eletrônicos das gerações seguintes. Waisvisz desenvolve ainda, nos anos 1980, uma interface de controle inspirada no surgimento do protocolo MIDI, que permitia ao intérprete um nível de controle gestual mais sofisticado do que interfaces comuns construídas a partir de teclados de órgão convencionais. Este projeto, conhecido como The Hands estréia em 1984 - em um concerto em que a interface é utilizada para controlar um sintetizador Yamaha DX7 - e vai ser aprimorado por Waisvisz até sua morte em $2008^{226}$. O trabalho em conjunto com os engenheiros do STEIM envolvia uma negociação de limites estabelecidos no aspecto técnico:

Para fazer esta relação funcionar, eles tiveram que esquecer quase todo o "moralismo" tecnológico que lhes foi ensinado em sua educação ${ }^{227}$.

Uma referência importante no mapeamento das tendências no uso de eletrônica ao vivo discutidas nesta seção é o estadunidense Nicolas Collins, que também é autor de um método sobre Hardware Hacking e facilitador de oficinas sobre este tema, tendo uma produção extensa como compositor, construtor de instrumentos modificados e de sistemas de eletrônica ao vivo.

Assim como se observa com outros nomes citados acima, a produção de Collins exemplifica uma tendência na música experimental estadunidense na qual o compositor é o intérprete e criador de seus próprios instrumentos ${ }^{228}$, e que também agrega o improviso como elemento importante em sua abordagem composicional. Também é característico desta tendência um abandono dos instrumentos tradicionais e de sua "bagagem cultural", e o aprendizado prático através de publicações voltadas para eletrônica, oficinas - no caso de Collins, com Behrman e Tudor - e pela experimentação direta ${ }^{229}$ :

Meus instrumentos compartilhavam algumas características. Eles podiam ser tocados: seus sons podiam ser articulados em "tempo real" [...] Ao mesmo tempo, eles eram difíceis de controlar com precisão - os sons que a platéia ouvia eram mais o subproduto do processo em que o intérprete descobria o instrumento do que a articulação de um resultado pré-definido. ${ }^{230}$

${ }^{226}$ Disponível em: <http://www.crackle.org/TheHands.htm>. Acesso em 29 de maio de 2018.

227 (WAISVISZ, 2004)

228 (COLLINS, 2012, p. 29)

229 (COLLINS, 2008, p. 33)

230 (COLLINS, 2008, p. 33-34) 
Collins também descreve como a geração da qual faz parte acompanhou a introdução das tecnologias digitais no âmbito da música experimental, e detalha os processos envolvidos na criação de sistemas híbridos, como o de Eletrônica movida a trombone, construído em $1986^{231}$ e que encapsula características da eletrônica analógica com alguma flexibilidade do digital. Neste caso, um sistema híbrido foi montado na carcaça de um módulo de processamento de sinais, utilizando um computador Commodore64, e este sistema era controlado por um trombone modificado, no qual também foi acoplado um alto-falante que fazia o resultado sonoro do processamento soar através da tubulação do instrumento.

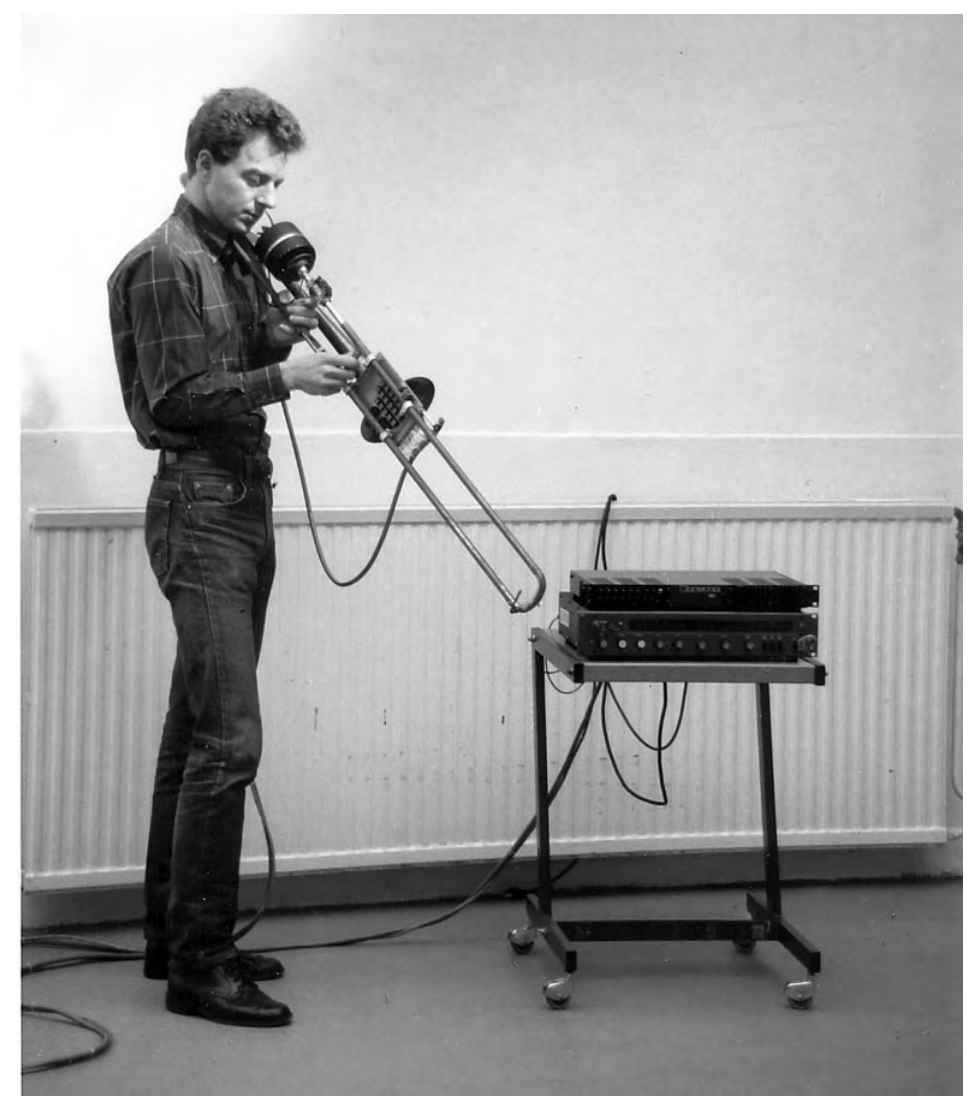

Figura 6 - Nicolas Collins e o sistema de Eletrônica movida a trombone. Foto: Acervo Nicolas collins.

Um ponto importante mencionado por Collins, e pouco discutido em outras narrativas sobre a introdução de ferramentas digitais, é que além do elemento gerador de som, o computador também encapsula aspectos da composição e da interpretação em seu sistema $^{232}$. Na passagem dos anos 1990 para os anos 2000, a consolidação do computador portátil como ferramenta de performance, além da sua ubiquidade no dia-a-dia e na produção de música em geral, estimula Collins a realizar oficinas de Hardware Hacking como uma forma de redescobrir potenciais deixados de lado em favor das novas tecnologia: "com o amadurecimento dos instrumentos musicais em um mercado em expansão, as 
idiossincrasias e as partituras embutidas nos circuitos e programações feitas em casa por artistas possibilitavam recursos mais flexíveis, mais amplamente aplicáveis e úteis". ${ }^{233}$. Duas máximas orientam o trabalho coletivo nestas oficinas: "Tudo o que vale a pena fazer, vale a pena fazer errado" e "dois erros podem resultar em um acerto"234

O livro Handmade Electronic Music 2006 é uma ferramenta pedagógica que surge como decorrência destas oficinas, mas também uma forma de documentar um processo histórico de criação de instrumentos voltada para o desenvolvimento de um repertório de música experimental feita com eletrônica ao vivo, sendo o próprio Collins pioneiro nesta empreitada ${ }^{235}$ :

Dissociar música e som dos tipos limitados de objeto vendidos em lojas de música, e, por meio desta dissociação, incitar novas descobertas musicais. Ao mesmo tempo, eu queria explorar as formas como esta novela da interação entre objeto e ideia se desenvolveu na música experimental nos últimos 50 anos [...] os projetos se propõe a relevar formas de manipulação e experiências que são fundamentalmente diferentes das simulações digitais e, dessa forma, inspiram uma relação diferente com o som e com o mundo material da eletrônica." 236

Esta abordagem em relação à construção e à manipulação de circuitos eletrônicos simples tem sido o cerne de manifestações coletivas nas últimas décadas, e tem inspirado também atividades em centros acadêmicos, como é o caso do grupo Dirty Electronics Ensemble, idealizado e coordenado pelo Dr. John Richards, na DeMontford University, no Reino Unido ${ }^{237}$.

\subsubsection{Luteria digital}

A partir dos anos 1980, uma confluência de diversos fatores faz com que a noção de utilizar computadores pessoas como instrumentos de performance em tempo real se torne viável, um processo em parte associado à prática individual de artistas envolvidos com o cenário de música experimental, como relatado por Collins (2009), e em parte ligado a centros acadêmicos de universidades nos Estados Unidos e na Europa ${ }^{238}$. Um ponto importante para a consolidação do uso de computadores na performance de música experimental dependeu, segundo Collins, do cruzamento de dois limiares importantes no início do século XXI:

233 (COLLINS, 2008, p. 35)

234 (COLLINS, 2008, p. 33)

235 (COLLINS, 2008, p. 37)

236 (COLLINS, 2008, p. 35-36)

237 Disponível em: < http://www.dirtyelectronics.org/>. Acesso em 29 de maio de 2018.

${ }^{238} \mathrm{O}$ autor faz um breve resumo da história da computação musical em (LIMA, 2013, p. 39-43) 
O poder de processamento e a velocidade das CPUs chegaram ao ponto em que máquinas acessíveis conseguiam processar áudio (e também vídeo) sem a necessidade de hardware dedicado e adicional; e este poder podia ser encolhido a ponto de caber em um pacote portátil" ${ }^{239}$

No ambiente digital a construção de instrumentos herda a ideia de modularidade que se observa na construção de instrumentos baseados em eletrônica analógica. No entanto, se no âmbito da eletrônica analógica a modularidade dos componentes do instrumento é um rompimento em relação ao conceito tradicional de instrumento musical, no ambiente digital esta questão se multiplica devido aos diversos estágios diferentes pelos quais o processo de criação de instrumentos se divide.

Uma parte substancial da literatura envolvendo a criação de instrumentos e interfaces de controle para interação com sistemas digitais é produzida na forma de artigos apresentados em congressos e periódicos, e devido às características do desenvolvimento tecnológico, muito desta produção não chega a ser reeditado em outros meios. Entre estes eventos destaco aqui a International Computer Music Conference, conferência anual da International Computer Music Association, organizada anualmente desde $1974^{240}$, e a conferência New Interfaces for Musical Expression, ou NIME, organizada anualmente desde 2001, e uma referência importante no que diz respeito a instrumentos musicais digitais e interfaces de controle ${ }^{241}$. Os trabalhos de Iazzetta (1996) e Jordà (2005) são referências importantes no que tocante ao detalhamento e análise do desenvolvimento de instrumentos musicais digitais e sistemas interativos.

\subsection{Pontos de análise - 1}

Neste capítulo busquei discutir a conceituação de instrumento musical tradicional e, através de algumas referências, mostrar que dentro da diversidade de práticas de luteria experimental às quais faço referência diversos aspectos sobre o conceito de instrumento musical afloram, aspectos estes que não estão ausentes se considerarmos instrumentos musicais tradicionais, mas que acredito poderem ser delineados e discutidos de forma mais clara tendo como ponto de partida a produção aqui pesquisada.

Nesta seção vou discutir três pontos que acredito serem importantes. O primeiro ponto é a noção de instrumento como mediador de uma práxis musical. O segundo ponto é uma aproximação da noção de inovação transetorial com a ideia de readymade. No terceiro

\footnotetext{
239 (COLLINS, 2009, p. 8)

240 Disponível em: < https://en.wikipedia.org/wiki/International_Computer_Music_Conference>. Acesso em 12 de fevereiro de 2018

${ }^{241} \mathrm{O}$ comitê permanente da conferência disponibiliza um banco de dados com os anais de todas as edições no endereço <http://www.nime.org/archives/>. Acesso em 10 de fevereiro de 2018
} 
ponto eu retomo o conceito de emaranhamento proposto por Salter para discutir algumas questões sobre as referências aqui estudadas.

Ainda que em narrativas como as de Russolo, Partch, Smetak, e também de alguns outros compositores-construtores, exista uma ênfase no sentido de o instrumento musical ser a materialização de um projeto estético e teórico sobre os rumos da música no tempo em que foram concebidos, acredito que seja possível olhar para esta relação a partir da perspectiva dos instrumentos, invertendo este vetor criativo. Desta forma, o exercício de olhar para os instrumentos como consequência das possibilidades materiais e técnicas disponíveis pode auxiliar no sentido de entender o quanto estes instrumentos informam os projetos estéticos aos quais estão integrados. Sem dúvida existe uma vontade criativa que orienta a construção de um instrumento como os intonarumori, mas as possibilidades técnicas e os materiais disponíveis que de fato são empregados em sua construção são tão impactantes ou mais no resultado final, e no tipo de música ou de arte sonora que é possível realizar com estes instrumentos ${ }^{242}$. Como ideia, o sintetizador modular dos anos 1960 existe pelo menos desde o Telharmonium de Calhill e o ensaio de Busoni, mas é uma combinação de disponibilidade material e viabilidade técnica que define os contornos deste instrumento, e a partir de sua existência no mundo percebe-se que o impacto que terá também está condicionado a uma rede complexa de influências.

Observo também que nos criadores em que o aspecto readymade e modular é mais presente, ainda que um estágio anterior de conceituação possa estar presente, há um certo abandono de projetos em favor de uma ênfase no processo, uma espécie de luteria experimental heurística em que o desenvolvimento de um instrumento é contínuo e fruto de uma articulação entre seu uso prático, sucessivas abstrações derivadas deste uso, e da forma como este instrumento vem a ser utilizado. Sobre este aspecto, Théberge (1997, p. 50) afirma: "um instrumento nunca está completo no estágio de design e construção; só se completa através de seu uso, normalmente de diversas formas e em diferentes contextos". O comentário de Théberge faz referência às criações do canadense Hugh Le Caine, em especial a Sacabuxa eletrônica, que encontrou diversos entraves no processo de se tornar um instrumento produzido em escala, o que não chegou a acontecer.

O papel do instrumento como mediador que viabiliza a experimentação musical e a performance também dá origem a um novo tipo de músico. Esta é uma característica que, acredito, transcende as abordagens propostas acima, sendo possível afirmar que o músico que existe a partir do contato com o instrumental de Smetak, assim como o músico que existe a partir da experimentação com dispositivos eletroeletrônicos, é um músico diferente daquele que se forma a partir de um instrumento tradicional e da execução de repertórios canônicos com este instrumento. Este novo personagem é um músico cuja

$\overline{242} \mathrm{Na}$ conclusão deste trabalho em 4 discuto mais extensamente esta relação, articulando-a com outras referências teóricas. 
formação não está prevista nos moldes tradicionais, sua relação com suas ferramentas e instrumentos de criação não está padronizada em currículos estabelecidos, e portanto o processo de aprendizado para construir suas ferramentas e para aprender a usá-las é o próprio aprendizado da criação sonora e musical. Esta é uma característica que se estende para casos além da eletrônica. É interessante notar que o aprendizado formal de Robert Moog não foi fundamental para aquilo que determinou sua produção, e sua formação como "criador de sintetizadores" se deu a partir de uma bricolagem epistemológica, de modo muito semelhante ao que ocorre com vários dos criadores aqui mencionados. Como consequência há a formação de comunidades de aprendizado, orientadas por um novo paradigma de relação com tecnologias, e por conseguinte a criação de bibliografias voltadas para os interesses destas comunidades.

Além do conhecimento compartilhado, também permeia esta produção uma relação que pode, em alguns aspectos, ser vista pela ótica da "inovação transetorial" como descrita por Théberge, que pode ser entendida como um tipo de ressignificação ou reaproveitamento em si mesma, mas também dialoga com a ideia de ressignificação e reaproveitamento inaugurada com o readymade em Duchamp, como discutido acima.

Por um lado, a noção de inovação transetorial já prevê o aproveitamento de tecnologias entre diferentes setores industriais, um modelo que se observa pelo menos desde a primeira revolução industrial e está presente em todas as etapas do desenvolvimento tecnológico desde então, o surgimento de novas tecnologias e seu aproveitamento e adaptação para usos não necessariamente previstos quando da sua introdução, estas são condições que sem dúvida criam limiares da invenção a cada geração. Por outro lado, o processo de inovação tecnológica inevitavelmente está atrelado a um processo de descarte de tecnologias mais antigas, ainda que estas não estejam obsoletas, e neste descarte também germinam outros limiares possíveis. Diferentes autores voltam para esta questão, e como veremos adiante este também é um tópico que aparece na produção brasileira.

A questão da relação entre corpo e mediação tecnológica na performance musical é uma discussão constante que por vezes toma um novo fôlego em virtude da adoção de novas tecnologias e, ao observarmos a narrativa histórica proposta por Salter, observamos que a importância do corpo ressurge de tempos em tempos como resposta a momentos em que determinadas tendências manifestam uma atitude performativa que requer pouco engajamento do corpo humano. Salter (2010, p. 217) exemplifica esta questão fazendo um paralelo entre a música sem intérpretes da era dos concertos de música acusmática e tape music nos anos 1950 e 1960, e a era da laptop music no final dos anos 1990 e início do século XXI. Esta também é uma questão que surge em outros contextos em relação ao esforço físico, como por exemplo no surgimento da música pop produzida eletronicamente nos anos 1970 e 1980, e atualmente em relação à figura do DJ como celebridade musical.

O conceito de emaranhamento proposto por Salter parece ser adequado para 
analizar algumas propostas citadas acima que buscam um outro tipo de inserção do corpo em relação à música e ao som mediados eletronicamente, como por exemplo a ideia de BEAsape descrita por Ghazala (2004, p. 101) - acrônimo para BioElectronicAudiosapian, que pode ser traduzido vagamente como "ser audiosenciente bioeletrônico" - como o emaranhamento de instrumento e intérprete em um ser sonoro musical por meio da corrente elétrica, no qual os limiares entre seus componentes ficam menos definidos. Motivação semelhante é observada na forma como Collins descreve sua opção por utilizar diversos intérpretes interagindo com um circuito eletrônico em sua peça Salvage (Guiyu Blues): "eu preciso de 12 mãos para tocar essa peça. Não dá pra colocar 12 pontas de prova em dois pares de mãos e chegar na mesma textura, pois não dá pra mexê-las com o mesmo grau de independência" 243 . Na peça em questão, 6 intérpretes manipulam pontas de prova sobre uma placa de circuito impresso descartada, acionando um circuito eletrônico com 6 osciladores simples, cuja saída - juntamente com as imagens de uma webcam, posicionada sobre as mãos dos intérpretes e a placa de circuito impresso - é controlada por um sétimo intérprete, que também coordena a ação dos outros seis participantes.

Acredito que obras como Salvage, Rainforest e conceitos como BEAsape são exemplos válidos para demonstrar a possibilidade de emaranhamento e do cruzamento de limiares entre papéis estabelecidos de obra-instrumento-intérprete no contexto da performance musical. Também acredito ser possível aproximar este conceito daquilo que Raaijmakers descreve como aglomerado de valores para entender instrumentos eletroeletrônicos:

Geradores elétricos [de som] não podem de fato ser comparados a "corpos" ressonantes em instrumentos musicais. Eles são 'aglomerados de valores' que não podem ser entendidos por suas ações, mas pelo resultado destas ações. O fato de que isso se torna possível graças à eletricidade envolve tais instrumentos em um mistério profundo 244

O conceito de aglomerado de valores para descrever instrumentos eletroeletrônicos pode indicar uma forma mais adequada para lidar com estes instrumentos do que o mero entendimento do seu modo de funcionamento, ou da lógica técnica que estrutura estes instrumentos. Para Raaijmakers(2000, p. 16), o som circuito de um instrumento eletrônico é imaterial, infatigável e atemporal, e é a articulação por meio do intérprete que vai dar sentido a esta produção sonora. A partir da sugestão de Raaijmakers podemos também olhar para esta noção de aglomerado a partir do aspecto material, enquanto aglomerado de materiais e processos técnicos que fazem com que aquele instrumento exista e esteja disponível para execução. Além do instrumento em si, há toda uma cadeia de condições materiais externos a este instrumento e a seu intérprete, que também se fazem audíveis

\footnotetext{
$\overline{{ }^{243} \text { Collins apud (FERNANDEZ; LIMA, }}$ 2016, p. 18). A partitura da peça está disponível em: <http: //nicolascollins.com/texts/salvagescore.pdf > . Acesso em 28 de maio de 2018.

244 (RAAIJMAKERS, 2000, p. 17)
} 
através deste aglomerado de valores, um emaranhamento de conceitos e possibilidades informados por estes materiais, por suas capacidades e limitações, e pela forma como estão organizados neste instrumento específico. 


\section{Cena brasileira contemporânea}

Neste capítulo o objetivo é esboçar um panorama das práticas de luteria experimental no Brasil, e das relações desta prática com o cenário de música experimental atual. Na seção 2.1 são discutidos os trabalhos de Pinto (2002), Fernandez (2013) e Obici (2014), devido à relação que estes possuem com o tema desta pesquisa e ao levantamento de artistas e obras feito por estes autores. Complementam esta seção referências a outros autores que também abordam temas relacionados com esta pesquisa.

Nas seções 2.2 e 2.3 busco esboçar um panorama do cenário de música experimental contemporâneo no Brasil, com ênfase em aspectos deste cenário que tenham relação com práticas de luteria experimental. A pesquisa para estas seções se deu a partir de levantamentos já realizados - como os feitos em Fernandez (2013), Obici (2014) e Scarassatti (2008 e 2015), além de outros autores como Lima (2013), Miskalo (2014) - e também através de pesquisas na Internet, conversas e entrevistas com os artistas citados, e pela visitação e participação em eventos relacionados com o tema. Em alguns casos, em particular na seção 2.3, destaco alguns projetos realizados como forma de apresentar procedimentos e escolhas feitas pelos artistas citados. A escolha dos projetos citados nesta seção também foi influenciada pela disponibilidade de informações sobre estes projetos específicos.

Por fim, na seção 2.4 são feitas algumas análises preliminares sobre as referências citadas e sobre este levantamento, e a relação destes com o tema desta pesquisa.

\subsection{Referências}

Theophilo Pinto (2002) desenvolve uma pesquisa sobre a fabricação de instrumentos eletrônicos no Brasil no período situado entre os anos 1960 e meados dos anos 1990, com ênfase no trabalho de desenvolvimento de tecnologia e na criação de projetos para instrumentos musicais desenvolvido por alguns agentes em particular:

Jorge Antunes Nascido no Rio de Janeiro em 1942, Antunes é bastante conhecido por sua atuação como compositor, sendo considerado um dos pioneiros da música eletroacústica no Brasil ${ }^{1}$. Tendo formação como radiotécnico e posteriormente formação acadêmica em Música e Física² ${ }^{2}$ Antunes construiu nos anos 1960 alguns equipamentos voltados para a produção de música eletroacústica, como um gerador de ondas no formato dente-de-serra (1961), um reverberador de mola (1962) e dois Theremins,

1 Disponível em: <https://www.latinoamerica-musica.net/bio/antunes.html>. Acesso em 4 de março de 2017.

2 Disponível em: <http://lattes.cnpq.br/9108415300636127>. Acesso em 04 de março de 2017. 
um valvulado em 1963 e outro transistorizado em 1965³ . Cabe adicionar a título de curiosidade, no que tange à luteria experimental, a construção em 1963 de um violino feito inteiramente de palitos e caixas de fósforo ${ }^{4}$.

Clomildo Suette Nascido em 1944, Suette atuou como músico popular desde os anos 1950 tocando acordeom e diversos instrumentos de teclado. Com formação em radiotécnica, desenvolveu entre meados dos anos 1970 e o começo dos anos 1980 instrumentos baseados nos modelos de piano elétrico, ambos de fabricação estadunidense, Wurlitzer ${ }^{5}$ e Fender Rhodes ${ }^{6}$ : uma versão reduzida criada para substituir o contrabaixo, semelhante ao instrumento Piano Bass, também fabricado pela Rhodes; e um piano elétrico completo. Este último, que recebeu o nome de Piano Suette, foi fabricado em série entre 1981 e o início dos anos 1990 (PINTO, 2002, p. 44-50).

CCDB Cláudio Cesar Dias Baptista, nascido em São Paulo em 1945, desenvolveu de forma autodidata um vasto conhecimento sobre eletrônica e tecnologias relacionadas com áudio e acústica. Entre os anos 1960 e os anos 1990 projetou diversos instrumentos musicais, muitos deles utilizados pela banda Os Mutantes, da qual faziam parte seus irmãos mais novos Arnaldo e Sérgio, e equipamentos de áudio como amplificadores, processadores e mesas de mixagem ${ }^{7}$. CCDB também construiu um sintetizador analógico (1975), instrumento este que deu origem a uma série de artigos publicados na Revista Nova Eletrônica entre 1977 e 1984 ${ }^{8}$, nos quais cobriu não só a construção deste instrumento mas também diversos tópicos relacionados com áudio e eletrônica. Entre os anos 1980 e 1993 chegou a produzir em série alguns de seus modelos de equipamentos de áudio ${ }^{9}$, tendo abandonado gradualmente esta produção ao longo da segunda metade dos anos $1990^{10}$.

Guido Stolfi Nascido em São Paulo em $1953^{11}$ e com formação acadêmica em Engenharia Eletrônica pela Universidade de São Paulo ${ }^{12}$, Stolfi construiu entre 1974 a 1975 o

3 (PINTO, 2002, p. 107-110)

4 Disponível em: < https://vimeo.com/29061180> e <http://rabeca.org/?fd=240>. Acesso em 4 de março de 2017.

5 Disponível em: < https://en.wikipedia.org/wiki/Wurlitzer_electric_piano>. Acesso em 4 de março de 2017.

6 Disponível em: <https://en.wikipedia.org/wiki/Rhodes_piano>

7 (PINTO, 2002, p. 50-58)

8 (PINTO, 2002, p. 144)

9 (PINTO, 2002, p. 55-58)

10 Nota do autor: Pinto (2002, p. 58) cita o ano de 1994 como o final das atividades de CCDB como construtor de equipamentos eletrônicos. No entanto, eu pessoalmente acompanhei o processo de encomenda e compra de um amplificador Turbo-Compressor feito por CCDB entre 1999 e 2000, encomendado por Márcio Alencar, contrabaixista atuante na cena musical da cidade de Recife desde os anos 1990. O próprio CCDB cuidou de toda a comunicação ao longo do processo, construiu o equipamento sob encomenda e gravou um vídeo instruindo o comprador a como usar o equipamento corretamente.

11 Disponível em: <http://www.guiadosquadrinhos.com/artista/guido-stolfi-gus/7717>. Acesso em 4 de março de 2017

12 Disponível em: <http://www.lcs.poli.usp.br/ gstolfi/>. Acesso em 4 de março de 2017 
Sintetizador Modular Digital ${ }^{13}$, um sintetizador híbrido que se utilizava de eletrônica analógica e digital, controlável por computador ${ }^{14}$. Também desenvolveu ao longo dos anos 1980 um sampler digital, o Papagaio ${ }^{15}$, para a produtora Norte Magnético, de Luiz Roberto de Oliveira.

Ricardo Peculis Engenheiro eletrônico nascido em Santos, Peculis criou dois protótipos de sintetizadores analógicos monofônicos - o primeiro entre 1977 e 1978 e o segundo em 1980 - um sintetizador híbrido polifônico em 1983 e um sintetizador digital em 1988, desenvolvido para ser utilizado juntamente com um computador MSX, bastante popular no Brasil na época ${ }^{16}$. Nenhum de seus projetos chegou a ser produzido em série, apesar de seu criador ter buscado parcerias para este fim.

Ivan Seiler Nascido em Ourinhos em 1956, Seiler possui formação técnica em eletrônica e desenvolveu no final dos anos 1970 um sintetizador monofônico, do qual vendeu três unidades em 1979. Nos anos 1980 projetou e construiu um sintetizador modular polifônico que não foi além do protótipo, mas que colaborou para a criação de uma bateria eletrônica, a DigiDrum, semelhante aos instrumentos fabricados pela empresa britânica Simmons ${ }^{17}$, da qual foram fabricadas e vendidas cerca de 500 unidades ${ }^{18}$. Seiler também desenvolveu outros produtos com algum sucesso comercial, como transmissores sem fio para guitarras e baixos elétricos, e também interfaces e caixas de roteamento de sinais no protocolo MIDI.

Instrumentos Giannini Fundada em 1900, a Giannini é uma das marcas mais estabelecidas no mercado de instrumentos musicais no Brasil, com foco principalmente em instrumentos de corda, assim como na fabricação de encordoamentos. Seu envolvimento com equipamentos eletrônicos deu-se a partir de 1955, quando começa a fabricar violões elétricos, e ao longo das décadas seguintes a marca produz guitarras e baixos elétricos, amplificadores e pedais de efeito para estes instrumentos, órgãos eletrônicos, pianos elétricos e inclusive um sintetizador digital produzido em parceria com a marca italiana Siel ${ }^{19}$, o GS-7010, produzido em 1987 e que foi introduzido pela Siel nos mercados norte-americano e europeu com o nome de DK-70 20. A partir dos anos 1990, devido a mudanças econômicas e de política tarifária para importações no Brasil, a Giannini deixa de desenvolver projetos em eletrônica e volta a concentrar-se na fabricação de instrumentos acústicos, e guitarras e baixos elétricos.

$\overline{13}$ Informações e imagens deste instrumento também estão disponíveis em < http://www.lcs.poli.usp.br/ $\sim$ gstolfi/PPT/Audio_GS.pdf>. Acesso em 4 de março de 2017.

14 (PINTO, 2002, p. 111-116)

15 (PINTO, 2002, p. 132)

16 (PINTO, 2002, p. 67-69)

17 Disponível em: < https://en.wikipedia.org/wiki/Simmons_(electronic_drum_company)>. Acesso em 4 de março de 2017

18 (PINTO, 2002, p. 70-73)

19 A Siel - Società Industrie Elettroniche - produziu outros modelos de sintetizador além da parceria com a Giannini, que podem ser vistos em: <http://siel.sendex.nl>. Acesso em 11 de março de 2017.

20 (PINTO, 2002, p. 80-85) e (PINTO, 2002, p. 172). Mais informações sobre o instrumento disponíveis em: <http://www.vintagesynth.com/misc/sieldk70.php>. Acesso em 11 de março de 2017. 
Apesar de, nos estudos de caso mencionados por Pinto, a intenção destes criadores ter sido emular ou aperfeiçoar modelos já existentes de instrumentos e equipamentos eletrônicos, visando no mais das vezes uma produção em série para competir com a escassa oferta de equipamentos disponível no Brasil no período pesquisado, sua pesquisa delineia as condições sócio-econômicas e culturais que estabeleceram o cenário no qual a maioria dos casos estudados no presente trabalho se desenvolveu. De fato, a continuidade dos projetos citados por Pinto foi limitada pelas condições econômicas, sociais, e pela impossibilidade de acompanhar em nível industrial os rumos da produção de instrumentos musicais eletrônicos e de equipamentos de áudio em relação ao mercado internacional, e esta realidade teve algum impacto tanto nos agentes citados adiante que começaram a desenvolver seus trabalhos ainda nos anos 1980 e 1990, quanto nos que começaram seus trabalhos nas últimas duas décadas.

Sobre este aspecto Pinto (2002, p. 187-200) chama a atenção para a forma como as políticas alfandegárias impactaram o mercado de instrumentos musicais no Brasil, e também o mercado de tecnologia em geral. Durante a maior parte do período estudado, as alíquotas de importação sujeitavam o processo de importação a custos quase proibitivos, de modo que a prática do contrabando era bastante difundida no setor ${ }^{21}$. A política alfandegária neste período, em teoria, seria uma forma de alavancar a produção nacional de tecnologia e bens de consumo, mas na prática a dificuldade de acesso a equipamentos eletrônicos produzidos fora do país serviu como impedimento para que novas tecnologias desenvolvidas no Brasil fossem aplicadas em escala industrial, e em alguns casos ajudou a inibir este desenvolvimento. No tocante a projetos destinados à fabricação em larga escala o resultado é que grande parte da produção nacional acabou buscando emular modelos já existentes no exterior, sem necessariamente agregar elementos inovadores propostos por criadores brasileiros, salvo raras exceções. Os processos de mudança nas políticas alfandegárias no Brasil, associado ao fenômeno da globalização em âmbito internacional, colaboraram para uma mudança neste cenário a partir dos anos $1990^{22}$.

Pinto também descreve a contribuição de outros agentes na criação de cursos especializados em síntese sonora - como os cursos realizados no Museu de Arte de São Paulo em 1975 e 1976, organizados por Luiz Roberto de Oliveira ${ }^{23}$, e os cursos da escola Núcleo Synthesis, existente entre 1985 e 1989 e criada por Conrado Silva, Jorge Poulsen e Lucas Shirahata ${ }^{24}$ - e o impacto que publicações voltadas para o público hobbista interessado em eletrônica teve no surgimento de iniciativas nacionais na construção de instrumentos eletrônicos. De fato, dos criadores mencionados por Pinto, todos tiveram uma espécie de "formação complementar autodidata" feita a partir de revistas, periódicos e outras 
publicações que traziam para o público os diagramas, esquemas, listas de componentes e demais instruções necessárias para a montagem de equipamentos eletrônicos simples direcionados para a produção de sons, sejam estes instrumentos completos como o Theremin ou um sintetizador simples, sejam complementos como pedais de efeito ou módulos de um sintetizador maior. Este processo - a formação de um público consumidor, mas que também tem interesse na construção de equipamentos a partir do acesso aos meios hábeis de se fazer algo - que vai estar associado a produção de música mediada tecnologicamente.

O nome de George Romano também é citado por Pinto (2002, p. 75, 87-88). Romano esteve envolvido no desenvolvimento do piano elétrico Yendis, fabricado por Sidney Paretti ${ }^{25}$, dos órgãos Gambitt, além de produzir órgãos eletrônicos em fábricas próprias e ter projetado uma bateria eletrônica "de dedo" muito popular nos anos 1980 . Voltarei ao nome de Romano no item 3.3.1.

Fernandez (2013) analisa práticas de criação musical baseadas naquilo que chama de Circuito Alterado, termo proposto por Fernandez para abarcar as duas tendências dentro do universo de modificação e criação de aparelhos sonoros eletrônicos de baixa voltagem citadas no capítulo anterior ${ }^{26}$, Circuit Bending e Hardware Hacking. O trabalho de Fernandez levanta, a partir do cenário do Circuito Alterado, alguns pontos que também permeiam o cenário de luteria experimental, ambos cenários apresentando várias intersecções entre si no tocante a artistas, espaços e eventos em que estas práticas artísticas são realizadas.

O primeiro ponto diz respeito a um resgate do elemento lúdico na prática musical: o processo de alteração de circuitos é desenvolvido como um jogo, uma experiência lúdica em que o alterador não só explora o circuito que deseja alterar, mas também joga com papéis estabelecidos dentro de práticas musicais tradicionais. Explorar aparelhos sonoros é brincar com suas intenções originais:

"O alterador, neste jogo, procura desprogramar o aparelho, visando extrair dele sons que não deveriam estar ali, buscando que o aparelho soe de forma mais interessante do que ele foi programado originalmente para soar" 27 .

Neste processo está implicada uma transgressão às convenções que acompanham a performance tradicional de música, abrindo-se espaço para a "atuação de intérpretes que não passaram por um longo processo de formação, facilitando a atuação de músicos amadores, ou mesmo de indivíduos que não possuam um aprendizado formal de música"28.

O segundo ponto levantado por Fernandez diz respeito a um resgate, na cena de

\footnotetext{
25 Disponível em: <http://www.musitec.com.br/revistas/?c=132>. Acesso em 1 de fevereiro de 2018.

26 Ver itens 1.3 .2 e 1.4 .2

27 (FERNANDEZ, 2013, p. 62)

28 (IAZZETTA, 2011, p. 5)
} 
Circuito Alterado, de práticas artesanais e de uma exploração empírica materializada no espírito Do-It-Yourself. A noção de DIY tem relação com a criação e construção de móveis, aparelhos eletrônicos, brinquedos e demais bens de consumo - que no contexto das sociedades industrializadas normalmente são produzidos industrialmente e comercializados em larga escala - por indivíduos ou grupos de indivíduos em caráter amadorístico ou hobbista. Nos anos 1970, a cultura DIY passa a ser associada com uma produção artística que busca questionar o mainstream cultural, como uma resposta aos anseios criativos de alguns setores da população que se manifesta em contextos como o movimento punk, pós-punk e de música industrial na Europa e nos Estados Unidos ${ }^{29}$. Fernandez (2013, p. 88) aponta que partir deste momento histórico, a noção de DIY pode ser entendida como a combinação de três estados, "um político / ideológico, sendo uma revolta contra a ordem mercadológica hegemônica; um industrial, sendo uma busca de novas formas de produção, fora da cultura de massa; e um estético, relacionado com a busca de formas singulares de expressão".

Iazzetta (2011, p. 7) destaca que esta postura encontra ressonância em diversas frentes de produção musical nas últimas décadas, desde a produção fonográfica caseira, voltada para diversos gêneros da música popular urbana, até o surgimento de gêneros como o cenário da laptop music e das práticas de alteração de circuitos.

O terceiro ponto destaca que, para além do faça-você-mesmo, há uma busca por uma coletividade. Um elemento constituinte no cenário das práticas de Circuito Alterado é a busca por um compartilhamento de saberes e pela multiplicação destas iniciativas. Este fator de multiplicação se manifesta por três vias: concertos e apresentações públicas; oficinas; e divulgação, principalmente pela internet ${ }^{30}$, e o trabalho de Fernandez se concentra nas duas primeiras, levando em conta que a noção de performance não está presente somente nas apresentações públicas, mas também no espaço da oficina ${ }^{31}$.

A noção de uma prática realizada em comunidade é parte estrutural do desenvolvimento desta cena musical, uma característica que, segundo o autor, tem relação com um processo de "transindividuação" 32, de aprendizado e transformação coletivos entre os participantes do ambiente da oficina e da performance. Neste contexto, a ideia de uma produção focada no Do-It-Yourself passa a ser orientada pela ideia de Do-It-With-Others (DIWO) ou ainda Do-It-Together (DIT), "fazer com outros" ou "fazer em conjunto"33.

Neste aspecto coletivo, chamo a atenção para um ponto em comum com os estudos de caso no trabalho de Pinto (2002) e ao fenômeno dos grupos de usuários mencionados por Thèberge (1997), ambos citados anteriormente. Ainda que os motivos aparentes sejam

29 (FERNANDEZ, 2013, p. 87)

30 (FERNANDEZ, 2013, p. 99)

31 (FERNANDEZ, 2013, p. 115)

32 (FERNANDEZ, 2013, p. 111)

33 (FERNANDEZ, 2013, p. 113) 
diferentes, o fenômeno de surgimento de uma comunidade ao redor do interesse mútuo pelo aprendizado a respeito de um conjunto de tecnologias aplicadas é comum aos cenários descritos, e é parte integrante do aprendizado e da prática musical das pessoas envolvidas.

Sobre o registro e divulgação online, cabe aqui um aparte para comentar sobre o caráter efêmero deste tipo de registro. Durante a realização desta pesquisa, vários dos websites mencionados na literatura pesquisada já se encontravam fora do ar. Através de recursos como o Wayback Machine ${ }^{34}$, uma iniciativa da organização Internet Archive ${ }^{35}$, é possível acessar parte deste conteúdo, mas elementos importantes como arquivos de áudio e de vídeo normalmente não são arquivados, sendo possível somente acessar o texto publicado nestas páginas. Essa constatação pode ser analisada de duas formas: por um lado, é lamentável que os registros disponíveis de toda uma produção em um período relativamente amplo não esteja mais disponível de forma tão acessível quanto já esteve. Por outro lado, não se pode deixar de entender esse fato como um sinal de que esta produção técnica e musical não preza necessariamente por uma longevidade, visto que não há uma preocupação em manter estes registros "no ar". É possível especular que os responsáveis por estas iniciativas não estejam muito preocupados com o estabelecimento e com a manutenção de uma tradição relacionada a estas práticas.

A análise de Obici se estrutura de a partir do conceito de Gambiarra, construído a partir de um levantamento das origens do termo, suas diferentes aplicações no vernáculo e, como elemento fundamental no trabalho de Obici, das apropriações deste termo no contexto da criação artística, em especial nas relações entre criação mediada tecnologicamente. Sobre o termo em si, a definição de trabalho de Obici em seu trabalho pode ser resumida como uma "saída técnica que se vale dos meios disponíveis"36.

Dessa forma, Obici (2014, p. 51-93) propõe aproximações entre seu conceito de gambiarra com diversos momentos e movimentos artísticos nos quais práticas de reutilização de materiais e referências: "práticas artísticas que permeiam o dadaísmo, tais como o ready made, os procedimentos de reapropriação de materiais ao modo do Merz, e o remix, mash up, collage e mesmo a bricolagem" 37 . Neste contexto, o termo Gambiarra surge como uma espécie de guarda-chuva, sendo utilizado a partir dos anos 2000 no contexto de textos críticos e análises sobre a produção artística, em especial sobre a produção brasileira ${ }^{38}$, e o enfoque de Obici em seu trabalho delimita"práticas que dialogam com a concepção de luteria e/ou design de instrumentos musicais"39 ou, como propõe, Gambioluteria ${ }^{40}$.

Dentre os pontos levantados por Obici em relação a essa produção, destaco a

${ }_{34}$ Disponível em: <https://en.wikipedia.org/wiki/Wayback_Machine>. Acesso em 7 de Março de 2017.

35 Disponível em: < http://archive.org/web/>. Acesso em 7 de Março de 2017

36 (OBICI, 2014, p. 10)

37 (OBICI, 2014, p. 53)

38 (OBICI, 2014, p. 52)

39 (OBICI, 2014, p. 3)

40 (OBICI, 2014, p. 169) 
seguir alguns que se aproximam dos temas do presente trabalho de pesquisa. O primeiro ponto é uma aproximação proposta por Obici entre a noção de Gambiarra e a noção de Desobediência Tecnológica proposta pelo artista e pesquisador cubano Ernesto Oroza: "um desrespeito crescente pela identidade do objeto, e pela verdade e autoridade que este incorpora" ${ }^{41}$. A perspectiva de Oroza é a do reaproveitamento de materiais em Cuba, com maior ênfase no chamado Período Especial, durante o qual a provisão de bens tecnológicos e outros bens de uso comum é suspensa devido ao final da União Soviética ${ }^{42}$. No entanto, a necessidade de suprir carências tecnológicas em Cuba remonta aos anos 1960, tendo influenciado na criação de um comitê e posteriormente uma associação nacional cujo objetivo principal era desenvolver soluções tecnológicas para manter a indústria local funcionando apesar dos embargos comerciais impostos pelos EUA e pela saída do país de diversos técnicos, engenheiros e trabalhadores qualificados ${ }^{43}$.

Oroza argumenta que esta atitude de desobediência questiona a lógica tecnológica e de consumo dos objetos industriais a partir da perspectiva artesanal, à medida que os objetos industriais são dissecados e reaproveitados a partir das necessidades de um contexto sócio-político-geográfico diferente daquele em que tais objetos são criados, numa abordagem que tem como base a criatividade de seus usuários. Sob esta perspectiva, o objeto industrial é destituído de seu status como objeto acabado e pode ser visto como matéria-objeto, uma nova forma de matéria-prima para a compilação de novos aparatos ${ }^{44}$, através de uma crítica artesanal ao objeto industrial.

Em um contexto político e econômico diferente, a situação de escassez de recursos é semelhante no Brasil, como foi mencionado anteriormente sobre o trabalho de Pinto, e por outro lado, o país também passou por períodos de uma súbita abundância de bens de consumo eletrônicos, notadamente a partir dos anos 1990 da mudança das políticas tarifárias em relação à importação destes produtos ${ }^{45}$.

Num sentido mais amplo e atual, a noção de desobediência tecnológica pode ser entendida como um modo de lidar com as questões de sustentabilidade ecológica, com escassez de recursos mas também com o excesso de recursos e o consumo destes recursos através de estratégias de mercado como a obsolescência programada. Este último ponto também é trazido por Fernandez (2013, p. 31), que define esta estratégia como o "metaprograma de nossa sociedade de consumo" 46 , um contexto no qual a desobediência tecnológica ou a gambiarra podem ser vistas como "um comportamento emergente desse ecossistema, que lida com soluções não convencionais, passando a abranger um espectro

41 (ROGNOLI; OROZA, 2015)

42 Disponível em: < https://es.wikipedia.org/wiki/Per\%C3\%ADodo_especial>. Acesso em 21 de março de 2017.

43 (OROZA, 2012)

44 (OROZA, 2012)

45 (PINTO, 2002, p. 198)

46 (FERNANDEZ, 2013, p. 32) 
de aplicações e usos relacionados ao contexto de uma cultura mediada pela tecnologia" 47 .

Outro ponto em comum entre Obici e Fernandez está no reconhecimento do improviso como estratégia de aprendizado e construção de saberes, "enquanto ação empírica informal, oposta ao formalismo teórico do saber"48, e do aspecto lúdico integral às praticas tanto de gambioluteria quanto de alteração de circuitos. Naturalmente, esta coincidência se dá em parte devido ao fato de ambos autores se debruçarem sobre alguns artistas em comum, mas estas características em comum podem ser percebidas tanto em artistas que praticam uma gambioluteria sem o uso de circuitos eletrônicos, quanto com artistas de circuito alterado fora do contexto brasileiro.

Como mencionado acima, Fernandez, Obici e Scarassatti também realizam levantamentos de artistas cujas atividades se relacionem com as pesquisas destes autores. Em seu livro Walter Smetak: O alquimista dos sons, Scarassatti (2008, p. 138-139) relaciona uma série de artistas que, de uma forma ou de outra, "ressoam as experiências" de Smetak, ainda que não necessariamente tenham tido contato direto com a sua obra: Marco Antônio Guimarães e grupo Uakti, Fernando Sardo, Marcelo Petraglia, Carusto Camargo, Wilson Sukorski, Paulo Nenflídio, Lívio Tragtenberg e o coletivo Chelpa Ferro.

Na forma de Apêndice, Fernandez (2013, p. 150-171) apresenta um mapeamento de diversos artistas e coletivos dedicados à prática do circuito alterado, assim como de espaços onde estas práticas ocorrem, muitos dos quais brasileiros: DaDa Attack, Coletivo Gambiologia, Henrique Iwao, Rede Metareciclagem, Duo N-1, Orquestra Organismo, Pan\&Tone, Tony da Gatorra e Garoa Hacker Clube

O levantamento em Obici (2014, p. 94-166) tem foco no cenário brasileiro de arte sonora e música experimental. Além de artistas já mencionados - Smetak, Guimarães e Uakti, Sukorski, Chelpa Ferro, Coletivo Gambiologia, Nenflidio, Duo N-1, Pan\&Tone e Tony da Gatorra - Obici também explora a produção de Marco Scarassatti, Tato Taborda, e do duo O Grivo. Obici (2014, p. 111) também faz menção aos experimentos do cantor e compositor Tom Zé com a construção de instrumentos em uma abordagem readymade, a partir de utensílios domésticos ${ }^{49}$

No texto Instrumentarium: dispositivos e contradispositivos no instrumentário brasileiro dos últimos $100 \operatorname{anos}^{50}$, Scarassatti parte de uma introdução histórica mencionando, por exemplo, os instrumentos de percussão introduzidos por VillaLobos na orquestra sinfônica para a execução de suas obras, o contraste entre a geração

47 (OBICI, 2014, p. 10)

48 (OBICI, 2014, p. 11)

49 Como a obra de Tom Zé é relativamente mais bem documentada do que as dos demais artistas aqui pesquisados, e também por não ter encontrado muita ressonância do trabalho de Tom Zé neste sentido, talvez por estar inscrito em um repertório musical mais tradicionalista como o da MPB, não me aprofundarei neste aspecto de sua obra no presente trabalho.

50 (SCARASSATI, 2015) 
deste compositor e a geração seguinte, a primeira geração de compositores no Brasil a lidar criativamente com os recursos eletroeletrônicos, e também a obra de Smetak, para apresentar um panorama composto por artistas que lidam com diferentes tipos de instrumentário. O panorama esboçado por Scarassatti não se limita a artistas que criem instrumentos físicos, incluindo compositores de música de concerto com instrumentos tradicionais, instrumentos preparados ou expandidos, e compositores de música eletrônica e eletroacústica, como Guilherme Vaz ${ }^{51}$, Rodolfo Caesar, Alexandre Lunsqui, Guilherme Antônio Ferreira, Valério Fiel da Costa, Jean-Pierre Caron e Mário del Nunzio. Além dos já citados Iwao, Tragtenberg, dos integrantes do Duo n-1, Sukorski, Taborda, O Grivo e Nenflídio, também é explorada a produção de Eduardo Néspoli. A noção de dispositivo utilizada por Scarassatti neste texto para discutir esta produção também será retomada adiante.

Na seção 2.3 analiso a obra de alguns destes artistas, acrescentando também outros nomes encontrados ao longo desta pesquisa que possuem relação com este processo de construção de instrumentos. Como mencionado na introdução, mantive a abrangência da minha pesquisa limitada à produção que lida com instrumentos físicos e artistas que trabalham com manipulação de circuitos e / ou com o limiar entre a eletrônica analógica e o uso de linguagens de programação, não me aprofundando no trabalho criativo e composicional desenvolvido apenas em ambientes digitais. Como objeto para um estudo de caso mais profundo, escolhi tratar de Tony da Gatorra, e mais especificamente de seu instrumento, a gatorra, no próximo capítulo.

\subsection{Espaços e eventos}

\subsubsection{Ibrasotope}

O Ibrasotope é um "núcleo que se dedica à produção e difusão de música experimental" 52 , fundado por Mário Del Nunzio e Henrique Iwao ${ }^{53}$ em 2007 e sediado em São Paulo, em uma casa no bairro Vila Nova Conceição. Sua criação está relacionada com uma série de atividades que têm início a partir de 2002 organizadas por alunos de composição da UNICAMP, entre concertos, reuniões e debates ${ }^{54}$, das quais também resulta a realização

\footnotetext{
51 Vaz estudou nos Seminários de Música da UFBA, e menciona ter estudado luteria com Smetak, mas não encontrei registros de sua produção no tocante a instrumentos propriamente ditos. Em 2007, Vaz utiliza instrumentos feitos por Smetak para o disco "Vento Sem Mestre". CENTRO CULTURAL BANCO DO BRASIL. Guilherme Vaz: Uma fração do infinito. Rio de Janeiro, 2016. 320 p. Catálogo da exposição. 12 de janeiro a 4 abril de 2016

52 Disponível em: < https://ibrasotope.wordpress.com>. Acesso em 09 de janeiro de 2017.

53 (SILVEIRA; NUNZIO, 2008, p. 4)

54 Entre os nomes mencionados em (SILVEIRA; NUNZIO, 2008, p. 6) como articuladores destas atividades estão: Alexandre Fenerich, Alfredo Votta, Bernardo Barros, Dantas Rampin, Valério Fiel da Costa, e, posteriormente, Gregory Slivar, Guilherme Rebecchi, Lucas Araújo e Rodrigo Felício.
} 
do primeiro ENCUN ${ }^{55}$. Após algumas atividades em parceria com outros colaboradores e coletivos, como a formação do grupo Marco04, e dos eventos Sarau 302 e P-Lugar ${ }^{56}$, Iwao e Del Nunzio optam por iniciar as atividades do Ibrasotope com base em algumas premissas relacionadas com suas experiências anteriores:

- A regularidade em termos de dia da semana, horário e local da realização de concertos, como forma de consolidar uma cena artística ao redor destes eventos;

- Chamadas públicas para a seleção de repertório destes eventos, favorecendo a execução de obras cujos criadores / compositores estejam presentes, com o objetivo de "estimular o debate, a circulação de informações e a sociabilização da crítica";

- Apropriações de espaços diversos para a prática musical, como é o caso da principal sala de concertos que "proporciona um ambiente intimista, amigável, confortável e com atenção concentrada no sonoro, sem necessidade de formalidades associadas aos ambientes de concerto tradicionais";

- Uma atenção à diversidade de abordagens "tanto na produção sonora[...], quanto nas diferentes posturas estéticas".

As atividades se dividem entre a organização de apresentações e oficinas na sede do Ibrasotope, a organização de eventos em locais diversos, como o Ciclo de Música Experimental e o Festival Internacional de Música Experimental (FIME), e também a produção e lançamento de registros fonográficos. A série principal de concertos teve início em 15 de dezembro de 2007 com o concerto [IBR01], que também inaugurou a sala de apresentações na sede do Ibrasotope, e em dezembro de 2016 chegou à edição [IBR108]. Uma das características da série [IBR] é ter dia da sema, local e horário fixo, buscando formar um "pólo aglutinador" que colabore para a estruturação de uma cena ${ }^{57}$. Além da série regular de apresentações, outras séries como a de concertos especiais - IBE, que em dezembro de 2016 chegou à edição [IBE58] - e a de concertos organizados pelo Ibrasotope em outros lugares - IBX, que em outubro de 2016 chegou à edição [IBX56] - também acontecem desde o início das atividades do núcleo ${ }^{58}$. Atualmente a coordenação e curadoria é feita por Mário Del Nunzio e Natacha Maurer. Além de abrigar as apresentações regulares e as oficinas, também serve de residência temporária para artistas, músicos e pesquisadores. Também sediou em 2008 o Primeiro Encontro Brasileiro de PureData, organizado por Alexandre Porres, e o Primeiro Encontro Brasileiro de Circuit Bending e Hardware Hacking.

55 Ver 2.2.6

56 (SILVEIRA; NUNZIO, 2008, p. 5-8)

57 (SILVEIRA; NUNZIO, 2008, p. 7)

58 Informações sobre datas e locais de eventos disponíveis em: <http://www.ibrasotope.com.br > e < https://ibrasotope.wordpress.com/dossie-ibrasotope-2007-2014/>. Acesso em 09 de janeiro de 2017. 


\subsubsection{Estúdio Fita Crepe SP}

Espaço localizado em São Paulo dedicado à realização "experimentação, criação e apresentação de trabalhos artísticos autorais nas áreas de som e movimento", que sedia regularmente oficinas e apresentações artísticas relacionadas com artes visuais, música experimental e pesquisa em corpo e teatralidade ${ }^{59}$. É coordenado por Kenia Dias e Ricardo Garcia, cuja parceria em estudos sobre movimento e sua relação com o som existe desde 2008. O espaço é uma extensão do trabalho de pesquisa de Garcia em sua busca por parcerias com artistas de outras linguagens, tendo transitado entre as cidades de São Paulo e Belo Horizonte entre os anos 2000 e $2011^{60}$. Sazonalmente o espaço sedia as atividades de um "Clube de Solda".

Os organizadores do espaço também foram responsáveis pela organização, entre os dias 18 e 26 de junho de 2016, do Festival Bigorna, que consistiu em um ciclo de debates, oficinas e apresentações musicais selecionadas a partir de convocatória ${ }^{61}$.

\subsubsection{Instituto Volusiano de Artes Avançadas}

Espaço dedicado à realização de oficinas com foco em linguagens de programação para as artes e creative coding. Sedia ocasionalmente eventos artísticos, e sua equipe organizadora também é responsável por eventos em outros locais ${ }^{62}$. O Instituto Volusiano de Artes surge a partir de uma demanda por "espaços de criação adequados no meio acadêmico e no meio das instituições de arte" ${ }^{" 63}$, buscando consolidar um espaço onde uma nova perspectiva para o ensino e compartilhamento de saberes relacionados com as artes e práticas criativas em geral.

O website <http://institutovolusiano.blogspot.com.br> cobre a oferta de cursos e os eventos organizados pelo Instituto no período entre 2012 e 2015. No período a partir de 2015, as ações do Instituto se desdobram nas iniciativas Rádio Volúsia ${ }^{64}$ e Volúsia Press ${ }^{65}$.

\subsubsection{Marcenaria do Ruben}

O marceneiro, luthier e artista uruguaio Ruben Pagani mantém uma marcenaria no bairro Vila Anglo, zona Oeste de São Paulo, onde trabalha regularmente com reforma e restauração de móveis e peças de madeira, e também realiza suas experimentações com

59 Disponível em: <http://www.estudiofitacrepesp.com>. Acesso em 24 de outubro de 2015.

60 Disponível em: <http://www.estudiofitacrepe.com.br/p/blog-page_4607.html>. Acesso em 11 de janeiro de 2017.

61 Disponível em: <http://www.festivalbigorna.com/2016/>. Acesso em 11 de janeiro de 2017.

62 Disponível em: <http://institutovolusiano.com.br>. Acesso em 24 de outubro de 2015.

63 Disponível em: < http://institutovolusiano.blogspot.com.br/p/blog-page_9.html>. Acesso em 27 de janeiro de 2017.

64 Disponível em: <https://www.facebook.com/radiovolusia/>. Acesso em 10 de janeiro de 2017.

65 Disponível em: <https://www.facebook.com/volusiapress/>. Acesso em 10 de janeiro de 2017. 
construção de instrumentos musicais, alguns dos quais se baseiam em modelos tradicionais - como cordofones que utilizam materiais alternativos para suas caixas de ressônancia - e outros que surgem a partir de experimentações com materiais específicos. O espaço acolhe cotidianamente artistas e pesquisadores interessados nas conexões entre luteria, experimentação sonora e artes visuais. A partir de 2016 o espaço passa a sediar oficinas de Luteria Experimental em parceria com Cadós Sanchez e o Brechó de Hostilidades Sonoras ${ }^{66}$, e também apresentações artísticas.

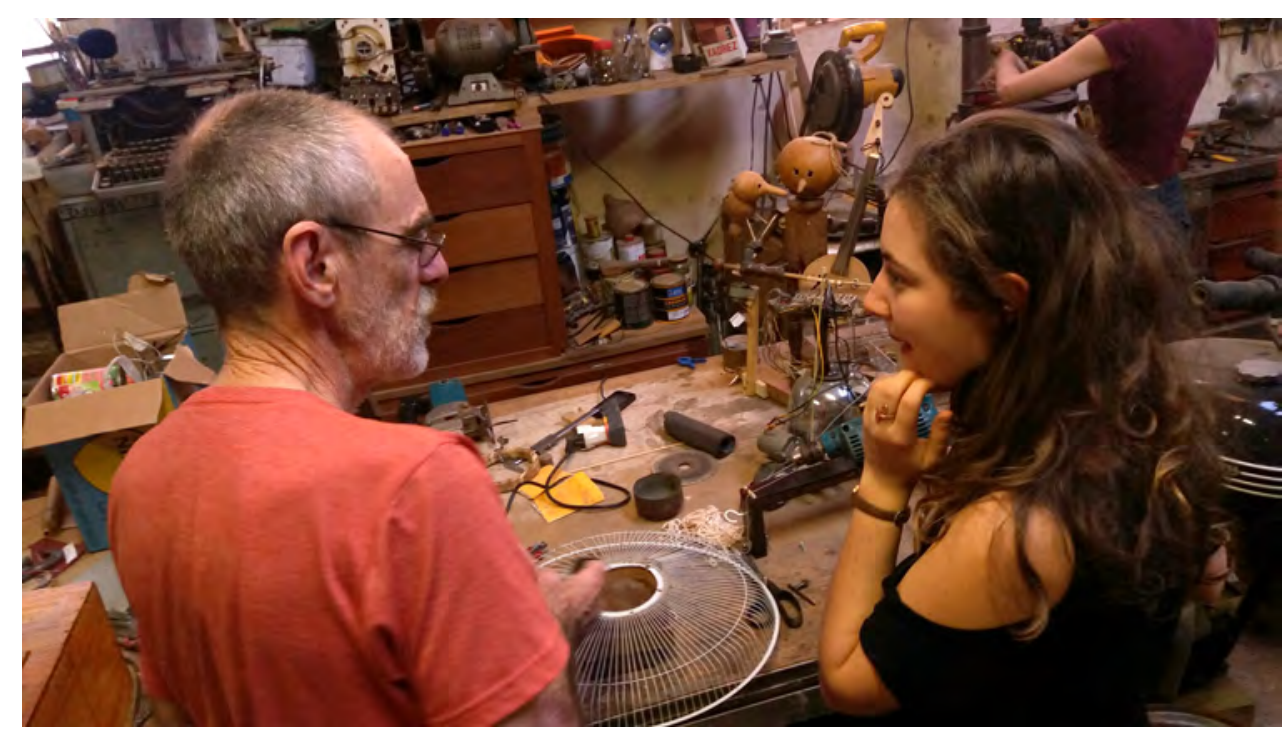

Figura 7 - Ruben Pagani e Mariana Carvalho em oficina na Marcenaria. Foto do autor.

Ao abrir sua marcenaria para a atividade de luteria experimental de outros artistas, assim como no momento das oficinas, Pagani transforma seu espaço de trabalho em uma espécie de metainstrumento, ou num grande instrumento coletivo e penetrável, cuja sonoridade é o resultado de atividades diferentes: a operação do maquinário se soma aos testes com instrumentos que estão sendo construídos, reconstruídos ou modificados; e a estes eventualmente se soma uma jam session informal que se desenvolve em paralelo às demais atividades. Um dia na marcenaria pode ser ouvido como uma grande peça sonora.

\subsubsection{Outros espaços}

Plano B O espaço Plano B existiu no Rio de Janeiro, na região da Lapa, entre 2004 e 2013, coordenado por Fernando Torres. O espaço funcionava como loja de discos e sediava regularmente apresentações de música experimental, de diversos estilos ${ }^{67}$.

Audio Rebel A Audio Rebel é uma casa de shows no bairro de Botafogo, no Rio de Janeiro, que também comporta estúdios de ensaio e compartilha o prédio com o

\footnotetext{
66 Disponível em:

<http://musicaemletras.blogfolha.uol.com.br/2016/09/09/ oifcina-na-marcenaria-do-ruben/> . Acesso em 16 de fevereiro de 2017.

67 Disponível em: < http://www.overmundo.com.br/guia/plano-b-lapa-1>. Acesso em 13 de janeiro de 2017.
} 
estúdio do produtor musical Alexandre Kassin. Sua programação abre espaço para eventos de música experimental mas também inclui artistas de outras cenas musicais independentes, mais próximos da música pop ou da música brasileira ${ }^{68}$.

Garoa Hacker Clube Hackerspace localizado no bairro de Pinheiros, em São Paulo, que sedia diversas atividades regulares contemplando oficinas e eventos para aprendizado e compartilhamento de saberes sobre linguagens de programação, prototipagem eletrônica, atividades artísticas e produção de cerveja ${ }^{69}$.

\subsubsection{ENCUN}

O Encun - Encontro Nacional de Criatividade Sonora - é organizado pela primeira vez na Unicamp em 2003 com o nome de "Encontro Nacional de Compositores Universitários", a partir de uma série de encontros realizados por alunos e professores de composição desta instituição ${ }^{70}$. Teve como comissão organizadora Anderson Severo, Clayton Mamedes, Gregory Slivar, Guilherme Rebecchi, Henrique Iwao, Lucas Araújo, Mário Del Nunzio e Valério Fiel da Costa $^{71}$. Um dos objetivos da criação do encontro é promover

a integração entre diferentes compositores de diversas regiões do país e com diferenciadas experiências na área; a aceitação da diversidade de manifestações musicais existentes; a resistência contra mecanismos autoritários e concentrações de poder,refletida em uma estrutura descentralizada, sem diretoria e comissões fixas ${ }^{72}$.

A realização do encontro é descentralizada e não conta com uma comissão permanente. A cada edição, comissões oriundas de diferentes lugares do país postulam a realização da próxima edição apresentando suas propostas para os participantes e organizadores da edição corrente ${ }^{73}$.

A partir da edição de 2016 o Encontro passa a se chamar "Encontro Nacional de Criatividade Sonora", mantendo a mesma sigla. A mudança busca refletir uma forma diferente de encarar os papéis envolvidos na produção musical experimental, abandonando a cisão entre as figuras de compositor, intérprete e público. Não houve uma edição em 2017, e até o presente momento a edição de 2018 não foi confirmada.

68 Disponível em: <http://audiorebel.com.br/>. Acesso em 10 de maio de 2018.

69 Disponível em: <https://garoa.net.br/wiki/Categoria:Eventos\{\#\}Eventos_regulares>. Acesso em 13 de janeiro de 2017

70 Ver 2.2.1

71 (SILVEIRA; NUNZIO, 2008, p. 6)

72 (SILVEIRA; NUNZIO, 2008, p. 6)

73 As edições do ENCUN ocorreram em Campinas - SP (2003 e 2015), Londrina - PR (2004), Curitiba PR (2005), Belém - PA (2006), São Paulo - SP (2007 e 2014), Salvador - BA (2008), Belo Horizonte - MG (2009), Goiânia - GO (2010), Porto Alegre - RS (2011 e 2016), Rio de Janeiro (2012), e João Pessoa - PB (2013). Para as datas e locais até 2014, (COSTA, 2013, p. 7), para demais informações: < https://www.facebook.com/encun.info/>. Acesso em 2 de fevereiro de 2017 


\subsubsection{Bloco Ruído}

O Bloco Ruído é uma iniciativa de André Damião que ocorre no centro de São Paulo, na quarta-feira de cinzas, desde 2015. No formato de um bloco de carnaval, reúnem-se músicos e interessados em música experimental que trazem aparelhos sonoros portáteis.

A ideia do bloco possui uma relação com a performance Avenida Paulista Eu Te Amo $\mathbf{n}^{\mathbf{0}} \mathbf{2}$, performance idealizada por Henrique Iwao para a quarta-feira de cinzas do carnaval de 2009 e que consistia do desfile do bloco Acadêmicos de Vila Nova Conceição na Avenida Paulista, repetindo o trajeto de outra performance - "Avenida Paulista Eu Te Amo no1"74 - feita por Iwao e Pan\&Tone em 2008. O nome do suposto bloco "Acadêmicos de Vila Nova Conceição" faz referência ao bairro onde se localiza o Ibrasotope. Além de Iwao e Pan\&Tone participaram de "Avenida Paulista Eu Te Amo No. 2" Pedro Galvão e André Bandeira.

A ideia de fazer a performance na quarta-feira de cinzas no período da tarde ou da noite é proposital, para que o bloco, assim como a performance, interaja com a população urbana nesse momento de transição entre o período de carnaval e o retorno às atividades regulares.

\subsubsection{Panorama da Luteria Experimental}

No mês de outubro de 2016 foi realizado em São Paulo o "I Panorama da Luteria Experimental". Os artistas participantes possuem abordagens distintas em relação à construção de instrumentos, assim como em relação à criação sonora e musical:

- André Damião;

- Fernando Sardo e Loop B;

- Adriano Castelo Branco;

- Barulho Max e Ritamaria;

- Rodrigo Olivério;

- Thiago Salas;

- Ruben Pagani;

- Brechó de Hostilidades Sonoras;

- Cadós Sanchez;

${ }_{74}$ Disponível em: <http://henriqueiwao.seminalrecords.org/avenida-paulista-eu-te-amo-no-1/>. Acesso em 14 de março de 2017. 
O festival se dividiu entre a Praça das Artes, que recebeu apresentações dos participantes, e a Passagem Literária da Consolação, onde também ocorreram apresentações assim como a exposição permanente de diversos instrumentos.

\subsubsection{Outros eventos}

FIME O Festival Internacional de Música Experimental - é um evento realizado em São Paulo anualmente desde 2015 por Mário del Nunzio e Natacha Maurer, também responsáveis pela organização e curadoria do Ibrasotope. O repertório é organizado de forma mista, a partir de convites da curadoria e também de chamada pública para peças e propostas de oficina ${ }^{75}$.

Festival Música Estranha O Festival Música Estranha acontece na cidade de São Paulo desde 2013, em diferentes espaços. Seu principal organizador e curador é o compositor e produtor Thiago Cury, sócio da empresa ÁGUAFORTE ${ }^{76}$, responsável pela organização do evento. Ao longo de 4 edições o festival realiza concertos, oficinas e debates com foco no repertório e na produção de música experimental contemporânea $^{77}$.

RUMOR Série de apresentações mensais, organizadas em Recife - PE por Cássio Sales e Yuri Bruscky, desde 2015, a partir de 2017 passa a contar também com ciclos de palestras e oficinas. Os eventos se propõem a ser uma "instância de fomento às práticas sonoras experimentais em Pernambuco e ao diálogo criativo entre a música e outras linguagens artísticas"78, e possui relação com outras iniciativas organizadas na região como o programa de seminários e residências Entre lugares sonoros ${ }^{79}$.

Ciclo de Música Experiental Série de concertos que ocorreu mensalmente entre Julho e Dezembro de 2016, em uma sala de espetáculos na Biblioteca Mário de Andrade, localizada na Rua da Consolação, 94, no centro de São Paulo. A organização e curadoria da série é feita pelos responsáveis do Ibrasotope, e busca contemplar diferentes tendências criativas dentro do cenário atual de música experimental ${ }^{80}$.

\footnotetext{
$\overline{75}$ Disponível em:<https://www.facebook.com/fime.art/>. Acesso em 10 de maio de 2018

76 Disponível em: <http://www.aguaforte.org > Acesso em 2 de fevereiro de 2017

77 Disponível em: <http://www.musicaestranha.me>. Acesso em 1 de fevereiro de 2017

78 Disponível em: < https://www.facebook.com/pg/rumorexp/about/?ref=page_internal>. Acesso em 28 de dezembro de 2016.

79 Disponível em: <https://www.facebook.com/entrelugaressonoros/>. Acesso em 10 de maio de 2018.

80 Disponível em: <https://www.facebook.com/pg/ciclodemusicaexperimental/about/?ref=page_ internal>. Acesso em 21 de dezembro de 2016.
} 


\subsection{Personagens}

Como mencionado anteriormente, nesta seção dou ênfase ao trabalho de alguns artistas - individualmente, em duos ou grupos - encontrados a partir de um levantamento feito para esta pesquisa, mas que tem como ponto de partida outras iniciativas anteriores. Relaciono aqui os artistas cujo trabalho consegui pesquisar mais extensamente, e incluí uma seção em C para citar demais nomes.

\subsubsection{Tato Taborda}

Tato Taborda é o nome artístico de Pretextato Taborda Junior, nascido em Curitiba a 11 de janeiro de $1960{ }^{81}$. Possui formação musical tradicional e acadêmica com Doutorado em Música pela UNIRIO, e sua produção como compositor é bastante vasta, incluindo obras para instituições e corpos musicais estabelecidos ${ }^{82}$. Como construtor de instrumentos, destaca-se por ter criado e realizado diversas modificações em um único instrumento, a Geralda, ao longo de mais de duas décadas.

\section{Projetos}

Geralda A Geralda surge na primeira metade dos anos 1990. Algumas fontes sugerem o ano de 1992, com o instrumento surgindo a partir de uma pesquisa financiada pela Fundação Vitae, construído em parceria com Alexandre Boratto ${ }^{83}$. O projeto originalmente previa a construção do instrumento e a composição das obras "Canções de Musgo" e "Pó", inspiradas na obra de Manoel de Barros ${ }^{84}$. Sua estrutura inspira-se na figura do homem-banda ${ }^{85}$ - papel tradicionalmente desempenhado por músicos de rua ou por artistas de circo - com uma abordagem estética e técnica que aproxima aquela figura tradicional da prática de música experimental.

O nome Geralda é dado em 2002 por uma amiga pessoal de Tato. Segundo o mesmo, a descoberta de que a Geralda é uma entidade feminina modifica sua abordagem ao executar o instrumento ${ }^{86}$. Em sua versão atual, a Geralda está equipada com 70 fontes sonoras diferentes, todas amplificadas e passíveis de processamento em um gerador de loops criado por Matthias Grob ${ }^{87}$. Também

81 Disponível em <https://pt.wikipedia.org/wiki/Tato_Taborda>, Acesso em 20 de agosto de 2016.

82 Disponível em: <http://lattes.cnpq.br/5444189855425611>. Acesso em 08 de dezembro de 2016

83 Disponível em: <http://www.matthiasgrob.org/TatoTabordaP.htm>. Acesso em 08 de dezembro de 2016

84 Disponível em: <https://youtu.be/EHPxQPDzXZg>. Acesso em 08 de dezembro de 2016

85 Disponível em: < http://www.matthiasgrob.org/TatoTabordaP.htm>. Acesso em 08 de dezembro de 2016

86 Disponível em: <http://www.matthiasgrob.org/pPictures/geralda.htm>. Acesso em 08 de dezembro de 2016

87 Disponível em: < http://www.matthiasgrob.org/pPictures/geralda.htm>. Acesso em 08 de dezembro de 2016 
possui seu próprio sistema de amplificação e difusão sonora.

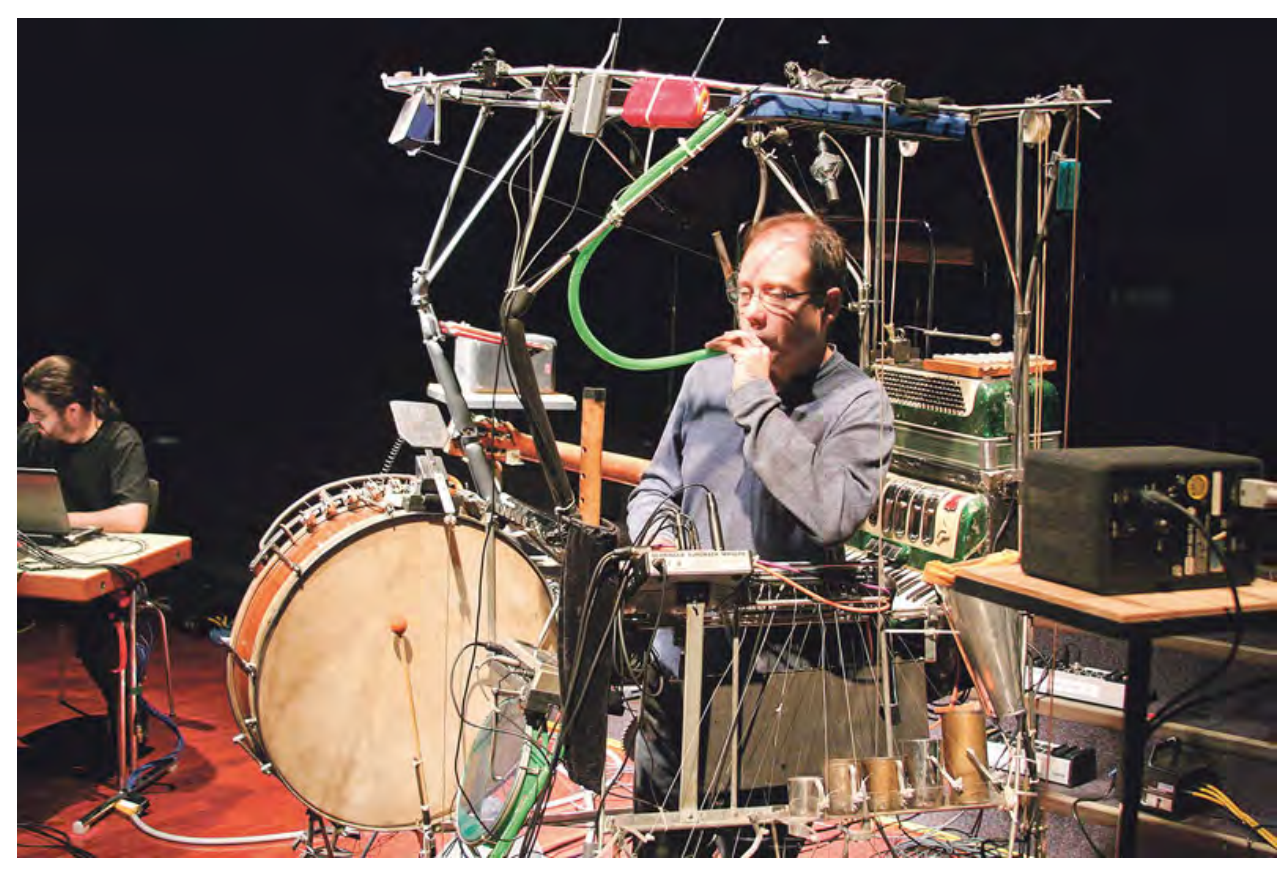

Figura 8 - Tato Taborda em performance com a Geralda, ao fundo vê-se Alexandre Fenerich. Foto: Tato Taborda.

Felisberto Felisberto é um processo de preparação e modificação de pianos para performances, que consiste na inserção de sensores nas cordas correspondentes a algumas das notas mi. Os sensores inseridos ativam pequenos rádios modificados. Além dos sensores, Taborda também realiza uma preparação do piano no sentido convencional. Assim como ocorre na Geralda, o Felisberto também possui um complemento virtual tocado por Alexandre Fenerich, como pode ser visto neste vídeo: <https://www.youtube.com/watch?v=sgQA8B2RQho $>^{88}$.

\subsubsection{Wilson Sukorski}

Nascido em São Paulo em 1955, Wilson Roberto Sukorski define-se como "compositor, músico eletrônico, performer multimídia, criador/produtor de conteúdos musicais para rádio/vídeo/cinema, designer e construtor de instrumentos musicais inusitados e pesquisador em áudio digital" 89 . Foi aluno de composição e regência da UNESP e sua atuação nas últimas décadas tem focado na composição para cinema, audiovisual, e na criação de instalações sonoras e ambientes multimeios. No tocante à construção de instrumentos, Sukorski estudou um período com Smetak ${ }^{90}$, cuja influência é percebida nos instrumentos

\footnotetext{
88 Acesso em 15 de junho de 2016

89 Disponível em: <http://www.sukorski.com/pdp2014.html>. Acesso em 5 de junho de 2017.

90 (PAOLI, 2011, p. 182), (SCARASSATI, 2015, p. 165).
} 
Roda Pequena, Roda Grande e Peixe ${ }^{91}$, entre outros, e cujo design é compartilhado com Márcio Valadão e José Wagner Garcia ${ }^{92}$.

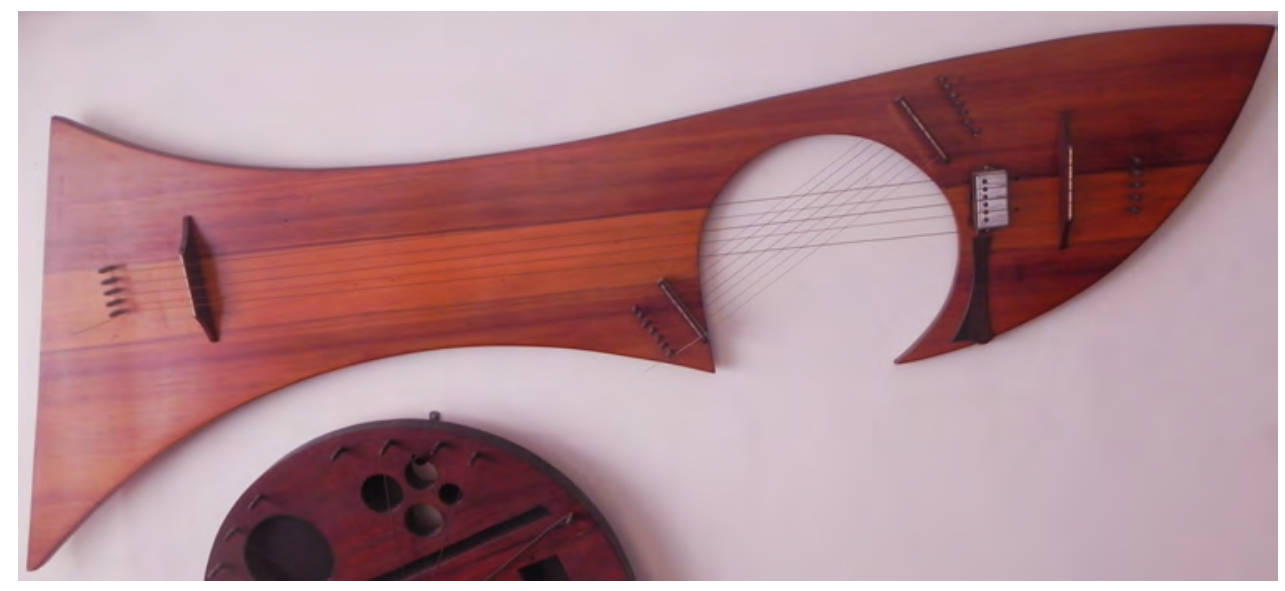

Figura 9 - Peixe, de Wilson Sukorski e José Wagner Garcia. Foto: Wilson Sukorski.

Juntamente com Lívio Tragtenberg, Sukorski desenvolve a partir dos anos 1990 o projeto DeMolições Musicais, no qual incluem pessoas em situação de rua e pessoas com deficiências físicas e mentais como intérpretes, fazendo uso de um instrumental composto por utensílios domésticos, readymades sonoros mecânicos e eletroeletrônicos ${ }^{93}$. Em Scarassatti (2015, p. 164-166) Sukorski afirma que ultimamente está mais envolvido com a criação de instrumentos em ambientes virtuais como Csound, Max/MSP e SuperCollider.

\subsubsection{Chico Machado}

Chico Machado é o nome artístico de João Carlos Machado, artista plástico, músico e professor universitário, nascido em 22 de agosto de 1964 em Santo Ângelo, Rio Grande do $\mathrm{Sul}^{94}$. Atuante no circuito de artes plásticas, teatro e publicações independentes do Rio Grande do Sul desde os anos 1980, possui formação acadêmica em nível de Graduação e Pós-graduação em Artes Visuais na UFRGS ${ }^{95}$ e também integrou a banda Aristhóteles de Ananias Jr. como baixista e compositor, tendo desenvolvido ao longo dos anos parcerias musicais com outros artistas da cena musical underground de Porto Alegre e do Rio Grande do Sul.

Sua produção nas artes plásticas funciona como para estimular um espaço de encontro entre seus diferentes campos de atuação, sendo a dimensão sonora um elemento importante do seu trabalho, assim como a interação física do público ou do artista com

91 Disponível em: <http://www.sukorski.com/Instrumentos/index.html>. Acesso em 15 de junho de 2016

92 (SCARASSATI, 2015, p. 165)

93 (OBICI, 2014, p. 122-123)

94 Disponível em: < https://pt.wikipedia.org/wiki/Chico_Machado>. Acesso em 18 de fevereiro de 2018.

95 Disponível em: <http://lattes.cnpq.br/8905381444844460>. Acesso em 15 de março de 2017. 
algumas de suas obras. Na criação de suas obras, Chico Machado realiza uma integração com tecnologias diferentes de diversos níveis de complexidade, utilizando-se de motores elétricos, circuitos eletrônicos, projeções e também de engrenagens e maquinarias simples para gerar som e movimento.

\section{Projetos}

Ritimifiqueitor Instrumento cinético em que o executante empurra uma alavanca em cuja ponta está acoplada uma roda de madeira de aproximadamente um metro de diâmetro. Ao girar em um grande círculo, a roda produz sons a partir de objetos dispostos previamente no seu percurso, criando um loop de eventos sonoros. Segundo o artista, o ritimifiqueitor é um "ritmificador, um sistema de relação entre objetos, desenvolvido para que possamos obter ritmos sonoros a partir de um movimento de passagem de uma roda sobre obstáculos colocados ao longo de um circuito circular ou elíptico" ${ }^{96}$. Chico Machado também desenvolveu o projeto de um ritimifiqueitor caseiro, que pode ser montado e executado por qualquer pessoa, a partir das instruções contidas em um manual publicado online: < https://ritimifiqueitor.files.wordpress.com/ 2011/09/manualdoritimifiqueitorcaseiro.pdf $>{ }^{97}$.

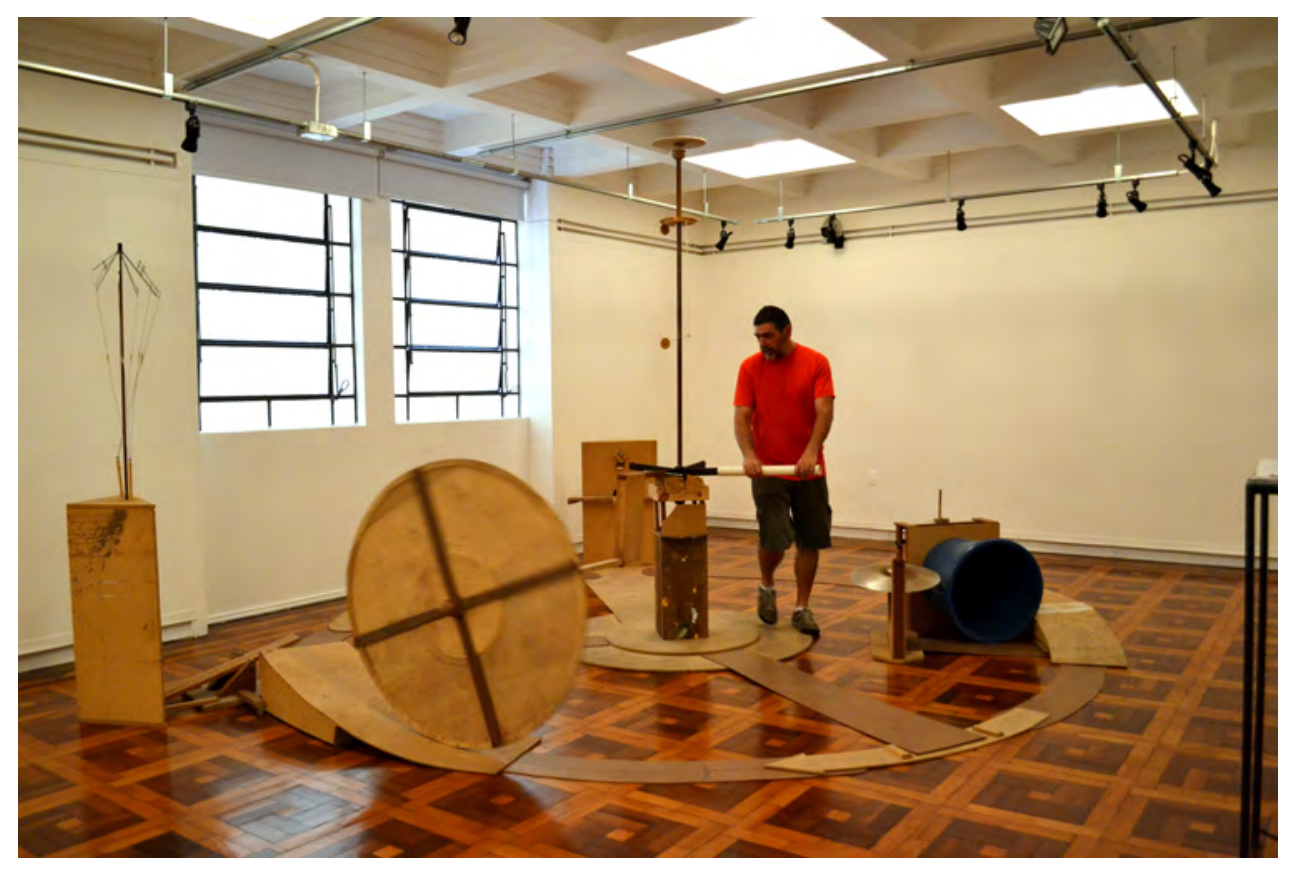

Figura 10 - Chico Machado e o Ritimifiqueitor. Foto: Chico Machado.

Aparelhos sonoros diversos Aparelhos sonoros independentes, normalmente baseados em um único princípio de geração sonora, para serem acionados pelo

96 (MACHADO, 2011, p. 4).

97 Acesso em 19 de Novembro de 2017 
público. A produção destes aparelhos sonoros pelo artista em termos já abrange algumas décadas, tendo início em meados dos anos 1990.

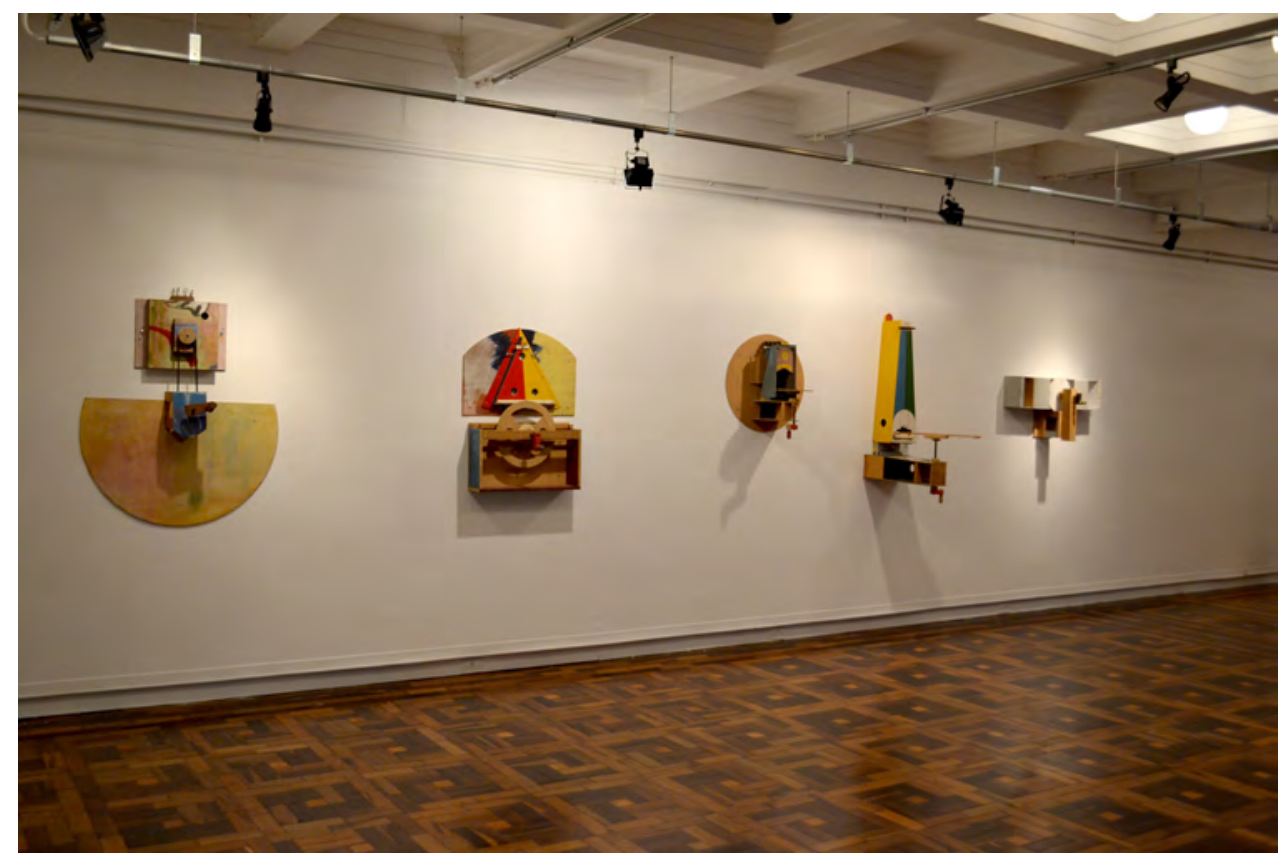

Figura 11 - Aparelhos sonoros de Chico Machado em exposição. Foto: Chico Machado.

Página da internet $<$ https://chicomachado.wordpress.com/ $>$ e $<$ https://ritimifiqueitor. wordpress.com/>

\subsubsection{Loop B}

Loop B é o nome artístico de Lourenço Prado Brasil, nascido em São Paulo em 13 de Agosto de 1954, músico que criou um repertório de instrumentos a partir de sucata e objetos encontrados. Sua carreira como percussionista tem início nos anos 1970 sob a influência da música de Hermeto Paschoal e do rock progressivo, e a partir dos anos 1980 tem contato com a música eletroacústica europeia e forma o grupo de música experimental Lendas. Em 1985 forma junto com Anjo Flores, Téo Ponciano e Márcia Nunes o grupo de "pós-industrial primitivo" Kumbai Nidada"8 Einstürzende Neubauten ${ }^{99}$ e em cuja música a percussão em sucata se torna um elemento mais presente ${ }^{100}$.

Nos anos 1990, a partir da dissolução do grupo, ficou conhecido na cena independente de música no Brasil por produzir música associada ao gênero industrial, mesclando seus instrumentos com programações de batidas e arranjos eletrônicos. Em seu trabalho a

98 (MARKE, 2017, p. 69).

99 Disponível em: <http://www1.folha.uol.com.br/fsp/ilustrad/fq1409200020.htm>. Acesso em 13 de Fevereiro de 2018.

${ }^{100}$ Disponível em: <https://www.youtube.com/watch?v=R4Wu5-f1Tq8>. Acesso em 13 de fevereiro de 2018. 
característica predominante é a de reaproveitamento e ressignificação de objetos achados, na forma de readymades sonoros, observando-se pouca ou nenhuma modificação destes no tocante à preparação para performances ${ }^{101}$ : "Eu não construo instrumentos, eu gosto de pegar uma coisa do jeito que ela tá e aí como é que eu consigo tirar som disso aqui?"102. Também atua como facilitador de oficinas sobre percussão em sucata e música eletrônica.

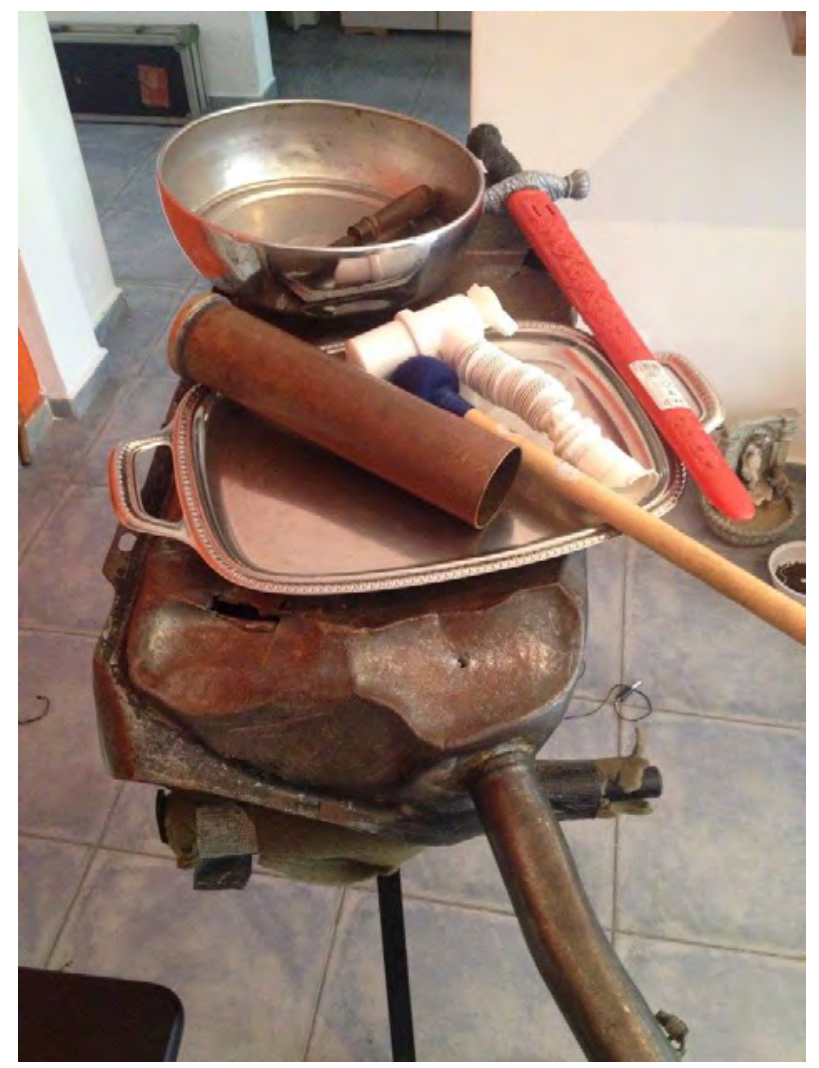

Figura 12 - Objetos utilizados por Loop B em suas performances. Foto: Loop B.

Diversos fatores influenciam na escolha dos objetos para performance, desde o potencial cênico do objeto até suas dimensões:

Quando encontro algo eu fico tocando, tocando e tocando, explorando de várias formas o objeto [...] Isso passa também por aspectos concretos: espaço no palco, tempo de montagem e passagem de som, se vou de carro ou de avião, são muitos fatores determinantes.

Atualmente Loop B tem desenvolvido parcerias também com outros artistas que constroem instrumentos, como Fernando Sardo, e acompanhado a produção de alguns outros artistas, como Adriano Castelo Branco, observando que no cenário de luteria

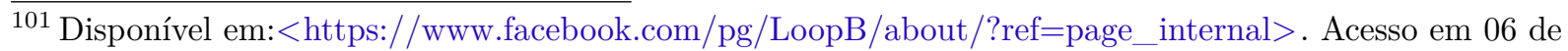
dezembro de 2017.

102 Depoimento de Loop B para o Rumos Itaú Cultural Música, disponível em: <https://www.youtube. com/watch?v=R4Wu5-f1Tq8>. Acesso em 18 de fevereiro de 2018.
} 
experimental atual há uma "iconoclastia inerente" às pessoas envolvidas com a construção de instrumentos experimentais.

Página da internet <https://www.facebook.com/LoopB $>$

\subsubsection{Fernando Sardo}

Fernando Sardo, nascido em 20 de agosto de $1963^{103}$, é músico multi-instrumentista, artista plástico e arte-educador, em atuação desde 1980. Também ministra oficinas sobre música e luteria desde 1989, com ênfase no potencial de inclusão social deste tipo de aprendizado $^{104}$.

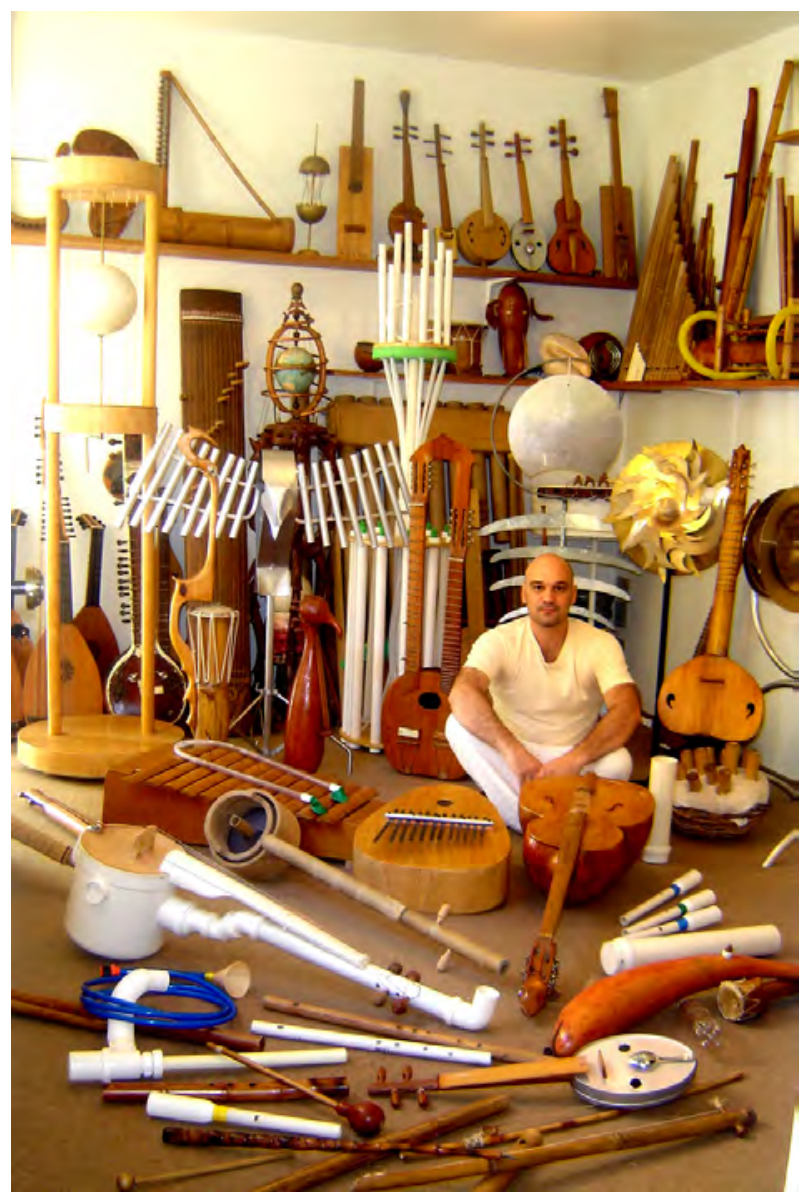

Figura 13 - Fernando Sardo em sua oficina. Foto: Divulgação.

Sua produção como construtor de instrumentos inclui tanto instrumentos tradicionais - construídos como parte de uma pesquisa sobre instrumentos de diversas origens - quanto instrumentos inéditos criados a partir deste mesmo trabalho de pesquisa, e já conta com mais de 100 instrumentos construídos. Além de construir instrumentos para

\footnotetext{
${ }^{103}$ Disponível em: < http://enciclopedia.itaucultural.org.br/pessoa103266/fernando-sardo>. Acesso em 13 de fevereiro de 2018.

${ }^{104}$ Disponível em: <http://www.fernandosardo.com.br/portugues/>. Acesso em 13 de fevereiro de 2018.
} 
performance musical, também cria esculturas sonoras de diversas escalas, incluindo-se aí projetos para espaços públicos e iniciativas educacionais, e atua como compositor de trilhas sonoras para diversos meios. Na criação de seus instrumentos, trabalha com uma grande variedade de materiais, de modo semelhante ao que pode ser observado na produção de Smetak e de Marco Antônio Guimarães no tocante ao uso de cabaças, tubos de PVC, conduíte e materiais reaproveitados, como no caso do Sol, instrumento feito a partir de pratos de bateria reaproveitados. Obici (2014, p. 114) também reconhece no trabalho de Sardo ressonâncias da obra de Smetak. Participou do primeiro Panorama da Luteria Experimental apresentando-se em duo com Loop B.

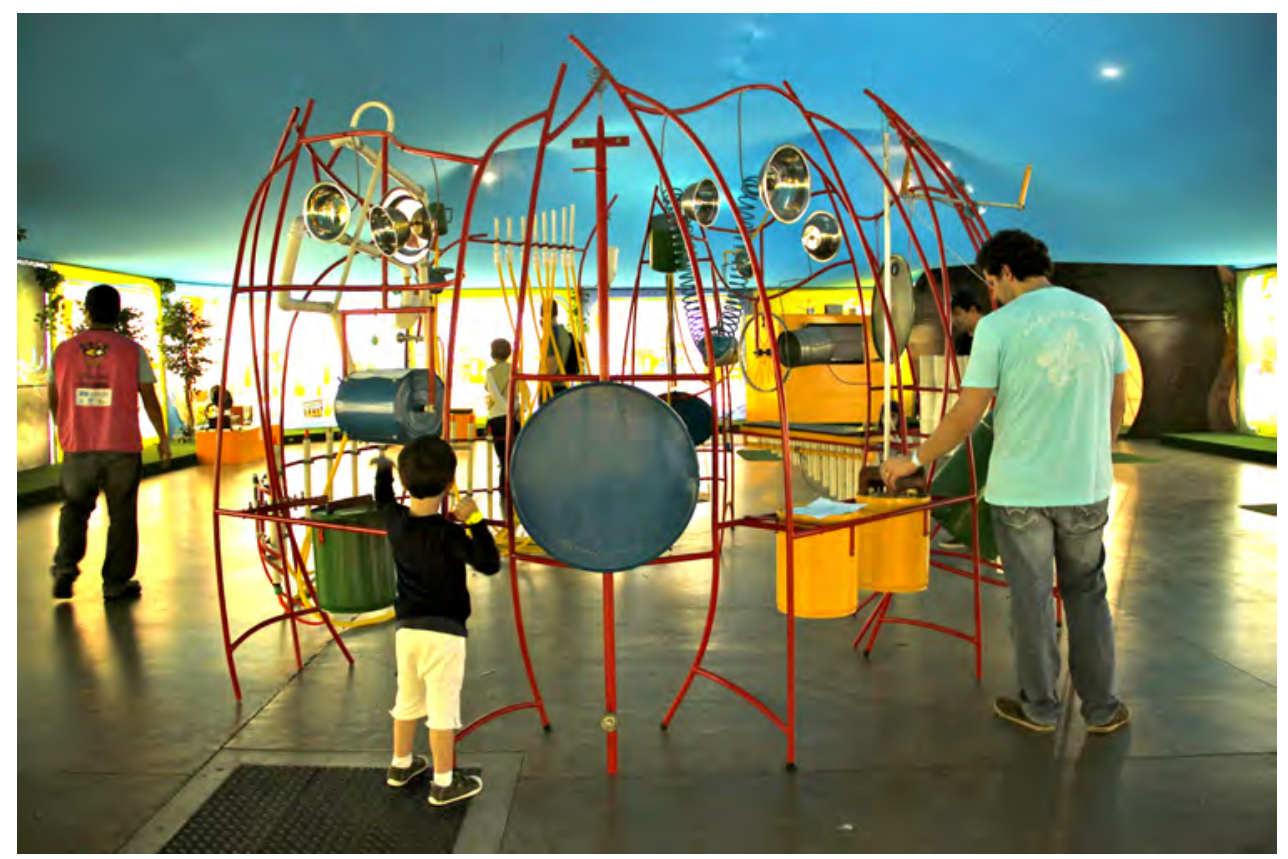

Figura 14 - Instalação sonora Sons Recicláveis, criada por Fernando Sardo para a Sabina Escola Parque do Conhecimento, espaço cultural da Prefeitura de Santo André, SP. Foto: Maria Juliana Moura.

Sardo também é fundador do GEM, Grupo Experimental de Música, coletivo que trabalha com luteria experimental voltada para a confecção de instrumentos em sua maioria acústicos, em integração com artes visuais e performance. O grupo foi fundado em 2003 em Santo André - SP por Sardo, Fábio Marques, Luciano Sallun, Rodrigo Olivério, Bira Azevedo e Flávio Cruz. A formação atual do grupo é composta pelas mesmas pessoas, com exceção de Bira Azevedo e Flávio Cruz, e conta com Fábio Daros e Rodrigo Rossi. O grupo tem como proposta "realizar apresentações musicais e oficinas incentivando a criatividade e a utilização de materiais recicláveis como recurso para vivenciar a música"105. Boa parte do trabalho do grupo tem relação com o reaproveitamento de materiais do cotidiano, utilizados na criação de instrumentos coletivos como o Dessintetizador, tocados por

\footnotetext{
$\overline{105}$ Disponível em: <https://www.facebook.com/pg/grupoexperimentaldemusica/about/?ref=page_
} internal> 


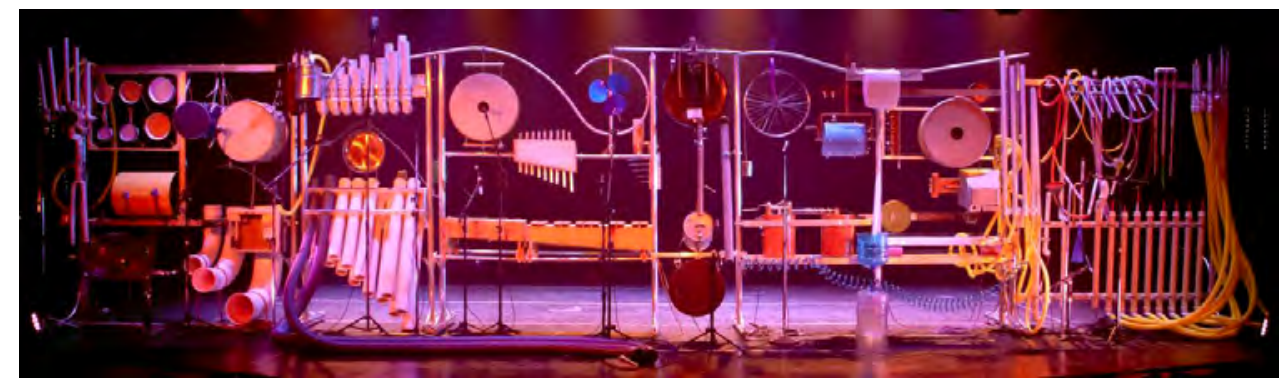

Figura 15 - Dessintetizador, instrumento coletivo do Grupo Experimental de Música. Foto: Divulgação.

diversos membros do grupo simultaneamente no caso de apresentações que seguem um formato tradicional com divisão entre palco e platéia, mas que também funcionam como instalações sonoras que podem ser tocadas e manipuladas pelo público em geral em eventos em que o público tenha acesso direto à instalação. Além do trabalho feito neste formato, o Grupo também se apresenta tocando instrumentos individuais, de acordo com o formato do evento. A atuação do grupo desde sua fundação compreende trabalhos autônomos, mas também parcerias com outros artistas como o grupo de dança de Ivaldo Bertazzo, o grupo MOS e a Companhia de Danças de Diadema, participações na trilha sonora de filmes independentes e apresentações junto a outros músicos, como o pernambucano Naná Vasconcelos.

Página da internet < http://www.fernandosardo.com.br/>

\subsubsection{Marco Scarassatti}

Marco Scarassatti, nascido em Campinas em 1971, é professor universitário, pesquisador, compositor e construtor de instrumentos e esculturas sonoras. Desenvolveu uma pesquisa sobre a obra de Walter Smetak em nível de Mestrado a partir da qual escreveu o livro Walter Smetak: O Alquimista dos Sons (2008). Tendo iniciado seus estudos musicais como saxofonista, fez graduação em composição na UNICAMP, e o contato com a obra de Smetak pode ser entendida como uma influência importante em seu processo criativo:

O contato com a obra e o pensamento do Smetak provocou uma espécie de epifania e ficou muito claro que o caminho de busca pela música que eu queria fazer, passava por construir meus próprios dispositivos de se fazer música ${ }^{106}$.

\footnotetext{
$\overline{106}$ Scarassatti em entrevista para o portal "O Cafezinho". Disponível em: < https://www.ocafezinho.com/ 2016/08/03/rumores-do-cotidiano-entrevista-com-o-artista-sonoro-marco-scarassatti/>. Acesso em 23 de fevereiro de 2018.
} 
Em seu trabalho de criação busca lidar com a questão do espaço sonoro, e sua produção de instrumentos está relacionada com dois conceitos, o conceito de emblema sonoro e o conceito de dispositivo. O conceito de emblema sonoro possui relação com a ideia de plástica sonora em Smetak, diferindo no sentido em que o emblema sonoro é um objeto que pode ser ativado para produzir sons, e é definido como uma "uma forma complexa, composta por um aglutinado de pequenos símbolos que se desdobram em potência latente para uma sonoridade resultante"107. Já a ideia de dispositivo tem como base o conceito de dispositivo / contradispositivo de acordo com Agamben ${ }^{108}$. A criação destes dispositivos se baseia em um "modus operandi bricoleur", através do qual promove continuamente um processo de construção, desconstrução e reconstrução de seus instrumentos: "É um exercício de desapego, porque os instrumentos passam a ser formas transitórias de processos composicionais"109. Este processo não é definido por Scarassatti como uma luteria, estando mais próximo de uma antiluteria que busca compor uma estrutura sistêmica que atuará sobre quem toca um determinado dispositivo ${ }^{110}$.

Também é membro do grupo Sonax, fundado em 2003 juntamente com Marcelo Bomfim e que desde 2005 conta também com Nelson Pinton. O grupo estrutura seu processo de performance e composição a partir do improviso coletivo envolvendo as criações de Scarassatti.

\section{Projetos}

Tzim Tzum O nome Tzim Tzum faz referência a um mito de criação da Cabala, e o instrumento foi feito em 2005 a partir da reutilização de peças de um instrumento anterior, Vórtice, que por sua vez se originou de uma escultura sonora criada em 2002. Consiste em duas rodas de metal, concêntricas, apoiadas sobre uma caixa de isopor na qual também estão atravessados vergalhões de metal utilizados em construção. O instrumento pode ser percutido, mas também produz sons a partir do giro das rodas ${ }^{111}$. Vide Figura 16.

\footnotetext{
107 Scarassatti em entrevista ao portal interact. Disponível em: < http://interact.com.pt/22/ tres-artesaos-entrevista/>. Acesso em 20 de fevereiro de 2018.

${ }^{108} \mathrm{O}$ conceito de dispositivo em Agamben (2009, p. 40), por sua vez, é inspirado no conceito de dispositivo utilizado por Foucault, e é formulado da seguinte maneira:

Chamarei literalmente de dispositivo qualquer coisa que tenha de algum modo a capacidade de capturar, orientar, determinar, interceptar, modelar, controlar e assegurar os gestos, condutas, as opiniões e os discursos dos seres viventes.
}

Abaixo, no item 2.4, retomo o conceito de dispositivo aplicado a instrumentos musicais proposto por Scarassatti

${ }^{109}$ Scarassatti em entrevista para o portal "O Cafezinho". Disponível em: < https://www.ocafezinho.com/ 2016/08/03/rumores-do-cotidiano-entrevista-com-o-artista-sonoro-marco-scarassatti/>. Acesso em 23 de fevereiro de 2018.

110 Scarassatti em depoimento à revista Oro Molido, disponível em: < http://www.oromolido.com/2016/ 03/oro-molido-42-edicion-pdf.html $>$. Acesso em 22 de fevereiro de 2018.

${ }^{111}$ Descrição do instrumento por Scarassatti em < http://interact.com.pt/22/tres-artesaos-entrevista/> . Acesso em 22 de fevereiro de 2018. 


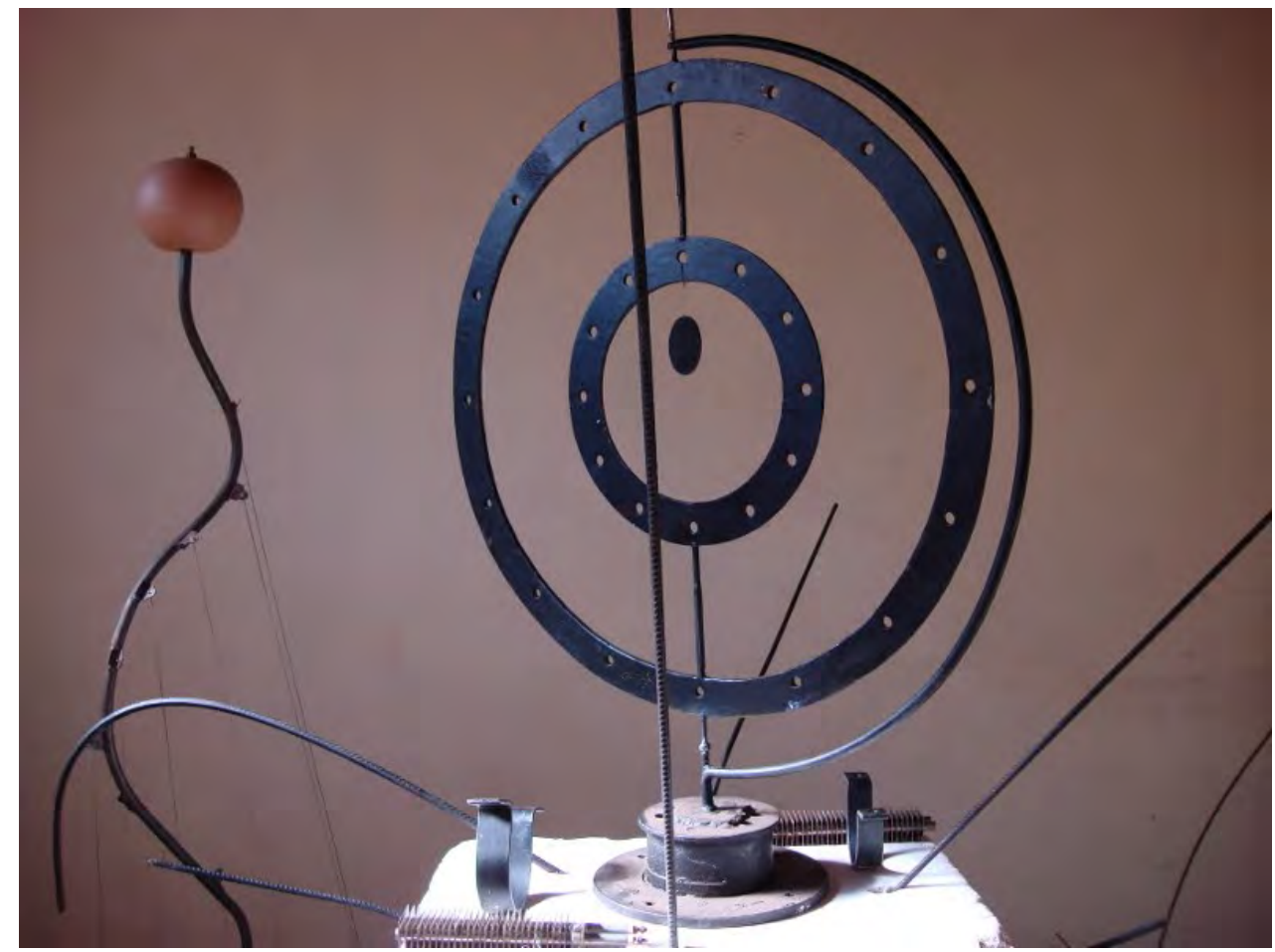

Figura 16 - Tzim Tzum de Marco Scarassatti. Foto: Alan Victor Pimenta.

Capacetes para deriva sonora Os capacetes são instrumentos de escuta, nos quais o usuário escuta os sons ao seu redor filtrados por meio de diferentes tipos de materiais que atuam como filtros físicos de som. São utilizados para derivas sonoras individuais ou coletivas. Vide Figura 17.

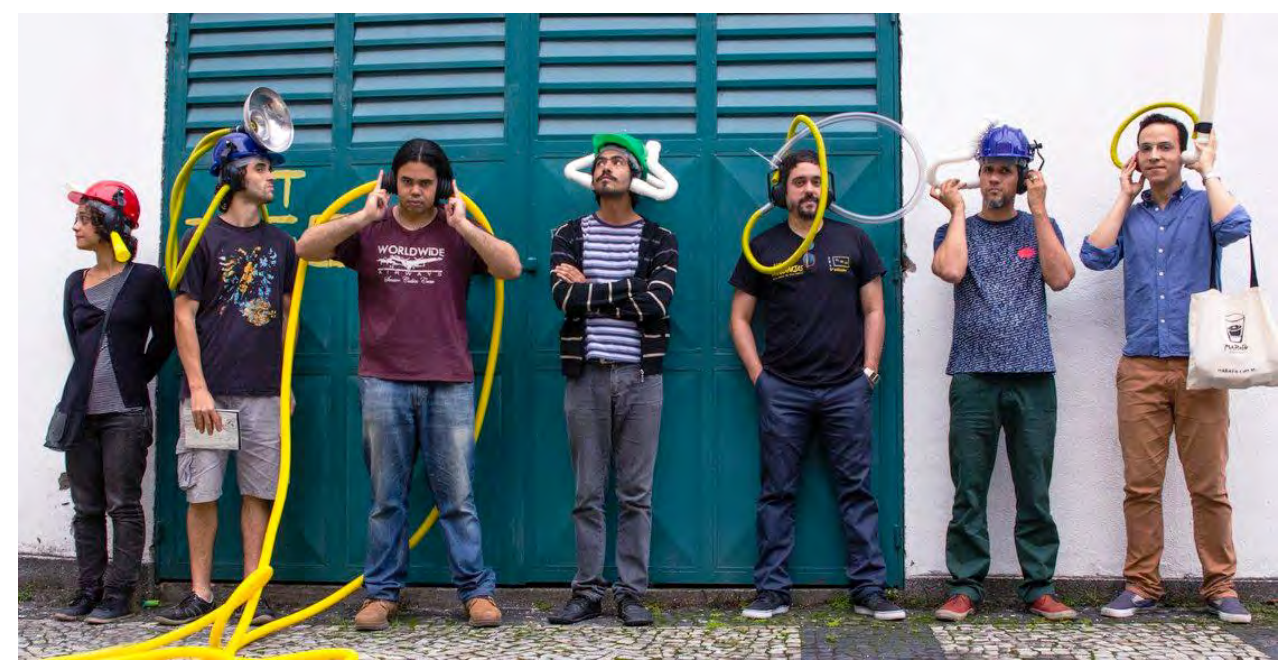

Figura 17 - Capacetes para deriva sonora de Marco Scarassatti, utilizados no festival Novas Frequências. Foto: Divulgação.

Página da internet < https://soundcloud.com/marco_scarassatti> 


\subsubsection{Eduardo Néspoli}

Compositor e construtor de instrumentos, também professor da Universidade Federal de São Carlos, constrói instrumentos eletromecânicos, eletrônicos e digitais, sendo comum a integração de instrumentos de naturezas diferentes no processo performático e composicional. Néspoli trabalha com a ideia de gambiarra como um método de adaptar e reaproveitar partes diversas, tanto no nível material físico quanto no nível de programação, para viabilizar sua prática musical. Alguns de seus projetos envolvem a reutilização de aparelhos eletroeletrônicos descartados, estando estes ainda funcionais ou não, e a combinação destas partes é um processo de constante recriação:

"As escolhas não são fáceis de serem realizadas, pois, como utilizo processamento digital via software, é preciso combinar fonte sonora e programação, o que deixa sempre o sistema instável e com muitas variações. Na medida em que estas relações se ajustam, o conjunto instrumental é circunscrito. A fixação ocorre, eu diria, momentaneamente para uma apresentação, pois há casos em que, para uma mesma peça, eu alterei o instrumental ou os parâmetros de processamento"112.

Néspoli também articula seu trabalho de construção de instrumentos integrando hardware e software com projetos e publicações voltadas para a educação musical ${ }^{113}$.

Projetos RevistaHertz Instalação audiovisual que combina imagens coletadas em publicações de grande circulação ao longo dos anos 1960, 1970 e 1980, amostras sonoras de discursos históricos e também estações de rádio acessadas em tempo real. Uma interface é disponibilizada para o público para que os participantes possam compor o material audiovisual em tempo real ao visitarem a instalação ${ }^{114}$. Vide Figura 18

Página da internet <https://eduardonespoli.wordpress.com/>, <https://revistahertz. wordpress.com/>

\subsubsection{Pan\&Tone}

Pan\&Tone é nome artístico de Cristiano Rosa, artista sonoro e visual gaúcho que "trabalha para transformar técnicas convencionais em laboratórios poéticos"115, com uma ênfase grande nas práticas de alteração de circuitos. Sua produção com música experimental tem início em 1989, com performances envolvendo colagens de fitas cassete, uso de efeitos de microfonia e feedback e também percussão em sucata, tendo iniciado suas

\footnotetext{
$\overline{112}$ Néspoli apud (SCARASSATI, 2015, p. 175).

113 (NÉSPOLI, 2017).

${ }^{114}$ Disponível em: <https://revistahertz.wordpress.com/>. Acesso em 26 de fevereiro de 2018.

${ }^{115}$ Disponível em: <http://panetone.net/about/>. Acesso em 01 de outubro de 2013.
} 


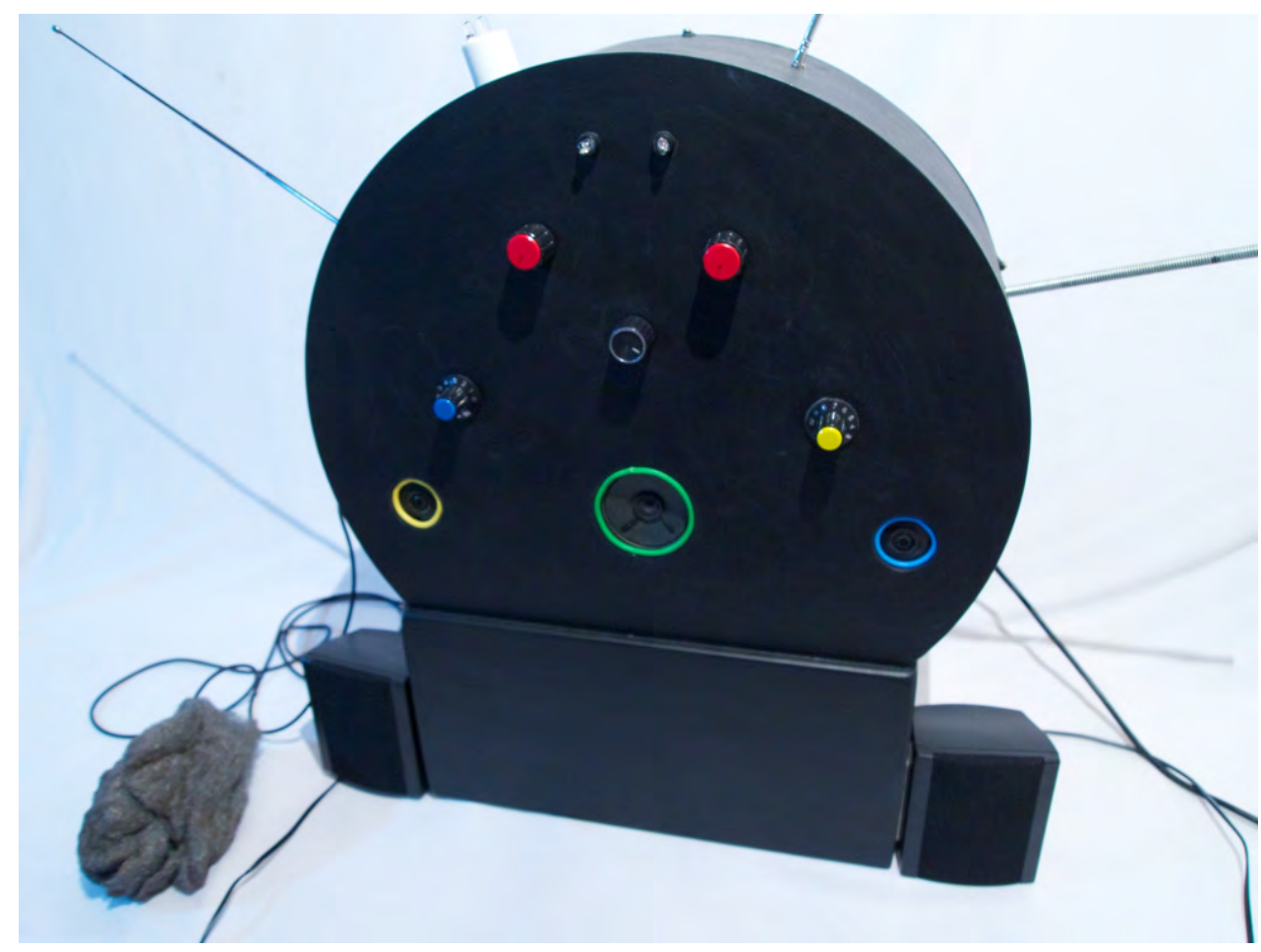

Figura 18 - Interface de controle utilizada em RevistaHertz, de Eduardo Néspoli e Maju Martins. Foto: Eduardo Néspoli.

apresentações baseadas em circuitos alterados por volta de $2006^{116}$. Sua atuação inclui uma dimensão educativa por meio de oficinas e cursos de formação, nos quais os participantes são incentivados a construir seus próprios instrumentos / obras de arte. Oficinas em SP no período 2008-2010 produzidas por Henrique Iwao (SILVEIRA; MUNIZ, 2011, p. 3).

Obici chama a atenção para o aspecto de "luteria modular" do trabalho de Pan\&Tone, através da construção de circuitos que possam interferir e interagir no funcionamento uns dos outros, mas também que possam ser transportados facilmente entre apresentações e oficinas realizadas em diversos lugares:

Nesse tipo de trabalho não é apenas a construção de dispositivos que faz parte da poética, mas também o fato de transportar e instalar fisicamente os objetos, o processo às vezes de "construí-los" ao vivo, bem como a performance para além do espaço e do momento de apresentação ${ }^{117}$.

Fernandez (2013, p. 162) enumera Pan\&Tone como um dos artistas mais atuantes no cenário brasileiro de Circuit Bending, e no período compreendido entre meados dos anos 2000 e meados dos anos 2010 são muitas as menções a oficinas e cursos ministrados pelo artista. Nos últimos anos, entretanto, esta atividade parece ter sido interrompida, e

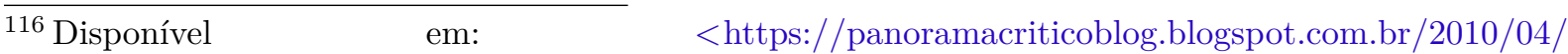
circuit-bending-com-cristiano-rosa-pan.html>. Acesso em 4 de março de 2018.

117 (OBICI, 2014, p. 156-157).
} 


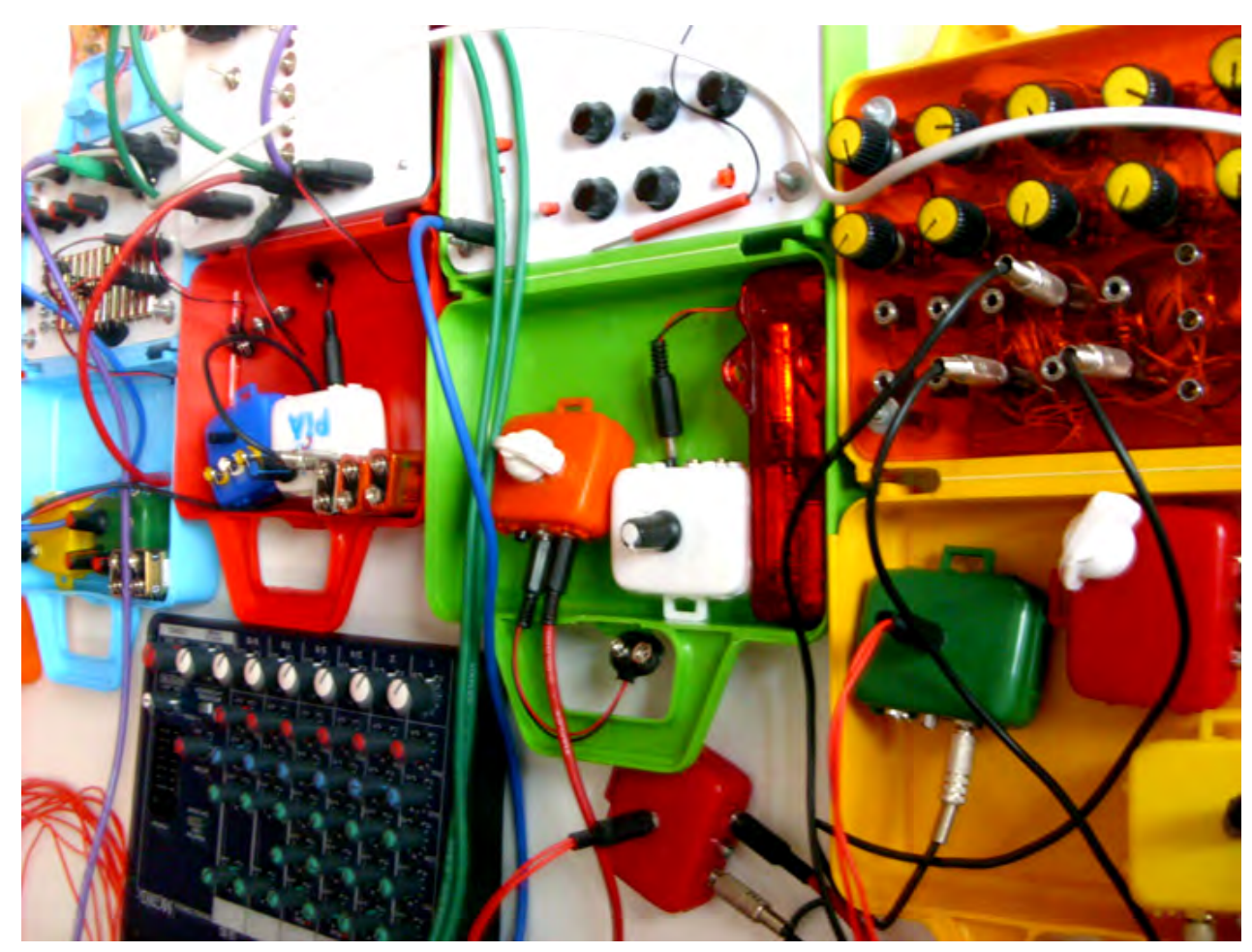

Figura 19 - Módulos de circuitos construídos por Pan\&Tone. Foto: Acervo Cristiano Rosa.

ao longo do período desta pesquisa não foram encontrados registros de atividades recentes, nem tampouco houve sucesso nas tentativas de contactar o artista.

\subsubsection{Marcelo Muniz}

Muniz possui formação em Física pelo Instituto Federal de São Paulo, tendo feito Mestrado e Doutorado em Neurociências e Comportamento na USP, com foco em cognição musical ${ }^{118}$, além de formação e vivência como violonista, com experiências em luteria tradicional ${ }^{119}$. Desenvolve desde os anos 2000 trabalhos de arte sonora e música experimental como criador, intérprete e também construtor de instrumentos e instalações em parceria com artistas, atividade na qual se define como bugiganguista.

Realiza oficinas de construção de equipamentos eletrônicos simples ${ }^{120}$ e de circuitos mais complexos, como Theremins ${ }^{121}$. Muniz se apresenta regularmente em duo com outros artistas - como Henrique Iwao, Cadós Sanches e o Brechó de Hostilidades Sonoras - e também realiza performances solo nas quais executa diversos instrumentos que construiu. A maioria de seus projetos tem como base a ideia de luteria low-tech, sendo desenvolvida

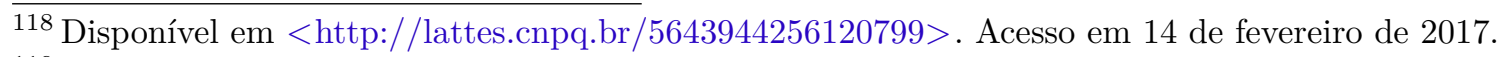

${ }^{119}$ Disponível em < http://www.festivalbigorna.com/2016/oficinas/>. Acesso em 11 de janeiro de 2017

${ }^{120}$ Disponível em: < http://www.fime.art.br/2016/pb/atividades-extras/>. Acesso em 14 de fevereiro de 2017.

${ }^{121}$ Disponível em: <https://www.sescsp.org.br/programacao/155039_CONSTRUINDO+UM+ THEREMIN $>$. Acesso em 26 de maio de 2018.
} 
a partir de sistemas eletrônicos simples com compontentes eletroeletrônicos rudimentares. Também é regularmente o facilitador de oficinas sobre temas ligados à sua produção.

\section{Projetos}

Bolo de noiva, 2009 Construído em parceria com Henrique Iwao e Thayane Oliveira. Consiste no empilhamento de toca-discos construídos artesanalmente, cada um dos quais contando com duas agulhas de reprodução diametralmente opostas, cujo áudio é processado por um patch no software $M a x / M S P^{122}$.

Tábua Mobile, 2010 Construída em parceria com Iwao e Borys Duque para o projeto temático MOBILE. Mesa desmontável de madeira na qual foram instalados captadores piezoelétricos, eletromagnéticos e microfones de eletreto, e que é executada com a manipulação de objetos diversos em sua superfície ${ }^{123}$.

Instrumental do Brechó de Hostilidades Sonoras Ver 2.3.16.

Página da internet < https://www.facebook.com/bandabrecho/>

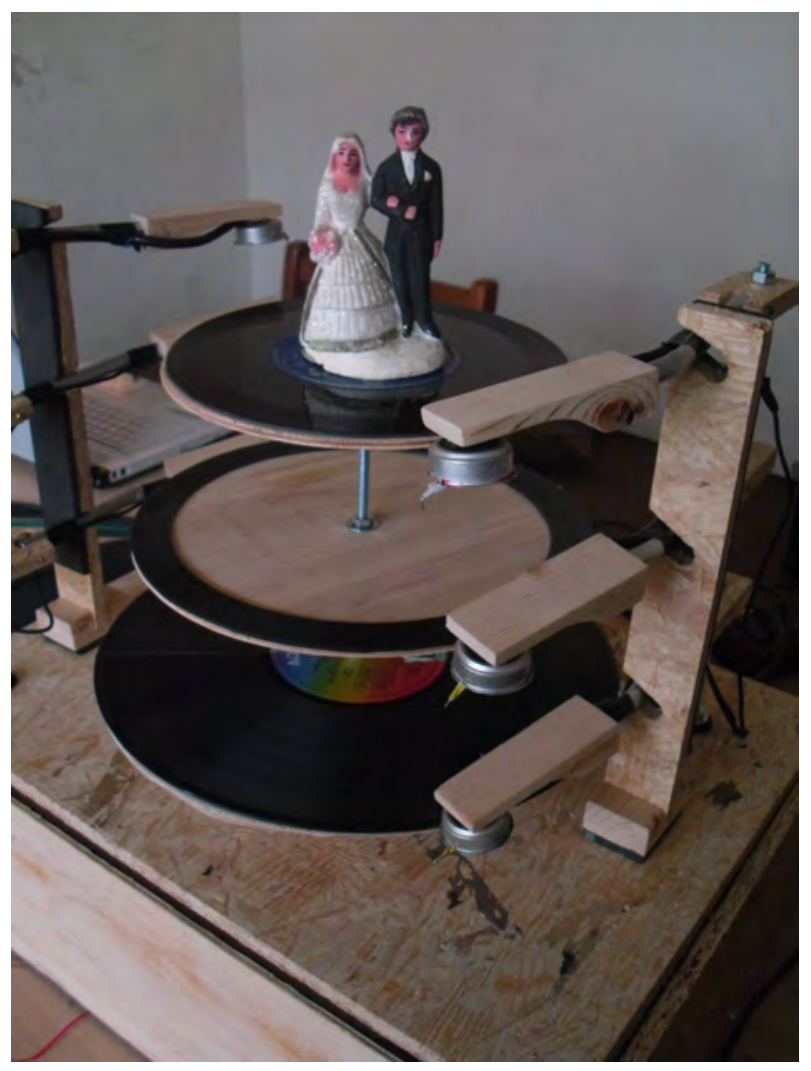

Figura 20 - O Bolo de Noiva. Foto: Henrique Iwao.

\footnotetext{
${ }^{122}$ Um vídeo de demonstração do Bolo de noiva está disponível em: < https://youtu.be/_siiL-yWHmU>. Acesso em 14 de fevereiro de 2017.

${ }^{123}$ Um vídeo de demonstração da Tábua Mobile está disponível em: <https://youtu.be/6IzH0SQ6UAQ> . Acesso em 14 de fevereiro de 2017.
} 


\subsubsection{Cadós Sanchez}

Cadós Sanchez Bandeira desenvolve instrumentos experimentais e plásticas sonoras para performances, espaços de exposição e instalações artísticas, numa abordagem que busca o cruzamento entre as diversas linguagens artísticas. Possui graduação em Artes Visuais pela FEBASP, e Especialização em História da Arte e Cultura Contemporânea ${ }^{124}$. Também atua como professor, tendo trabalhado no ensino fundamental e médio da rede pública em São Paulo por 10 anos, além de realizar oficinas em espaços diversos, como o Festival Bigorna e a Marcenaria do Ruben. Neste último espaço também desenvolve seu trabalho de construção de instrumentos experimentais e alguns projetos de luteria tradicional $^{125}$.

Segundo Sanchez, sua pesquisa em construção de instrumentos parte da experimentação com materiais diversos, como ponto de partida para desenvolver instrumentos que podem seguir abordagens mais próximas do tradicional ou experimentos com interfaces diferentes, como é o caso da Liga do Tempo. A esta categoria de instrumentos com interfaces pouco ortodoxas, Sachez dá o nome de Sonoramas.

Uma outra linha de atuação com relação a instrumentos musicais e performance são as Interfaces Sonoras em Situação de Rua, intervenções em casas abandonadas, terrenos baldios e espaços semelhantes, nos quais Sanchez e o também artista Marcos Amâncio tocam os objetos encontrados in loco:

para isso, levávamos diversas baquetas, arcos e algumas superfícies que construímos que ajudavam a ressoar os objetos [...] Recentemente utilizei os braços e motores que tocam a liga do tempo para tocar um piano abandonado em uma varanda de uma casa abandonada ${ }^{126}$.

\section{Projetos}

Liga do Tempo, 2012 Roda de bicicleta adaptada com molas, braços de madeira, motores e captadores diversos.

Contrabaixos experimentais Série de instrumentos que reaproveitam partes de contrabaixos elétricos ou acústicos, tendo suas caixas de ressonância ou corpos modificados.

Autômatos sonoros Série de autômatos sonoros que se utilizam de motores, captadores magnéticos e, em alguns casos, partes de instrumentos acústicos ${ }^{127}$.

\footnotetext{
$\overline{124}$ Disponível em: <http://lattes.cnpq.br/0626930031561398>. Acesso em 15 de fevereiro de 2017

${ }^{125}$ Disponível em <http://www.cadossanchez.com/bio-cados-sanchez $>$ e <http://lattes.cnpq.br/ $0626930031561398>$. Acesso em 16 de fevereiro de 2017

126 Cadós Sanchez, informação pessoal em 2 de março de 2018.

${ }^{127}$ Disponível em: < http://www.cadossanchez.com/automatos-sonoros $>$. Acesso em 16 de fevereiro de 2017
} 
Torre Série de instrumentos criados a partir de eixos Cardan de automóveis, reaproveitados. Às peças reaproveitadas são adicionadas cordas, captadores de contato e eletromagnéticos, e as cordas são erguidas por cavaletes semelhantes aos de instrumentos de corda friccionada. A execução do instrumento normalmente é feita na vertical - vide Figura 21 - com as cordas sendo ativadas por meio de um arco, sendo percutidas ou dedilhadas.

Skora Instrumento construído a partir de uma prancha de skate, à qual foram acrescentadas duas biribas de berimbau. Cordas são esticadas entre as biribas e a prancha, que também possui um sistema de captação com captadores piezoelétricos e eletromagnéticos. O nome faz menção à Cora, instrumento africano.

Página da internet < http://www.cadossanchez.com/>. Acesso em 14 de fevereiro de 2017.

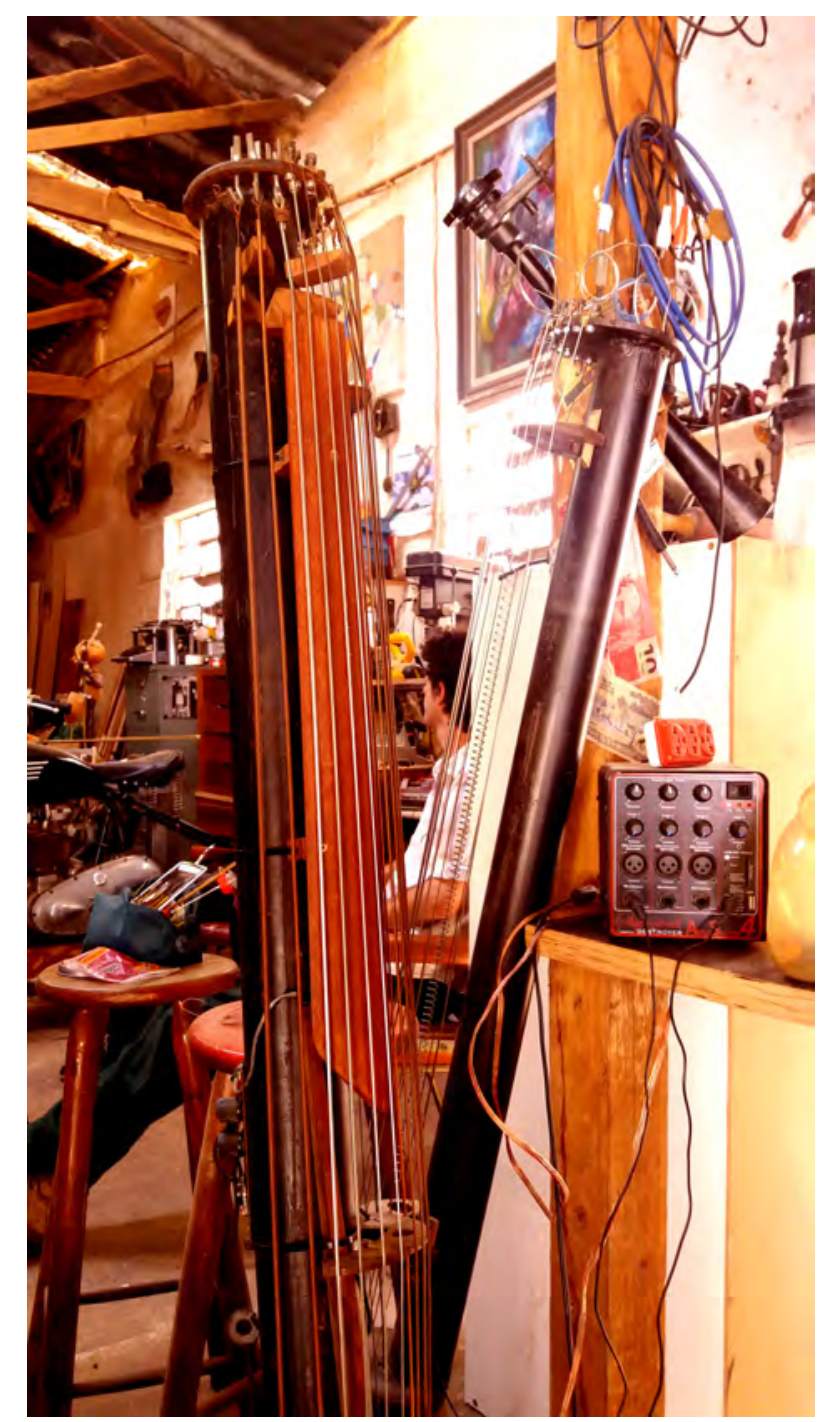

Figura 21 - Torres feitas a partir de eixos Cardan, na marcenaria do Ruben. Foto do autor. 


\subsubsection{André Damião Bandeira}

André Damião é um artista cuja produção cruza os limites entre software e hardware, e que trabalha "de maneira transversal entre os campos da música e da arte com novas mídias" ${ }^{28}$. Seu trabalho com linguagens de programação até 2013 é discutido por mim em Lima (2013, p. 88-97), período após o qual o artista desenvolve uma série de objetos de performance e instrumentos musicais combinando diversas técnicas de alteração de circuitos e processamento de sinais, documentada em sua dissertação de mestrado ${ }^{129}$. Descrevo aqui os "objetos sonoros de Música Móvel Crítica"130 Narva 1 e Narva 2.

\section{Projetos}

Narva 1 Combina discos pré-gravados tocados em um toca-discos normal, com as agulhas convencionais sendo substituídas por captadores piezoelétricos aos quais foram acrescentados pregos para desempenhar o papel das agulhas. O sinal é processado em um software instalado em um telefone celular, e o resultado é reproduzido em um alto-falante portátil, acoplado ao celular. Imagens e exemplos sonoros podem ser ouvidos em <http://andredamiao.hotglue.me/narva1 $>{ }^{131}$.

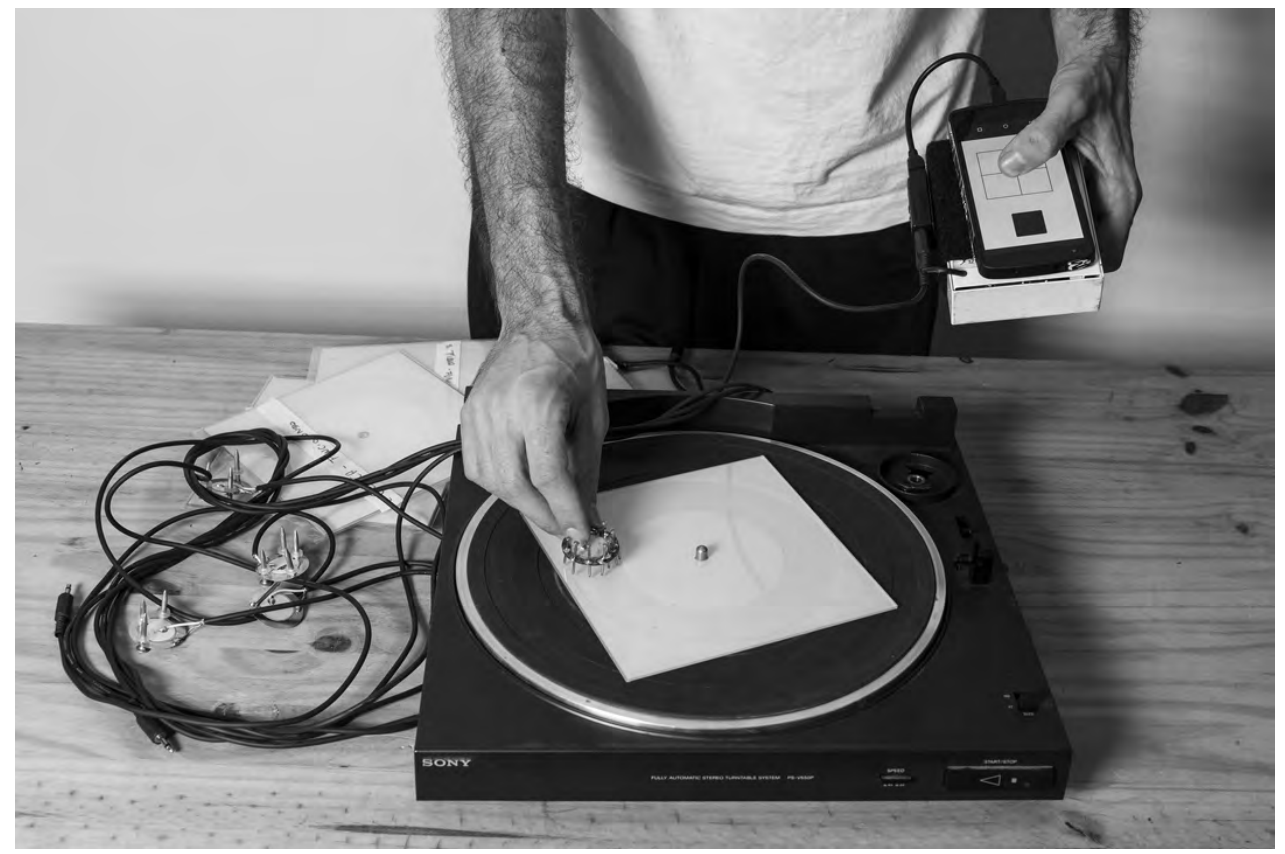

Figura 22 - Narva 1. Foto: André Damião Bandeira.

Narva 2 Feito a partir de uma televisão portátil descartada, cujo funcionamento regular foi extendido através do acoplamento de microcontroladores e de um

\footnotetext{
$\overline{128}$ Disponível em:<https://issuu.com/andredamiaobandeira/docs/cv_damiao2016>. Acesso em 11 de maio de 2018

129 (BANDEIRA, 2015)

130 (BANDEIRA, 2015, p. 74). Segundo Bandeira, o nome Narva é uma menção à uma fábrica de lâmpadas na Alemanha Oriental que não aderiu à prática de obsolescência programada.

${ }^{131}$ Acesso em 11 de maio de 2018.
} 
microcomputador. Imagens e exemplos sonoros podem ser ouvidos em $<$ http: //andredamiao.hotglue.me/narva2 $>{ }^{132}$.

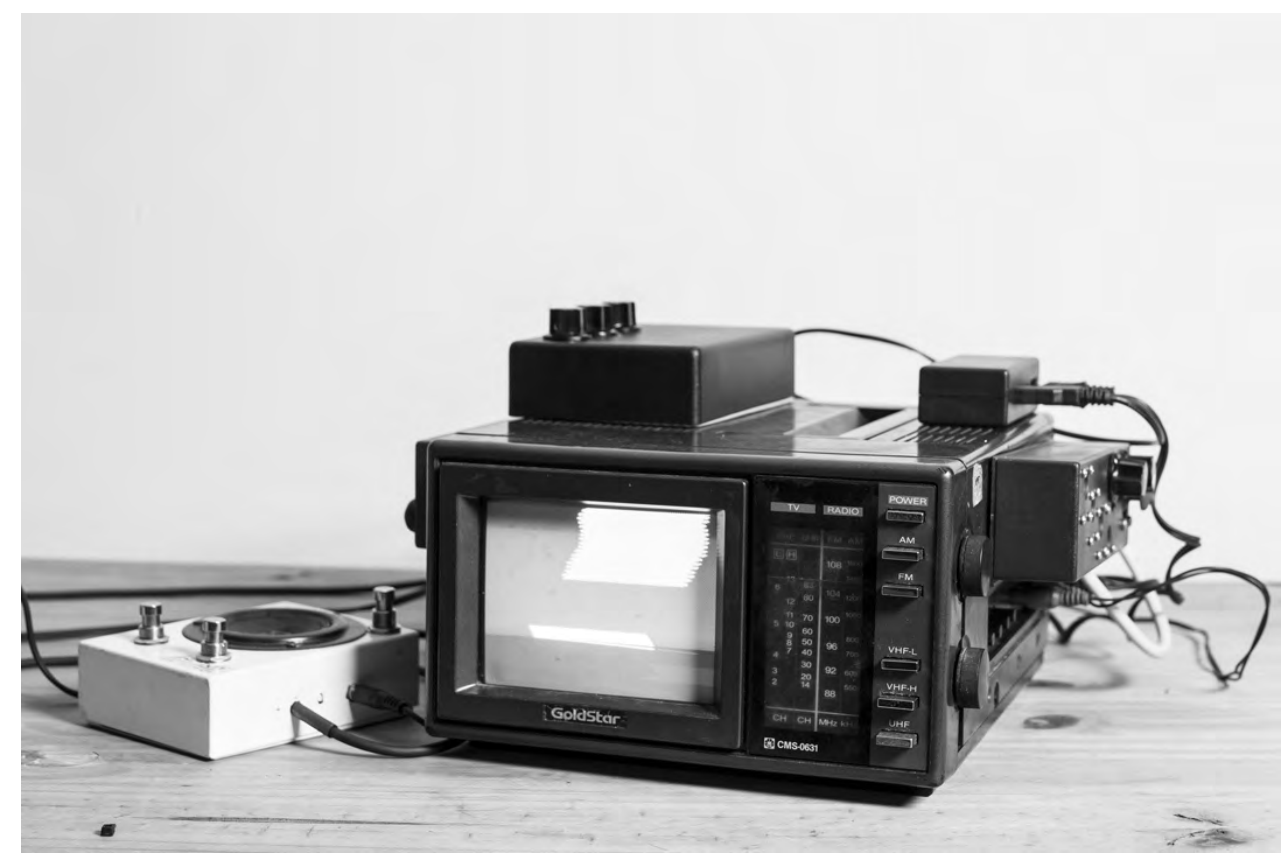

Figura 23 - Narva 2. Foto: André Damião Bandeira.

Página da internet <http://andredamiao.hotglue.me/>

\subsubsection{Eloi Silvestre}

Eloi Silvestre Chiquetto, nascido em São Paulo em 13 de maio de 1966, possui formação em eletrônica em nível técnico e atua como profissional na área de informática e como tarólogo. Seu processo de criação de instrumentos parte de um interesse pessoal em eletrônica e na experimentação com circuitos produtores de som: "sempre me agradaram os ruídos das máquinas e dos osciladores caseiros que eu montava, e isso foi me levando a conhecer músicos que me chamaram para tocar junto" ${ }^{133}$. Os instrumentos em si são resultado de uma processo de tentativa e erro a partir de materiais diversos como circuitos eletrônicos, dispositivos já existentes e objetos eletroeletrônicos em geral.

Integrou o grupo LCD, formado em 2000 juntamente com Paulo Beto e Miguel Barella, ao qual se juntou posteriormente o artista de vídeo Kiko Araújo, cuja proposta é desenvolver uma pesquisa "na área de improvisação livre com linguagem eletrônica experimental e abstrata"134.

\footnotetext{
132 Acesso em 11 de maio de 2018.

133 Eloi Silvestre, informação pessoal via Facebook Messenger em 06 de março de 2018.

134 Disponível

em:<https://mundoestranhodepb.blogspot.com.br/2009/02/ ze-do-caixao-e-lcd-lcd-encontra-ze-do.html>. Acesso em 6 de março de 2018.
} 
Projetos Percussiomixer Instrumento criado a partir da mistura de uma botoeira de semáforo de pedestres, iluminação de jardim, um velho motor de mixer de cozinha - com rotação controlada por um dimmer -, e uma série de implantes na parte externa da luminária de jardim, como uma lata antiga de negativo, partes giratórias de um antigo videocassete, lâmina de metal e uma campainha feita de uma mola e uma forminha de empada. A captação era feita pela bobina reaproveitada de um galvanômetro. Podia ser tocado percussivamente (batendo), girando as peças de videocassete, além da possibilidade de ligar o motor do mixer através da botoeira e alterar o som usando o controle do dimmer.

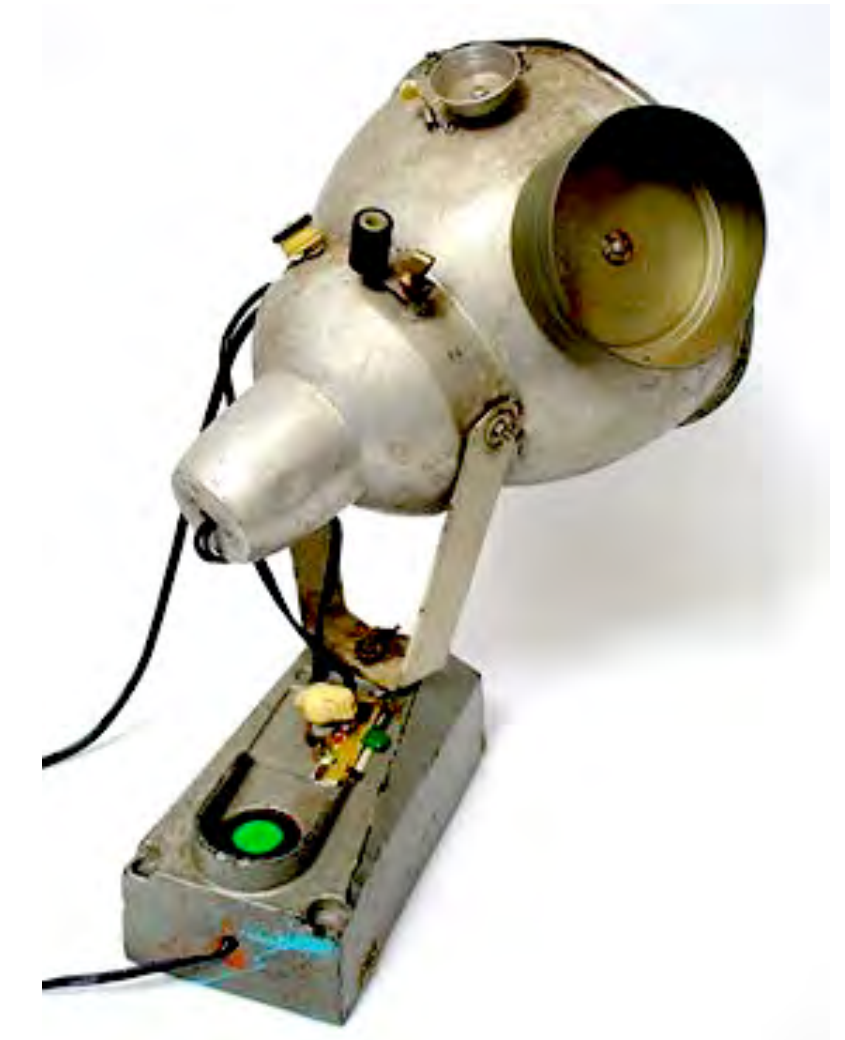

Figura 24 - O Percussiomixer. Foto: Eloi Silvestre.

Polyradiotron 2 antigos rádios AM com os circuitos expostos, que se interferiam mutuamente. Além do som produzido pela interferência de um rádio no outro, era possível alterar o som colocando os dedos nas partes expostas do circuito, provocando efeitos similares ao som do Theremin. Também haviam 3 motores de corrente contínua, que ficavam próximos aos rádios e que produziam som pela interferência. A rotação dos motores era controlada por um velho acelerador de autorama. 


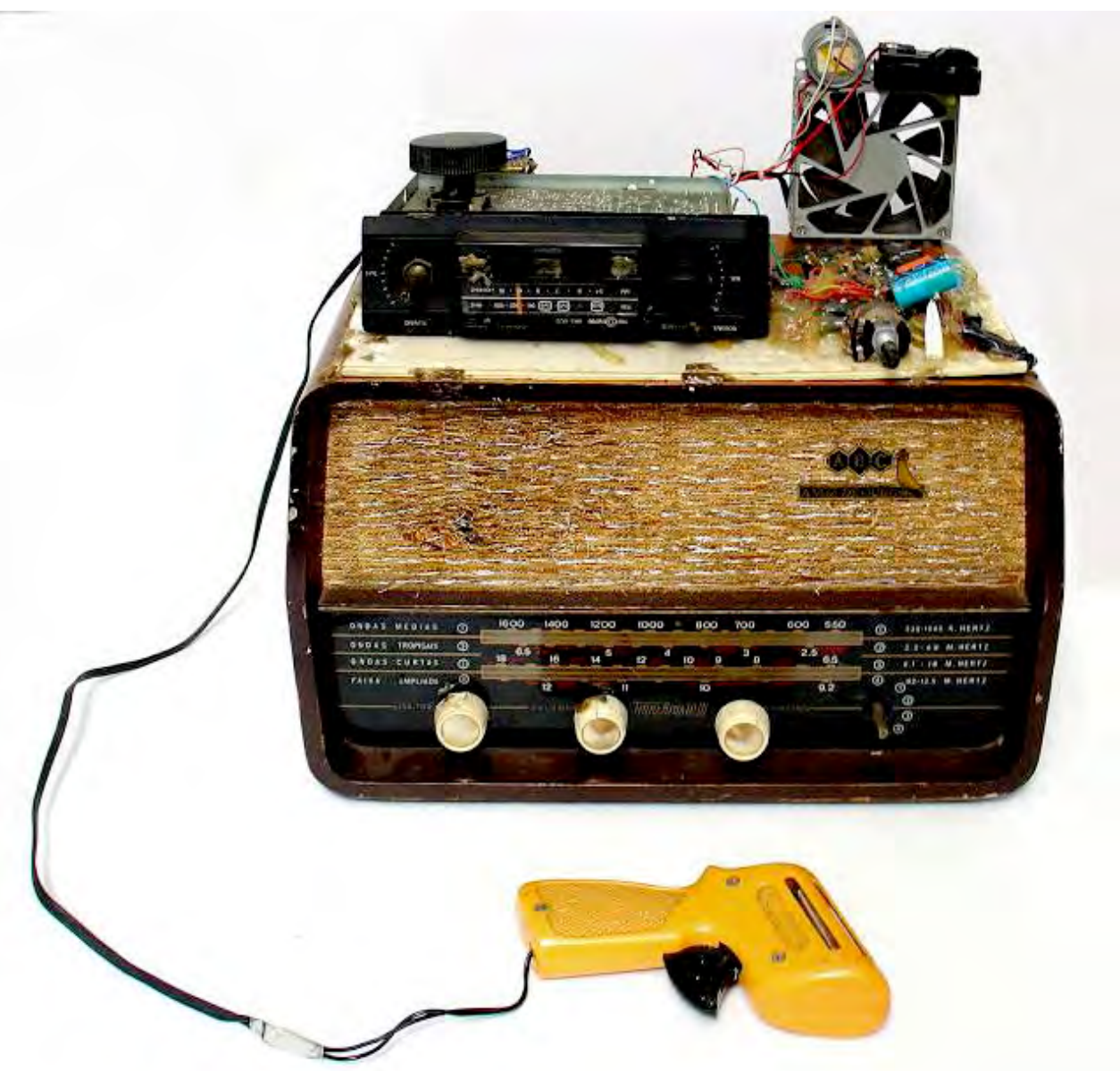

Figura 25 - O Polyradiotron. Foto: Eloi Silvestre.

\subsubsection{Paulo Nenflídio}

Nascido em 1976 em São Bernardo do Campo - SP, Paulo Nenflídio é um artista que trabalha com construção de autômatos e aparelhos sonoros, que por vezes transcendem os limites da arte voltada para as galerias e integram performances musicais ${ }^{135}$ :

Sou construtor sonoro e cinético. Porém, seria no meu caso mais confortável dizer que sou inventor apenas, pois algumas vezes extrapolo os limites destas categorias em minha produção. Como busco sempre a poesia, então artista inventor é a melhor definição. ${ }^{136}$

Em suas obras trabalha com diversos níveis materialidade e dispositivos, combinando materiais como madeira, metal, plástico com circuitos de eletrônica analógica e, mais recentemente, a programação de sistemas digitais embarcados em suas obras ${ }^{137}$. Obici utiliza o termo "instru-menta-lações" para descrever as criações de Nenflídio, ressaltando

\footnotetext{
135 Alguns exemplos estão disponíveis em $<$ http://www.youtube.com/user/nenflidio $>$. Acesso em 01 de outubro de 2013.

136 Nenflídio apud Scarassatti (2015, p. 182)

${ }^{137}$ Nenflídio apud Scarassatti (2015, p. 183)
} 
seu duplo aspecto como instalação sonora e instrumento musical, que pode responder à ação de intérpretes-participantes, não necessariamente humanos: "o aspecto interativo existe a partir da ação do visitante ou de elementos e fenômenos naturais (vento, luminosidade, gotejamento, retroalimentação)"138.

\section{Projetos}

Telembau Dupla de berimbaus elétricos, conectados cada qual a um comunicador portátil do tipo walkie-talkie. A performance nestes instrumentos se estrutura através de um diálogo entre os intérpretes dos dois instrumentos, cada um sendo executado por sua vez, com o som do telembau de um intérprete sendo transmitido e reproduzido no walkie-talkie do outro, que escuta e responde na sequência. O telembau original foi estreado no concerto ¿Música? no CMU da USP, em 26 de maio de 2006, tendo como intérpretes Vitor Kisil e Giuliano Obici ${ }^{139}$. Desdobramentos do instrumento surgem na obra de Nenflídio, como o Telembauzin, com instrumentos menores, o Telembau Gunga e o Telembau Telegráfico ${ }^{140}$.

Teclado sísmico Instrumento que conecta uma interface de teclado a seis britadeiras, montadas na extremidade de seis "pernas" de uma escultura que lembra o aspecto de um aracnídeo gigante. Lâmpadas incandescentes acendem de acordo com a intensidade com que cada tecla é acionada pelo usuário ${ }^{141}$.

Página da internet <http://paulonenflidio.tumblr.com/>

\subsubsection{Arthur Joly}

O paulistano Arthur Joly é conhecido por seu trabalho como construtor de sintetizadores analógicos em diversos formatos, e sua produção é utilizada por artistas de diversos estilos ${ }^{142}$. Seu envolvimento com a construção de sintetizadores está relacionado com o interesse neste tipo de instrumento ao longo da carreira de Joly como publicitário e produtor musical, associado a experiência com aeromodelismo e outros hobbies semelhantes $^{143}$. A partir da impossibilidade de importar um sintetizador modular - devido ao alto custo envolvido - surge a motivação para construir pequenos projetos a partir de kits de sintetizadores disponíveis para venda online, e eventualmente Joly estabelece uma relação com alguns projetistas e fabricantes de sintetizadores pela internet, como o website Music

\footnotetext{
138 (OBICI, 2014, p. 147)

139 (MISKALO, 2014, p. 110-111)

140 Disponível em: < http://paulonenflidio.tumblr.com/imagens>. Acesso em 26 de maio de 2018.

${ }^{141}$ Disponível em: <http://paulonenflidio.tumblr.com/>. Acesso em 27 de maio de 2018

142 Disponível em: < http://www.recosynth.com/>

${ }^{143}$ Informação pessoal em 17 de agosto de 2016. Um histórico resumido da produção fonográfica de Arthur Joly e do selo Reco-head está disponível em <http://reco-head.blogspot.com.br>. Acesso em 18 de agosto de 2016 .
} 


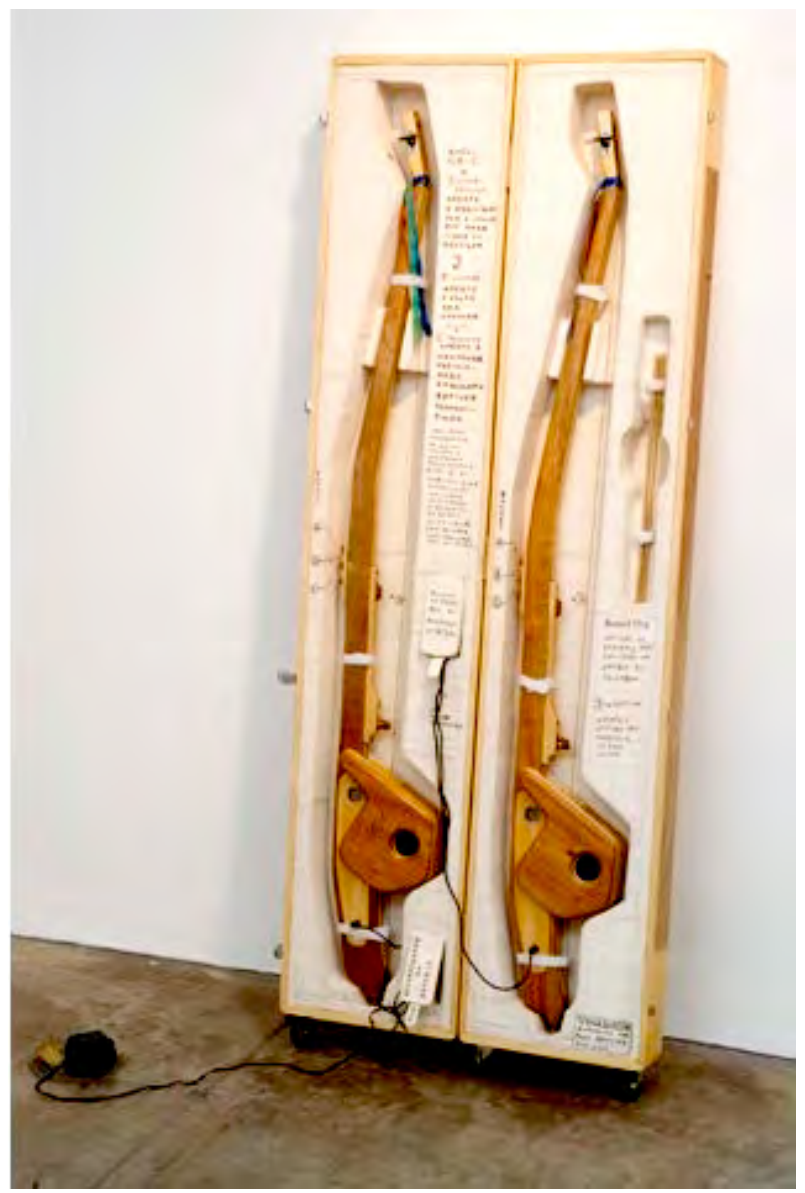

Figura 26 - Dupla de Telembaus construídos por Paulo Nenflídio. Foto: Galeria Fortes Vilaça.

from Outer Space ${ }^{144}$ e seu mantenedor, Ray Wilson. Este processo de construção de kits e sintetizadores começa em 2009, quando Joly também dá início a construção de um projeto mais ambicioso, o sintetizador modular Jolymod ${ }^{145}$. Além de sintetizadores, Joly também constrói unidades de processamento de som como reverberadores de mola e outros efeitos de áudio. Estes são produzidos em série, assim como o sintetizador "Piranha" e versões do projeto "Atari Punk Console". Seu conhecimento de eletrônica foi desenvolvido à medida em que ganhou experiência com a construção dos kits e instrumentos, não possuía conhecimento extenso prévio nem estudou especificamente para este fim.

\section{Projetos}

Série Jolymod O sintetizador Jolymod é um sintetizador modular montado por Joly em São Paulo, a partir da adaptação de projetos e kits já existentes, a partir da vontade do construtor de criar e tocar um sintetizador modular. Foi

\footnotetext{
144 Disponível em: <http://www.musicfromouterspace.com/>. Acesso em 17 de agosto de 2016

${ }^{145}$ Disponível em: < https://thump.vice.com/pt_br/article/colecao-de-sintetizadores-de-arthur-joly $>$. Acesso em 17 de agosto de 2016.
} 


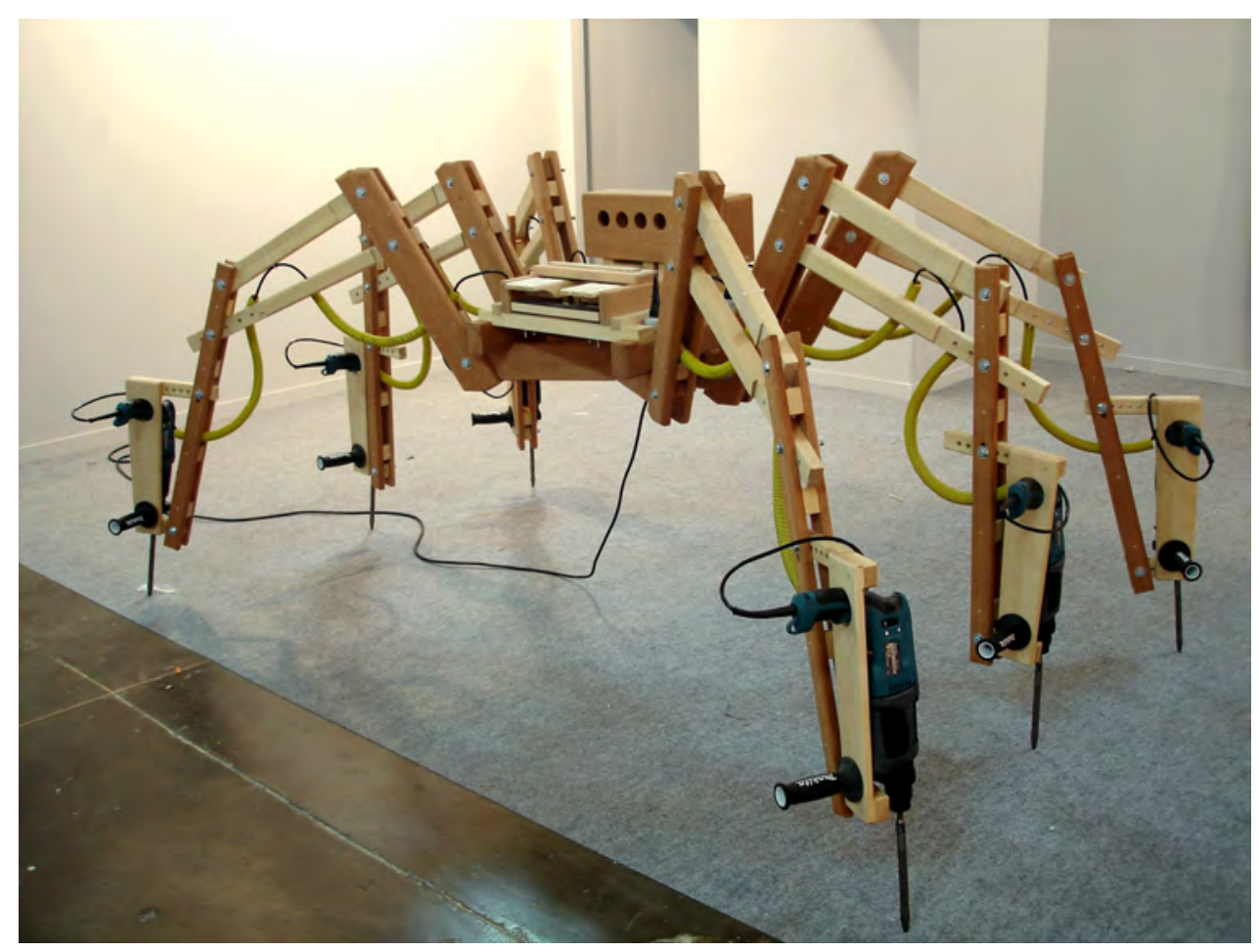

Figura 27 - Teclado sísmico construído por Paulo Nenflídio. Foto: Paulo Nenflídio.

o primeiro de uma série de quatro sintetizadores, construídos por Joly neste formato $^{146}$.

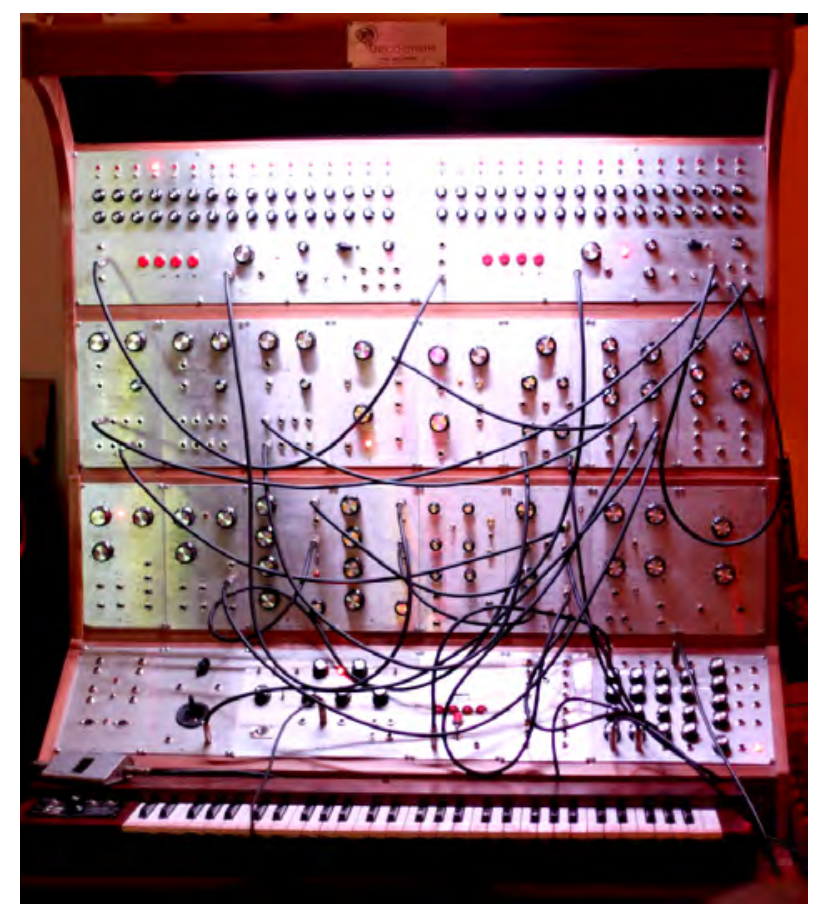

Figura 28 - O sintetizador Jolymod II. Foto: Arthur Joly.

$\overline{146}$ Um vídeo de apresentação do Jolymod I pode ser visto em < https://vimeo.com/27843302>. Acesso em 13 de maio de 2014. 
Série Recosynths Série de sintetizadores compactos construídos por Joly utilizando diversos tipos de carcaças de objetos reaproveitadas, para as quais adapta projetos de sintetizador a partir de kits ou esquemas eletrônicos. Nesta série existe uma preocupação com a unicidade do resultado final, uma "vontade de fazer um instrumento único, tanto visualmente como também que soe diferente, e que seja uma peça que ninguém vai ter uma igual"147. Juntamente com estas peças únicas, em torno de 30 até o momento, Joly habitualmente produz vídeos de apresentação de cada uma destas peças, e também da produção de música com algumas delas ${ }^{148}$.

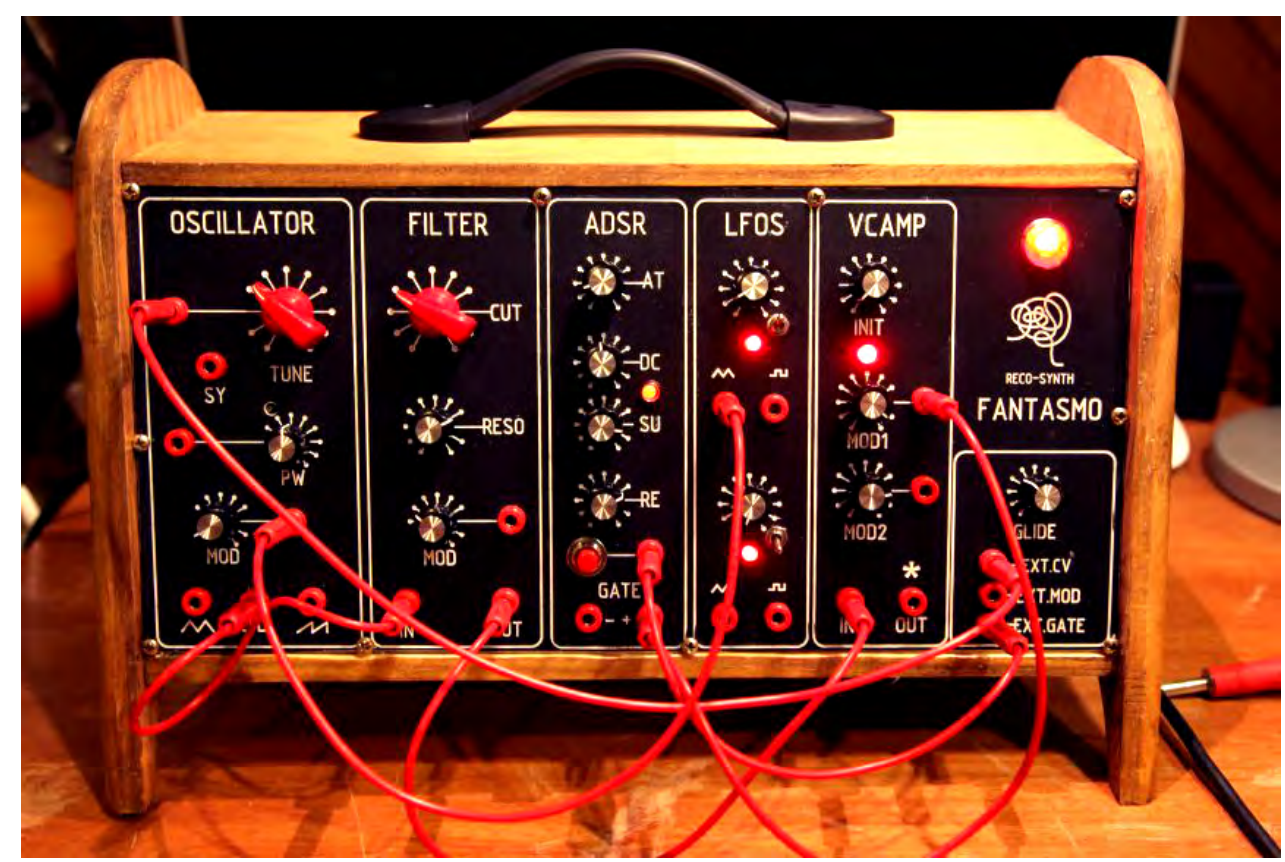

Figura 29 - O sintetizador Fantasmo. Foto: Arthur Joly.

Página da internet <http://www.recosynth.com/ $>$

\subsubsection{Batebit Artesania Digital}

Batebit Artesania Digital é um coletivo formado por Felipe Calegário, João Tragtenberg e Jerônimo "Jeraman" Barbosa ativo em Recife, Pernambuco, no período 2012-2015 e retomado por Calegário e Tragtenberg a partir de 2017, ainda em atividade. O coletivo atua na construção de instrumentos musicais digitais tocados por meio de interfaces de controle criadas a partir da pesquisa e desenvolvimento junto a músicos atuantes no cenário musical recifense. Assim como o grupo de pesquisas do qual germinou, o MUSTIC ${ }^{150}$, o

\footnotetext{
${ }^{147}$ Disponível em <https://youtu.be/6FxGErdwNFc > . Acesso em 19 de agosto de 2016

148 Os canais de Joly nos websites Vimeo e YouTube apresentam uma vasta coleção destes vídeos. Disponível em: <https://vimeo.com/arthurjoly> e <https://www.youtube.com/user/RecoHead>. Acesso em 6 de fevereiro de 2017.

149 Disponível em: < http://batebit.cc/>. Acesso em 06 de julho de 2015.

${ }^{150}$ Disponível em: < http://www.mustic.info/about/>. Acesso em 27 de maio de 2018.
} 
Batebit desenvolve suas atividades em paralelo com a atividade de pesquisas acadêmicas ligadas à UFPE, instituição da qual Calegário, Tragtenberg e Barbosa foram alunos.

Uma característica dos projetos desenvolvidos pelo Batebit é a disponibilização, em seu sítio na internet, da documentação de todo o processo de construção dos instrumentos criados pelo grupo, e também de tutoriais para a construção de instrumentos semelhantes em <http://batebit.cc/processo/tutorial/ $>^{151}$. Tanto a pesquisa de Calegario (2017) quanto a de Tragtenberg (2018) tratam de questões relacionadas com o design e construção de instrumentos musicais digitais.

\section{Projetos}

Tumtá e Pisada Interfaces desenvolvidas em conjunto com o músico e bailarino Hélder Vasconcelos para uso em espetáculos de dança. O Tumtá é uma interface de controle vestível na forma de palmilhas que são calçadas pelo usuário, e o Pisada consiste em pads dispostos no chão do espaço de dança. As duas interfaces trabalham em conjunto no processo de seleção e disparo de bancos com amostras sonoras ${ }^{152}$.

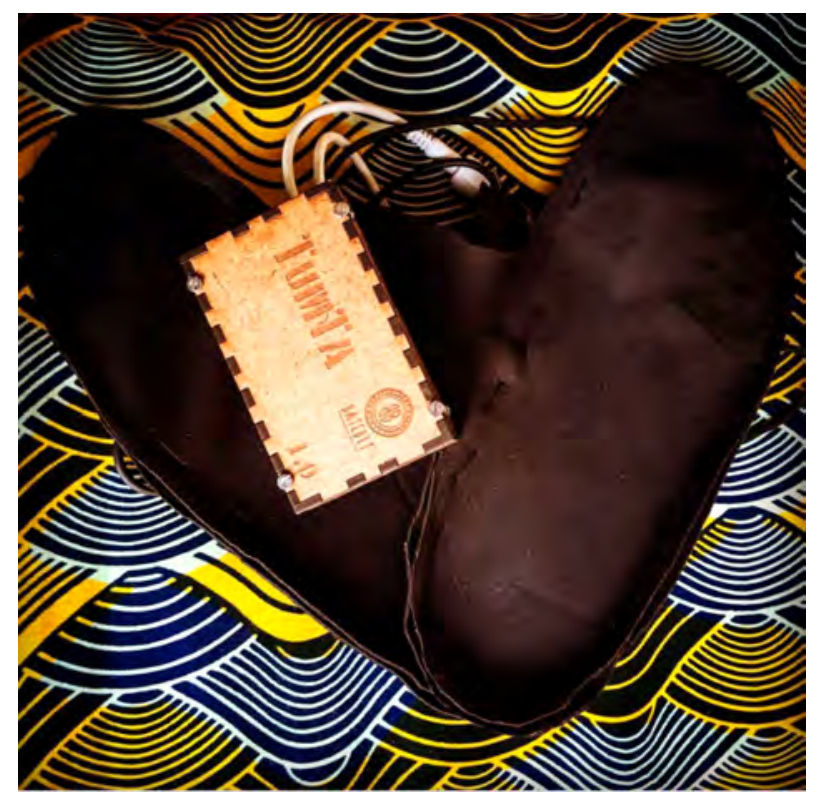

Figura 30 - Palmilhas e transmissor da interface vestível TumTá. Foto: Batebit.

Disque-Som Interface de controle feita a partir de um aparelho telefônico reaproveitado, no qual o teclado numérico original é convertido em um teclado MIDI de três oitavas de extensão, outros controles são adicionados, e o microfone e o altofalante no gancho podem ser usados como entrada e saída de áudio. O

\footnotetext{
151 Acesso em 27 de maio de 2018

152 Disponível em: < http://batebit.cc/instrumento/tumta/> e < http://batebit.cc/instrumento/pisada/ > . Acesso em 27 de maio de 2018
} 
protótipo do Disque-Som é um exemplo interessante de ressignificação de um objeto de uso comum, tendo sido feito a partir do aparelho telefônico da famíla de João Tragtenberg.

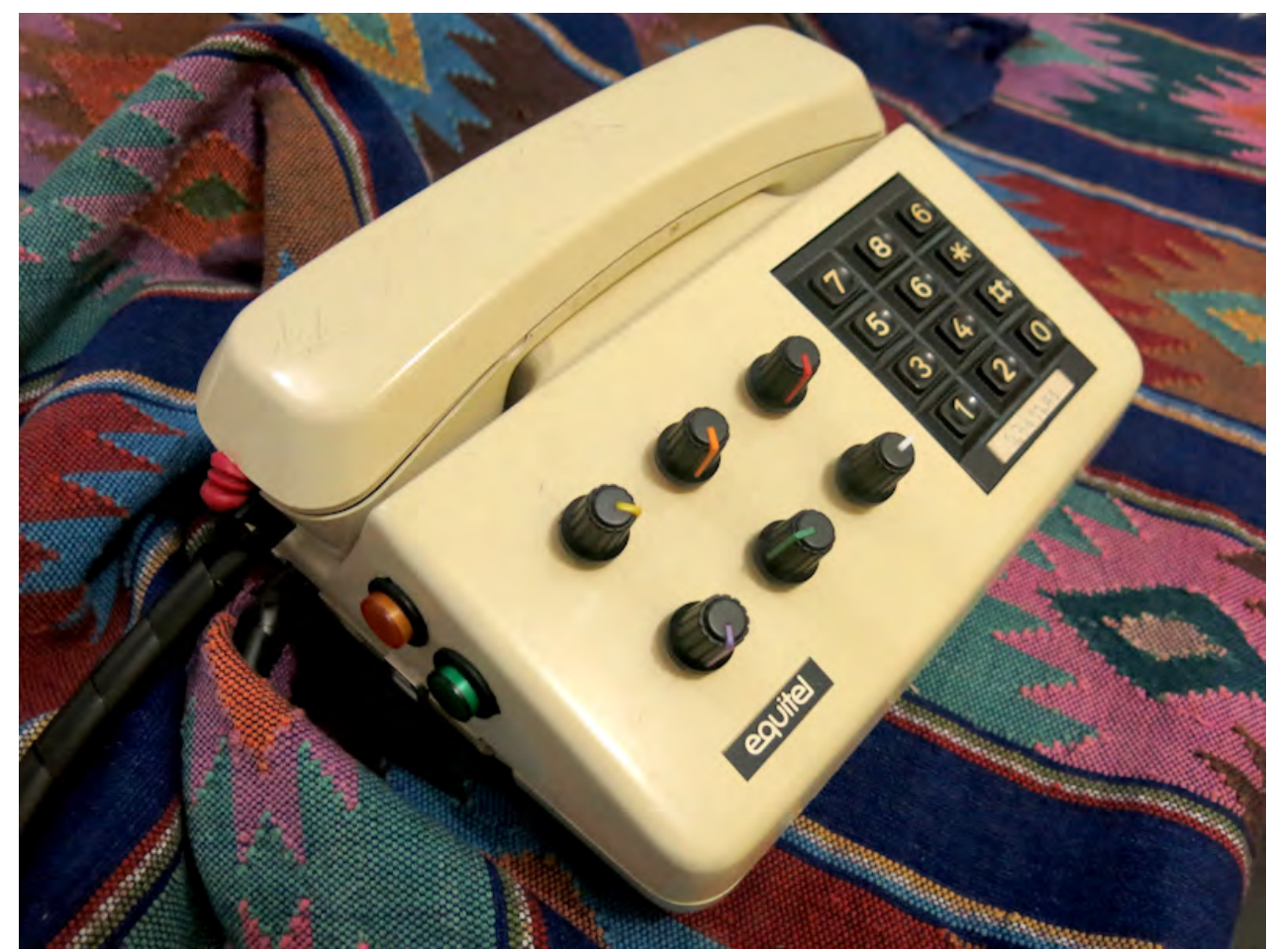

Figura 31 - Controlador Disque-som. Foto: Batebit.

Página da internet <http://paulonenflidio.tumblr.com/>

\subsubsection{Brechó de Hostilidades Sonoras}

Duo formado por Marcelo Muniz e Natacha Maurer em atividade desde 2015, a partir do intercâmbio de ideias e da parceria de Muniz e Maurer nos eventos do Ibrasotope ao longo dos anos. O nome do duo possui relação com a premissa de reaproveitamento de materiais, em especial brinquedos e aparelhos sonoros adquiridos em feiras de troca e venda de objetos usados e de segunda mão, locais estes que servem de inspiração estética devido ao seu "caos plástico-sonoro"153.

Suas atividades são baseadas em ciclos anuais ao longo dos quais uma série de instrumentos é desenvolvida para depois ser deixada de lado, ou reutilizada por outros $\operatorname{artistas}^{154}$. Do primeiro ciclo destacam se a dupla de bonecas crackebox Jezebel Crackletoy e Rosemary, bonecas em formato de bebê nas quais foram montados circuitos

\footnotetext{
${ }^{153}$ Disponível em: < https://www.facebook.com/pg/bandabrecho/about/?ref=page_internal>. Acesso em 14 de fevereiro de 2017.

${ }^{154}$ Disponível em:

<http://www.ovolumemorto.com/single-post/2016/10/31/ usado-e-de-segunda-m ao-entrevista-com-brechó-de-hostilidades-sonoras $>$. Acesso em 14 de fevereiro de 2017.
} 


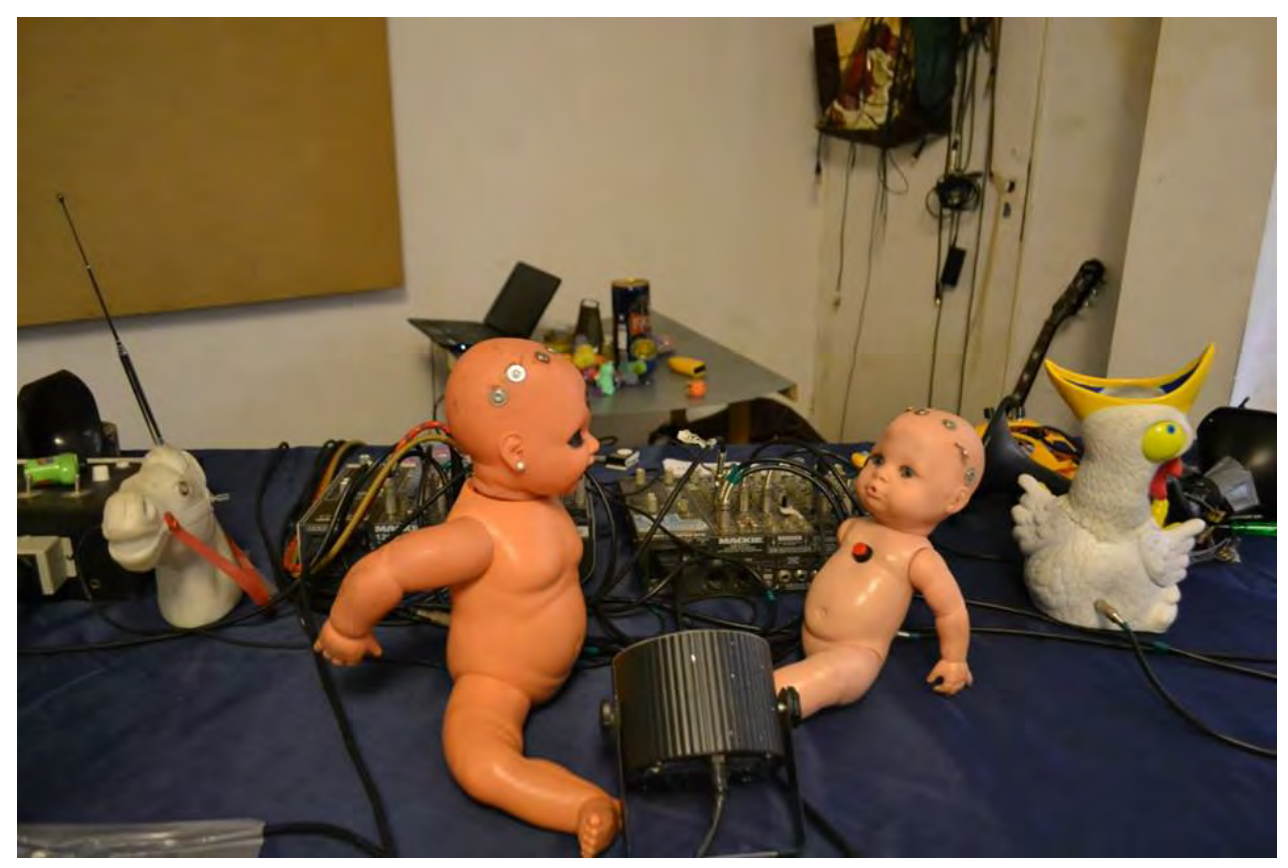

Figura 32 - As bonecas Jezebel Crackletoy e Rosemary do Brechó de Hostilidades Sonoras. Foto: BHS.

geradores de som, estes acionados a partir de eletrodos colocados na cabeça das bonecas, em um sistema semelhante ao da Cracklebox, uma placa metálica amplificada que é utilizada de modo semelhante à Tábua Mobile, adaptação de manequins.

\subsection{Pontos de análise - 2}

O cenário descrito neste capítulo revela uma grande variedade de abordagens no tocante à criação de instrumentos nas últimas duas décadas no Brasil e, seja pelo esforço de pesquisadores, seja pelo interesse dos próprios artistas, este é um cenário que possui uma articulação interna no que diz respeito ao compartilhamento de saberes e meios de viabilizar esta produção. Retomando um ponto discutido em 1.5 acredito que há um interesse coletivo na existência destes instrumentos, nas formas como estes instrumentos vêm a existir, e nos modos como estes instrumentos se tornam mediadores dos artistas que os criam.

Acredito ser importante chamar a atenção neste ponto sobre a importância destes dispositivos na criação de um cenário de construção de instrumentos, e que são estes objetos que acabam promovendo a articulação entre seus participantes, o que pode ser observado no espaço da oficina. Este caráter social do fazer artístico é uma parte importante dentro da prática de luteria experimental, e da postura faça-você-mesmo aplicada à eletrônica.

Tanto o espaço de performances quanto ambiente da oficina, neste cenário, podem ser vistos como esforços no sentido de criar ambientes de relacionamento que tem como 
base a criação e o uso de objetos relacionados ao fazer sonoro e musical. A importância do aspecto relacional nestes ambientes é discutido por Fernandez (2013, p. 116-133) em relação ao cenário de alteração de circuitos, mas acredito que estas características permeiam a atividade de muitos dos artistas descritos acima. Scarassatti também reconhece a busca por um coletivismo como uma característica dos ambientes de construção e execução de instrumentos ${ }^{155}$, mas que pode ser visto também na criação de instrumentos coletivos e instalações penetráveis e manipuláveis pelo público. Outro aspecto deste coletivismo tem a ver com a criação sonora coletiva e improvisada, no que Fernandez (2013, p. 103) e Scarassatti (2008, p. 26) citam uma máxima de Smetak: "O imprevisto é irmão da improvisação".

A variedade de abordagens no cenário também possui uma relação com o que Obici chama de "usuário-inventor-ressignificante"156. Permito-me extrapolar o termo proposto por Obici, que em seu contexto original é utilizado para descrever a postura do usuário dos objetos ressignificados no contexto cubano, para propor seu uso como referência para entender a atividade dos artistas aqui citados. Em diversos casos, esta postura política de usuário-inventor-ressignificante não se limita à ressignificação dos objetos, mas também dos meios e das técnicas utilizadas na criação destes objetos, assim como em seu uso. Em alguns dos casos estudados até agora, proponho que a ressignificação começa em estruturas subjacentes como espaços físicos ou mesmo conceitos: terreno baldio, marcenaria, homembanda, sillon fermé são ressignificados por meio da ideia de instrumento musical como as ISSRs de Sanchez e Amâncio; a transposição de limiares do fazer artístico no espaço de trabalho de Ruben Pagani; o ecossistema sonoro da Geralda; o comentário sobre a materialidade dos loops musicais feitos à mão por instrumentos como o ritmifiqueitor ou pelo bolo de noiva.

Instrumentos como as Torres feitas por Cadós Sanchez e Rubem Pagani não somente possuem esse aspecto de ressignificação dos objetos que as constituem mas também são viabilizados pela ressignificação de técnicas de construção herdadas da luteria tradicional, e de técnicas de execução de instrumentos tradicionais. Estas técnicas originalmente desenvolvidas para produzir e utilizar instrumentos estabelecidos, pertencentes a uma tradição instrumental específica, são ressiginificados no momento em que agenciam uma família de instrumentos em constante mutação. A Geralda, por exemplo, é um grande penetrável ressignificante, tanto de objetos quanto de técnicas instrumentais e de mediação tecnológica do som.

Esta relação entre instrumento-dispositivo e seu músico-usuário é entendida por Scarassatti (2015, p. 149) como uma dialética:

O que faz o instrumento musical senão produzir o músico que o toca, determinando-o

155 (SCARASSATI, 2008, p. 125)

156 (OBICI, 2014, p. 18) 
como músico, modelando, controlando e assegurando seus gestos e condutas no ato de tocar? De um lado, o conceito de música produz o dispositivo que a "toca"; de outro, o dispositivo instrumento musical tece a rede simbólica e ideológica que conceitua e produz a própria música e implica também um processo de subjetivação, isto é, produz o sujeito que a faz.

Outro tema transversal que observo é a de que as abordagens aqui mencionadas são limítrofes, lidam com os limites do instrumento musical como ente estabelecido, e expõe seus limites e fronteiras estabelecidos. Esta é uma característica que já é observada na produção de Smetak por Scarassatti (2008, p. 139) e por Obici (2014, p. 112-116) e, ainda que não exista uma influência direta de Smetak em todos os artistas aqui mencionados, é possível especular que a obra deste artista seja pioneira no sentido de sintonizar e demonstrar determinados aspectos da criação artística voltada para o sonoro que permeia a produção na contemporaneidade: o cenário aqui descrito depende de uma disponibilidade de materiais que é característica dos tempos atuais, e as sobras e excessos que são articuladas por este tipo de manifestação e de pensamento artístico são característicos das sociedades hiperindustrializadas. O que muda neste sentido do período de Smetak para os tempos atuais não é tanto uma questão de qualidade, mas uma questão de quantidade.

Outros dois aspectos observados nesta produção tem relação com o cruzamento constante de limiares. O primeiro diz respeito aos limiares estabelecidos - tanto nos mercados quanto nas disciplinas acadêmicas - entre expressões artísticas: música, arte sonora, artes visuais, teatro e performance. Muitos dos artistas citados tendem a circular com maior facilidade - e retorno financeiro - em ambientes que não o musical, e encontram seu espaço de performance nas galerias de arte e na associação com as artes cênicas e a dança. Isso naturalmente se deve a um engessamento observável no meio musical, tanto na dimensão da música popular urbana quanto da música de concerto, mas também se deve a uma predisposição destes artistas - que em sua maioria iniciam sua atividade na música a transpor estes limiares. Os objetos criados possuem esse aspecto múltiplo e questionador: podem ser somente observados como objetos de arte num espaço como a galeria, vide o exemplo de Smetak ou da exposição Art or Sound? ${ }^{157}$, mas adquirem outra dimensão ao serem executados.

O segundo aspecto é o fato de que em diversos casos os criadores também desempenham o papel de pesquisadores no próprio cenário de que participam. Também aqui os limiares são cruzados e renegociados com frequência, a criação artística viabiliza mas também é viabilizada pela atividade crítica e analítica da pesquisa, sem que haja um vetor estabelecido de direção.

\footnotetext{
${ }^{157}$ Exposição financiada pela Fundação Prada com curadoria de Germano Celant, que explora os aspectos icônicos de instrumentos musicais, assim como as intersecções entre música e artes visuais. Disponível em: < http://www.fondazioneprada.org/project/art-or-sound/?lang=en $>$. Acesso em 27 de maio de 2018.
} 
O compositor, foi se metamorforseando em artista sonoro e performer do seu próprio trabalho, não só na veiculação do seu discurso musical, mas na criação dos seus dispositivos para fazer a sua música ${ }^{158}$.

Esta é uma característica que foi enumerada anteriormente, na seção sobre luteria na música experimental estadunidense e europeia. Vemos aqui também, em alguns exemplos, questões relacionadas com artista viabilizando suas práticas construíndo suas próprias ferramentas e instrumentos, mas também tendo que lidar com as contingências impostas pela necessidade de setups compactos, que possam ser transportados facilmente, e com questões relacionadas com a realidade econômica brasileira, e as formas como o acesso a tecnologias se deu ao longo dos anos. O que se observa é um grande contraste entre o modelo de mercado isolado herdado do período ditatorial e a abertura de mercados que se observa a partir dos anos 1990. No entanto, como será discutido no próximo capítulo, este acesso a tecnologias e a recursos materiais está longe de ser universal.

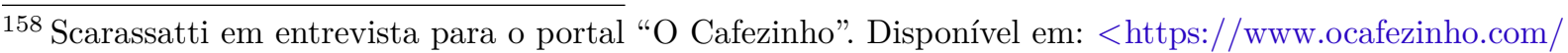
2016/08/03/rumores-do-cotidiano-entrevista-com-o-artista-sonoro-marco-scarassatti/>. Acesso em 23 de fevereiro de 2018. 



\section{Tony da Gatorra}

Neste capítulo apresento uma pesquisa mais extensa sobre a obra de um artista específico, Tony da Gatorra, com ênfase em seu instrumento. A escolha por Tony como objeto de um estudo mais aprofundado se dá por ter percebido que em sua produção observam-se elementos dos aspectos enumerados no capítulo 1, reunindo-se aspectos artesanais, de readymade e de modularidade. Esta escolha também se dá pelo fato de que Tony é um criador relativamente isolado no que diz respeito ao desenvolvimento de seu instrumento e de sua música, não estando ligado diretamente a outros criadores e ambientes de música experimental no Brasil, ao mesmo tempo apresentando uma produção que articula elementos relacionados com práticas artísticas experimentais.

Divido este capítulo em 4 seções, uma biografia com ênfase na carreira de Tony e sua produção; duas seções que focam na materialidade da gatorra, com ênfase em sua carcaça e em seu circuito, respectivamente; e uma seção final de análise onde apresento algumas referências de autores que analisam o trabalho, assim como trechos de depoimentos de pessoas envolvidas, e realizo algumas discussões a respeito destas referências em relação à gatorra e seu criador. No apêndice A disponibilizo algumas informações e referências complementares sobre este artista e sua produção.

\subsection{Biografia}

Tony da Gatorra é o nome artístico de Antônio Carlos Correia de Moura, nascido em Cachoeira do Sul, RS em 3 de agosto de $1951^{1}$. Mudou-se com a família para Esteio, na periferia de Porto Alegre, após a morte da mãe. Estudou dos 8 até os 13 anos no Patronato Agrícola de Taquari, uma instituição de acolhimento e formação para crianças com idade entre 8 e 14 anos:

Quando a minha mãe faleceu eu tinha 3 anos de idade, 4 anos, a gente ficou passando fome, meu pai ganhava salário mínimo, a gente passava muita fome, né? Então meu pai teve uma boa ideia, pelo menos arrumou essas duas bolsas através do Brizola, quando era governador, eu fiquei dos 8 aos 12, eu não tive infância, meu pai nos largou lá pra não ficarmos na rua. ${ }^{2}$

1 Exceto quando indicado, as fontes dos dados biográficos são: $<$ http://pt.wikipedia.org/wiki/Tony_da_ Gatorra>, <https://paulavieira.wordpress.com/2011/08/13/tonydagatorra/>, <http://cenabeatnik. blogspot.com.br/2007/11/tony-da-gatorraassassino.html > e <http://cenabeatnik.blogspot.com.br/ 2008/03/publicidade-atrasada.html>. Acesso em 08 de dezembro de 2016.

2 Tony da Gatorra em entrevista ao programa Matador de Passarinho, do artista carioca Rogério Skylab, exibido originalmente em 23 de julho de 2013. Disponível em: < https://www.youtube.com/ watch? $\mathrm{v}=\mathrm{w} 0 \mathrm{I} 792 \mathrm{vt}-\mathrm{OY}>$. Acesso em 13 de maio de 2018. 
Dos 15 aos 25 anos trabalhou como metalúrgico em Porto Alegre e redondezas, tendo trabalhado por 2 anos em São Paulo neste período. O aprendizado de eletrônica tem início a partir de 1975, quando faz por correspondência um curso técnico em eletrônica no Instituto Universal Brasileiro, e estabelece em seguida uma oficina para conserto de aparelhos eletroeletrônicos em Esteio, onde ainda reside. Tony relata que esteve envolvido com algumas atividades musicais, devido à proximidade com músicos que atuavam em bandas de baile:

Eu não tocava, entende? Eu só armava os aparelhos, plugava os amplis, tudo, foi aí que eu comecei a me ligar na bateria, tive duas baterias usadas, tocava assim em casa, amador, entende? Mas nada profissional, simplesmente porque eu gostava. Por isso que depois, adiante, depois que eu casei, que eu tirei o curso de eletrônica, aí que veio essa ideia de fazer esse instrumento ${ }^{3}$.

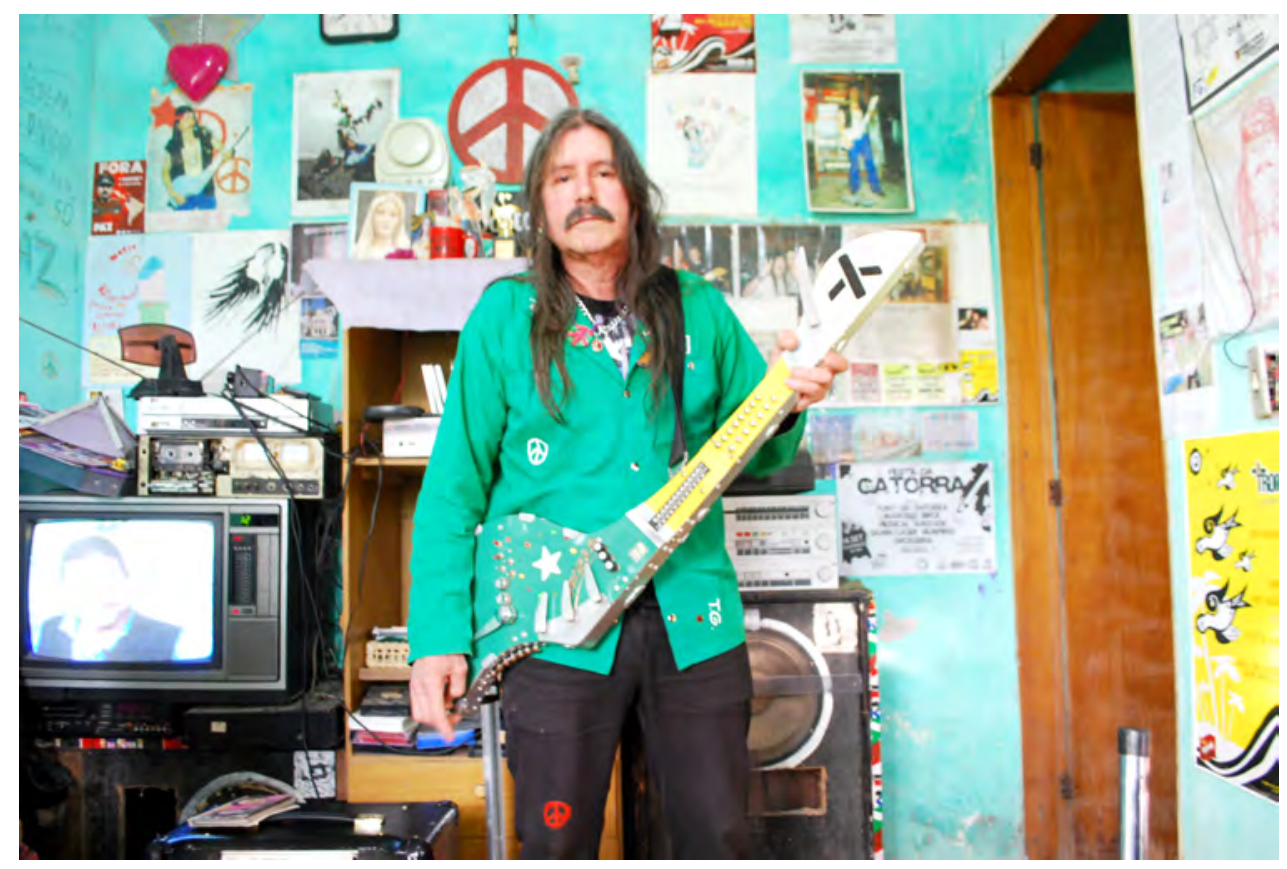

Figura 33 - Tony da Gatorra em sua casa em Esteio, com a gatorra nº12. Foto: Acervo Tony da Gatorra.

O período de desenvolvimento do primeiro protótipo da gatorra está situado entre os anos de 1994 e 1998. Alguns relatos apontam o início deste processo ainda em 1994, outros relatos apontam o ano de 1996 como ano de início da construção ${ }^{4}$, não estando

3 Tony da Gatorra em entrevista ao programa Singulares, da TVE-RS, exibido originalmente em 04 de abril de 2016. Disponível em: < https://www.youtube.com/watch?v=WS9EWO03k1k>. Acesso em 14 de maio de 2018

4 Em entrevista ao portal Dissonância.com, por exemplo, é feita menção ao ano de 1994. Já no relato ao portal Aleatório, o ano citado é 1996. Disponível em: < https://web.archive.org/web/20070110230232/ http://www.dissonancia.com/2006/24-06.htm> e < https://paulavieira.wordpress.com/2011/08/13/ tonydagatorra/>, respectivamente. Acesso em 08 de dezembro de 2016 
claro nas fontes consultadas, ou mesmo em consultas ao próprio Tony, quando o processo teve início de fato, e se é possível fazer uma distinção entre um período de concepção do projeto e um período de construção propriamente dita. Neste período a pesquisa e o desenvolvimento do primeiro protótipo da gatorra tiveram uma influência considerável na vida pessoal de Tony, no tocante ao investimento de tempo e de recursos financeiros ${ }^{5}$. Apesar das informações conflitantes, o ano de 1998 é no mais das vezes mencionado como sendo o ano de conclusão deste primeiro protótipo, que passou a ser conhecido como gatorra $n^{\circ} 1$, e das primeiras gravações feitas por Tony e lançadas na forma de um CD de demonstração, intitulado Paz e Amor.

Segundo o próprio Tony, há uma relação entre a escolha do tipo de circuito utilizado na gatorra, e um interesse anterior por instrumentos de percussão: "determinados circuitos que produziam certos timbres [percussivos] me chamaram a atenção, aí eu comecei a ler, estudar, e inventei de pegar e botar na prática"6

Já o processo de composição e criação musical surge como uma novidade na vida de Tony, com certa de 40 anos na época: "Não sabia nada de música, foi difícil de início"7, mas é balizada pela perspectiva de fazer música de protesto. Apresentações na Esquina Democrática, em Porto Alegre ${ }^{8}$.

"As minhas músicas são simplesmente de protesto. Eu não faço música nem para ganhar dinheiro, nem para dançar ou se alegrar muito, entende? Minhas músicas não tem nada a ver com diversão. Então eu faço minhas músicas sentindo na pele o que eu passei e vivenciando o que os outros estão passando hoje no Brasil, entende?"9

Sobre a escolha do nome, Sérgio Pinto (2012, p. 270) chama a atenção para a sintaxe do nome Tony da Gatorra, semelhante à de outros artistas brasileiros também associados ao seus instrumentos como Paulinho da Viola, Nelson Cavaquinho e Jackson do Pandeiro. Esta escolha inverte uma constante no cenário de criação de instrumentos eletroeletrônicos da primeira metade do século XX, observada por Raaijmakers (2000, p. 19), em que os inventores batizam seus instrumentos a partir de alguma associação ou aglutinação com seus nomes: Ondes Martenot, o Trautonium de Friedrich Trautwein, o Theremin de Lev Thermen, e o Hellertion de Bruno Helberger, entre outros.

5 Dois eventos associados a este processo são comumente mencionados por Tony: A venda de uma motocicleta para financiar sua pesquisa, e ter sido abandonado por sua companheira na época em virtude do seu envolvimento com o projeto. Disponível em:<https://web.archive.org/web/20070110230232/http: //www.dissonancia.com/2006/24-06.htm>. Acesso em 08 de Dezembro de 2016.

6 Tony da Gatorra em entrevista ao programa Matador de Passarinho, do artista carioca Rogério Skylab. Disponível em: < https://www.youtube.com/watch?v=w0I792vt-OY>. Acesso em 13 de maio de 2018.

7 Disponível em: <http://cenabeatnik.blogspot.com.br/2008/03/publicidade-atrasada.html>. Acesso em 08 de dezembro de 2016.

8 (CONTER, 2016, p. 145).

9 Disponível em:<https://web.archive.org/web/20070110230232/http://www.dissonancia.com/2006/ 


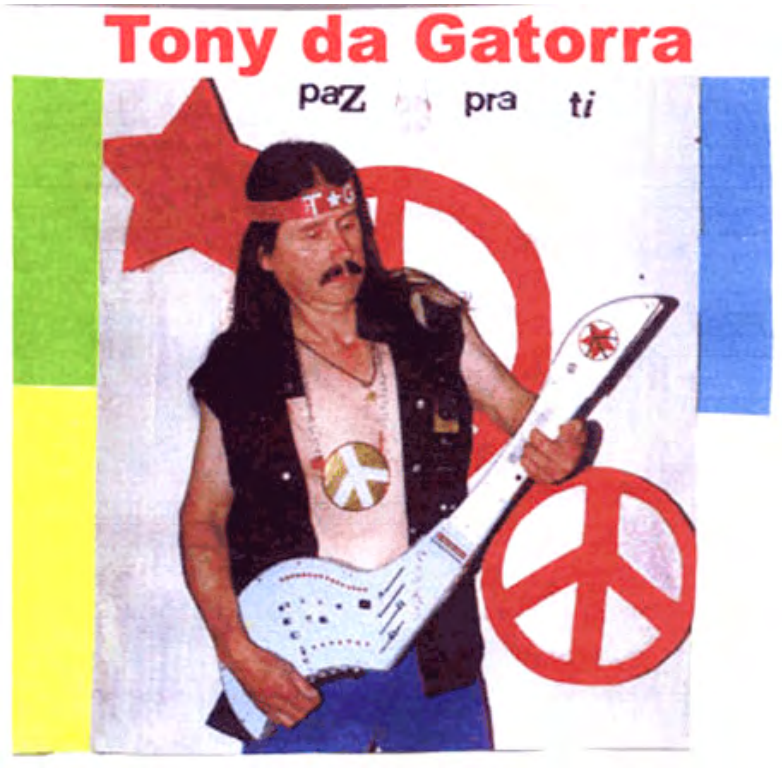

Figura 34 - Capa de Paz pra ti, lançado por volta de 1998 com as primeiras gravações de Tony da Gatorra.

Após a gravação do seu primeiro cd de demonstração, Tony começa a fazer apresentações em praças públicas de Esteio e Porto Alegre ${ }^{10}$, e procura os veículos convencionais de mídia para divulgar suas músicas, como a rádio Ipanema de Porto Alegre, conhecida por abrir espaços na programação para os artistas locais:

Eu conheci o Tony quando ele levou o material pra gente lá na Ipanema [...] A gente tinha um programa na tv que se chamava College na TV, $[\ldots]$ ele ia pro programa sempre em feriados porque o trem não era tão movimentado e pra ele ficava tranquilo levar a gatorra, a caixa de som [...] como o programa era ao vivo, sempre em feriados o Tony dava um jeito de aparecer lá, a gente já sabia que ele ia aparecer, ele não tinha telefone celular, não tinha telefone em casa, alguns amigos às vezes ligavam avisando que ele ia e tal, mas era meio esperado, então a gente sempre deixava um espaço na pauta da TV pra ele aparecer ${ }^{11}$.

A parceria com Eduardo Santos, as participações no programa College na TV e também as apresentações na rua geraram muita visibilidade em Porto Alegre e no cenário musical alternativo Rio Grande do Sul. Em 25 de setembro de 1999 Tony se apresenta em um espaço de shows pela primeira vez, na quinta edição do Bailão do CardosOnline, realizado na casa Garagem Hermética, em Porto Alegre ${ }^{12}$ pelos colaboradores do fanzine eletrônico CardosOnline. Tony constrói a segunda gatorra entre o final de 2000 e o início

24-06.htm>. Acesso em 08 de Dezembro de 2016.

10 (CONTER, 2016, p. 145)

11 Eduardo Santos, informação pessoal em 10 de março de 2018

12 Disponível em:<http://cabrapreta.org/COL/col_bailao.html>. Acesso em 20 de maio de 2018. 


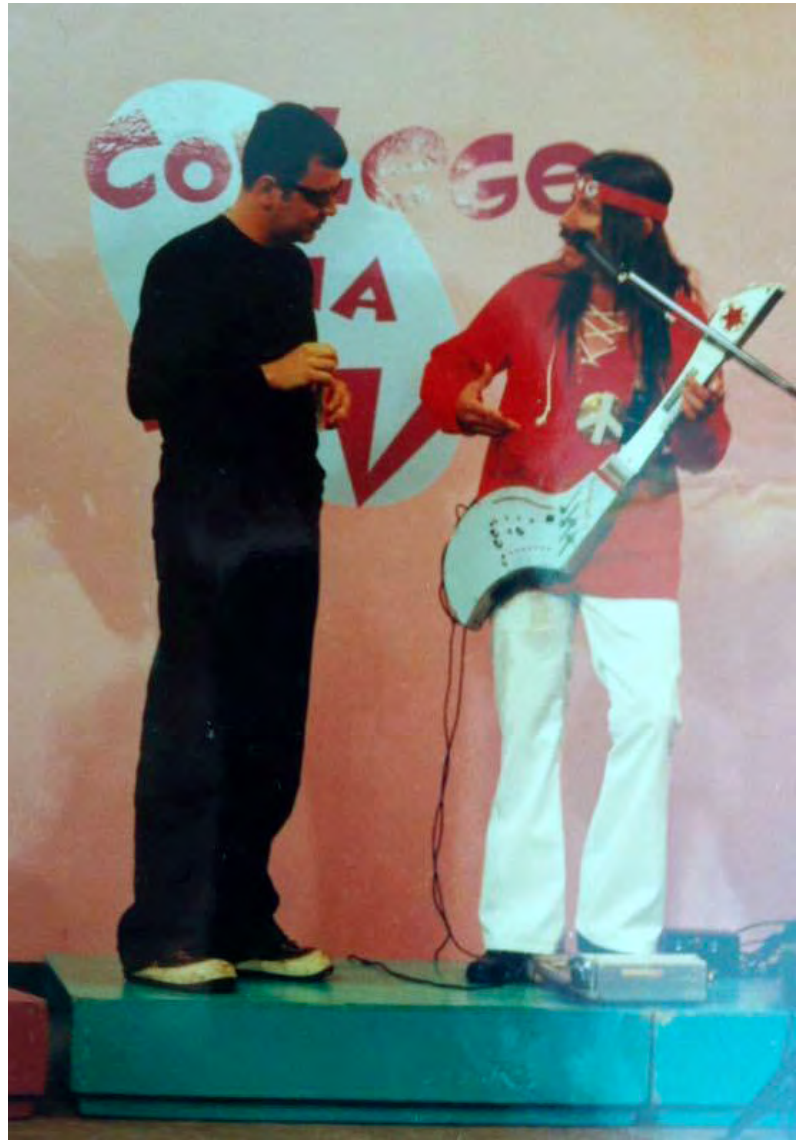

Figura 35 - Eduardo Santos e Tony da Gatorra no programa College na TV, em 1998. Foto: Acervo Eduardo Santos.

de $2001^{13}$, inicialmente buscando um instrumento mais leve, com alguns aprimoramentos no circuito. Esta gatorra, no entanto, será vendida alguns anos depois. No período entre 1998 e 2004 Tony também grava mais músicas, algumas delas em parceria com alguns artistas do cenário musical independente de Porto Alegre:

Eu acho que quem foi importante na carreira dele aqui, acho que o Miranda deu uma força quando o Tony tentou conectar as coisas em São Paulo, o Miranda que já morava aí indicou ele pra algumas pessoas e tal, a galera da Comunidade Nin-Jitsu, o Fred e o Chernobyl, também fizeram coisas com o Tony, o Carlinhos da Bidê ou Balde, a galera citava muito ele e tentava dar espaço pra ele, enfim, de maneira geral acho que é um cara muito querido por todo mundo aqui ${ }^{14}$.

Este segundo CD recebe o nome de "Só Protesto", que também será usado em seu próximo lançamento. Tony vai a São Paulo como artista pela primeira vez em 2004 para se

\footnotetext{
13 De acordo com entrevista no programa College na TV, em janeiro de 2001. Disponível em: <https: //www.youtube.com/watch?v=1b5ncg97FG0>. Acesso em 5 de maio de 2018.

14 Eduardo Santos, informação pessoal em 10 de março de 2018
} 
apresentar no programa do apresentador Raul Gil. Nesta viagem, Tony entra em contato com o produtor Carlos Eduardo Miranda a partir da indicação de Eduardo Santos:

Um dia ele veio pra São Paulo pra gravar alguma coisa no Raul Gil [...] e deram pra ele o meu telefone [...] Aí tou eu na Trama, toca o telefone: "Ô Miranda, aqui é Tony da Gatorra", aí eu "Opa, Tony, beleza?", e ele: "Bah, tou apavorado aqui, tou sem dinheiro tou num hotel aqui em frente à rodoviária, parece uma casa fantasma, só tem uns marginais aqui, não sei o que fazer" [...] Aí eu falei com o Dago ${ }^{15}$.

Dago Donato - jornalista, DJ, e agitador cultural paulistano - também se recorda do episódio:

Um dia o Miranda me fala: o Tony vai te ligar [... mas eu tava no trabalho e não conseguia sair pra ajudar. Liguei pro Gui, que tinha a Peligro na época e marcava os shows na minha loja, contando [...] e ele [foi até o] hotel que em que o Tony estava hospedado, comprou todos os discos que ele tinha trazido, botou ele no ônibus de volta pra Esteio e prometeu trazê-lo de volta pra uma série de shows. Foi o que rolou no ano seguinte ${ }^{16}$.

Guilherme Barrella na época estava envolvido com um selo e distribuidora de CD's independentes, a Peligro, e faz referência ao episódio em um informativo do selo de setembro de 2004:

E pra finalizar, a melhor descoberta dos últimos tempos: Tony da Gatorra. Não tenho palavras para descrevê-lo. Só sei que ele veio até São Paulo, disposto a fazer um show na Generics, e ao se deparar com a grande metrópole, surtou e voltou pra casa. Mas ele garante que volta até o fim do ano, agora que ele já sabe o que encontrar. Tony, a gente te espera. Você é um gênio ${ }^{17}$.

A partir deste contato, inicia-se um período na carreira de Tony de parcerias com Donato, Barrella e também com os irmãos Eduardo e Bruno Ramos Pereira. Uma página com o material gravado de Tony é criada no portal Trama Virtual, ainda em fase de testes, o que colaborou em grande medida para a divulgação do seu trabalho fora do Rio

15 Carlos Eduardo Miranda, informação pessoal em 7 de março de 2018

16 Dago Donato, informação pessoal em 9 de março de 2018.

17 Disponível em: <https://web.archive.org/web/20040928061039/http://www.peligro.com.br:80/> 


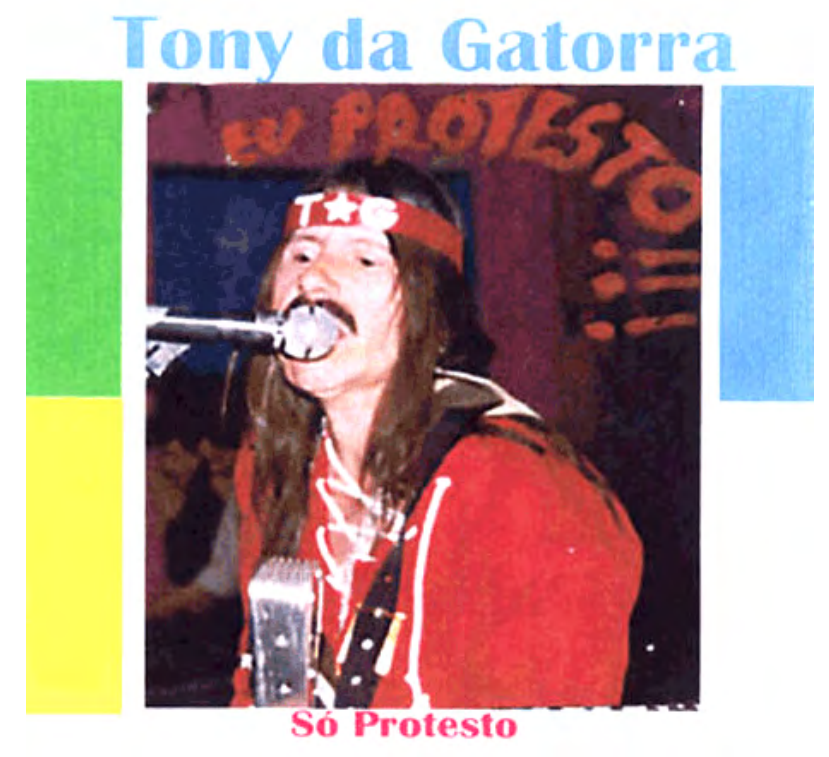

Figura 36 - Capa da versão original do disco Só Protesto, distribuído pela Peligro em 2004.

Grande do Sul e de São Paulo ${ }^{18}$. Em março de 2005 Tony retorna a São Paulo para tocar no espaço Milo Garage ${ }^{19}$, a primeira de uma série de apresentações neste espaço.

Barrella relança as primeiras gravações de Tony em CD com o título de "Só Protesto" em Maio de $2005^{20}$. É também através da associação com a Peligro que Tony é convidado pela primeira vez para tocar no SESC Pompéia, episódio que deu origem à música "Meu nome é Tony" após ter sua participação em um festival cancelada por falta de documentação junto à Ordem dos Músicos do Brasil:

Por volta de 2003, 2004, eu fazia parte do núcleo de música e artes cênicas do Sesc Pompeia, responsável pela programação dessas linguagens. Neste período, além do contato direto com artistas e produtores, eu acompanhava a programação musical da cidade e seguia algumas listas e boletins. Um desses boletins era da Peligro Discos, do Guilherme Barrella. Foi em um desses boletins da Peligro que eu fiquei sabendo sobre o trabalho do Tony da Gatorra. [...] Esse festival aconteceu em maio de 2005, se não me engano [...] A participação do Tony acabou sendo cancelada, por falta de documentação da OMB - esse foi o show para o qual ele foi convidado, como diz em Meu Nome é Tony -, muito mais por falta de habilidade da produção ${ }^{21}$.

18 O portal Trama Virtual operou entre 2002 e 2013 e foi amplamente utilizado por diversos artistas independentes brasileiros como plataforma de lançamento e divulgação de seus trabalhos. Disponível em: <http://gizmodo.uol.com.br/tramavirtual-encerrara-atividades-em-31-de-marco/ .Acessoem7demarçode2018. $>$

19 Disponível em: <https://web.archive.org/web/20050306041422/http://www.peligro.com.br:80/>. Acesso em 7 de março de 2018.

20 Guilherme Barrella, comunicação pessoal via Facebook Messenger em 6 de abril de 2017.

${ }^{21}$ Sérgio Pinto, informação pessoal em 15 de março de 2017. 
É nesta período que tem início a produção de gatorras em série, a partir das primeiras encomendas feitas por Guilherme Barrella, Bruno Ramos Pereira e Luísa Lovefoxxx, respectivas às gatorras $\mathrm{n}^{\circ} 3,4$ e 5. Também nesta época Tony começa a escrever para um blog no endereço <http://tonydagatorra.blogspot.com.br>, que será mantido até janeiro de 2012, data da última postagem ${ }^{22}$. Sua carreira passa a ser gerida pelos irmãos Ramos Pereira, que também se comprometem a lançar um disco de Tony por seu selo Slag Records. Boa parte do material para este álbum é gravado em dezembro de 2005, quando também são feitos alguns registros em vídeo por Binho Miranda ${ }^{23}$ :

Neste processo de gravar o documentário, eu fui pra Esteio [...] Antes de ir já tinha me oferecido pra comprar a gatorra $\mathrm{n}^{\circ} 2$, o instrumento que a gente chama de Gatorra Baixo [...] comprei a gatorra pagando em várias parcelas, mandando dinheiro escondido por envelope, por banco postal, depositando na conta de amigos do Tony. Uma doideira ${ }^{24}$.

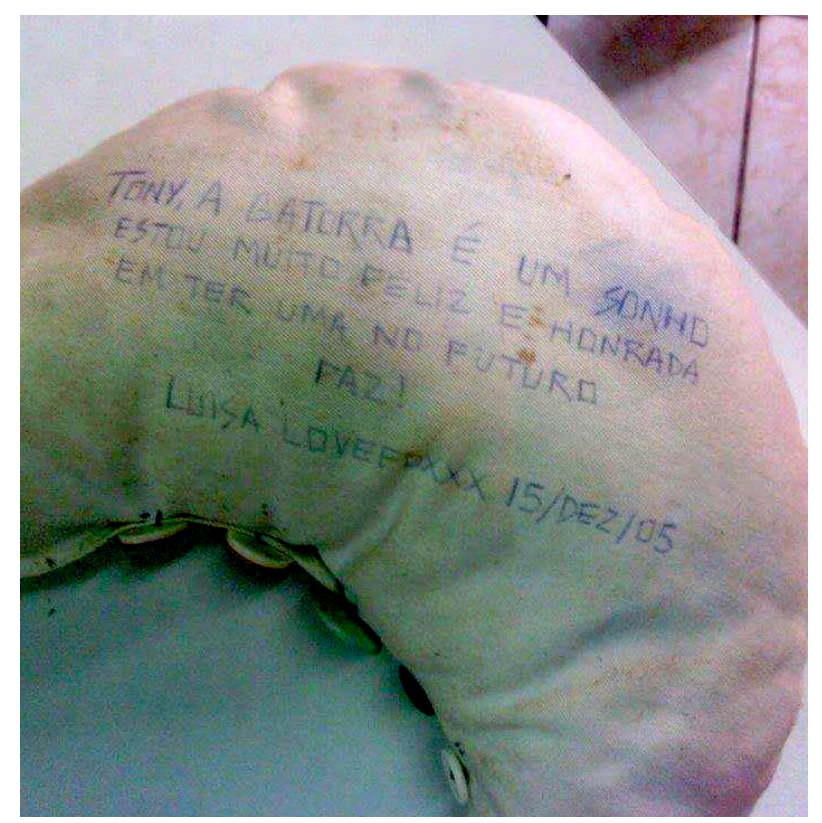

Figura 37 - A gatorra de pano, feita por Luísa Lovefoxxx para Tony. Foto: Acervo Tony da Gatorra.

O álbum resultante destas sessões, Novos Pensamentos, só é lançado em 2008, devido a alguns atrasos em seu processo de produção e também a questões envolvendo o empresário Eduardo Ramos Pereira e o grupo Cansei de Ser Sexy, da qual Luísa Lovefoxxx

22 Por muito tempo a dinâmica de publicação do blog de Tony consistiu no envio de cartas de Tony para Guilherme Barrella, que compartilhava o conteúdo das cartas no blog.

23 Disponível em: <http://tonydagatorra.blogspot.com.br/2005/12/13122005.html>. Acesso em 20 de maio de 2018.

24 Binho Miranda, informação pessoal em 24 de maio de 2018. 
faz parte ${ }^{25}$. O álbum foi editado e mixado por mim no segundo semestre de 2007, sem uma participação direta dos demais envolvidos.

De qualquer modo, o período entre 2005 e 2010 é um período de bastante visibilidade para Tony nos veículos de comunicação tradicionais, e também o período em que Tony realiza algumas apresentações fora do Brasil, tendo se apresentado na Europa e no Reino Unido em 2007 e $2010^{26}$.

Neste período também são feitas as gatorras de número 6 a 12. A gatorra $n^{\circ} 6$ é feita sob encomenda para Sérgio Pinto:

Nesse período em que conheci o trabalho do Tony, muito se falava no "efeito colateral do sistema" que representava o uso imprevisto da tecnologia digital por parte de comunidades marginalizadas - funk carioca, tecno-brega paraense, reggaeton latino, etc. Para mim, a gatorra fazia parte um pouco desse universo, embora Tony não trabalhasse dentro desses cânones. Mas o fato do instrumento ser, ao mesmo tempo, de baixa tecnologia e conter conceitos das vanguardas do princípio do século XX como as máquinas de fazer ruídos de Russolo ou dos futuristas russos - é o que mais me fascina ${ }^{27}$.

A gatorra $n^{\circ} 7$ é produzida neste período para o músico escocês Nick McCarthy, integrante do grupo Franz Ferdinand, nas cores verde e amarela para representar o Brasil. Esta gatorra eventualmente é repassada por McCarthy a Graeme Ronald: "Nick conhecia a minha música e meus interesses musicais - instrumentos estranhos, brinquedos, instrumentação não-convencional - e achou que eu poderia usar a Gatorra mais do que ele" ${ }^{28}$. Muitas narrativas sobre a carreira de Tony chamam atenção para o fato de que Tony construiu instrumentos para Lovefoxxx e McCarthy, mas não há muitos registros destes artistas comentando ou utilizando a gatorra propriamente.

Boa parte da visibilidade de Tony no exterior deve-se à sua associação com o músico galês Gruff Rhys, integrante da banda Super Furry Animals, com quem tocou em duo como parte da programação do festival Troca Brahma. O festival, realizado em 2007, consistiu em uma série de eventos promovendo o encontro de artistas brasileiros e britânicos com apresentações no Brasil e no Reino Unido ${ }^{29}$. A partir das gravações feitas

25 Disponível em: <http://g1.globo.com/Noticias/Musica/0,,MUL110220-7085,00-CANSEI+DE+SER+ $\mathrm{SEXY}+\mathrm{DIZ}+\mathrm{QUE}+\mathrm{VAI}+\mathrm{A}+\mathrm{JUSTICA}+\mathrm{CONTRA}+\mathrm{EXEMPRESARIO} \cdot \mathrm{html}>$. Acesso em 20 de maio de 2018.

26 Disponível em: <http://tonydagatorra.blogspot.com.br/2007/05/agenda-tony-da-gatorra-junhojulho-0306. html>, <http://tonydagatorra.blogspot.com.br/2010/08/23082010.html > e < http://drownedinsound. com/news/4139539-gruff-rhys-and-tony-da-gatorra-announce-album-and-live-dates $>$. Acesso em 08 de dezembro de 2016.

27 Sérgio Pinto, informação pessoal por e-mail em 15 de março de 2017

28 Graeme Ronald, informação pessoal por e-mail em 14 de novembro de 2017

29 Disponível em: <http://urbanistas.com.br/sp/2007/06/03/ultimo-dia-do-festival-troca-brahma/>. Acesso em 15 de maio de 2018. 


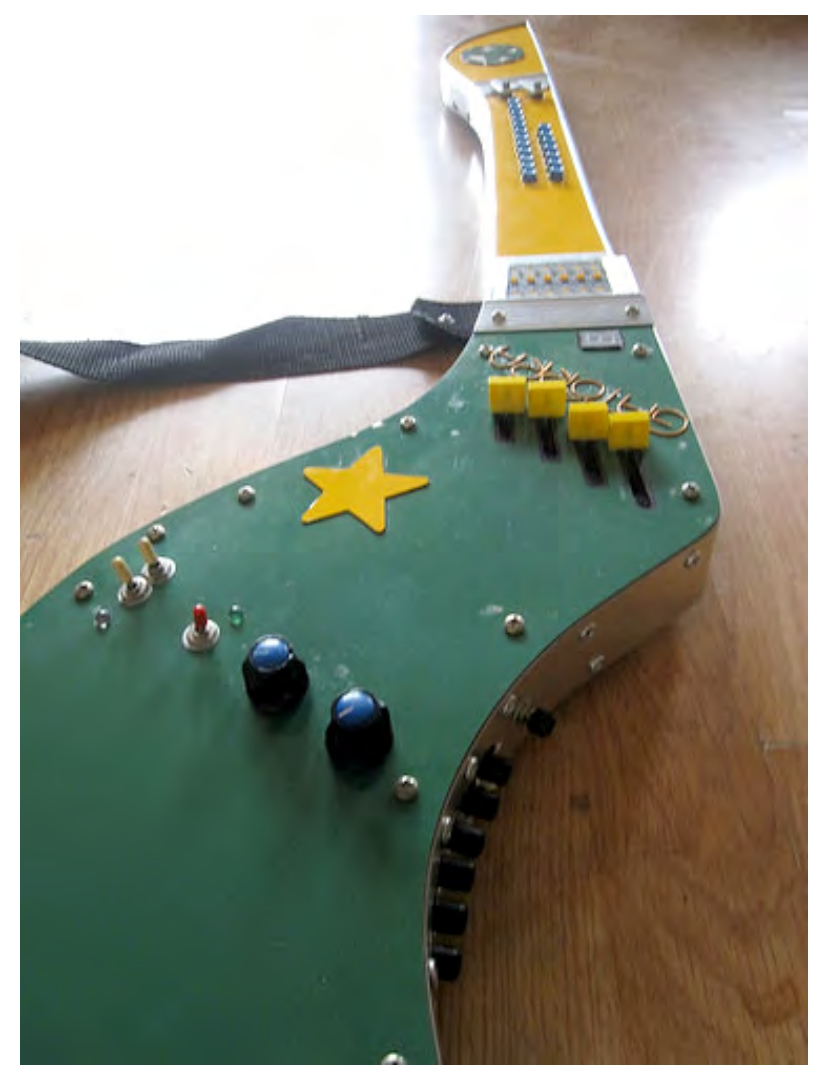

Figura 38 - Gatorra nº7, feita para Nick McCarthy. Foto: Graeme Ronald.

nos ensaios para as apresentações do festival, Rhys editou, compilou e produziu um disco creditado aos dois artistas, The Terror of Cosmic Loneliness, lançado no Reino Unido pelo selo Turnstile Music em $2010^{30}$. Tony também aparece brevemente no filme Separado!, dirigido por Rhys juntamente com Dylan Goch, que narra a peregrinação de Rhys à América do Sul em busca de informações sobre pessoas de sua família, e em especial o artista chileno-galês René Griffiths ${ }^{31}$.

Desde 2008 Tony também desenvolve uma parceria com o músico, compositor e professor universitário Marcelo Birck, que faz algumas apresentações junto a Tony, e também organiza palestras e apresentações de Tony em Universidades. Em 2015 Birck encomenda a gatorra $n^{\circ} 21$.

A partir de 2011 a visibilidade carreira de Tony torna-se menos ativa, tanto devido a fatores econômicos no Brasil e no exterior, mas também devido à falta de um gerenciamento regular. Binho Miranda, que desde 2005 vinha realizando registros em vídeo de Tony com a intenção de produzir um documentário a seu respeito desempenha em alguns momentos

$\overline{30} \mathrm{O}$ disco pode ser ouvido na íntegra em < https://www.youtube.com/playlist?list=PLg9IaBA_ buO1dyQHkrq5B8x9cBydtSeeM>. Acesso em 14 de maio de 2018.

31 O trailer de Separado! pode ser visto em: <https://www.youtube.com/watch?time_continue $=15 \&$ $\mathrm{v}=\mathrm{r} 2 \mathrm{IfD}-6 \mathrm{iS} 3 \mathrm{Y}>$. Tony, Rhys e Griffiths se apresentaram juntos na estréia do documentário em . Acesso em 19 de maio de 2018. 
a função de empresário ${ }^{32}$. Sobre a frequência de shows no Rio Grande do Sul neste período, Tony afirma: "Ninguém me procura lá no Rio Grande do Sul, eles não gostam do meu estilo, lá é Fandango e Vaneirão, aquela gauchada ela não gosta de rock, o roqueiro lá morre de fome" 33

Em 2013 e 2015, colaborei com a realização de palestras de Tony para alunos e grupos de estudo na USP e na Universidade Anhembi Morumbi, assim como na realização de shows nos espaços Ibrasotope e Casa do Mancha ${ }^{34}$. Nos shows de 2015 me apresentei juntamente com Tony tocando a gatorra $\mathrm{n}^{\circ} 19$, encomendada por mim. Neste período Tony inicia uma parceria com o músico gaúcho Tainam Dias, que ajuda a viabilizar a produção e lançamento dos discos "Gomorra" e "O som da gatorra", de 2016 e 2018, respectivamente. Em 2016, me apresentei novamente junto com Tony e Tainam nos festivais Grito da Terra, em Concórdia-SC, e no ENCUN, em Porto Alegre, e em 2018 colaborei para a realização de uma palestra de Tony nas Faculdades Integradas Barros Melo e uma apresentação no espaço Edifício Texas, em Olinda e Recife-PE, respectivamente ${ }^{35}$.

\subsection{Carcaça}

O circuito eletrônico é montado em uma carcaça que emula o formato de cordofones como o violão e o alaúde, dividido em duas seções que podemos denominar de corpo e braço. A seção do corpo possui um formato de lua minguante - ou de foice, segundo $\operatorname{alguns}^{36}$ - possuindo uma concavidade na parte inferior onde é instalada uma botoeira. No tampo do corpo normalmente são instalados alguns controles correspondentes a alguns dos sons, mas a quantidade e o formato destes controles é variável de acordo com o modelo. Normalmente nesta parte do instrumento é colocado um indicador numérico feito com LED, usado para indicar o número de série do instrumento.

A primeira gatorra ela foi feita simplesmente de sucata, isso aqui é um protótipo, as novas agora tem mais aperfeiçoamento no acabamento delas. Essa aqui foi feita mais de sucata de peça de TV e rádio, né? [...] a carcaça dela é de madeira, eu fiz uma escavação pra colocar o circuito eletrônico nela. ${ }^{37}$.

32 O documentário ainda não foi terminado, mas um trailer pode ser visto em < https://vimeo.com/ $13232951>$. Acesso em 19 de maio de 2018.

33 Tony da Gatorra em entrevista ao programa Matador de Passarinho, do artista carioca Rogério Skylab. Disponível em: < https://www.youtube.com/watch?v=w0I792vt-OY>. Acesso em 13 de maio de 2018 .

34 Os encontros aconteceram nos dias 23 de agosto de 2013, e entre 18 e 21 de março de 2015.

35 Em 17 de maio de 2018.

36 Disponível em: < http://drownedinsound.com/news/4147862-planet-gear--remember-remembers-lost-and-found-sour Acesso em 20 de maio de 2018.

37 Depoimento a Giuliano Obici em 18 de setembro de 2011, no evento \#3DIS Experimental. 


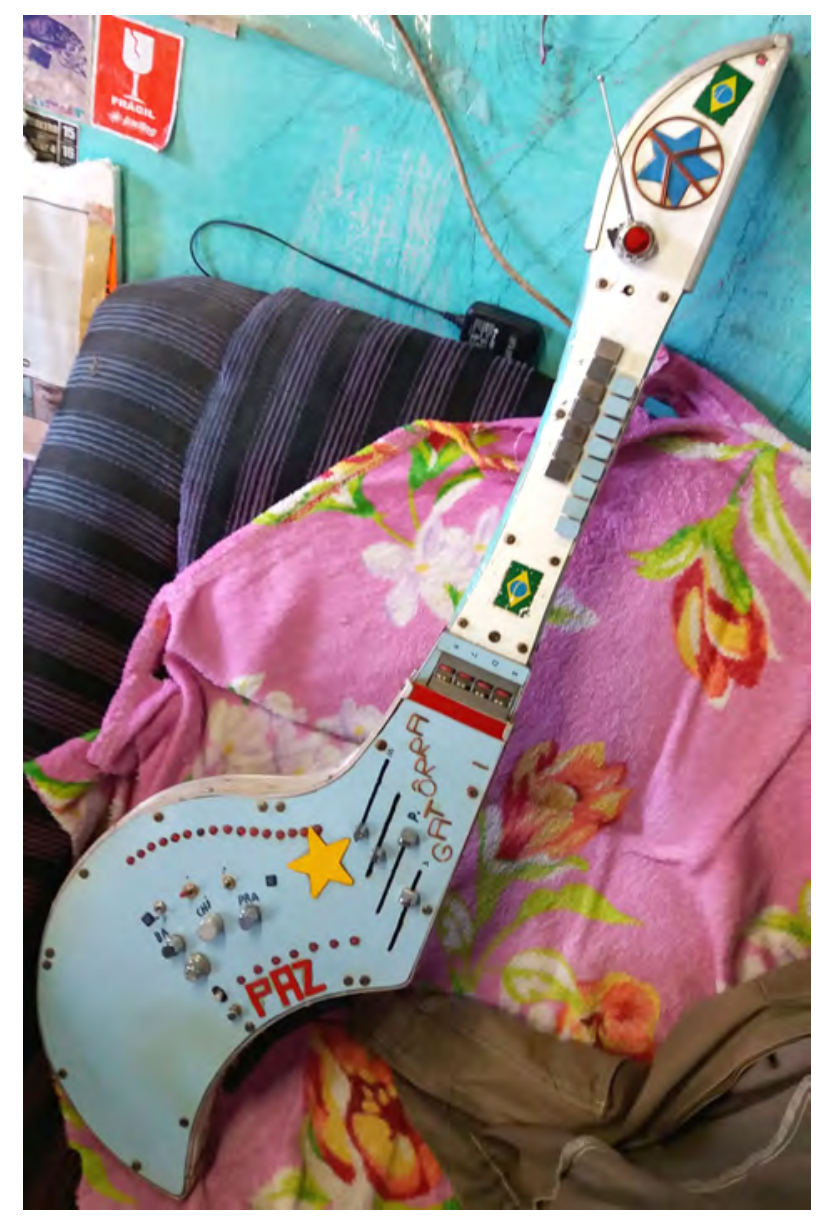

Figura 39 - Gatorra nº 1 . Foto do autor.

Eu tinha muita sucata de televisão, então os componentes que eu precisava estavam ali, né? Que era transistor, capacitor, diodos, silicones, eu tirei um pouco ali da televisão. Outra parte das teclas, por exemplo, tirei um pouco de videocassete. ${ }^{38}$

A botoeira do corpo inicialmente era feita a partir de teclas reaproveitadas de máquinas de escrever elétricas, teclados antigos de computador e videocassetes, tendo sido substituídas por interruptores sem trava, para os quais Tony passou a confeccionar botões de alumínio, de modo semelhante aos botões na botoeira do braço. Em alguns casos, como a gatorra $\mathrm{n}^{\circ} 2$ e a $\mathrm{n}^{\circ} 5$, as teclas foram selecionadas para formar palavras na botoeira do corpo:

Em uma das gatorras que construiu, teve o cuidado de colocar todas as letras do nome da cantora Lovefoxxx [...] Para a minha, ele tão teve o mesmo cuidado,

38 Tony da Gatorra em entrevista ao programa Singulares, da TVE-RS, exibido originalmente em 04 de abril de 2016. Disponível em: <https://www.youtube.com/watch?v=WS9EWO03k1k>. Acesso em 14 de maio de 2018 
colocou as teclas $* /+\# \& 6 \mathrm{~K}$, talvez por serem as únicas disponíveis enquanto a construía ${ }^{39}$.

No braço normalmente há uma seção com duas botoeiras, uma das quais é redundante com a botoeira do corpo, a outra dedicada a sons diferentes. Também é comum encontrar-se no braço uma seção de afinação para alguns dos sons. Gatorras mais antigas tendem a ter mais opções de afinação, com este controle sendo feito a partir de um sintonizador de canais de uma televisão reaproveitado. Na parte do braço correspondente ao que seria a mão de um instrumento tradicional, normalmente há uma ou mais alavancas de controle que podem ou não estar associadas a sons presentes nas botoeiras. Sérgio Pinto (2012, p. 270) chama a atenção para a semelhança entre a botoeira da gatorra e a botoeira de uma sanfona, uma característica também observada por alguns participantes e por pessoas do público em palestras ou shows de Tony ${ }^{40}$. Além das botoeiras na carcaça da gatorra, um plug do tipo RCA é colocado no tampo traseiro do corpo do instrumento, ao qual conecta-se um pedal para acionar o som correspondente ao bumbo de uma bateria convencional.

Uma mudança no design da gatorra ocorre após a construção do instrumento de número 13, a "última gatorra artesanal" 41 , feita em 2008 sob encomenda. Na gatorra n¹4, também apelidada de Gatorra Digital, é usado um design transicional, com algumas características que vão se manter nos modelos seguintes. A primeira é que os tampos frontal e traseiro passam a ser feitos com sobras de chapas de alumínio, plástico, acrílico, e em alguns casos partes do tampo recebem um revestimento adicional de $\mathrm{EVA}^{42}$. Em partes menores do tampo de alguns instrumentos ainda é utilizada a fórmica, mas este material vai sendo abandonado gradualmente. Outra característica das gatorras a partir da $\mathrm{n}^{\circ} 14$ é uma redução na quantidade de sons sintonizáveis, principalmente devido à escassez de sintonizadores de TV utilizados para controlar uma quantidade maior de sons.

Entre a fabricação das gatorras $\mathrm{n}^{\circ} 13$ e nº 14 há um hiato de aproximadamente 3 anos, o que certamente contribui para a mudança em seu design. Neste hiato começam a

39 (PINTO, 2012, p. 271)

40 Ao longo da elaboração deste trabalho me foram apontadas as semelhanças entre o formato da gatorra e o formato e modo de execução da Drumitar, instrumento tocado por Roy "Futureman" Wooten, percussionista do grupo Béla Fleck \& The Flecktones. Além da forma de vestir e executar o instrumento, com sons percussivos tocados tanto no corpo quanto no braço, e do aspecto lo- $f$ do visual do instrumento, observo poucas semelhanças dado que a Drumitar trata-se de um controlador MIDI Synthaxe com poucas adaptações, conectado a módulos com amostras de sons percussivos, não possuindo geradores de som internos. Estimo que o visual fora do comum utilizado tanto por Wooten quanto por Tony da Gatorra também sirva de estímulo para estas aproximações. Informações sobre a Drumitar e outros controles semelhantes disponíveis em: < https://en.wikipedia.org/wiki/Zendrum>. Acesso em 21 de maio de 2018.

41 Disponível em: <http://tonydagatorra.blogspot.com.br/2008/12/19122008.html>. Acesso em 08 de dezembro de 2016

42 Sigla para o polímero Acetato de Vinil Etileno, espuma sintética com diversas aplicações. Disponível em: <https://en.wikipedia.org/wiki/Ethylene-vinyl_acetate>. Acesso em 20 de maio de 2018. 
ser produzidos dois novos instrumentos, a Minigatorra em $2010^{43}$ e o Batucador em $2011^{44}$. A minigatorra é uma versão reduzida do instrumento desenvolvida para ter um preço mais acessível, e também para ser utilizada por crianças, e no período de 2010 e 2011 é comum ver o próprio Tony utilizando minigatorras em suas apresentações. Já o batucador possui um formato diferente, sendo montado normalmente em uma caixa retangular, e posteriormente em caixas de montagem convencionais. Ambos oferecem uma número reduzido de sons, entre 5 e 8 na minigatorra e entre 3 e 5 nos batucadores.

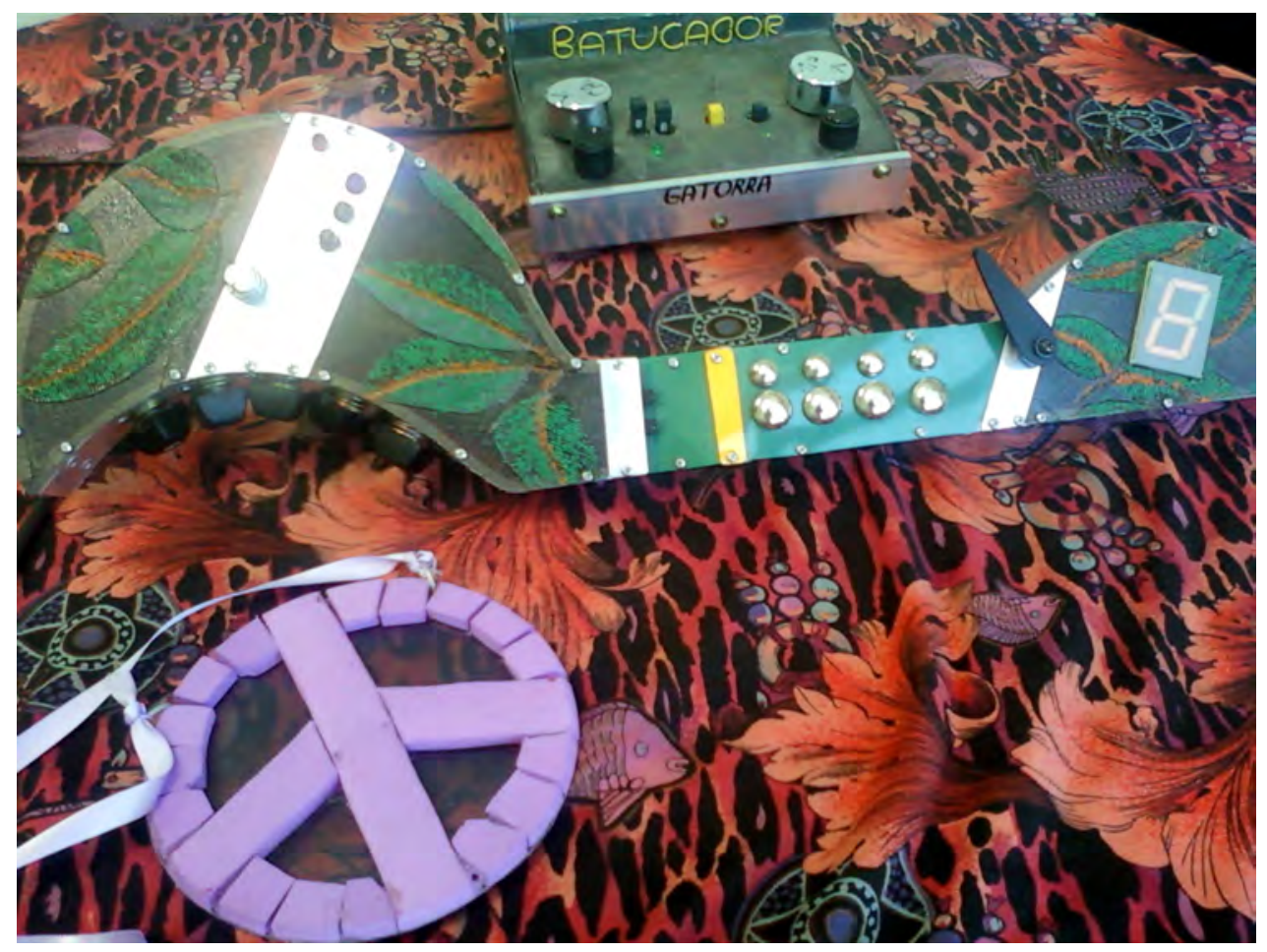

Figura 40 - Minigatorra $n^{\circ} 6$ e Batucador $n^{\circ} 1$. Foto: Acervo Tony da Gatorra.

Na época em que é feita a gatorra nº 14 também são feitas as primeira tentativas de utilizar um sistema de transmissão sem fio, mas até o presente momento não foi encontrada uma solução permanente que possa ser embutida nos instrumentos. Na gatorra utilizada por Tony no período de conclusão deste trabalho, a solução utilizada é a adaptação do circuito de um microfone sem fio, e para desligar a gatorra da fonte foi adaptada uma bateria de computador portátil.

Em parte a mudança no design também está associada a um período em que Tony busca parceiros para viabilizar uma produção em série da gatorra ${ }^{45}$, incluindo-se aí uma tentativa de estabelecer uma parceria com o hackerspace Garoa Hacker Clube. Ao mesmo

43 Disponível em: <http://tonydagatorra.blogspot.com.br/2010/11/08112010.html>. Acesso em 22 de maio de 2018.

44 Disponível em: <http://tonydagatorra.blogspot.com.br/2011/10/24102011_24.html>. Acesso em 22 de maio de 2018.

45 Disponível em: <http://tonydagatorra.blogspot.com.br/2008/12/10122008.html>. Acesso em 08 de dezembro de 2016 


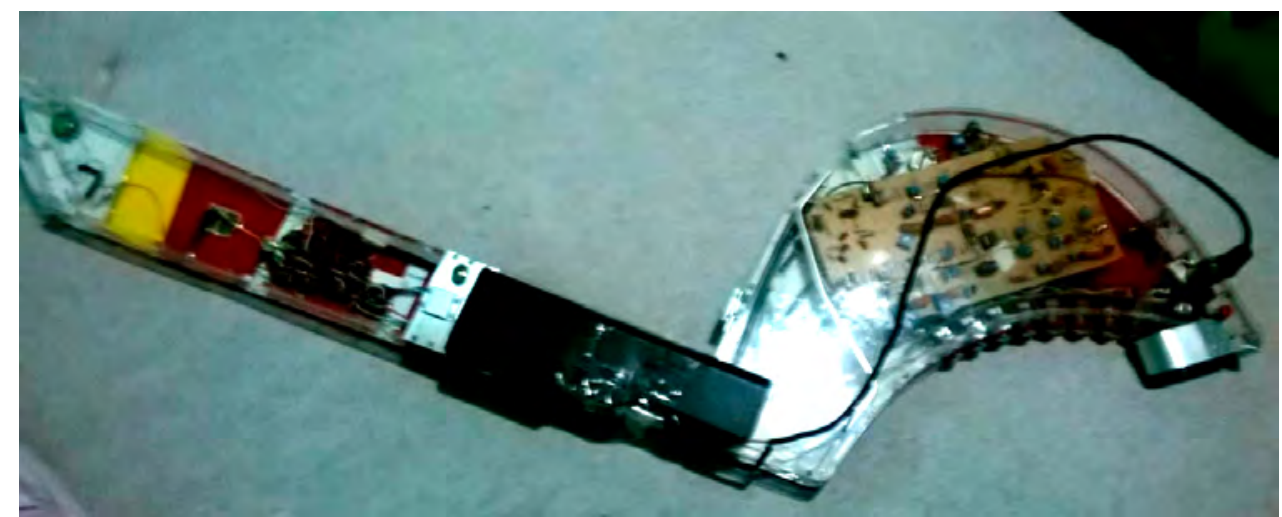

Figura 41 - Gatorra $\mathrm{n}^{\circ} 26$ com bateria de laptop acoplada. Na direita da foto vê-se uma adaptação para encaixar o corpo do microfone sem fio. Foto: Acervo Tony da Gatorra.

tempo que busca este tipo de parceria, Tony demonstra uma grande preocupação com a possibilidade de suas criações serem copiadas e produzidas sem que receba os devidos créditos e dividendos:

Então, eu posso botar diagrama, claro, que eu não vou botar o diagrama com os valores, eu boto "R1, R2" assim que o cara bota, "C1, C2, D1, D2", eu não vou dar os valores que daí eu vou dar a Gatorra funcionando pra eles, não adianta, vou dar de mão beijada o circuito, também não tá com nada ${ }^{46}$.

Sobre esta questão, a preocupação de Tony reflete o modo como o processo de registro de marcas e patentes se mostra inacessível para a população em geral. Tony acredita ser difícil obter uma patente para a gatorra devido ao fato de que cada instrumento possui pequenas alterações no circuito e nos controles $^{47}$.

\subsection{Circuito}

O circuito em si é um desenvolvimento feito por Tony de um circuito de bateria eletrônica, que provavelmente chegou a seu conhecimento por meio de revistas com projetos de eletrônica. Partindo da constatação de que a sonoridade da gatorra é bem semelhante à de um tipo de bateria eletrônica "de dedo" comercializada entre os anos 1980 e 1990 em lojas de instrumentos musicais e de componentes eletrônicos no Brasil, procurei saber mais sobre as origens deste instrumento. Para ouvir o som de ambos os instrumentos, criei uma playlist em <https://soundcloud.com/missionariojose/sets/ exemplos-sonoros-da-slicie-e-da-gatorra $>$.

\footnotetext{
$\overline{46}$ Tony da Gatorra, informação pessoal em 18 de novembro de 2016.

47 Tony da Gatorra, informação pessoal, 6 de maio de 2016
} 


\subsubsection{Drummer Boy e SLICIE}

O uso do termo "bateria" para fazer referência a um instrumento específico é, em linhas gerais, bem delimitado pelo uso geral e faz referência a um conjunto de tambores e pratos que segue uma configuração relativamente padronizada no tocante à escolha dos instrumentos e à forma como estes são tocados, ou ao conjunto de instrumentos de percussão tocado coletivamente em contextos como o das escolas de samba no Brasil.

Já na adoção do termo no contexto de instrumentos eletroeletrônicos, existem alguns desdobramentos que destaco aqui. O correspondente mais próximo à uma bateria física e acústica convencional seria a parte dos circuito eletrônico responsável pela geração de sons eletrônicos com características de timbre, afinação e envelope dinâmico mais ou menos semelhantes às características dos instrumentos de percussão de uma bateria. A este estágio de geração de sons normalmente, mas não obrigatoriamente, é adicionado um estágio responsável pelo sequenciamento de padrões rítmicos que podem ou ser programados previamente pelo projetista que cria o instrumento, ou programados pelo usuário. $\mathrm{O}$ desenvolvimento deste conjunto de gerador de sons integrado a um sequenciador ocorre historicamente em paralelo com o estabelecimento do mercado de órgãos eletroeletrônicos, como forma de gerar acompanhamento rítmico para organistas e pianistas, e tem como marco inicial a produção da bateria eletrônica Sideman em 1959 pela empresa estadunidense Wurlitzer ${ }^{48}$. É possível, no entanto, que os sons percussivos gerados eletronicamente sejam executados por intérpretes humanos utilizando-se outras interfaces de controle, e é sobre este aspecto que entrarei em maiores detalhes.

Uma vez constatado que o som da gatorra se assemelha muito ao som de baterias como a SLICIE, procurei buscar mais informações sobre as origens deste projeto em particular $^{49}$. Em seu blog, o engenheiro eletrônico Nelson Ribeiro (2015) sugere que a SLICIE tenha sido baseada em "baterias eletrônicas de marcas comerciais da época", e aponta para uma semelhança entre este projeto e um projeto publicado na revista Popular Electronics em $1974^{50}$.

O projeto mencionado por Ribeiro foi de fato publicado em 1974 em uma coletânea de projetos organizada pelos editores da Popular Electronics intitulada Electronic Experimenter's Handbook, tendo sido publicado originalmente na edição regular da revista em julho de 1971 com autoria de John Simonton Jr. (1971), com o nome de Drummer

48 Há dois exemplos historicamente anteriores de geradores de ritmo, o Rhythmicon desenvolvido por Léon Theremin a pedido de Henry Cowell entre 1930 e 1932, e o Rhythmate produzido pela empresa Chamberlin a partir de 1957. No primeiro caso, o instrumento não chegou a ser produzido em série nem comercializado, e no segundo caso o instrumento era baseado na execução de ritmos pré-gravados em fitas magnéticas. Disponível em: <https://en.wikipedia.org/wiki/Drum_machine>. Acesso em 7 de março de 2018.

49 Neste vídeo é possível ouvir os sons de uma SLICIE: <https://www.youtube.com/watch?v= uyn6cTePSME>. Acesso em 15 de maio de 2018.

50 Disponível em:<http://electronicsartisanedynel.blogspot.com.br/2015/03/ projetosynth-diy-famosa-batearia-de.html>. Acesso em 7 de março de 2018. 


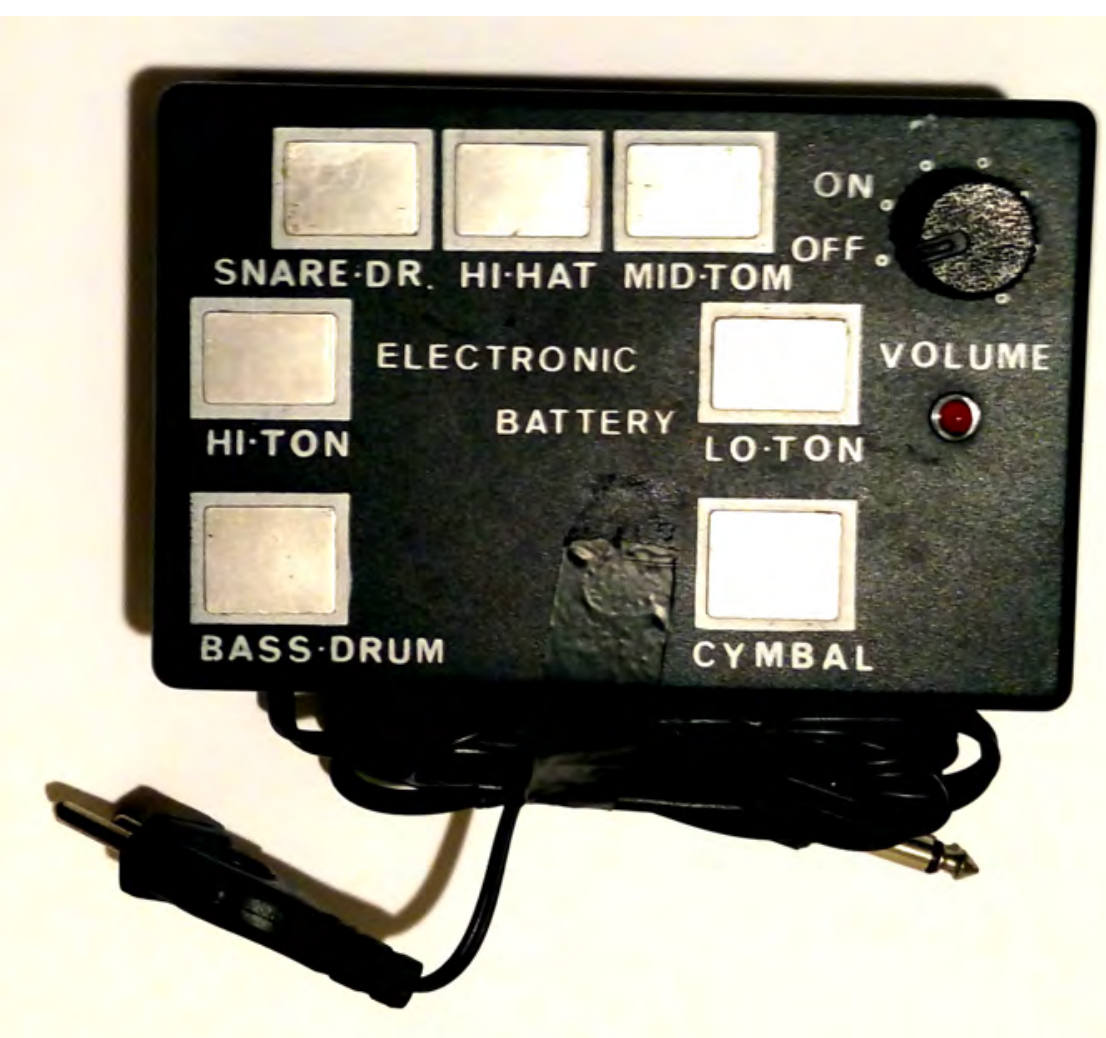

Figura 42 - Bateria eletrônica SLICIE. Foto do autor.

Boy. Outro artigo de Simonton, publicado no ano anterior, também trata da construção de um gerador de ritmos para acompanhamento, no entanto trata-se de um projeto mais simples, chamado de Thumpa-Thumpa Box. No caso da bateria Drummer Boy, esta era uma versão comercial do projeto apresentado por Simonton na Popular Electronics produzida entre 1971 e $1978^{51}$.

O projeto do Drummer Boy consiste em um gerador de sons com 6 timbres, um contador e um sistema que permite ao usuário escolher entre os 11 padrões rítmicos disponíveis ${ }^{52}$. Ambos projetos, Drummer Boy e Thumpa-Thumpa Box são baseados em osciladores do tipo duplo- $\mathbf{T}$, que como veremos adiante é um princípio semelhante ao utilizado tanto na SLICIE quanto na gatorra:

Os sons percussivos da Drummer Boy são resultado de um circuito de oscilador duplo-T amortecido, recebendo um pulso. Esta foi a base da maior parte dos sons percussivos eletrônicos anteriores ao advento da amostragem digital ou da reprodução a partir de wavetables" 53 .

No artigo de 1971, Simonton sugere também a possibilidade de montagem apenas

\footnotetext{
51 Scott Lee, informação pessoal por e-mail em 18 de janeiro de 2018

52 (SIMONTON JR., 1971, p. 28-30)

53 Scott Lee, informação pessoal em 18 de janeiro de 2018
} 
do gerador de som, para execução em performance com o ativamento dos sons a partir de chaves ou botões, e uma versão só com o gerador de som sob o nome de Percussion $\boldsymbol{P a c}$ fez parte do catálogo de 1971 da PAiA Electronics ${ }^{54}$.

Outros projetos sucederam o Drummer Boy no catálogo da PAiA que também utilizaram o mesmo princípio de osciladores duplo-T. Seu sucessor imediato, chamado de Programmable Drum Set, foi produzido entre 1978 e 1986 e vinha integrado com um sequenciador programável, e os sons percussivos eram acessáveis por meio de placas de contato na frente do dispositivo. Esta interface com placas de contato é semelhante ao que se observa na Cracklebox e na SLICIE. Atualmente a empresa produz um kit chamado Drum Tone Board que pode ser acoplado a uma interface MIDI, ou a uma interface para acionamento direto ${ }^{55}$.

Outro ponto mencionado por Nelson Ribeiro em seu blog é o contato com o criador do projeto original da SLICIE no Brasil por intermédio do pesquisador Eric Marke. Segundo Marke (2017, p. 159), o projeto da SLICIE foi desenvolvido no Brasil por George Romano. Romano teve formação em eletrônica de nível técnico na Escola Técnica Federal, em São Paulo, e também através de cursos diversos de eletrônica em escolas como o Instituto Edison e a Escola Aladim, e ainda nos anos 1960 chegou a montar Theremins por interesse pessoal. Ao longo dos anos 1970 e 1980 trabalhou junto fabricantes de órgãos eletrônicos estabelecidos no mercado nacional, como a Gambitt ${ }^{56}$ e Audac, e também fabricou órgãos de modo autônomo sob a marca Eminence ${ }^{57}$.

Antes da escola eu já mexia, eu comecei a me interessar, só pra você ter uma ideia, com o Theremim, isso já foi em 64 [...] eu fui fazer um curso de eletrônica básica, acho que era Instituto Edison, e lá na inscrição tinha várias coisas que eram feitas de eletrônica, acho que era pra incentivar aluno, né? Aí tinha uma onça [risos], uma onça rajada, você chegava a mão perto dela, e além dela acender os dois olhos dela, tinha duas lampadinhas, ela fazia aquele miado, aquele som do theremin. Eu falei, nossa, que coisa interessante isso aqui ${ }^{58}$.

O projeto da SLICIE surge a partir da demanda de criar um módulo de ritmo para ser acoplado nestes órgãos, em algum momento ao longo dos anos 1970. Ao ser entrevistado sobre este processo, Romano não recorda para qual fabricante em particular o projeto estava sendo desenvolvido, mas recorda que os módulos do projeto original eram baseados em eletrônica analógica e, dessa maneira, mais complexos para construção. A solução

\footnotetext{
54 Scott Lee, informação pessoal em 18 de janeiro de 2018

55 Scott Lee, informação pessoal em 18 de janeiro de 2018

56 <http://www.gambitt.com.br/>

57 (MARKE, 2017, p. 159)

58 George Romano, informação pessoal em $1^{\circ}$ de fevereiro de 2018
} 
proposta por Romano foi basear o projeto em outros, já existentes no mercado exterior, utilizando circuitos integrados ${ }^{59}$.

Os sons desse projeto usavam esse oscilador do tipo duplo-T, que chamam, que pode ser feito com transistor, com operacional, pode ser feito com CMOS. Isso aí é simples, se você entrar no datasheet dos integrados, ele tem as aplicações do chip, ele tem um receituário das coisas que você pode fazer com ele [...] Esse circuito é uma besteira, é muito simples, o trabalho que você tem num circuito desses é achar a frequência do bumbo, a duração, essas coisas, o circuito mesmo é simples ${ }^{60}$.

A opção de Romano foi por desenvolver o projeto usando um circuito integrado, mas em seu depoimento ele não se recorda de qual a especificação do circuito empregado. No exemplar da SLICIE a que tive acesso, a parte do circuito integrado onde normalmente se vê o número correspondente encontra-se raspada, uma prática comum na produção artesanal de circuitos eletrônicos que impede que outras pessoas copiem o circuito. Inicialmente o projeto foi desenvolvido para fabricação em dois formatos: um módulo acoplado ao órgão eletrônico e outra versão para ser fabricada e vendida como um módulo isolado, para instrumentistas usarem como acompanhamento. Além do oscilador duplo-T para produzir os sons percussivos semelhantes aos dos tambores, é necessário também criar um gerador de ruído branco para criar os sons correspondentes aos pratos e ao chimbal, e também para complementar o som correspondente à caixa clara da bateria convencional ${ }^{61}$.

Segundo Romano a inspiração para fazer uma versão sem o sequenciador para ser tocada em tempo real surgiu de um acidente: "Eu tava montando os sons numa matriz de contato, e por acidente eu esbarrei ali e tocou um som. Daí veio a ideia de usar umas chapinhas pra fazer contato e tocar" ${ }^{\prime 2}$. Romano, no entanto, não chegou a comercializar a SLICIE, tendo repassado o projeto para um colega, que fabricou a primeira versão comercializada em lojas na região da Rua Santa Ifigênia, no centro de São Paulo:

Aí eu tava lá na Casa Verde, eu tinha uma fábrica pequena, veio alguém [e eu] falei "Ó, toma isso pra você". Eu dei uma caixinha, um prototipozinho, e aí foi. Aí apareceu na Santa Ifigênia, eu acho que ele mexeu, não deve ter sido exatamente o que eu fiz, tinha um monte, qualquer porta de loja tinha um cara tocando isso a $6^{63}$.

59 George Romano, informação pessoal em $1^{\circ}$ de fevereiro de 2018

${ }^{60}$ George Romano, informação pessoal em $1^{\circ}$ de fevereiro de 2018

61 Romano não entrou em detalhes sobre a implementação do gerador de ruído branco em seu projeto, mas uma descrição de como este pode ser implementado em um projeto bastante similar pode ser encontrada em: <http://www.newtoncbraga.com.br/index.php/eletronica/57-artigos-e-projetos/ 9349-bateria-eletronica-art1839>. Acesso em 21 de maio de 2018.

62 George Romano, informação pessoal em $1^{\circ}$ de fevereiro de 2018

63 George Romano, informação pessoal em $1^{\circ}$ de fevereiro de 201 


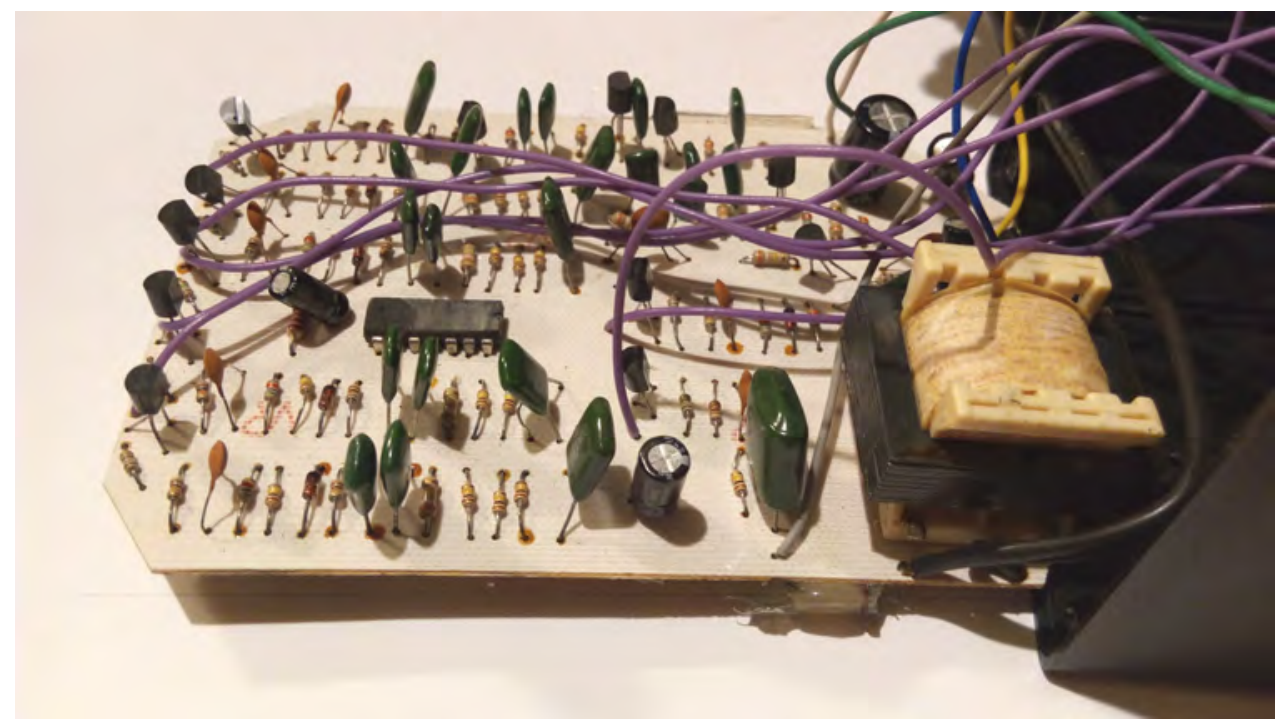

Figura 43 - Circuito da bateria SLICIE, utilizando um circuito integrado. Foto do autor.

A partir do projeto de Romero fabricantes diversos de "bateria eletrônica de dedo" surgiram, e durante um longo período estas baterias foram vendidas sob diversos nomes, como SLICIE, Dinâmica, Pontus, Slcie, Batronic 7 e Spineer, entre outros. Nelson Ribeiro (2015) afirma ter comprado sua bateria por volta de 1987, na Sta. Ifigênia, e observa a conexão entre a procura por este tipo de instrumento e o interesse crescente pela música pop eletrônica. Na última década, o interesse em resgatar instrumentos e tecnologias tidas como obsoletas pelos grandes fabricantes de instrumentos e equipamentos musicais fez com que o interesse em instrumentos como a SLICIE ressurgisse:

Tem mercado, mercado pra qualquer tipo de produto, principalmente instrumento musical que seja, até órgão eletrônico [ainda] se fabrica hoje, falaram "ah, não vai fazer mais, porque o pessoal só vai tocar sintetizador [...] tem aquele [músico] que realmente quer sentir o som, quer ver o instrumento, né? ${ }^{64}$

\subsubsection{O circuito da gatorra}

Assim como nos casos citados no item anterior, o circuito da gatorra também é baseado no mesmo princípio:

Ó, tá aqui o esquema completo [...] tu aplica o sinal aqui, entra na base. Aí ele passa pelo capacitor e entra no coletor, então ele fica assim, porque a saída é no próprio coletor, o sinal retorna, por isso que fica "puuuu" [imita o som com a boca], é legal isso aqui, né? Os caras chamam de, como é que é..., circuito T, porque é um T com

64 George Romano, informação pessoal em $1^{\circ}$ de fevereiro de 201 


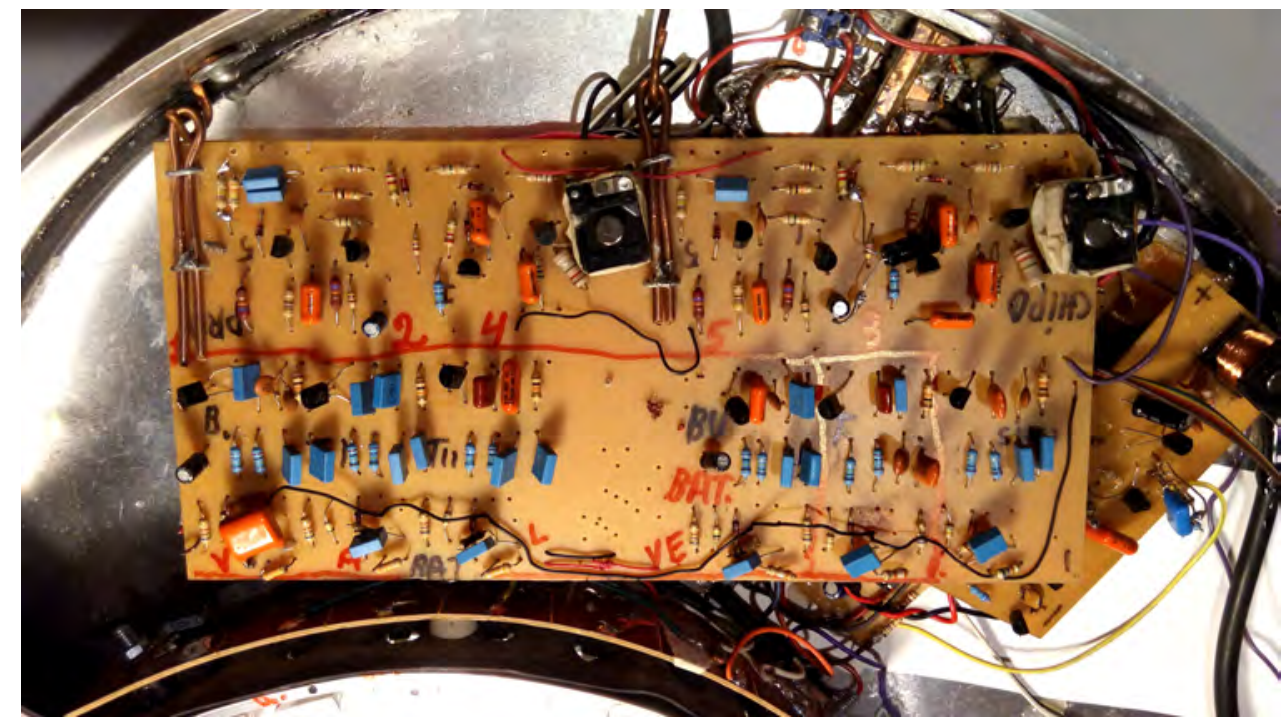

Figura 44 - Circuito da gatorra $n^{\circ} 19$. Foto do autor.

o capacitor, e um T aqui, é duplo-T. O sinal entra na base, ele vai pra saída e ele retorna de novo, tá sempre circulando. ${ }^{65}$

Tony não faz nenhuma menção ao circuito da SLICIE como influência direta no desenvolvimento do circuito da gatorra, mas é possível especular a respeito uma vez que estes instrumentos eram vendidos, na época de sua produção, em lojas de componentes eletrônicos. De todo modo, tanto Scott Lee quando George Romano afirmam que osciladores duplo-T são amplamente utilizados para criar sons percussivos, e projetos utilizando osciladores deste tipo para criar baterias eletrônicas, ao que tudo indica, circulavam em publicações voltadas para o público interessado.

O circuito da gatorra utiliza uma abordagem baseada no transistor BC549, de uso comum, e ao contrário das outras baterias eletrônicas citadas anteriormente, cada instrumento possui entre 9 e 12 sons. Normalmente alguns dos sons da gatorra possuem altura fixa, enquanto outros podem ter sua altura regulável. Os sons de altura fixa normalmente são os que se encontram na botoeira do corpo - e na botoeira correspondente do braço - e são chamados por Tony de bateria, ao passo que os sons de altura regulável são chamados por ele de sintetizador. A quantidade de sons reguláveis variou ao longo do tempo de acordo com a disponibilidade dos componentes:

E as primeiras que eu fiz, que eu coloquei um sintonizador de TV de plástico, no lugar disso aqui, tu chegou a ver aquelas primeiras gatorras? A 4, a 5, a 6, eu tinha, é de sintonia de TV, tu podia sintonizar todos os 12. Aí terminou, né, eu não consegui mais e não tem pra vender mais aquilo, aí eu uso potenciômetro. ${ }^{66}$

\footnotetext{
$\overline{65}$ Tony da Gatorra, informação pessoal em 18 de novembro de 2016.
}

66 Tony da Gatorra, informação pessoal em 18 de novembro de 2016. 


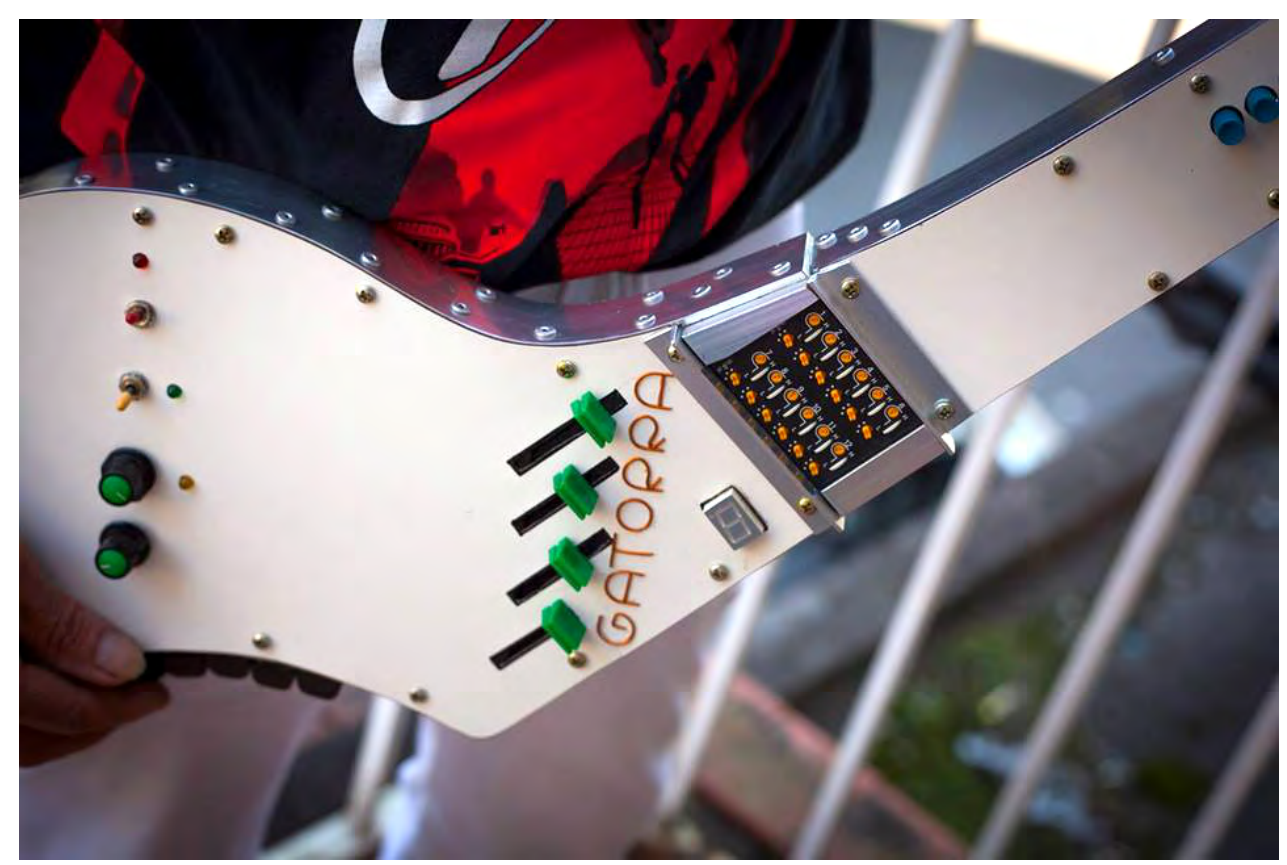

Figura 45 - Detalhe da gatorra $n^{\circ} 3$ mostrando o sintonizador de televisão utilizado para regular a altura dos sons. Foto: Binho Miranda.

Outro elemento importante no circuito da gatorra são os repetidores, construídos a partir dos circuitos integrados: "CI eu uso mais nessa programação, eu uso de contador aquele 4017, o 555 eu uso pro disparo, que é 'prrr', ele é temporizador. E o contador eu uso pra programar, eu uso até pra LED, pra ritmo" ${ }^{67}$. O uso de LEDs no circuito tende a ser um complemento decorativo, por vezes associados a alguns dos sons, acendendo quando estes são tocados ${ }^{68}$. Como mencionado, em alguns casos Tony instalou um circuito sequencial que faz alguns LEDs acenderem independentemente do que está sendo tocado.

O circuito das gatorras e minigatorras é normalmente alimentado por uma fonte externa, à qual os instrumentos se conectam por meio de um cabo do tipo XLR. Na caixa que contém a fonte também é feita a conexão da saída de áudio da gatorra. Em algum momento no período próximo à produção da gatorra $n^{\circ} 14$ também foram feitas algumas modificações na fonte, uma vez que as fontes até então geravam muito ruído adicional, e alguns dos compradores da gatorra reclamavam desta característica.

\subsection{Pontos de análise - 3}

Um teclado em formato de guitarra, e que tem som de bateria.

Cito aqui esta definição, elaborada pelo youtuber Gil Lima Tejo ${ }^{69}$, para exemplificar a

67 Tony da Gatorra, informação pessoal em 6 de maio de 2016.

68 Com exceção da gatorra $\mathrm{n}^{\circ} 5$ na qual, atendendo ao pedido de Luísa Lovefoxxx, todos os botões acionam um LED correspondente.

69 Responsável pelo canal Brinquedos que Traumatizam. Disponível em: < https://www.youtube. 
reação que a maioria das pessoas têm ao primeiro contato com a gatorra: a dificuldade de entender o instrumento de acordo com referenciais estabelecidos. O youtuber citado não é um especialista em gatorras, em instrumentos musicais ou sequer um pesquisador acadêmico, no entanto o poder de síntese desta descrição ilustra de forma muito eficiente uma espécie de confusão que se instala quando buscamos entender a gatorra como um instrumento musical convencional.

A apresentação e a sonoridade da gatorra articulam imagens estabelecidas no imaginário sobre instrumentos musicais eletroeletrônicos e digitais: a guitarra elétrica, o sintetizador analógico, o teclado ou órgão eletrônico, os controladores do tipo keytar ${ }^{70}$, a bateria eletrônica. A gatorra, no entando, não é nenhum destes por não estar conectada diretamente, ou exclusivamente, a nenhuma destas tradições. Cito a seguir as impressões sobre a gatorra de alguns músicos, que tocam gatorra e outros instrumentos, como forma de enfatizar esta ambiguidade:

Os pontos preferidos são a facilidade de execução do instrumento e o seu conceito mesmo que não declarado pelo Tony - de uma bricolagem tecnológica de componentes e sucatas industriais. Os problemas estão no projeto de seu circuito eletrônico [...] o que torna o instrumento extremamente ruidoso. [...] A minha gatorra é a de número 6, bem antiga, e segundo o Tony, ele vem aperfeiçoando o instrumento; talvez por isso a minha tenha tantos problemas nesse sentido. Ele já a levou para consertar umas 3 vezes, já trocou fonte, cabos, mas o problema persiste ${ }^{71}$.

Eu gosto do fato dela ser uma bateria eletrônica vestível, e que se pode tocar como uma guitarra em vez do formato tradicional de caixa, comum às baterias eletrônicas operadas com pads. As principais limitações são ela ser muito ruidosa, difícil de controlar e alguns dos sons, especialmente os contínuos, são um pouco desagradáveis. O instrumento se adequa bem à música experimental, noise, mas eu sinto que há lacunas que impedem que seja usado em estilos musicais mais convencionais ${ }^{72}$.

Eu vejo ela como um sintetizador, só que ao invés de teclado ela tem outra configuração. Dá pra fazer sons percussivos, drones, até melodias se você tiver paciência para testar. Ela não deixa de ser uma silhueta de guitarra / baixo, por causa de seu desenho, forma de ser empunhada e o tipo de cabo utilizado, que permite conectá-la a pedais de efeito e multiplicar suas possibilidades [...] Adoro os drones que podem ser feitos com os potenciômetros, ainda mais cruzá-los para gerar ruídos ultra graves.

$\mathrm{com} /$ watch? $\mathrm{v}=\mathrm{v} 4 \mathrm{uf0} \mathrm{cmbcUY}>$. Acesso 14 de maio de 2018

70 Keytars, aglutinação das palavras keyboard e guitar, são sintetizadores e controladores MIDI cuja interface é baseada em um teclado de órgão convencional, construídos de modo a serem vestidos e tocados em pé, como uma guitarra

71 Sérgio Pinto, informação pessoal em 15 de março de 2017.

72 Graeme Ronald, informação pessoal em 14 de novembro de 2017. 
Por outro lado, os botões que Tony fez para a mão direita são um pouco frágeis. Um deles quebrou, vou levá-la para ele arrumar ${ }^{73}$.

Outros autores já realizaram algumas análises e discussões sobre a gatorra e sobre Tony em seus trabalhos, por diferentes perspectivas, os quais cito aqui. Em relação ao universo de práticas de alteração de circuitos, Fernandez (2013, p. 166) analisa a a atividade de Tony da Gatorra como sendo mais próxima à vertente do hardware hacking, devido ao fato de Tony não modificar circuitos, e sim construí-los inteiramente, a partir da adaptação de projetos e de suas próprias criações. Fernandez entretanto observa semelhanças entre Reed Ghazala e Tony, no tocante ao visual hippie e ao discurso sobre o desenvolvimento de uma nova consciência em uma nova era. Obici (2014, p. 157-159) relaciona a produção de Tony com o conceito de gambioluteria, ou ainda uma "luteria pós-punchê", feita por um "técnico em eletrônica gaúcho que se descobre músico pós-punk depois de inventar seu próprio instrumento" ${ }^{74}$. Conter (2016, p. 145) também chama atenção para o visual hippie e para alguns elementos associados ao punk no conjunto da obra de Tony da Gatorra.

É interessante observar a constante relação feita pelos autores entre Tony da Gatorra e dois movimentos a priori contrastantes na cultura popular urbana do século XX, o movimento hippie e o binômio punk e pós-punk, com algumas citações também à música industrial, gênero este que tende a ser associado esteticamente ao pós-punk. Sobre o aspecto hippie, esta observação normalmente está associada ao visual utilizado por Tony no dia-a-dia e em suas apresentações - cabelos longos amarrados com uma faixa onde lê-se a palavra "PAZ", colares com o símbolo da paz ${ }^{75}$, calças boca-de-sino coloridas e pintadas à mão -, à iconografia presente nas capas de disco e outros materiais confeccionados por Tony, e também no teor de parte de suas letras de música e depoimentos, que fazem referência à Era de Aquário e à busca pela paz mundial.

Já a associação ao movimento punk e ao pós-punk se relaciona com dois eixos. O primeiro diz respeito ao elemento de protesto, que permeia toda a obra de Tony e é um tema bastante associado ao discurso do movimento punk desde o início deste. Musicalmente, no entanto, Tony é mais associado à estética presente na produção do pós-punk e da música industrial, devido às características de sons percussivos sem tratamento adicional da gatorra, e à forma como Tony entoa suas canções ${ }^{76}$. Além de ser comparado a artistas do

73 Marcelo Bergamin Conter, informação pessoal em 8 de dezembro de 2016.

74 (OBICI, 2014, p. 5)

75 Trata-se, na verdade, do símbolo criado em 1958 pelo designer britânico Gerald Holtom para a Campanha pelo Desarmamento Nuclear. Disponível em: < https://en.wikipedia.org/wiki/Campaign_ for_Nuclear_Disarmament>. Acesso em 19 de maio de 2018.

76 A título de referência incluo aqui algumas faixas de artistas do pós-punk: Warm Leatherette The Normal < https://www.youtube.com/watch?v=ITSB_6m4up4>; The Fall - Bingo Master's Breakout <https://www.youtube.com/watch?v=u3ZvO4pcTHs>; The Human League Being Boiled < https://www.youtube.com/watch?v=I_NStTkSRQw>; Cabaret Voltaire - Nag Nag Nag < https://www.youtube.com/watch?v=FsLJUD8_MVA>. Acesso em 19 de maio de 2018. 
pós-punk como o vocalista Mark E. Smith, da banda The Fall ${ }^{77}$, também são frequentes as comparações a outros artistas, seja pela crueza de sua performance, como no caso do bluesman estadunidense Son House, seja por uma estranheza percebida pelos ouvintes, como no caso de artistas inclassificáveis como a banda estadunidense The Shaggs $^{78}$, o projeto Objeto Amarelo do artista paulistano Carlos Issa, e o músico britânico Mark Tucker ${ }^{79}$, entre outros: "Pra quem gostava de Shaggs, Wesley Willis e Daniel Johnston, ele era a personificação do músico outsider brasileiro" 80

Se por um lado, Tony comumente manifesta seu gosto por artistas que estão de uma forma ou de outra associados ao imaginário do movimento hippie ${ }^{81}$, como Pink Floyd, Creedence Clearwater Revival, Led Zeppelin, decerto não teve contato direto com o punk, pós-punk ou a música industrial britânica ou estadunidense, e ainda que seja possível especular que alguma derivação destes estilos tenha chegado até ele nos anos 1970 ou 1980, Tony não faz menção de predileção ou influência de artistas associados a estes gêneros. Acho importante observar aqui que, assim como a gatorra, Tony também escapa de classificações pré-definidas, sendo necessário constantemente recorrer a um universo de referências um técnico em eletrônica gaúcho hippie que faz música que parece com pós-punk mas lembra outras coisas - para tentar explicar do que se trata. E, naturalmente, todo este universo de referências não dá conta da explicação, no máximo situa o interlocutor em uma situação de esperar o inesperado.

Em Lima (2015, p. 390), realizo uma aproximação entre o trabalho de Tony e os conceitos de programação e de caixa preta proposto por Flusser $\left(2011\right.$, p. 11) ${ }^{82}$, propondo que a gatorra é o resultado de uma reprogramação de diferentes caixas pretas, no sentido em que seu construtor a cria a partir do desmonte e do reaproveitamento de diferentes caixas pretas descartadas no cotidiano de uma sociedade hiperindustrializada: Tony abre outras caixas pretas e de lá retira o que necessita para construir a sua própria, ele desfaz programações anteriores para programar uma caixa preta à sua maneira. Conter (2016, p. 144-154), realiza uma aproximação semelhante, definindo a gatorra como um

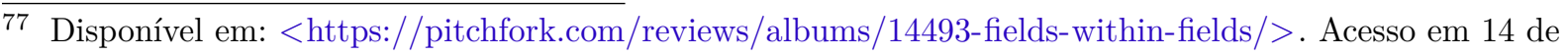
maio de 2017.

78 Formada pelas irmãs Wiggin, a banda The Shaggs adquiriu notoriedade após seu disco de estréia Philosophy of the World, lançado em 1969, ter sido elogiado pelo músico Frank Zappa como um de seus preferidos, ainda nos anos 1970, e também ter sido classificado como "o pior disco jamais gravado" pelo jornalista Chris Connelly da revista Rolling Stone, quando do relançamento do álbum em 1980. Disponível em: < https://en.wikipedia.org/wiki/Philosophy_of_the_World>. Acesso em 19 de maio de 2018.

79 Disponível em: <http://www.buzzmag.co.uk/uncategorized/gruff-rhys-v-tony-da-gatorra-live-review/ $>$. Acesso em 20 de fevereiro de 2018.

80 Dago Donato, informação pessoal em 9 de março de 2018.

81 Ver apêndice B.3.1

82 Em "Filosofia da caixa preta" Flusser argumenta sobre como os aparelhos que empregamos no cotidiano são programados previamente em seu processo de produção industrial, e utiliza a máquina fotográfica como exemplo de como estes aparelhos são caixas pretas das quais o usuário, ou operador, só conhece o input e o output, desconhecendo os detalhes do "processo codificador" no interior dos aparelhos. 
"objeto de ressignificação das caixas pretas musicais" 83 , através do qual Tony chama para si o papel de programador $^{84}$. A ênfase de Conter se dá na reação à obsolescência dos objetos e materiais:

Toda mídia que não triunfou [...] acaba por reprogramar a história triunfalista dos aparelhos. O obsoleto, a sucata, portanto, não dizem respeito ao que morreu, ao que perdeu sua utilidade, e sim ao que persiste resistindo na diferença. O obsoleto é uma reserva de potência de agenciamentos de baixa definição: baixa definição porque, insistindo no caso da gatorra, inscreve-se em uma zona de indeterminação, dificultando sua inscrição como uma máquina de samplear, uma máquina punk, uma finger drumming, uma bricolagem de mídias mortas ou como um instrumento para $\operatorname{protestar}^{85}$.

Esta "zona de indeterminação" citada por Conter pode ser articulada, acredito, com a ideia de desobediência tecnológica em Oroza, utilizada por Obici como forma de entender práticas de alteração de circuito, gambiarras e a criação de dispositivos sonoros a partir do reaproveitamento de outros. Ambos os autores enfatizam este aspecto de uma resistência, de uma postura política associada à escolha por "agenciamentos de baixa definição" 86 ou pelo reaproveitamento de tecnologias tidas como obsoletas.

A partir destes observações argumento que, mesmo que não esteja claro no discurso de Tony da Gatorra uma postura de resistência específica em relação aos processos de obsolescência programada ou às tendências do mercado de instrumentos musicais eletroeletrônicos, a própria existência da gatorra enquanto objeto e instrumento revela uma resistência inerente aos seus componentes que se recusam a desaparecer, voltando à superfície por meio da atividade artística. Outro ponto importante a ser observado sobre esta relação com os objetos é o fato de que Tony, em sua formação e no desenvolvimento da gatorra, não teve contato com elementos da cultura do-it-yourself ligada às técnicas de alteração de circuitos que, segundo Fernandez, buscam iluminar a caixa preta de Flusser.

O isolamento social, econômico e cultural no qual Tony aprende eletrônica, coloca seu aprendizado em prática e desenvolve a gatorra é bastante diverso daquele em que se desenvolvem as comunidades de DIY dos hackerspaces e do movimento maker. Parafraseando Conter observo que, em Esteio, o do-it-yourself não é uma opção ou um hobby, é um modus operandi, uma estratégia de sobrevivência ${ }^{87}$. O modus operandi deste

83 (CONTER, 2016, p. 146)

84 (CONTER, 2016, p. 153)

85 (CONTER, 2016, p.154)

86 Conter utiliza aqui o termo agenciamento no sentido de instrumento de desterritorialização, de acordo com o pensamento de Deleuze e Guattari. Não cabe neste trabalho um aprofundamento nestes autores, mas creio que o conceito de agenciamento pode ser entendido aqui como uma ação dezestabilizante de um contexto estabelecido.

87 Cf. (CONTER, 2016, p. 145). 
contexto socioeconômico, portanto, convida à desobediência tecnológica. Bens de consumo estão programados para serem obsoletos, habitam um universo cuja ordem é ter uma vida útil relativamente curta, serem descartados e substituídos por novos modelos ou novas tecnologias. A prática da gambiarra no sentido de "saída técnica que se vale dos meios disponíveis", como citei anteriormente ${ }^{88}$, é uma forma de desobediência tecnológica que ressignifica objetos técnicos a partir do seu reaproveitamento, e do seu uso imprevisto.

Não há nada numa chapa de fórmica, de alumínio ou de acrílico que informe se esta vai ser utilizada em um móvel ou em uma gatorra, assim como um componente eletrônico como um resistor ou um transistor pode ser reaproveitado em qualquer tipo de circuito eletrônico, desde que compatível com a necessidade. No entanto, o aproveitamento extremo de restos de chapas de fórmica, alumínio e acrílico, revendidos por quilo por algum profissional que já não tenha como aproveitar estas sobras, revela uma vida útil destes materiais que não está prevista na programação de sua produção. Da mesma forma, componentes eletrônicos não são produzidos, a priori, para serem reutilizados, uma vez integrados a um circuito é ali que foram programados para permanecer, e no entanto no contexto da produção de Tony da Gatorra não há porque não reaproveitá-los.

A prática de recorrer a formas e objetos já produzidos como matéria-prima para novas obras já foi mencionada anteriormente em 1.3, e retorno a este tópico aqui para chamar a atenção para outro autor que também usa a ideia de programação e reprogramação, neste caso no contexto da produção artística no pós-modernismo. Para Bourriaud, os artistas atuais não "compõem, mas programam formas", em uma estratégia que busca "inscrever a obra de arte numa rede de signos e significações, em vez de considerá-las como forma autônoma ou original ${ }^{89}$.

Acredito que no caso de Tony da Gatorra e de seu instrumento podemos tanto observar reprogramações dos programas no sentido de Flusser, quanto no sentido de Bourriaud. No sentido da caixa preta tecnológica, Tony se torna seu próprio programador, como sugere Conter, ao buscar o conhecimento que permite adentrar e iluminar as caixas pretas como forma de buscar sua subsistência. Dessa forma lida de modo crítico com a programação destes aparelhos, desconstrói e reconstrói suas programações para mantê-los ativos, úteis, uma necessidade compartilhada com a comunidade na qual está inserido não por uma motivação estética, mas por uma necessidade prática, pela impossibilidade de repor aquele aparelho por outro mais novo, como quer a indústria que produz aqueles aparelhos.

Mas seu modus operandi como técnico em eletrônica se transforma em modus vivendi ao transformar sua subsistência em um instrumento que lhe permite recriar a própria vida, iluminar as possibilidades criativas de uma comunidade deixada à margem de 
um pensamento desenvolvimentista. Ao fazê-lo, Tony também realiza uma reprogramação no sentido proposto por Bourriaud, combinando imagens visuais, sonoras e textuais que desconcertam o espectador / ouvinte acostumado aos cânones da tradição artística ocidental. Não se trata, portanto, de não encontrar referências para descrever o artista e sua música, trata-se de entrar em contato com um novo esquema de como acessar estas referências. De modo semelhante ao que Scarassatti (??p. 158]scarassatti2015) descreve sobre Smetak, Tony dá ao seu instrumento o estatuto de música.

Em sua práxis, Tony personifica duas tendências contrastantes: a do inventor do século XX que busca com sua invenção contribuir para a humanidade, mas que também busca fabricá-la em série e construir uma reputação a partir disso, e a do artista à margem da sociedade, criando uma numerosa população de readymades de tudo que encontra, a partir dos excessos de uma sociedade hiperindustrializada. Se por um lado existe um bricoleur ou um gambiólogo em ação - no reaproveitamento de componentes eletrônicos, no uso de tampas de pasta de dente para fazer botões de controle - também há uma espécie de nanoempreendedor que busca os melhores preços para componentes que não estejam disponíveis em forma de sucata, que compra sobras alumínio e acrílico por quilo, que busca melhorar a relação de custo com os materiais / produtos que desenvolve.

Entretanto na obra de Tony da Gatorra não há conflito entre estas duas tendências: ao partir de uma situação de extrema escassez de recursos e praticar sua arte em ambientes mais favorecidos materialmente, Tony exemplifica e incorpora paradoxos que estão presentes na contemporaneidade e na prática artística atual. O radicalismo estético de sua produção é uma forma de entendermos como tradição e abandono das tradições podem conviver. 


\section{Conclusão}

Utilizo duas citações de Weber para introduzir esta parte do trabalho:

Mas a elevação do experimento como princípio de investigação foi uma realização do Renascimento. Os grandes inovadores na arte foram os pioneiros do experimento. Leonardo e seus pares e, principalmente, os experimentadores na música do século XVI com seus pianos experimentais. Partindo destes círculos o experimento entrou na ciência, principalmente através de Galileu, e na teoria através de Bacon; e daí foi adotado pelas disciplinas científicas das universidades do continente [...] Para os artistas experimentadores como Leonardo, assim como para os inovadores musicais, a ciência representava o caminho para a arte verdadeira, e desta forma o caminho para a verdadeira natureza ${ }^{1}$.

A racionalização dos sons parte historicamente, e de modo regular, dos instrumentos. O comprimento da flauta de bambu na China, a tensão das cordas da cítara na Hélade, o comprimento das cordas do alaúde na Arábia e do monocórdio nos mosteiros ocidentais, tudo isso serviu para a medição física das consonâncias. Mas nestes casos afinaram-se finalmente os instrumentos de acordo com os sons que se ouvia. Os instrumentos eram necessários apenas para a determinação exata e fixação dos intervalos de consonância, portanto estavam à serviço de fins tonais requeridos de antemão. Mas o inverso também era possível e ocorreu: certos instrumentos antigos de sopro da América Central indicam uma repartição dos furos de acordo com pontos de vista puramente simétricos-ornamentais, aos quais, por conseguinte, os sons a serem produzidos tinham de se submeter ${ }^{2}$.

Dois pontos importantes que servem de base para a argumentação que busco desenvolver neste capítulo são introduzidos nas citações acima. O primeiro trecho é do texto A ciência como vocação ${ }^{3}$, e utilizo aqui esta citação como mote para uma discussão sobre a relação de mútua influência entre a ideia de instrumento musical e a ideia de instrumento científico no ocidente a partir do século XVII, e sobre como esta relação pode servir de base para uma discussão sobre o instrumento musical no contexto deste trabalho.

Já a segunda citação é do texto Os Fundamentos Racionais e Sociológicos da Música ${ }^{4}$, onde a afirmação expõe a relação entre a materialidade dos instrumentos e

1 (WEBER, 1991, p. 141-142). Itálicos no original

2 (WEBER, 1995, p. 127)

3 O texto é a transcrição de uma fala de Weber na Universidade de Munich, em 1917, e a versão utilizada neste trabalho é a tradução de 1946, na edição de Gerth e Mills.

4 Escrito por Weber por volta de 1911 e publicado pela primeira vez em 1921 (WEBER, 1995, p. 23-24) 
sua influência em alguns sistemas musicais, e também uma exposição sobre as origens do temperamento na música europeia ${ }^{5}$.

Chamo aqui a atenção para estas observações tendo como referência o seu uso em Théberge (1997, p. 166), relacionando-as com outros autores que tratam de questões semelhantes e buscando aprofundar a discussão em relação à pesquisa desenvolvida no presente trabalho.

Na primeira citação Weber aponta para uma influência dos instrumentos musicais experimentais do século XVI na transformação do papel do instrumento como ferramenta científica. Neste trecho do texto citado, o foco de Weber não é a música, e sim a relação entre o nascimento do pensamento científico como o conhecemos com a experimentação científica e com o uso de instrumentos que viabilizam esta experimentação. No contexto histórico de que trata Weber, as áreas do conhecimento humano no ocidente não tinham suas fronteiras delimitadas tão claramente - esta delimitação de disciplinas é uma consequência da chamada Revolução Científica dos séculos XVI e XVII - e a múltipla influência entre diferentes atividades e áreas do conhecimento era parte integrante deste pensamento que podemos chamar de protocientífico.

Hankins \& Silverman (1999) escrevem sobre o mesmo período com foco neste processo de transformação do instrumento no ocidente, e em seu trabalho chamam a atenção para o fato de que os primeiros instrumentos científicos são em essência aprimoramentos técnicos de instrumentos que já existiam, e eram amplamente usados em outras áreas da atividade humana. O trabalho destes autores enfatiza principalmente a influência que o uso de instrumentos nas chamadas magias naturais - que incluíam a astronomia, a alquimia, entre outras - teve na adoção de instrumentos como ferramentas para o processo científico:

A maioria dos instrumentos "filosóficos", que foram a base da filosofia experimental enquanto esta se desenvolvia durante a Revolução Científica, já existiam em versões prematuras nas magias naturais ${ }^{6}$.

Não cabe aqui aprofundar questões relativas a este período, mas chamo atenção para dois pontos que são discutidos neste contexto: a forma como a experimentação na música e nas magias naturais por meio de instrumentos dá origem ao instrumento filosófico-científico, e a mudança de paradigma na ideia de instrumento provocada por este novo tipo de instrumento, e que viria a modificar a forma como o instrumento musical é entendido.

Sobre o primeiro ponto, tanto o instrumento musical como o instrumento nas magias naturais possui uma relação com o desvelar dos segredos da natureza, levando-se 
em conta o aspecto mágico deste processo, um aspecto de encantamento. Pode-se dizer que a partir da revolução científica o instrumento científico é responsável por uma espécie de desencantamento do mundo, na medida em que despe a natureza do seu aspecto mágico e substitui essa perceção pelo entendimento científico. Entretanto, o encantamento não desaparece por completo, e de certa forma persiste um aspecto de encantamento na forma como instrumentos científicos desempenham este papel de revelar e demonstrar os segredos da natureza, assim como na forma como os instrumentos musicais o fazem de modo totalmente diferente.

Iazzetta (2012, p. 226) aproxima os conceitos de tecnologia do encantamento e encantamento da tecnologia - propostos pelo antropólogo britânico Alfred Gell - da relação entre a técnica e o valor atribuído ou percebido em uma obra musical através da sua performance. Gell argumenta que o fascínio exercido pelas obra de arte está relacionado com a dificuldade que temos em compreender seu processo de "tornar-se um objeto no mundo acessível a mim por um processo técnico que, uma vez que transcende a minha compreensão, sou obrigado a interpretar como sendo mágico"7, ao que Iazzetta atribui esta mesma capacidade de encantamento à técnica na performance musical.

Com base nestas referências, afirmo que este aspecto de encantamento também persiste nos instrumentos discutidos no presente trabalho. Por mais que estejamos habituados em alguma medida a conviver com eixos Cardan, televisores portáteis e rádios obsoletos nada nestes objetos e aparelhos sugere, a priori, sua ressignificação como Torre, Narva 2 ou Polyradiotron. Acredito que se desenrola aqui um processo semelhante ao que Gell relata sobre a obra O babuíno e o filhote de Pablo Picasso, em que a "transubstanciação espirituosa" de um objeto em outro confere à obra este aspecto mágico, de encantamento ${ }^{8}$. O aspecto readymade nestes instrumentos, neste caso, colabora para o fascínio que eles exercem como objetos em si, e para além do encantamento associado à sua existência, uma outra dimensão deste fascínio é articulada pela possibilidade de performance musical nestes mesmos instrumentos.

De modo semelhante, ao dissecarmos a construção eletrônica da gatorra, vemos que eletronicamente ela é um instrumento simples, sendo possível inclusive categorizá-la de acordo com a taxonomia Hornbostel-Sachs, mais especificamente na categoria 531.222.2: "Sintetizadores analógicos de circuito transistorizado com sons previamente programados, parcial ou inteiramente polifônicos, gerando e processando sinais elétricos sonoros utilizando síntese subtrativa" ". Tal classificação, por exemplo, colocaria a gatorra na mesma categoria de um instrumento como a bateria eletrônica TR-808, que também utiliza princípios semelhantes para a geração de sons, e naturalmente outras baterias como a SLICIE e a Drummer Boy, mesmo que se tratem de instrumentos diferentes nas formas como são

7 (GELL, 1999, p. 169)

8 (GELL, 1999, p. 173)

9 (Musical Instrument Museums Online (MIMO), 2011, p. 22). 
utilizados, nos contextos em que aparecem e no tipo de música que resulta deles. Talvez a única característica, além do táxon, compartilhada por estes quatro instrumentos - gatorra, TR-808, Drummer Boy, SLICIE - seja algo como um sinal tecnográfico - uma "marca estética deixada por alguma tecnologia em algum produto ou comportamento cultural"10 que estes deixam pelas músicas por onde passam e que, de alguma forma, permitiu que esta pesquisa encontrasse uma conexão entre eles.

No entanto, a existência da gatorra não está limitada a sua possibilidade técnica como circuito eletrônico. Seu "tornar-se um objeto no mundo" ocorre por uma combinação de processos, não somente técnicos, que contribuem para o encantamento desta tecnologia. A forma como ela chama a atenção das pessoas está nesta dimensão do encantamento, em transformar algo simples e corriqueiro em uma coisa mágica, aproximando mais a figura de Tony da Gatorra de uma espécie de tecnoxamã do que de um inventor do século XX como Robert Moog.

Retomando o segundo ponto, mencionado acima, sobre a mudança de paradigma na ideia de instrumento musical a partir do instrumento científico, observo que alguns autores utilizam esta mudança como ponto de partida para discutir questões relativas a práticas musicais contemporâneas. Miskalo (2014, p. 171-178) realiza uma discussão sobre práticas musicais contemporâneas que fazem uso de computadores e sistemas digitais, utilizando como referência o trabalho de Rothbart ${ }^{11}$, e Ihde (2007) utiliza esta mesma mudança de paradigma como base para discutir questões relativas ao uso de diferentes suportes fonográficos na contemporaneidade. De modo semelhante, acredito que alguns elementos relativos a esta mudança de paradigma possam ser utilizados para discutir questões relativas à produção pesquisada neste trabalho.

Mesmo antes da revolução científica, alguns aspectos do instrumento musical sempre serviram à finalidade de desvendar os mistérios da natureza. O monocórdio, citado por Weber como "base da medição racional do som de todo o Ocidente" 12 , habita o limiar entre instrumento musical e instrumento científico por um período bastante longo, se considerarmos o seu uso como instrumento filosófico-científico por Pitágoras ${ }^{13}$, e seu uso tanto como instrumento de referência quanto como instrumento musical na idade média. Sachs (1940, p. 269) aponta para o uso do monocórdio já no século X, por influência de Boécio, como instrumento de referência para o aprendizado dos intervalos naturais por cantores, o que demonstra uma preocupação com um embasamento científico destes intervalos, pautando-os por um cálculo científico, e não pela percepção e intuição musical. Versões do monocórdio utilizadas como instrumento musical propriamente dito

\footnotetext{
10 (CAESAR, 2008, p. 286)

11 ROTHBART, D. Philosophical instruments: minds and tools at work. Chicago: University of Illinois Press, 2007

12 (WEBER, 1995, p. 127)

13 (THÉBERGE, 1997, p. 164)
} 
são registradas por volta do século XII ${ }^{14}$, como por exemplo o instrumento conhecido como Tromba Marina ${ }^{15}$.

O novo tipo de instrumento surgido ao longo do século XVII se diferencia da noção tradicional de instrumento que até então denotava instrumentos de medição ${ }^{16}$ ou instrumentos musicais. Os novos instrumentos filosóficos se caracterizam pela capacidade de expandir a percepção humana, como o telescópio e o microscópio, ou de criar condições particulares de observação, como no caso da bomba de ar, e tiveram um impacto determinante nas ciências naturais ao viabilizar uma nova abordagem para a pesquisa e experimentação científica. No sentido musical, o uso da palavra organon para denotar um instrumento musical é anterior, remontando ao texto De architectura de Vitrúvio ${ }^{17}$ e, como vimos anteriormente na seção sobre terminologia, à distinção feita por Aristóteles entre instrumentos animados e inanimados.

Mas a partir dos instrumentos filosóficos e da Revolução Científica, o instrumento musical passa a ser enxergado por uma perspectiva diferente. Segundo Ihde (2007, p. 12):

A ação humana é mediada pelo instrumento para produzir seu resultado. Se em um caso é o conhecimento maior obtido por Galileu através de seu telescópio [...] em outro são os sons transformados produzidos através da execução do instrumento, sons que são tão diferentes dos sons vocais comuns como as imagens vistas através do telescópio diferem daquelas da observação a olho nu.

Esta perspectiva também é observada por Iazzetta (2012, p. 228), articulando esta "transformação" da natureza com as características do aparelho em Flusser:

Pode-se pensar que há no instrumento musical uma dimensão de aparelho: ele não apenas trabalha sobre contingências físicas da natureza para produzir sons, mas ele informa sobre sons que, ao mesmo tempo que remetem à natureza, são estranhos a ela. A flauta pode imitar o pássaro que canta na gaiola, mas sua virtude consiste em soar como um não-pássaro.

Este aspecto de mediador da relação entre o observador e aquilo que se observa também é discutido por Hankins \& Silverman, para quem instrumentos científicos podem ser vistos como uma espécie de linguagem, por serem coisas "cujo propósito é nos ajudar

14 (SACHS, 1940, p. 270)

15 Apesar do nome, a tromba ou trombeta marina é um monocórdio tocado com arco. Sachs (1940, p. 292) afirma que há pouca informação sobre as origens e o nome do instrumento, especulando que o nome "trombeta" tenha relação com a semelhança entre o perfil harmônico do instrumento e a escala do trompete natural, e que o nome "marina" faria referência à Virgem Maria, devido ao uso do instrumento em conventos e monastérios.

16 (HANKINS; SILVERMAN, 1999, p. 3)

17 (RESTLE, 2008, p. 257). No texto original, Vitrúvio faz referência ao Hydraulis. 
a analisar e raciocinar sobre outras coisas" ${ }^{18}$. No contexto do século XVII este aspecto é entendido, inicialmente, como negativo, pois assim como a descrição da natureza por meio de figuras de linguagem pode dar espaço para ambiguidades, também a observação dela por meio de instrumentos poderia ser ambígua.

Esta relação com a ideia de linguagem se modifica quando da introdução de instrumentos que registram fenômenos naturais por meio de gráficos, como é o caso do Fonoautógrafo desenvolvido por Édouard-Léon Scott de Martinville em $1857^{19}$. A produção destes gráficos experimentais é tida como uma nova espécie de linguagem visual, uma linguagem universal que permitiria uma conexão direta com os fenômenos naturais, e Hankins \& Silverman também chamam a atenção para a relação entre o surgimento deste tipo de gráfico com o desenvolvimento da semiótica de J. H. Lambert no século XVIII, e de Charles S. Peirce no século XIX ${ }^{20}$.

Como parte da discussão sobre a relação entre instrumentos e linguagem, Hankins \& Silverman (1999, p. 8) descrevem o uso do emblema como forma de representação, ao utilizar "tanto palavras quanto imagens para criar uma alegoria com um sentido oculto". É possível fazer uma analogia direta entre esta noção de emblema com a obra de alguns criadores mencionados neste trabalho, em particular a de Walter Smetak, no sentido de seus instrumentos possuírem essa natureza emblemática. Outro exemplo é a ideia de emblema sonoro na produção de Scarassatti, termo usado para definir um objeto que compartilha com a plástica sonora a importância ao aspecto visual, mas que pode ser ativado para a geração de sons. Assumindo um posicionamento estético e sonoro radicalmente diferente daqueles de Smetak e Scarassatti, os instrumentos do Bazar de Hostilidades Sonoras também possuem esta natureza emblemática, tanto pela escolha de suas matérias-primas quanto pelas modificações a que são submetidas. Recapitulando o enunciado de emblema sonoro - "uma forma complexa, composta por um aglutinado de pequenos símbolos que se desdobram em potência latente para uma sonoridade resultante" - observo aqui que é possível aplicá-lo tanto para o Tzim Tzum quanto para Jezebel Crackletoy e Rosemary.

Como mediadores, instrumentos são empregados para "mensurar, produzir imagens, modelar fenômenos e alterar o estado natural" 21 . Dessa maneira, o instrumento permite abordar a natureza de uma forma inédita, estabelecendo mas também interferindo na relação entre objeto e observador. A música, em especial a noção abstrata de música no ocidente, é ouvida "através" dos instrumentos que a fazem. Desde o surgimento do

18 (HANKINS; SILVERMAN, 1999, p. 8)

19 O fonoautógrafo de Scott de Martinville seria a base para o desenvolvimento posterior de fonógrafos como o de Charles Cros e o de Thomas Edison em 1877. O fonógrafo proposto por Cros em um projeto também de 1877, chamado de Paelofone, não chegou a ser realizado devido ao aparecimento do fonógrafo de Edison. Disponível em: < https://fr.wikipedia.org/wiki/Charles_Cros $>$. Acesso em 22 de abril de 2018

20 (HANKINS; SILVERMAN, 1999, p. 118-141)

21 (HANKINS; SILVERMAN, 1999, p. 11) 
fonógrafo, esta relação adquire um novo contorno, e a música passa a ser literalmente ouvida através de diversos instrumentos de escuta. Novamente, é negociando com o mediador que se viabilizam diferentes modos de recepção e criação sonora, e nestes processos podemos entender que existe o desenvolvimento de uma linguagem, o desenvolvimento de uma gramática da escuta baseada naquilo que o instrumento-mediador oferece. Para atingir resultados tanto com instrumentos científicos quanto com instrumentos musicais, Ihde propõe, é necessária a aquisição de habilidades específicas, de modo que o resultado do instrumento depende do treinamento do usuário ${ }^{22}$, o que também aproxima o instrumento da ideia de linguagem.

Complementa esta relação, segundo Hankins \& Silverman, o aspecto demonstrativo dos instrumentos científicos, que se desdobra em alguns níveis: o que é demonstrado pela própria existência do instrumento, a saber um determinado status quo e a possibilidade de seu uso; a demonstração de fenômenos e a criação de efeitos que não ocorreriam naturalmente; e, em um terceiro nível, a demonstração e confirmação de teorias por meio de instrumentos ${ }^{23}$. Este último nível da demonstração de teoria é especialmente válido para uma aproximação com o instrumento musical. O instrumento musical tradicional demonstra a teoria que estrutura a música por ele tocada. Ele é, como no caso do teclado do piano, das divisões dos trastes em um instrumento de corda, das escolhas que determinam o timbre de um instrumento, a materialização de uma teoria. Por sua vez, é o aspecto material que determina em alguns momentos quais os caminhos da elaboração teórica, como mencionado por Weber na segunda citação que abre este capítulo.

Retomarei adiante esta discussão sobre a materialidade dos instrumentos, mas antes busco uma aproximação destes aspectos - linguagem, mediação e demonstração - com a produção aqui estudada. Ainda sobre linguagem, destaco o caso dos circuitos eletrônicos que constituem uma forma de linguagem em si mesmos. Proponho um exercício de olhar para o aprendizado de eletrônica como referência: é possível aprender por meio de um curso formal, e no entanto as práticas e oficinas de alteração de circuito propõem outra abordagem para este processo, um pouco como um viajante que se encontra de repente em uma cidade desconhecida e resolve desvelar seus caminhos não por meio de um mapa em seu telefone celular, mas através de uma deriva particular. Vejo uma conexão entre este tipo de deriva "técnica" com uma frase dita por Tony da Gatorra, a caminho de um show em Concórdia, Santa Catarina: "O circuito diz uma coisa e tu acha outra coisa dentro dele" ${ }^{24}$.

Em todos os casos estudados, acredito, os instrumentos produzidos desempenham o papel de mediador entre seus criadores e as demais pessoas, sejam elas também musicistas ou o público em geral. Como demonstradores, os instrumentos aqui estudados demonstram

\begin{tabular}{ll}
\hline 22 & (IHDE, 2007, p. 12) \\
23 & (HANKINS; SILVERMAN, 1999, p. 11-13) \\
24 & Informação pessoal em 21 de abril de 2016.
\end{tabular} 
a possibilidade técnica ou mágica de suas próprias existências, e também a possibilidade de criar novas sonoridades e proposições musicais. Entretanto, ao contrário do que afirmo anteriormente sobre o terceiro nível de Hankins \& Silverman em relação a instrumentos musicais tradicionais, acredito que se, por um lado, os instrumentos aqui estudados nos capítulos 2 e 3 demonstram um posicionamento estético, intelectual ou artístico, não vejo estes instrumentos como demonstradores de teorias num sentido mais estrito, como ocorre em casos como o de Harry Partch, Marco Antônio Guimarães ou em projetos como o de Patrick Ozzard-Low. Neste sentido posso especular que talvez atuem mais como mediadores ou demonstradores de disposições criativas mais abrangentes.

Ainda sobre mediação e demonstração Hankins \& Silverman sugerem que a instrumentalização das ciências naturais é um processo em que a natureza do próprio instrumento vai definir os contornos do conhecimento produzido. O instrumento não é um mediador ou demonstrador neutro, pois, como afirmam :

Instrumentos possuem vida própria. Eles não são meros seguidores da teoria; em muitos casos eles determinam a teoria, porque instrumentos determinam o que é possível, e o que é possível determina em grande parte o que pode ser pensado ${ }^{25}$.

Esta última citação faz referência a uma relação dialética, que se estabelece no uso de instrumentos científicos, entre a elaboração teórica e a materialidade dos instrumentos científicos. Como mencionado, a segunda citação de Weber no início deste capítulo também delineia esta dialética, e é partindo desta referência que Théberge (1997, p. 166) afirma que "cultura material e sistemas abstratos de pensamento e organização musical formam uma relação dialética da maior importância no fazer musical".

Acrescento que, nesta relação dialética, é comum que o aspecto material seja colocado em segundo plano, visto como uma consequência ou um suporte à elaboração teórica e à vontade criativa. A partir das referências citadas neste capítulo, busco aqui elaborar a partir deste ponto uma discussão baseada na ideia de que a porção material desta relação é pouco explorada, e que esta possui um potencial de revelar aspectos importantes, principalmente ao levarmos em consideração que os criadores estudados no presente trabalho não necessariamente possuem uma formulação teórica estabelecida $a$ priori sobre quais as finalidades de suas criações.

Buscando estabelecer um arcabouço teórico para discutir as relações entre músicos e o mercado de instrumentos musicais nas últimas décadas do séc. XX, Théberge (1997, p. 163) sugere o uso do modelo proposto pelo etnomusicólogo estadunidense Alan Merriam, enfatizando a área definida como cultura material musical. Se segundo Théberge o piano como mercadoria estabelece uma relação de produção e distribuição industrial que

$\overline{25}$ (HANKINS; SILVERMAN, 1999, p. 5) 
se torna um paradigma orientador de uma indústria, a produção aqui pesquisada não tem essa ambição, mas acredito que o modelo de Merriam permaneça válido como referência para uma análise.

Merriam (1964, p. 45) chama a atenção para a possibilidade de olhar para os instrumentos para além da taxonomia estabelecida, observando também seus "princípios de construção, materiais empregados, detalhes decorativos, métodos e técnicas de performance, tessitura musical, sons produzidos e escalas", assim como sua dimensão simbólica, função social, e também os aspectos econômicos associados à existência deste instrumento:

O papel econômico dos instrumentos também é importante. Pode haver especialistas na sociedade que se sustentam construindo instrumentos, mas estes existindo ou não, a produção de um instrumento inevitavelmente envolve o tempo econômico de seu produtor. Instrumentos podem ser comprados e vendidos; podem ser encomendados; de todo modo, sua produção é parte da economia da sociedade como um todo. Instrumentos podem ser considerados como símbolos de riqueza; podem ser possuídos por indivíduos; sua posse por indivíduos pode ser reconhecida, mas ignorada em termos práticos; ou podem se constituir um item de riqueza coletiva de uma vila ou tribo. A distribuição dos instrumentos tem uma importância considerável nos estudos sobre difusão e na reconstrução da história de uma cultura, e em alguns casos é possível sugerir ou confirmar movimentos de populações por meio de instrumentos. ${ }^{26}$

Neste ponto, proponho uma aproximação entre este aspecto econômico e o conceito de limiar da invenção que pode ser feita por dois caminhos. Por um lado, há uma aproximação pelo lado das narrativas oficiais ou, como na citação de Conter em 3.4, da "história triunfalista dos aparelhos". Existe um desenvolvimento tecnológico no século XX pautado por prerrogativas industriais, militares e econômicas que viabiliza a existência e a disponibilidade de materiais, técnicas e saberes amplamente acessíveis e propagandeados. Este desenvolvimento gera, como já observei anteriormente, as condições para que existam criadores como os irmãos Baschet, Robert Moog, Donald Buchla, Bart Hopkins e suas criações, e que estas criações encontrem espaços de ressonância de modo a se tornarem referências culturais.

Por outro lado, as mesmas condições econômicas que geram este desenvolvimento tecnológico também geram uma produção em excesso, em parte devido à prática industrial da obsolescência programada. Levando isso em consideração, proponho uma outra aproximação com o conceito de limiar da invenção que se dá pela via do excesso e do descarte - relacionada com a oferta de readymades sonoros e com as práticas de alteração de circuitos - e também pela forma como estas relações econômicas ocorrem nas porções menos favorecidas da sociedade, em especial de países em desenvolvimento, como é o 26 (MERRIAM, 1964, p. 45) 
caso do Brasil. Estes limiares da invenção possuem traçados diversos para Esteio ou para bairros diferentes de São Paulo, Belo Horizonte ou Porto Alegre, que em muito divergem daqueles observados na Califórnia ou em Nova Iorque nos anos 1960 e 1970.

Dessa maneira, a produção discutida aqui neste trabalho se insere na economia como um todo, mas também o faz através de outras microeconomias. Existe a microeconomia do reaproveitamento, existe a microeconomia do mercado de nicho, existem microeconomias ligadas a cenários musicais específicos, existem microeconomias baseadas em trocas. Os restos e as sobras existem como expurgo de um modelo de economia global e de suas contingências locais, produzindo uma televisão que é descartada em uma caçamba, tanques de combustível descartados ou mesmo o exemplo dos sintonizadores de TV que, ao ficarem mais escassos, mudam a configuração do instrumento do qual fazem parte, como mencionado no capítulo 3 .

A relação com a escassez neste exemplo se dá tanto porque os sintonizadores disponíveis nos televisores antigos ou já foram utilizados, ou ainda estão em uso em televisores que ainda funcionam, quanto porque o componente parou de ser utilizado em novos televisores, portanto a procura pelas peças também diminui, e consequentemente sua produção e disponibilidade no mercado de peças de reposição. A gatorra é o instrumento possível nas condições em que ela é criada e revela uma dinâmica de acesso ao conhecimento e aos meios de desenvolvimento de tecnologias. Neste sentido podemos considerá-la como um instrumento marginal, à margem do desenvolvimento "triunfalista" do mercado de instrumentos musicais.

Sua existência também pode ser entendida como uma contravenção técnica, e por existir independentemente dos rumos traçados pela indústria a gatorra é um instrumento "tecnologicamente desobediente", no sentido proposto por Oroza. Se no universo pesquisado por Oroza "a falta de bens, mais do que de dinheiro, moldou a atitude cubana em relação aos objetos" ${ }^{27}$, no caso brasileiro podemos afirmar que nos encontramos em algum lugar no meio do caminho entre este extremo e aquilo que se observa nos países desenvolvidos. A este respeito, Oroza comenta:

Ao realizar oficinas com estudantes europeus, eu percebi que havia uma tendência a produzir objetos que pareciam emergir da crise. Não é fácil inserir um estudante europeu em um ambiente contingencial ${ }^{28}$

Théberge, ao buscar essa relação dialética em Weber e relacioná-la com Merriam, enfatiza o lado material desta dialética entre produção musical e objetos musicais. Introduzo a seguir uma outra referência que também enfatiza o lado material desta relação.

27 (ROGNOLI; OROZA, 2015, p. 3)

28 Disponível em: <https://walkerart.org/magazine/ernesto-oroza-technological-disobedience-cuba > Acesso em 10 de maio de 2018 
O reconhecimento da importância das coisas como objetos de estudos em si mesmas tem sido o cerne de uma corrente de pesquisas na antropologia, apontada por Miller (1998, p. 3) como tendo início entre o final dos anos 1970 e os anos 1980, a partir de trabalhos de autores como Bourdieu, Appadurai e do próprio Miller. Miller em particular defende que os objetos não sejam interpretados como signos ou símbolos que representam abstrações ${ }^{29}$, e que estes estudos em cultura material estão mais interessados em investigar como as "coisas fazem as pessoas"30 do que o oposto.

No tocante à construção de instrumentos musicais e, mais especificamente, no contexto deste trabalho, um caminho é aderir à proposta feita por Miller de deixarmos de lado o adágio modernista segundo o qual "a forma segue a função"31. No desenvolvimento da gatorra e de outros instrumentos aqui estudados é possível inverter este vetor e afirmar que a função segue a forma - ou talvez que a disfunção siga a deformação. Não há, tecnicamente, uma razão específica para se construir um sintetizador modular do tamanho de uma estante de livros, em plenos anos 2010, quando o processo técnico realizado por este instrumento pode ser feito em um computador portátil com as dimensões de uma revista de histórias em quadrinhos. No entanto, um complexo jogo de descoberta de funções se estabelece ao nos depararmos com um objeto como a série de sintetizadores Jolymod: a função segue a forma.

Nesta inversão da proposta modernista trata-se de, a partir de elementos dados, descobrir quais as funções possíveis, e quais os potenciais ocultos na forma e nos materiais.

Um conceito que está presente nesta abordagem de Miller é o de humildade das coisas, segundo o qual "objetos determinam o que fazemos à medida que estamos inconscientes da capacidade que têm de fazê-lo" 32 . A influência dos objetos se dá justamente pelas propriedades opostas às que normalmente nos chamam a atenção, atingindo esta condição de nos influenciar principalmente por estarmos familiarizados com $\operatorname{eles}^{33}$, por terem se tornado imperceptíveis.

Chamo a atenção, neste ponto, para a recorrência de eventos semelhantes nos relatos de Reed Ghazala, Michel Waisvisz e George Romano, sobre a descoberta acidental de potenciais sonoros em circuitos eletrônicos. É importante sem dúvida levar em consideração que estas três ocorrências se processam em condições diferentes - e que certamente surgirão exemplos semelhantes em relatos sobre o desenvolvimento de circuitos eletrônicos para instrumentos musicais em outros lugares - mas acredito que esta coincidência releva alguns aspectos que podem ter relação com a noção de humildade das coisas.

Nestes casos, a ação do acaso está atrelada a uma certa normalidade e à desa-

29 (MILLER, 2010, p. 21).

30 (MILLER, 2010, p. 113).

31 (MILLER, 2010, p. 119).

32 (MILLER, 2010, p. 120).

33 (MILLER, 2010, p. 133). 
tenção característica da nossa relação com os objetos que nos rodeiam: Reed Ghazala "acidentalmente" gera um curto-circuito em um amplificador jogado no fundo de uma gaveta, Michel Waisvisz e seu irmão René brincam de realizar concertos em família com os circuitos internos de rádios portáteis - talvez não por acaso no país-sede da empresa Philips -, Romano esbarra acidentalmente em um circuito destinado a outra finalidade. Longe de tentar atribuir um caráter sobrenatural a estes eventos, chamo a atenção justamente para o oposto: eles só acontecem porque envolvem objetos e situações aos quais não se está dando uma importância excessiva.

Este é um aspecto que perdura quando começamos a buscar mais informações sobre os processos de desenvolvimento destes circuitos: as informações, em geral, são poucas e pouco detalhadas. O circuito que dá origem à Drummer Boy, à SLICIE e à gatorra viaja desapercebido por fronteiras econômicas, políticas de comércio exterior, limitações de acesso às tecnologias mais recentes, vai sendo carregado a tiracolo na produção de fabricantes de componentes eletrônicos, contrabandistas de instrumentos musicais e eletrodomésticos. Os projetos viajam clandestinamente na troca de informações sobre eletrônica, e florescem em pontos diferentes do planeta. Os caminhos aqui percorridos, se não chegam a sugerir ou confirmar movimentos de populações como propõe Merriam, pelo menos esboçam uma rede de múltiplas influências através do interesse neste tipo de objeto.

A desatenção aos detalhes do circuito é tal que o palpite de buscar mais informações ocorreu por uma especulação aural, pela percepção acidental de que sinais tecnográficos semelhantes aparecem vindo de lugares diferentes. Mesmo com uma quantidade considerável de instrumentos eletroeletrônicos rodeando a produção musical nas últimas décadas, pouca atenção é dada ao aspecto material, aos circuitos, aos seus princípios de funcionamento fora das fronteiras de uma comunidade de interessados muito pequena. No entanto, seus componentes e circuitos humildemente demonstram conexões ou coincidências.

George Romano, como relatado, repassa o circuito para um amigo produzir em série sem maiores preocupações - "aquilo ali é uma coisa besta" - e por motivos diversos não há uma ênfase nos detalhes. Ao longo dos anos 1980 um projeto baseado em osciladores duplo- $\mathrm{T}$, que em outros momentos deu origem a produtos de grande sucesso, passa a ser considerado obsoleto, uma coisa que não merecia tanta atenção. O trabalho de arqueologia relatado por Nelson Ribeiro (2015) no processo de reviver uma SLICIE original dos anos 1980 é um indicador importante deste aspecto.

No caso da gatorra, a importância dada ao circuito em si também não é tanta, há uma ênfase maior dada ao processo de torná-la real através do reaproveitamento de materiais. Neste sentido a existência de um instrumento como a gatorra revela uma rede complexa de transmissão de conhecimentos e deslocamento de materiais. Seu surgimento em um lugar específico diz tanto sobre o lugar em si, quando sobre as pessoas envolvidas, quanto sobre as condições que permitem que este instrumento surja da forma que surgiu 
nos anos 1990 .

Para além desta discussão sobre os circuitos eletrônicos, outros instrumentos aqui estudados explicitam, ou subvertem, a humildade das coisas ao colocarem-nas de volta no foco das atenções. Em instrumentos como a Geralda, a Liga do Tempo e os capacetes para deriva sonora, objetos corriqueiros e normalmente invisíveis são trazidos para a linha de frente de uma produção sonora experimental, seu potencial de exploração sonora é revelado no momento em que são expostos e tirados desta condição de humildade.

Miller (2010, p. 195) também relaciona seu conceito de humildade das coisas com a noção de uma possível agência dos objetos em Gell, proposta por este autor, segundo Miller, como forma de "transcender a oposição entre coisas e pessoas", abordando dessa forma a produção artística como uma tecnologia do encantamento. Justamente por serem corriqueiros, cotidianos, os objetos agem sobre seus usuários de forma silenciosa, determinam a ação destes usuários de acordo. E mesmo em um processo consciente de ressignificá-los como instrumentos musicais, eles determinam em grande parte o que é possível ser feito, quais as sonoridades podem ser desvendadas.

O trabalho de pesquisa descrito aqui também foi influenciado por estas contigências de ordem prática. Muitos dos informantes que poderiam ter sido consultados não foram encontrados, alguns mesmo tendo sido localizados e contactados não deram retorno. Muitas das informações que em outras épocas estiveram publicadas na internet hoje já não podem ser encontradas online, estando apenas parcialmente disponíveis em recursos como o wayback machine, no entanto sem recursos multmídia como imagens, vídeos e mídias sonoras. Estes entraves, no entanto, transformam-se em dados de pesquisa, são em si indicadores de que esta é uma produção que não está no centro das atenções. As histórias que são narradas neste trabalho não são histórias de acertos, mas de tentativas, de carreiras que seguem caminhos não-lineares, documentários inacabados, discos que atrasam por causa de problemas com o empresário. De certa forma, lidar com a efemeridade desta produção e seus registros é em si um estudo sobre aspectos impermanentes dentro da própria materialidade dos objetos aqui pesquisados.

Munido, por um lado, da desobediência tecnológica à autoridade dos objetos e, por outro, da humildade e agência dos objetos, como referências de análise, acredito que o caminho da pesquisa sobre estes objetos aqui estudados permite observar nuances que uma abordagem musicológica ou organológica mais tradicional não revelaria, e acredito também que haja um potencial considerável em termos de possíveis desdobramentos deste trabalho.

Assim como o instrumento determina o tipo de teoria, o instrumento determina que tipo de música se pode fazer. Os instrumentos aqui estudados, neste sentido, servem como demonstrações desta condição sonora atual. E olhar para estes objetos e para a forma como estes agenciam a prática sonora abre um panorama de referências para análise, 
e de formas pelas quais podemos desvelar processos de criação 


\section{Referências}

AGAmBen, G. O que é o contemporâneo? Chapecó: Argos, 2009. Citado na página 94.

BAILEY, T. B. W. Micro Bionic: Radical Electronic Music 65 Sound Art in the 21st Century. [S.l.]: Belsona, 2012. Citado 2 vezes nas páginas 48 e 49.

BANDEIRA, A. D. Música móvel crítica. Dissertação (Mestrado) - Universidade de São Paulo, São Paulo, 2015. Citado na página 102.

BASCHET, B. Structures sonores. Leonardo, v. 1, n. 4, p. 393-403, October 1968. Citado 2 vezes nas páginas 31 e 32.

BASCHET, F. The Sound Sculptures of Bernard and François Baschet. Barcelona: Edicions de la Universitat de Barcelona, 2017. (Col-lecció impactes). Citado na página 31.

BATTIER, M. Une nouvelle géométrie du son. le paradoxe de la lutherie électronique. Les Cahiers de l'IRCAM: Recherche et Musique, v. 7, p. 43-56, 1995. Citado na página 24.

BORBA, T.; GRAÇA, F. L. Lutherie. In: Dicionário de Música. Lisboa: Edições Cosmo, 1963. Citado na página 24.

BOURRIAUD, N. Pós-produção: como a arte reprograma o mundo contemporâneo. São Paulo: Martins Fontes, 2009. Citado 2 vezes nas páginas 46 e 143.

BREND, M. Strange Sounds: Offbeat instruments and sonic experiments in Pop. San Francisco: Backbeat Books, 2005. Citado na página 53.

CAESAR, R. O loop como promessa de eternidade. In: ANPPOM - ASSOCIAÇÃO NACIONAL DE PESQUISA E PÓS-GRADUAÇÃO EM MÚSICA. Anais do XVIII Congresso da Associação Nacional de Pesquisa e Pós-Graduação em Música. [S.l.], 2008. p. 286-290. Citado na página 148.

CAGE, J. A year from Monday: new lectures and writings. Middletown: Wesleyan University Press, 1967. Citado na página 44.

CALEGARIO, F. Probatio: A physical prototyping toolkit based on morphological chart of instrumental inheritance for designing digital musical instruments. Tese (Phd Thesis) Universidade Federal de Pernambuco, Recife, Março 2017. Citado na página 110.

CHADABE, J. Electric Sound: The Past and Promise of Electronic Music. New Jersey: Prentice Hall, 1997. Citado na página 53.

CHESSA, L. A metaphysical orchestra: researching and reconstructing the intonarumori. In: CELANT, C. C. G. (Ed.). Art or Sound? [S.l.]: Fondazione Prada, 2014. p. 148-152. Citado 2 vezes nas páginas 29 e 30.

CHION, M. Musiques, Médias, Technologie. [S.l.]: Flammarion, 1994. Citado 2 vezes nas páginas 45 e 52.

COLLINS, N. Introduction: Composers inside electronics: Music after david tudor.

Leonardo Music Journal, v. 14, p. 1-3, 2004. Citado na página 59. 
COLLINS, N. Handmade Electronic Music: The Art of Hardware Hacking. London and New York: Routledge, 2006. Citado na página 63.

COLLINS, N. A solder's tale: Putting the "lead"back in "lead users". Pervasive Computing, v. 7, n. 3, p. 32 - 38, July - September 2008. Citado 5 vezes nas páginas 56, 57, 61, 62 e 63 .

COLLINS, N. Before Apple There Was Kim - the Microcomputer, Music and Me. 2009. Http://www.nicolascollins.com/texts/microcomputermusic.pdf. Citado 3 vezes nas páginas 62, 63 e 64 .

COLLINS, N. Semiconducting - making music after the transistor. In: IAZZETTA, F.; COSTA, R. (Ed.). Anais do IV Seminário Música Ciência e Tecnologia. São Paulo, 2012. p. 25 - 30. Citado na página 61.

CONTER, M. B. LO-FI: Agenciamentos de baixa definição na música pop. Tese (Doutorado) - Universidade Federal do Rio Grande do Sul, Porto Alegre, 2016. Citado 5 vezes nas páginas 119, 120, 140, 141 e 142.

COSTA, V. Os 10 anos do encun. Claves, n. 9, p. 1-2, Novembro 2013. Citado na página 82.

COX, C.; WARNER, D. (Ed.). Audio Culture: Readings in Modern Music. New York: Continuum, 2005. Citado 2 vezes nas páginas 48 e 49.

CUTLER, C. Plunderphonia. In: COX, C.; WARNER, D. (Ed.). Audio Culture: Readings in Modern Music. New York: Continuum, 2005. cap. 24, p. 138 - 156. Citado na página 46.

DEMERS, J. Listening through the noise: the aesthetics of experimental electronic music. Oxford: Oxford University Press, 2010. Citado na página 46.

D'HARNONCOURT, A. Marcel duchamp. In: D'HARNONCOURT, A.; MCSHINE, K. (Ed.). Introduction. New York: The Museum of Modern Art / The Philadelphia Museum of Art, 1973. cap. Introduction, p. 33-45. Citado 3 vezes nas páginas 43, 44 e 46.

DOURADO, H. A. Luteria. In: Dicionário de termos e expressões da música. [S.1.]: 34, 2004. Citado na página 24.

DRISCOLL, J.; ROGALSKY, M. David tudor's "rainforest": An evolving exploration of resonance. Leonardo Music Journal, v. 14, p. 25-30, 2004. Citado 2 vezes nas páginas 59 e 60 .

DUCHAMP, M. The Writings of Marcel Duchamp. London: Thames and Hudson, 1973. Citado 2 vezes nas páginas 43 e 44 .

(ED.), E. B. Luthier. In: BLOM, E. (Ed.). Grove's Dictionary of Music and Musicians. 5. ed. New York: Macmillan \& Co. Ltd., 1954. v. 5. Citado na página 24.

(ED.), M.-C. K. Luthier. In: Dictionnaire de la Musique. Paris: Larousse-Bordas, 1999. Citado na página 24.

EMMERSON, S. "live"versus "real-time". Contemporary Music Review, v. 10, n. 2, p. 95-101, 1994. Citado na página 45. 
FERnANDEZ, A. M. Circuito Alterado em Três Atos: Abrir, Tatear e Multiplicar. Dissertação (Mestrado) — Universidade de São Paulo, São Paulo, 2013. Citado 12 vezes nas páginas $24,47,51,69,73,74,76,77,97,113,140$ e 219.

FERNANDEZ, A. M.; LIMA, J. G. A. Soundcheck with nicolas collins. In: CAMPESATO, L.; CHAVES, R.; IAZZETTA, F. (Ed.). Sonologia 2016. São Paulo, 2016. p. 225-234. Citado 4 vezes nas páginas 45, 52, 56 e 67.

FERREIRA, A. Luteria. In: FERREIRA, M. d. A. M. B. (Ed.). Novo dicionário Aurélio da língua portuguesa. Curitiba: Positivo, 2009. Citado 2 vezes nas páginas 23 e 24.

FLUSSER, V. Filosofia da caixa preta: ensaios para uma futura filosofia da fotografia. São Paulo: Annablume, 2011. Citado na página 141.

GELL, A. The art of anthropology. In: Oxford: Berg, 1999. cap. The Technology of enchantment and the enchantment of technology, p. 159-186. Citado na página 147.

GHAZALA, Q. R. Circuit-bending and living instruments. Experimental Music Instruments, v. 8, n. 1, p. 23-28, September 1992. Citado 2 vezes nas páginas 51 e 52.

GHAZALA, Q. R. Circuit-bending and living instruments: Of a future. Experimental Music Instruments, v. 14, n. 4, p. 63-71, June 1999. Citado na página 51.

GHAZALA, Q. R. The folk music of chance electronics: Circuit-bending the modern coconut. Leonardo Music Journal, v. 14, p. 97-104, 2004. Citado 3 vezes nas páginas 51, 52 e 67.

HANKINS, T.; SILVERMAN, R. Instruments and the Imagination. Princeton: Princeton University Press, 1999. Citado 5 vezes nas páginas 146, 149, 150, 151 e 152.

HELMHOLTZ, H. On the Sensations of Tone as a Physiological Basis for the Theory of Music. New York: Dover, 1954. Citado na página 28.

HERTZ, G.; PARIKKA, J. Zombie media: Circuit bending media archaeology into an art method. Leonardo, v. 45, n. 5, p. 424-430, 2012. Citado 4 vezes nas páginas 47, 48, 51 e 52 .

HOLMES, T. Electronic and Experimental Music. 2. ed. New York: Routledge, 2002. Citado na página 53.

HOPKIN, B. What this is about - our purpose and our plans. Experimental Music Instruments, v. 1, n. 1, p. 1, 1985. Citado na página 43.

HOPKIN, B. Musical Instrument Design. Tucson: See Sharp Press, 1996. Citado na página 43.

HOPKIN, B.; LANDMAN, Y. Nice Noise: Modifications and preparations for guitar. San Anselmo: Experimental Music Instruments, 2012. Citado na página 43.

HORNBOSTEL, E. M. von; SACHS, C. Classification of musical instruments. The Galpin Society Journal, v. 14, p. 3-29, 1961. Citado 2 vezes nas páginas 26 e 27.

HOUAISS, A. Lutherie. In: Dicionário da Língua Portuguesa. [S.l.]: Editora, 2010.

Citado 2 vezes nas páginas 23 e 24. 
HOVANCSEK, M. The instruments of qubais reed ghazala. Experimental Music Instruments, v. 7, n. 5, p. 6-7, April 1992. Citado na página 51.

HOVANCSEK, M. John hajeski's portable anarchy. Experimental Music Instruments, v. 7, n. 4, p. 8-9, January 1992. Citado na página 51.

IAZZETTA, F. Performance na música experimental. In: UNIVERSIDADE DE AVEIRO. Performa' 11 - Encontros de investigação em performance. [S.l.], 2011. p. 1 - 10. Citado 2 vezes nas páginas 73 e 74 .

IAZZETTA, F. Técnica como meio, processo como fim. In: VOLPE, M. A. (Ed.). Teoria, Crítica e Música na Atualidade. Rio de Janeiro: Universidade Federal do Rio de Janeiro, 2012, (Simpósio Internacional de Musicologia da UFRJ, v. 2). p. 225-230. Citado 2 vezes nas páginas 147 e 149 .

IAZZETTA, F. H. de O. Sons de silício: Corpos e Máquinas Fazendo Música. Tese (Doutorado) - Pontifícia Universidade Católica - PUC, São Paulo, 1996. Citado na página 64.

IHDE, D. Technologies-musics-embodiments. Janus Head, v. 10, n. 1, p. 7-24, 2007. Citado 3 vezes nas páginas 148, 149 e 151.

JORDÀ, S. Instruments and players: Some thoughts on digital lutherie. Journal of New Music Research, v. 33, n. 3, p. 321-341, 2004. Citado na página 24.

JORDÀ, S. Digital Lutherie: Crafting musical computers for new musics' performance and improvisation. Tese (Phd Thesis) — Universitat Pompeu Fabra, Barcelona, 2005. Citado 2 vezes nas páginas 24 e 64.

KARTOMI, M. J. On concepts and classifications of musical instruments. Chicago: University of Chicago Press, 1990. Citado 5 vezes nas páginas 24, 25, 26, 27 e 28.

LIMA, J. G. A. Observações sobre o papel das ferramentas digitais na música experimental contemporânea brasileira. Dissertação (Mestrado) - Universidade de São Paulo, São Paulo, 2013. Citado 6 vezes nas páginas 45, 48, 63, 69, 102 e 219.

LIMA, J. G. A. Experimental music and the reprogramming of apparatuses. In: GUERRA, P.; MOREIRA, T. (Ed.). Keep it simple, make it fast: An approach to underground music scenes. Porto: Universidade do Porto, 2015. p. 385-391. Citado na página 141.

MACHADO, C. Manual de Instauração \#01: Fazendo seu próprio Ritimifiqueitor. Porto Alegre: Instituto de Investigação de Projetos Criativos, 2011. Online. Citado na página 88.

MARKE, E. A história da Música Eletrônica Brasileira. São Paulo: LiteraRUA, 2017. Citado 2 vezes nas páginas 89 e 134 .

MARQUES, H. Luthier. In: Dicionário de termos musicais. Lisboa: Editorial Estampa, 1986. Citado na página 24.

MERRIAM, A. P. The Anthropology of Music. Evanston, Illinois: Northwestern University Press, 1964. Citado na página 153. 
MILLER, D. Why some things matter. In: MILLER, D. (Ed.). Material Cultures: Why some things matter. [S.1.]: UCL Press, 1998. cap. 1, p. 3-21. Citado na página 155.

MILLER, D. Stuff. Cambridge: Polity, 2010. Citado 2 vezes nas páginas 155 e 157.

MISKALO, V. K. ¿Música?: processos e práticas de criação e performance em um ambiente de pesquisas em sonologia. Tese (Doutorado) — Universidade de São Paulo, São Paulo, 2014. Citado 3 vezes nas páginas 69, 106 e 148.

MOOG, R. A. Voltage-controlled electronic music modules. Journal of the Audio Engineering Society, v. 13, n. 3, p. 200-206, 1965. Citado na página 57.

Musical Instrument Museums Online (MIMO). Revision of the Hornbostel-Sachs Classification of Musical Instruments by the MIMO Consortium. 2011. Online. Disponível em: <http://network.icom.museum/fileadmin/user_upload/minisites/cimcim/documents/ H-S_20classification_20final_20version_20_282013_29_20without_20editorial_ 20markings-2.pdf $>$. Citado 2 vezes nas páginas 28 e 147.

NÉSPOLI, E. Luteria experimental e improvisação musical no ensino de música. In: SANTIAGO, G. (Ed.). Uso de recursos tecnológicos no ensino musical. São Carlos: EDUFSCAR, 2017. p. 329-351. Citado na página 96.

OBICI, G. L. Gambiarra e Experimentalismo Sonoro. Tese (Tese de Doutorado) Universidade de São Paulo, São Paulo, 2014. Citado 17 vezes nas páginas 24, 29, 35, 37, 46, 69, 75, 77, 87, 92, 97, 106, 113, 114, 140, 143 е 219.

OROZA, E. Desobediencia Tecnológica. De la revolución al revolico. 2012. Web page. Disponível em: <http://www.ernestooroza.com/ desobediencia-tecnologica-de-la-revolucion-al-revolico/>. Citado na página 76 .

OZZARD-LOW, P. 21st Century Orchestral Instruments: Acoustic instruments for alternative tuning systems. London, 1998. Citado na página 42.

PAOLI, J. S. Smetak Som e Espírito. Salvador: Assembléia Legislativa do Estado da Bahia, 2011. Citado 2 vezes nas páginas 38 e 86.

PARTCH, H. Genesis of a Music. New York: Da Capo, 1974. Citado 2 vezes nas páginas 33 e 34 .

PINCH, T.; TROCCO, F. The social construction of the early electronic music synthesizer. In: BRAUN, H.-J. (Ed.). Music and Technology in the Twentieth Century. Baltimore: Johns Hopkins University Press, 2000. p. 67-83. Citado 2 vezes nas páginas 57 e 58.

PINCH, T.; TROCCO, F. Analog Days: The invention and impact of the Moog Synthesizer. Cambridge: Harvard University Press, 2002. Citado na página 58.

PINTO, S. Não se faz mais música como antigamente. In: TRAGTENBERG, L. (Ed.). O ofício do compositor hoje. São Paulo: Perspectiva, 2012. p. 267-283. Citado 2 vezes nas páginas 119 e 129.

PINTO, T. A. Música e Eletrônica no Brasil: Vôos abortados de uma pesquisa frutífera. Dissertação (Mestrado) — Universidade de São Paulo, São Paulo, 2002. Citado 7 vezes nas páginas $69,70,71,72,73,74$ e 76. 
RAAIJMAKERS, D. Cahier-M: A Brief Morphology of Electric Sound. Leuven: Leuven University Press, 2000. Citado 3 vezes nas páginas 54, 67 e 119.

RESTLE, C. Organology: The study of musical instruments in the 17th century. In: SCHRAMM, H.; SCHWARTE, L.; LAZARDZIG, J. (Ed.). Instruments in Art and Science: On the Architectonics of Cultural Boundaries in the 17th Century. [S.1.]: De Gruyter, 2008, (Theatrum Scientiarum, v. 2). p. 257-268. Citado na página 149.

REYNOLDS, S. Rip it Up and Start Again: Postpunk 1978-1984. London: Faber and Faber, 2005. Citado 2 vezes nas páginas 48 e 50.

RIBEIRO, A. A. Uakti: um estudo sobre a construção de novos instrumentos musicais acústicos. Belo Horizonte: C/Arte, 2004. Citado 6 vezes nas páginas 24, 29, 39, 40, 41 e 42 .

RIBEIRO, N. A famosa bateria de dedo ou mão dos anos 80! 2015. Disponível em: <http:// electronicsartisanedynel.blogspot.com.br/2015/03/projetosynth-diy-famosa-batearia-de. html>. Citado 3 vezes nas páginas 132, 136 e 156.

ROGNOLI, V.; OROZA, E. "worker, build your own machinery!" a workshop to practice the technological disobedience. In: COOPER, T. et al. (Ed.). Proceedings of the First international conference on Product Lifetimes and the Environmentirst international conference on Product Lifetimes and the Environment. Nottingham, 2015. p. 324-333. Citado 2 vezes nas páginas 76 e 154 .

RUSSOLO, L. The Art of Noises. New York: Pendragon Press, 1986. Citado 3 vezes nas páginas 29, 30 e 39 .

SACHS, C. The History of Musical Instruments. New York: W. W. Norton \& Company, Inc., 1940. Citado 4 vezes nas páginas 26, 28, 148 e 149.

SALTER, C. Entangled: Technology and the Transformation of Performance. Cambridge: The MIT Press, 2010. Citado 2 vezes nas páginas 53 e 66.

SCARASSATI, M. A. F. Walter Smetak: O alquimista dos sons. São Paulo: Perspectiva, 2008. Citado 12 vezes nas páginas 24, 35, 36, 37, 38, 39, 47, 69, 77, 93, 113 e 114.

SCARASSATI, M. A. F. Instrumentarium: dispositivos e contradispositivos no instrumentário brasileiro nos últimos 100 anos. In: COELHO, J. M. (Ed.). Cem anos de música no Brasil: 1912-2012. São Paulo: Andreato Comunicação e Cultura, 2015. Citado 9 vezes nas páginas 36, 69, 77, 86, 87, 96, 105, 113 e 219.

SILVEIRA, H.; MUNIZ, M. Tábua mobile, a musical instrument designed for multimedia performance. In: 18th International Congress on Sound and Vibration Proceedings. Rio de Janeiro: International Institute of Acoustics and Vibration, 2011. Citado na página 97.

SILVEIRA, H.; NUNZIO, M. D. Ibrasotope: um ano. Ibrasotope [RT01], p. 4 - 11, 2008. Citado 3 vezes nas páginas 78, 79 e 82.

SIMONTON JR., J. The drummer boy: Rhythm accompaniment for music. Popular Electronics, v. 35, n. 1, p. 25-40, 97, July 1971. Citado 2 vezes nas páginas 132 e 133.

SINZIG, F. P. Luthier. In: Dicionário Musical. 2. ed. Rio de Janeiro: Livraria Kosmos Editora, 1959. Citado na página 24. 
SMETAK, W. Simbologia dos instrumentos. Salvador: Associação dos Amigos de Smetak, 2001. Citado 3 vezes nas páginas 36, 38 e 39.

SMETAK, W. Smetak Imprevisto - Catálogo de Exposição. São Paulo: Museu de Arte Moderna de São Paulo, 2008. Citado na página 38.

STERNE, J. Out with the trash: On the future of newmedia. In: ACLAND, C. R. (Ed.). Residual Media. Minneapolis: University of Minnesota Press, 2007. cap. 2, p. 16-31.

Citado 2 vezes nas páginas 47 e 48.

TANCOCK, J. The influence of marcel duchamp. In: D'HARNONCOURT, A.; MCSHINE, K. (Ed.). Marcel Duchamp. New York: The Museum of Modern Art / The Philadelphia Museum of Art, 1973. cap. The Influence of Marcel Duchamp, p. 159-178. Citado na página 44.

THÉBERGE, P. Any Sound You Can Imagine: Making Music/Consuming Technology. Middletown: Wesleyan University Press, 1997. Citado 9 vezes nas páginas 54, 55, 56, 57, $65,74,146,148$ e 152 .

TRAGTENBERG, J. N. Instrumentos digitais de dança e música: uma proposta de paradigma para potencializar o design de instrumentos para expressão musical e corporal. Dissertação (Mestrado) — Universidade Federal de Pernambuco, Recife, 2018. Citado na página 110.

TRAGTEnBERG, L. Artigos Musicais. São Paulo: Perspectiva, 1991. Citado na página 35.

VALE, A. J. V. (Ed.). Industrial Culture Handbook. San Francisco: RE/Search, 1983. Citado 3 vezes nas páginas 48, 49 e 50 .

WAISVISZ, M. Cracklebox. 2004. Disponível em: < http://www.crackle.org/CrackleBox. htm $>$. Citado 2 vezes nas páginas 60 e 61.

WEBER, M. From Max Weber: Essays in Sociology. [S.l.]: Routledge, 1991. Citado na página 145.

WEBER, M. Os fundamentos racionais e sociológicos da música. São Paulo: EDUSP, 1995. Citado 3 vezes nas páginas 145, 146 e 148. 

Apêndices 



\section{APÊNDICE A - Levantamento de produção - Tony da Gatorra}

\section{A.1 Instrumentos}

\section{Gatorras}

Protótipo - Gatorra no $\mathbf{1}^{\mathbf{1}}$ Primeiro protótipo da Gatorra, construído entre 1994 e 1998 com corpo de madeira, com tampo de fórmica branca e azul claro.

Gatorra $\mathbf{n}^{\mathbf{0}} \mathbf{2}$ Também chamada de Gatorra Baixo $\mathbf{n}^{\mathbf{0}} \mathbf{2}$, foi construída a partir da experiência da Gatorra $\mathrm{n}^{\circ} 1$. Já é feita com um perfil de alumínio e sua cor predominante é o vermelho. Foi inicialmente construída para ser usada pelo próprio Tony, mas vendida para Binho Miranda durante uma gravação do programa Raul Gil.

Gatorra n⿳3 Guilherme Barrella.

Gatorra $\mathbf{n}^{\mathbf{0}} \mathbf{4}$ Bruno Ramos.

Gatorra n5 Luísa Lovefoxxx, vocalista da banda Cansei de Ser Sexy, provavelmente em 2006, com fórmica lilás. Para numeração: < http://tonydagatorra.blogspot.com.br/ 2006/01/31106.html>. Acesso em 13 de junho de 2016.

Gatorra $\mathbf{n}^{\circ} \mathbf{6}$ Sérgio Pinto.

Gatorra $\mathbf{n}^{\mathbf{0}} \mathbf{7}$ Nick McCarthy, guitarrista da banda escocesa Franz Ferdinand, presenteada posteriormente para o músico Graeme Ronald. Feita em verde \& amarelo para representar as cores do Brasil, por ser um instrumento feito sob encomenda para um músico estrangeiro.

Gatorra $\mathbf{n}^{\mathbf{0} 8}$ Diogo da Gatorra. Primeira gatorra feita sob encomenda para um comprador do Rio Grande do Sul.

Gatorra $\mathbf{n}^{\circ} \mathbf{9}$ Não foi feita sob encomenda, Tony não se recorda se foi vendida em um show em Porto Alegre ou Curitiba.

Gatorra $\mathbf{n}^{\mathbf{0}} \mathbf{1 0}$

Gatorra n ${ }^{\circ} 11$

Gatorra $\mathbf{n}^{\mathbf{0}} \mathbf{1 2}$ Verde e amarela, 
Gatorra nº13 Encomendada por Eduardo Santos,

Gatorra $\mathbf{n}^{\circ} \mathbf{1 4}$ Gatorra com design transicional, com botoeiras de contato e sintonizador de TV, possivelmente a última a possuir este recurso. Houve tentativas de implementar um sistema de transmissão sem fio. Tampo em acrílico texturizado de cor grená e EVA preto.

Gatorra $\mathbf{n}^{\mathbf{0}} \mathbf{1 5}$ Gatorra com tampo inteiro feito em alumínio, sem cores, feita sob encomenda para o músico Paulo Beto.

Gatorras $\mathbf{n}^{\mathbf{0}} \mathbf{1 6}$ e 17 Entre as gatorras 15 e 18 há um conflito de dados sobre as gatorras produzidas. Há 3 gatorras feitas neste intervalo, uma delas foi vendida em leilão no show realizado na Casa do Mancha em São Paulo, outras duas foram feitas sob encomenda, para o produtor Alê Fonseca, de Belo Horizonte, e para o músico Marcelo Conter, de Porto Alegre.

Gatorra $\mathbf{n}^{\mathbf{0}} \mathbf{1 8}$ Feita sob encomenda para Arthur Joly, mas vendida para o músico Paulo Abraão. Possui um circuito de Atari Punk Console embutido.

Gatorra $\mathbf{n}^{\mathbf{0}} \mathbf{1 9}$ Feita sob encomenda para o autor, para canhoto.

Gatorra $\mathbf{n}^{\mathbf{0}} \mathbf{2 0}$ Arthur Joly

Gatorra $\mathbf{n}^{\mathbf{0}} \mathbf{2 1}$ Marcelo Birck. Feita sob encomenda com acabamento transparente no corpo, iniciando uma série de Gatorras feitas com o corpo em policarbonato

Gatorra Aquárius Instrumento construído a priori para ser a Gatorra de número 20, modificado posteriormente em um instrumento com dois braços, a partir da inclusão de um batucador como segundo braço.

\section{Gatorra $n^{\circ} 22$}

\section{Gatorra $n^{\circ} 23$}

\section{Gatorra $n^{\circ} 24$}

Gatorra $\mathbf{n}^{\mathbf{0}} \mathbf{2 5}$ Design diferente, mudanças no braço e no tamanho do corpo

\section{Gatorra $n^{0} 26$}

Gatorra $\mathbf{n}^{\mathbf{0}} \mathbf{2 7}$ Feita sob encomenda para o autor, para canhoto, com tampos e perfil de acríico. 


\section{Minigatorras e batucadores}

Minigatorra $\mathbf{n}^{\circ} \mathbf{1}$ Vendida a um amigo de Porto Alegre

Minigatorra $\mathrm{n}^{\mathrm{0}} \mathbf{2}$ Feita sob encomenda para a compositora Lulina

Minigatorra $\mathrm{n}^{\circ} \mathbf{6}$ Vendida durante a gravação do programa Matador de Passarinho

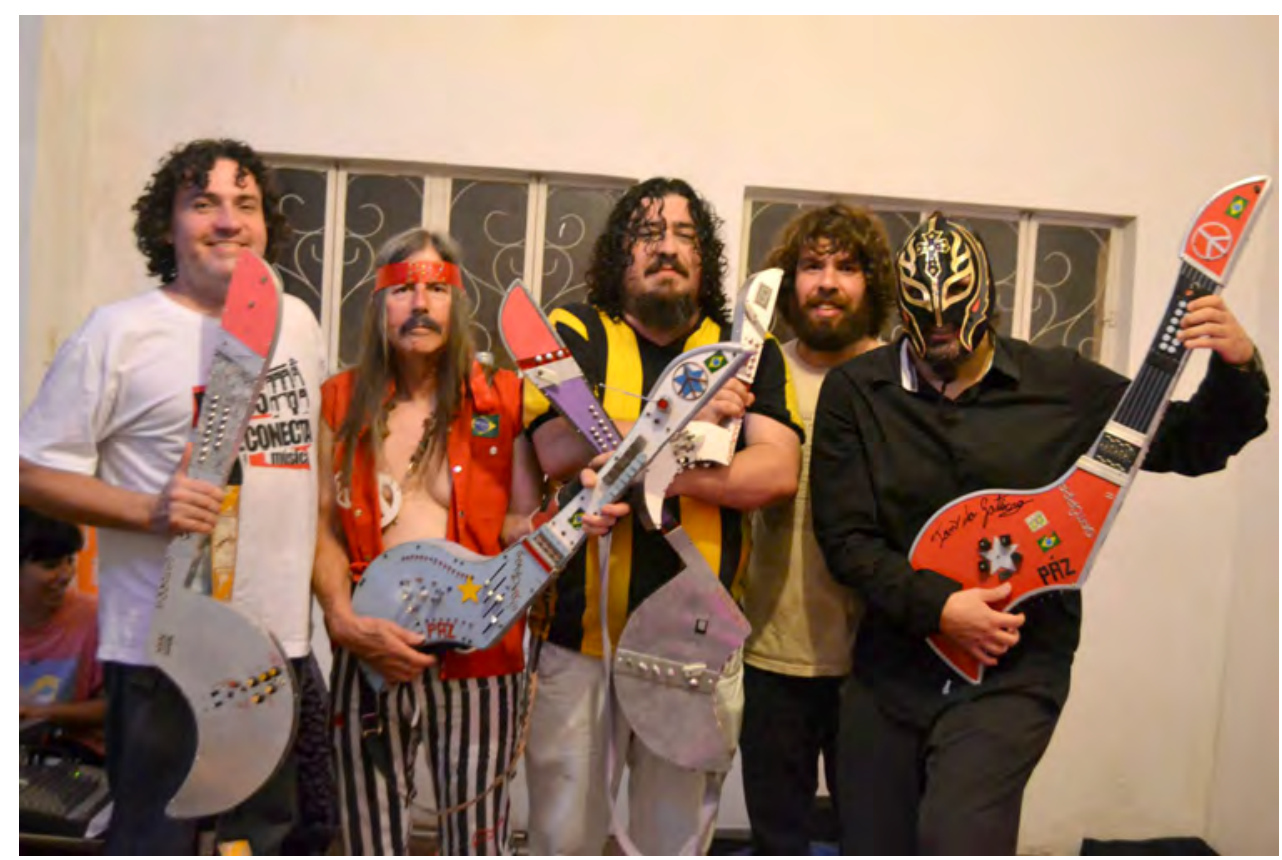

Figura 46 - Da esquerda para a direita: O autor com a gatorra $\mathrm{n}^{\circ} 19$, Tony com a gatorra $\mathrm{n}^{\circ} 1$, Paulo Abraão com a gatorra ${ }^{\circ} 18$ e a minigatorra ${ }^{\circ} 7$, Thiago Babalu e Alexandre Porres com a gatorra ${ }^{\circ} 2$. Foto: Acervo Alexandre Porres.no

\section{A.2 Discografia}

\section{Discos de Tony da Gatorra}

Paz pra ti Gravado em 1998, com seis faixas. Em alguns relatos, Tony se refere a este disco com o nome de "Paz e amor".

Só Protesto Gravado entre 1998 e 2004, com participação de outros artistas da cena musical Portoalegrense.

Só Protesto Relançamento pela Peligro, em 2005, contendo os dois primeiros discos de Tony gravados em Porto Alegre, lançado em parceria com o selo Open Field. Acredito que as . < https://www.youtube.com/playlist?list=PLg9IaBA_buO2XQH-oY2WG2id3b8lpSwpC 
Novos Pensamentos Lançado em 2008 pela gravadora independente Slag ${ }^{1}$

The Terror of Cosmic Loneliness Disco lançado em 2010 no Reino Unido, resultado da parceria com o músico galês Gruff Rhys, integrante da grupo Super Furry Animals ${ }^{2}$. $<$ https://www.youtube.com/playlist?list=PLg9IaBA_buO1dyQHkrq5B8x9cBydtSeeM>.

Paiz sem Lei Lançado em 2013 de forma independente por Tony da Gatorra.

Tony da Gatorra e os Ufonistas Lançado em 2014 pelo selo Recohead, resultado da parceria de Tony com os músicos Arthur Joly, Paulo Beto / Anvil FX, Eloi Silvestre e Akira S.

Extinção Single lançado em 2015.

Gomorra Lançado em 2016 em parceria com o músico gaúcho Tainam Dias.

O som da Gatorra Lançado em 2018, co-produzido com Tainam Dias, é o primeiro disco feito por Tony de músicas sem letra.

\section{Outros artistas}

Cristalina Primeiro disco lançado pela gravadora YB da compositora pernambucana Lulina, produzido por mim e por Maurício Tagliari. Diversas pessoas tocam gatorra em algumas das faixas. < https://www.youtube.com/playlist?list=PLCA5EE01B54FDDD98>

Rua B Música do grupo gaúcho The Gentrificators. Disponível em: <https://youtu. be/hNXCO-p652U>. Acesso em 08 de dezembro de 2016.

Remember Remember Grupo escocês do qual participa Graeme Ronald, atual dono da gatorra $\mathrm{n}^{\circ}$. Um relato de Ronald sobre seus instrumentos incomuns, incluindo-se aí a Gatorra, pode ser lido em < http://drownedinsound.com/news/4147862-planet-gear--remember-remem

1 Algumas fontes citam o ano de 2006 como ano de lançamento deste título. O lançamento, entretanto, só ocorre em Janeiro de 2008. Disponível em: <http://cenabeatnik.blogspot.com.br/2008/03/ publicidade-atrasada.html $>$. Acesso em 08 de dezembro de 2016.

2 Disponível em: <http://pitchfork.com/news/38315-gruff-rhys-preps-lp-with-tv-repair-man/>. Acesso em 08 de dezembro de 2016

3 Acesso em 6 de outubro de 2015 


\section{APÊNDICE B - Entrevistas}

\section{B.1 Construtores e artistas}

\section{B.1.1 Chris Carter}

O músico e construtor britânico de instrumentos Chris Carter é um dos fundadores do coletivo Throbbing Gristle em 1976. O grupo também contava com a participação de Peter "Sleazy" Christopherson, Cosey Fanni Tutti e Genesis P. Orrige, estes dois últimos artistas visuais e de performance. Entrevista realizada por e-mail em 24 de fevereiro de 2015.

Antes do Throbbing Gristle você costumava se apresentar sozinho com equipamentos que você mesmo contruiu ou modificou. Você poderia descrever como você estruturava sua performance e o seu setup para estas apresentações? É sabido que você tinha um interesse em eletrônica, mas a acessibilidade e o orçamento para comprar equipamentos aparentemente também desempenharam algum papel neste sentido.

Naquela época o fator primordial para decidir qual o equipamento para tocar ao vivo era a minha falta de orçamento. Meu setup era estruturado ao redor de um sintetizador modular que eu mesmo construí, vários processadores de efeito também construídos por mim e alguns delays de fita comerciais, mas que eu submeti a algumas modificações. A maioria das minhas performances solo possuiam pouca estruturação formal, havia algumas 'seções' distintas que se relacionavam de algum modo com os filmes em Super 8 que eu e John Lacey preparávamos de antemão, mas o show era basicamente improvisado dentro do limite de uma hora.

No processo de modificar o circuito de pedal de guitarra em direção ao que veio a ser o Gristleizer, o que lhe direcionou? O que fez com que você 'parasse' em determinados pontos e 'congelasse' seu design?

Alguns dos meus primeiros protótipos do Gristleizer eram mais sofisticados e possuíam mais recursos, controles adicionais e um tamanho maior. Inicialmente eu decidi fazer pelo menos seis unidades para o Throbbing Gristle (o que acabou sendo um número maior), mas eu tinha um orçamento relativamente limitado para gastar com componentes e peças, e incluir todos estes recursos adicionais significava que a unidade 
precisaria de uma fonte externa de energia, pois as baterias não duravam o suficiente para uma apresentação completa do TG, com uma hora de duração. Por fim eu optei por um projeto mais básico, principalmente para manter os custos de produção mais baixos.

Afirma-se que o Gristleizer é fundamental para o som do Throbbing Gristle, você poderia descrever do ponto de vista do construtor o que, no projeto original, poderia ser responsável por isso?

Eu não concordo completamente com essa interpretação. Sem dúvida naquela época nenhuma outra banda usava algo parecido com o Gristleizer ao vivo, particularmente em vários instrumentos e vozes ao mesmo tempo. Mas há várias faixas icônicas do TG que não empregam o Gristleizer em absoluto. O 'som' do TG vem da combinação de muitos elementos diferentes, e o Gristleizer é apenas um deles.

No tocante ao conhecimento técnico, você possui uma formação bem diferente em relação aos demais membros do TG, com exceção de Peter Christopherson. Como era a dinâmica entre o ímpeto estético do grupo - baseado em seu passado nas artes visuais e performáticas - e sua contribuição técnica?

Acredito que Peter e eu éramos as cabeças 'criativas tecnicamente' no grupo, enquanto Cosey e Genesis eram 'criativas expressivamente'. Em relação ao aspecto de performance do TG, acredito que Peter possuía uma abordagem mais teórica e conceitual, eu era mais prático. Ambos tínhamos ideias e conceitos para instrumentos, técnicas de produção e assim por diante, mas eu era o único membro do grupo capaz de construir fisicamente aqueles equipamentos. Embora eu tenha sido completamente auto-didata desde muito cedo, eu era capaz de construir e desenvolver instrumentos eletrônicos e eletroacústicos, e processadores de efeito, relativamente complexos.

Já a estética visual era um pouco diferente. Enquanto grupo nós compartilhávamos designs, conceitos, peças gráficas, logos, etc. e eu executava estes projetos em caneta e tinta, e Peter os traduzia em fotos e fotolitos para impressão. Seu talento principal neste sentido era como fotógrafo e criador e layouts. Cosey e Genesis eram excepcionais em colagens e experimentações visuais, como pode ser visto nos primeiros cartazes e malas-diretas do Throbbing Gristle.

Você poderia comentar a respeito da sua colaboração com o Dirty Electronics Ensemble e com Cerith Wyn Evans?

John Richards, do DEE, me procurou há alguns anos para fazer o design e colaborar em um sintetizador portátil feito uma placa de circuito impresso. O resultado foi o Dirty 
Carter Experimental Sound Generator.. Em seguida fizemos algumas oficinas de DIY no Reino Unido e no STEIM em Amsterdam, e também algumas apresentações ao vivo. Eu recentemente criei uma faixa usando o novo Dirty Electronics Mute Synth $\boldsymbol{I I}$, o sintetizador e o CD podem ser comprados diretamente da Mute Records.

Nós somos amigos de Cerith Wyn Evans há muitos anos, e já faz algum tempo que vínhamos conversando sobre colaborar de alguma forma. Aconteceu finalmente através do nosso empresário, Paul Smith, que descobriu uns alto-falantes estranhos, planos e muito direcionais, feitos nos EUA. O TG ia usar estes falantes na nossa performance no Tate Modern em 2007, mas descobrimos que os falantes não eram poderosos o suficiente para nossa apresentação no Turbine Hall. Então nós (Cerith, eu, Cosey e Peter) criamos $\mathrm{A}=\mathrm{P}=\mathrm{P}=\mathrm{A}=\mathrm{R}=\mathrm{I}=\mathrm{T}=\mathrm{I}=\mathrm{O}=\mathrm{N}$ usando múltiplos falantes, cada qual gerando um som semialeatório diferente. Gravamos Genesis lendo alguns poemas de Cerith e incorporamos isso em nosso esquema multicanal. O resto, como dizem, é história. Você pode ler um pouco mais sobre esta colaboração no nosso site: <http://www.throbbing-gristle.com/ tg-files/apparition.html>.

\section{B.1.2 Scott Lee - PAiA Electronics}

Scott Lee é coordenador do suporte e assistência da PAiA Electronics atualmente. Entrevista realizada por e-mail no dia 18 de janeiro de 2018

Em que período que a PAiA vendeu a Drummer Boy? Você pode estimar quando a produção e a distribuição começou e se encerrou?

O modelo 7701, Drummer Boy, fez parte do catálogo da PAiA de 1971 a 1976. Kits foram produzidos até 1978, mais ou menos.

Já houve um kit só para o gerador de sons do Drummer Boy, ou ele só foi vendido como um todo? No artigo de 1971 há uma imagem de um "Percussion Pac", descrito como o gerador de sons do Drummer Boy para ser tocado com as mãos, mas eu não encontrei outras referências a este projeto em outros lugares.

O Percussion Pac, modelo 1071, fez parte do catálogo de 1971. Era o gerador de sons do Drummer Boy com botões para ativar os sons percussivos.

Parte da minha pesquisa lida com o modo como certos projetos são recriados ou clonados em outros lugares, diferentes daqueles da sua versão original, e com a forma como músicos e construtores de instrumento fazem música com estes projetos. Há, por exemplo, uma bateria eletrônica tocada com os dedos que foi muito popular no Brasil nos anos 1980 e 1990, e cujo princípio de operação é muito semelhante ao projeto da Drummer Boy. Minha pergunta é, na PAiA vocês tomaram conhecimento deste desenvolvimento em outros lugares? Eu sei que artigos como os da Popular Electronics cruzaram o mundo, mas 
vocês chegaram a ter contato com outros projetos que possam ter sido influenciados pelas criações da PAiA?

Os sons percussivos da Drummer Boy são resultado de um circuito de oscilador duplo-T amortecido, recebendo um pulso. Esta foi a base da maior parte dos sons percussivos eletrônicos anteriores ao advento da amostragem digital ou da reprodução a partir de wavetables, então é bem provável que muitos dispositivos dessa época utilizem circuitos semelhantes para gerar sons. O precursor do 7701, por apenas alguns anos, foi o kit da Thumpa-Thumpa Box, que não possuía padrões de ritmo mas tinha algumas variáveis no seu padrão de repetição. O kit 3750, Programmable Drum Set, sucedeu o 7701 e foi oferecido entre 1978 e 1986, e neste kit todo o circuito de geração de sons, memória e controle por toque ocupavam uma única placa de circuito impresso. Nossa oferta atual utilizando circuitos com oscilador amortecido, o 9302 Drum Tone Board, foi introduzido em 1993. Um equipamento autônomo, operado por um pad, chamado Audio ThumDrum, foi disponibilizado por um curto período, mas sua produção foi interrompida devido ao alto custo de produção associado í s baixas vendas. O 9302 pode ser alojado em uma caixa de montagem junto com o kit 9212 Proc Amp para ser acionado por meio de pads, ou junto com o kit 9700 MIDI2CV8, para ser acionado por notas MIDI.

\section{B.1.3 George Romano}

George Romano é técnico em eletrônica, projetista e mencionado por alguns autores como sendo o criador do protótipo da bateria eletrônica SLICIE. Entrevista realizada por telefone em $1^{\circ}$ de fevereiro de 2018

\section{Atravéz do Eric Marke eu fiquei sabendo que você desenvolveu o projeto daquela bateria de dedo}

É, teve essa bateria que eu fiz, mas fiz só o projeto, não fabriquei. Aqueles sons dela eu ouço isso até hoje, são os mesmos timbres dessa bateria lá daquela época, outro dia mesmo eu ouvi na rua uma música tocando, eram aqueles sons, as pessoas tem um trabalhão pra fazer no digital o que é uma coisa muito simples. Essa bateria foi o seguinte, eu tava desenvolvendo um ritmo pra um órgão, tinha um ritmo que o módulo original era analógico e era uma coisa muito complexa, e eu fiz um projeto baseado num sequencer que já existia, usando CMOS, não lembro qual era a marca. Eu estava fazendo esse ritmo, não lembro se era pra Gambitt, porque eu trabalhei lá mas tive fábrica, também, tive três fábricas, teve a Audac, que fazia órgãos litúrgicos, teve a Eminence, fazia muita assistência também de sintetizador, o Moog, ARP, Prophet 5, Synclavier.

Aí essa bateria, eu tava montando os sons numa matriz de contato, e por acidente eu esbarrei ali e tocou um som. Daí veio a ideia de usar umas chapinhas pra fazer contato e tocar. Isso aí ia virar vários produtos, um produto era pra ser colocado no painel do 
órgão, um outro era o independente com sequencer, e depois foi feita a caixinha pra ser tocada com os dedos. Os sons desse projeto usavam esse oscilador do tipo duplo T, que chamam, que pode ser feito com transistor, com operacional, pode ser feito com CMOS. Isso aí é simples, se você entrar no Datasheet dos integrados, ele tem as aplicações do chip, ele tem um receituário das coisas que você pode fazer com ele. Eu não lembro se eu vi isso num livro da Fairchild, tinha essas enciclopédias eletrônicas, que a gente pegava, né? Esse circuito é uma besteira, é muito simples, o trabalho que você tem num circuito desses é achar a frequência do bumbo, a duração, essas coisas, o circuito mesmo é simples.

\section{Eu vejo que hoje em dia tem uma demanda de mercado pra esses pro- jetos analógicos...}

Isso, isso, no mercado hoje, né? Nós estamos falando do que hoje é mercado de massa, de consumo, e o que é mercado mais específico, feito sob encomenda, quando uma pessoa gosta de um produto, né? Existe realmente um mercado, até pra essa bateria. Existe alguém que vai comprar, eu hoje eu vejo a evolução dos produtos chineses, o que eles produzem hoje é muita coisa, mas muita coisa. E você vê que dentro dos produtos deles tem produtos que na realidade são essas coisas aí, são produtos pra alguém consumir, mas não em massa. Tem mercado, mercado pra qualquer tipo de produto, principalmente instrumento musical que seja, até órgão eletrônico [ainda] se fabrica hoje, falaram "ah, não vai fazer mais, porque o pessoal só vai tocar sintetizador, não é?". A tendência, existem duas tendências né? Existe uma tendência daquela pessoa que é profissional e quer ganhar dinheiro, então ele quer ser prático, o que ser prático na área da música hoje? Ser prático ele vai pegar um computador, um palmtop, um laptop, o que for, vai instalar um software de edição de música e vai colocar uns vst, uns vsti, vai arrumar um teclado MIDI e vai fazer sua música e ganhar dinheiro. Ele não quer mais ficar montando sequências na mão, em teclado, ele não quer mais isso. Porque normalmente a produção era feita em sequenciador na mão mesmo, nos teclados, hoje o cara tem software aí que rapidinho ele resolve isso.

Então a tendência, uma é essa, é a tendência do profissional que quer ser rápido e quer ganhar dinheiro, ele não vai usar esse tipo de produto porque ele tem tudo isso em vsti, tudo existe em vst e vsti. E tem aquele que realmente quer sentir o som, quer ver o instrumento, né, você vai ver hoje em baterias eletrônicas de palco, você vê que tem baterias eletrônicas que são perfeitas de timbre, na simulação de uma bateria acústica, mas a preferência ainda é uma bateria acústica, você pode ver. São poucos que colocam uma bateria digital no palco, são poucos. Porque ainda não deu, não chegou ainda, alguns instrumentos como o piano, é impossível você fazer um piano eletrônico que dê a qualidade de um piano acústico, é impossível. Quer ver, órgão de tubo, órgão de tubo não dá essas coisas que eles fazem aí, não tem como, é físico, é geração física, e aí vai, né?

\section{Você chegou a dar ideia pro nome da SLICIE também?}

O único nome que eu tava fazendo um produto, eu tava fazendo um produto, e eu 
pus o nome de Octapad, que já era um sensorzinho de piezo, o pessoal da Roland do Brasil na época, lá, um dos diretores, pegou esse nome, e viu eu falando e levou lá pro Japão e a Roland fabricou. É, a Roland usou só o nome e a ideia, né, que era um quadrado, na verdade um retângulo, que tinha uns pads que você tocava vários sons ali com a baqueta. Eu fiz um protótipo na época, que isso já tinha dinâmica inclusive, esse outro instrumento (a slicie) aí ele não tinha dinâmica, ele toca sempre no mesmo volume, não importa, eu já tinha feito esse com dinâmica.

\section{Você lembra em que ano foi isso?}

Eu acho que foi 70, eu vou tentar lembrar aqui. Eu tou lembrando de onde eu tava em 70, eu tava na federal eu fazia federal em São Paulo, eu tava na Federal, eu tava estudando e já fazia uns bicos em fábrica. Como eu ia tocar em algumas bandas na época, eu fazia minhas coisas, o órgão elétrico, tudo eu fiz pra mim pro meu uso, né? Eu não tou lembrando, eu vou tentar descobrir, que tem uma história aqui da Gambitt, fundação da Gambitt, a primeira, porque a Gambitt teve três fábricas, eu vou tentar descobrir, eu acho que eu devo ter isso em algum lugar. É porque muitos registros não eram digitais, né? A gente não tinha registro digital, era tudo papel.

\section{Você estudou eletrônica na Federal?}

A Federal quando na época eu estudei era na Rua Apa, lá na Santa Cecília, além da Federal ali era Ministério da Educação, alguma coisa assim. Lá eu fiz um curso conjugado, era eletrotécnica e mectec, depois uma engenharia operacional que não deu certo lá. Mectec era mecânica e elétrica, e eu fiz também lá na época, esse curso vinha junto. Na Federal você tinha que estudar tudo, aquilo ali era uma encrenca, você tinha que fazer mecânica, eletrônica, o que tinha ali tinha que fazer. Aí depois eu cheguei a fazer três anos lá, que não deu certo, era uma engenharia operacional de três anos que não saiu, não homologou. Aí eu não fiz mais nada, tudo que eu estudei aí foi eu mesmo, tudo que eu estudei de eletrônica digital, tudo foi por minha conta.

Antes da escola eu já mexia, eu comecei a me interessar, só pra você ter uma ideia, com o Theremim, isso já foi em 64, isso eu me lembro. Lembra o Theremin, aquele negócio que você punha a mão, então, eu já me interessava por causa do Theremin, aí eu comecei a mexer, minha iniciação em eletrônica foi por causa disso aí. O theremim foi o seguinte, eu fui fazer um curso de eletrônica básica, não sei se era instituto Aladim, instituto Edison, acho que era Instituto Edison, e lá na inscrição tinha várias coisas que eram feitas, né, de eletrônica, acho que era pra incentivar aluno, né? Aí tinha uma onça [risos], uma onça rajada, você chegava a mão perto dela, e além dela acender os dois olhos dela, tinha duas lampadinhas, ela fazia aquele miado, aquele som do theremin. Eu falei, nossa, que coisa interessante isso aqui.

Uma onça empalhada? Era uma onça parda, que ficava em cima da mesa, uma 
oncinha parda, que você ia chegando com a mão perto da cabeça dela, e ela além de fazer o som, aquilo é um som fajuto de onça, os dois olhos acendiam, né? Aí comecei a investigar o que era aquilo, aí eu descobri que era o princípio básico do theremin, que eram dois osciladores, o batimento deles sai uma frequência baixa.

Você chegou a fazer theremins? Eu fiz alguns, na época, mas não tinha aplicação musical, era mais uma coisa interessante. Porque ele não tem precisão de nota, né?

\section{Hoje em dia tem bastante gente fazendo...}

Mas é que hoje, hoje veja bem, se desenvolveu, dentro até do esporte, tudo, se desenvolveram modalidades que, quando eu era criança a gente andava de carrinho de rolimã, hoje o cara pega o carrinho de rolimã ele voa, pula, é a diferença, né? Houve uma evolução de tudo, né, então é diferente, hoje o cara consegue tocar um theremin, inclusive você consegue fazer ele mais preciso, você consegue estabilidade no oscilador, principalmente no fixo, antigamente era tudo com válvula.

\section{Então a partir desse interesse pelo Theremin você resolveu fazer curso de eletrônica?}

Eu fiz vários cursos de eletrônica, antes mesmo de eu entrar na Federal eu fiz o Aladim, que era um curso, fiz o Instituto Edison, era na Rua da Consolação. É antigo, tinha bonde, eu subia a rua da Consolação de bonde, tem uma noção, então faz tempo isso. Aquela eletrônica ali na época, tava começando a aparecer os primeiros transistores, era válvula, era tudo à base de válvula. Inclusive depois que eu terminei esse curso eu comecei a consertar muito amplificador Celpa, Giannini, valvulado, e modificando eles. Isso era uma coisa que eu fazia, modificava pra melhorar, fuçar, inventar, coisas do tipo.

\section{Você também tocava?}

Toquei um tempo, eu toquei teclado um tempo, eu nunca fui um profissional da área, eu não tinha paciência de tocar porque eu não decorava a música e tinha que ficar escrevendo tudo em cifra, eu falei "ah, eu não vou ficar tocando mais isso aqui". Eu tenho, os instrumentos, muitos eu tenho até hoje, eu tenho um set muito grande de instrumentos, eu tenho um TX-70 eu tenho ainda ele, que era um protótipo de um sintetizador da Gambitt, os outros teclados que eu tenho são teclados normais, né? Os que eu fiz, né, não ficou nenhum. Na Federal tinha um problema que chegou uma época, como os professores, a maioria deles era da Eletropaulo, outro trabalhava não sei aonde, então os horários começaram a ficar assim, eu tinha uma aula de manhã, aí eu tinha uma outra aula à tarde, então eu tinha que tocar pra poder ganhar algum dinheiro, senão não tinha jeito. Não tinha como arrumar um emprego, os horários lá ficaram assim.

Eu cheguei a trabalhar, antes da Gambitt, com uma pessoa que chamava Sidney Paretti, a gente clonava o piano Fender, aquele primeiro Fender acústico com agulhas, e o 
clarinete Hohner, a gente clonava eles aqui, fazia umas cópias. O nome que ele punha nos instrumentos era Yendis, com Y. Hoje eu não sei se o pessoal conseguiria na realidade tocar esses instrumentos, pegar a mesma habilidade. O pessoal não tinha muito recurso, o piano Fender eu lembro que era muito caro, o teclado era feito por um polonês lá em Curitiba, ele que fazia o teclado, ele trabalhava numa fábrica de pianos, não era a Essenfelder, era outra.

\section{E na época tinha mercado pro piano Yendis?}

Tinha, esse piano tinha, tinha porque o piano era muito caro e ele ficou muito parecido. O Suette veio junto, o Suette era do Três no Rio, do irmão de um deles. Essa época é 70, agora eu já me achei, daí que eu fui pra Gambitt, fui pra Gambitt porque a gente tava fazendo uma Leslie, na época, lembra da Leslie? E o pessoal da Gambitt encomendou essa Leslie pra colocar nos órgãos, motor e tudo, e aí eu fiquei lá. Aí eu vi que eles precisavam de ritmo, precisavam de algumas coisas, eu acabei ficando lá, foi por volta de 70. Então essa caixinha de ritmo, foi depois, deve ter sido anos 80, viu, 75, por aí. Eu não se eu tinha esse projeto antes, mas é por aí, 70 a 80, esse período de 10 anos aí.

\section{E como foi que ela foi fabricada?}

Aí eu tava lá na Casa Verde, eu tinha uma fábrica pequena. Eu não lembro como foi a história, veio alguém, eu não lembro se veio o pessoal da Meteoro, do Zé, eu tava lá, falei "Ó, toma isso pra você", eu dei. Eu dei uma caixinha, um prototipozinho, eu me lembro que eu dei, e aí foi. Aí apareceu na Santa Ifigênia, eu acho que ele mexeu, não deve ter sido exatamente o que eu fiz, tinha um monte, qualquer porta de loja tinha um cara tocando isso aí.

\section{E aí vendeu? Como foi?}

É, vendeu muito, é uma coisa interessante, né, não tinha nada na época à disposição, tão prático, né?

\section{B.1.4 Loop B}

Loop B é músico e toca com diversos tipos de sucata. Foi um dos pioneiros do gênero industrial no Brasil. Entrevista realizada por e-mail em 3 de março de 2018.

Você menciona que seu interesse pela sucata como fonte sonora é uma coisa que vem desde a adolescência, você poderia falar um pouco mais sobre isso?

Eu não diria que havia um interesse específico pela sucata, mas a busca por timbres diferenciados acabavam por me levar a usar objetos sonoros variados. Está um pouco perdido na memória mas me recordo que por volta dos 20 anos de idade meu set de percussão tinha pelo menos dois objetos que não eram instrumentos musicais convencionais: 
uma bala de canhão e um brinquedo sonoro para bebê.

Como era esse uso da sucata como percussão no Lendas e no Kumbai Nidada? Existe algum tipo de registro disso?

No Lendas eu trabalhava com cítara, teclado e percussão, e a percussão com sucata não tinha ainda uma atenção especial, o foco era mais no resultado sonoro: a música experimental. Desse trabalho tenho registro em muitas fitas cassete. No Kumbai Nidada sim, foi desenvolvida uma pesquisa nessa linha, junto aos outros músicos da banda - Teo Ponciano e Anjo Flores, principalmente com o Teo que era percussionista como eu. Desta época saiu a máquina de lavar. Quando o Kumbai acabou, eu segui solo e radicalizei a pesquisa, deixando em segundo plano a percussão em instrumentos convencionais. Do Kumbai eu tenho também muito material registrado em fitas cassete, mas com melhor qualidade, com equipamentos de 4 pistas: Fostex e Tascam. E também registros em vídeo VHS. Também entramos em estúdio uma vez e gravamos uma demo com 3 músicas. Tenho o registro disso já mixado.

Você menciona uma influência da música eletroacústica no seu trabalho, relacionada com uma viagem à França. Como foi esse contato?

Eu 81 eu fui morar na França, mas já conhecia alguns compositores de música eletroacústica antes disso. Nos anos 70 comprei num sebo um vinil, que havia sido lançado anos antes no Brasil, com músicas de um festival de música eletroacústica ${ }^{1}$. Eu também tinha o vinil do Jorge Antunes. E tentei fazer um curso com o compositor Conrado Silva em São Paulo, curso que não aconteceu devido à pouca quantidade de alunos. Provavelmente eu conhecia alguns outros trabalhos, mas não me recordo. Em Paris eu tive bastante contato com José Augusto Mannis, que já vivia lá e estudava no Conservatoire National Supérieur de Musique et de Danse. Eu participei de algumas aulas com ele, como aluno ouvinte. Conheci várias obras, me recordo particularmente de uma obra de música concreta de Iannis Xenakis que me marcou muito, sobretudo me abriu horizontes para o ruído. Os professores faziam análises aprofundadas, enfim, foi uma ótima vivência. Depois novamente em São Paulo fiz alguns cursos com Conrado Silva que sem dúvida me ajudaram a ser o músico que sou hoje.

Como é o seu processo de pesquisa destas fontes sonoras de sucata? Como você determina o que entra ou não no seu repertório?

A pesquisa acontece de duas formas que se entrelaçam, que interagem: uma intencional e outra fundamentada no acaso. Por exemplo: eu me senti limitado a timbres metálicos e comecei a procurar outros timbres usando materiais plásticos. Na mesma época encontrei na rua pedaços de isopor e gavetas de armário de madeira. Pronto, juntou a fome com a vontade de comer! O acaso é muito presente na minha pesquisa. Outro

1 Disponível em: https://www.discogs.com/Various-Electronic-Music-Vol-V/release/553290. Acesso em 24 de maio de 2018. 
exemplo: um amigo de meu sobrinho tinha um cone de segurança de estrada, não sei como conseguiu, talvez tenha roubado de algum lugar. Ele teve que se livrar do cone e deu para o meu sobrinho. Um amigo nosso estava numa festa na casa de meu sobrinho e começou a batucar no cone. Meu sobrinho viu, achou legal e pensou que eu poderia fazer algo interessante com aquilo. E realmente o cone se tornou um dos grandes instrumentos que uso atualmente, com um grave maravilhoso, e nem fui eu que descobri que dava para tirar som dele. Claro que quando caiu na minha mão eu fui experimentando de várias formas e ampliando as possibilidades sonoras e cênicas do objeto. Esse lado cênico, da performance, também é determinante para ter um objeto em meu repertório ou não. Retomando sua pergunta: quando encontro algo eu fico tocando, tocando e tocando, explorando de várias formas o objeto. Outro momento é a integração com a eletrônica. Em primeiro lugar, eu crio a parte eletrônica. Depois é que vou experimentar os objetos e definir o que "combina" melhor. Isso passa também por aspectos concretos: espaço no palco, tempo de montagem e passagem de som, se vou de carro ou de avião, enfim, são muitos fatores determinantes.

Que outras influências você considera como importantes neste aspecto do teu trabalho?

Na pesquisa com sucata o contato com a obra de Hermeto Paschoal foi importante. $\mathrm{Eu}$ assistia shows dele, via suas performances nos festivais de música na TV, tocando chaleira, porco, enfim, a liberdade dele, o conceito de que tudo é música. Einstuerzende Neubauten também é uma banda que me marcou muito. Quando assisti um vídeo deles pela primeira vez, tocando num espaço que parecia uma fábrica abandonada, detonando enormes tubos de metal, batendo com pesadas marretas, enfim, foi um momento que minha alma musical se sentiu feliz e isso sem dúvida determina de forma firme, forte e até insconsciente o futuro caminho.

\section{Que outras pessoas você conhece que desenvolvem algo semelhante?}

Teo Ponciano, tocávamos juntos no Kumbai Nidada e desenvolvemos juntos muitas coisas. Fernando Sardo, que constrói instrumentos usando sucata, bambu, madeira, tocamos juntos algumas vezes. O Robert Pepper da banda Pas Musique de Nova York, também pesquisa timbres e objetos inusitados. Toca, por exemplo, com uma vara de pescar. Toquei com a banda e em alguns concertos em Nova York. Estes são os mais próximos, com os quais tenho amizade inclusive. Gosto também de Adriano Castelo Branco, um construtor bastante criativo. Existem vários outros, mas sem dúvida nenhum deles faz algo semelhante ao outro, porque cada um destes trabalhos é muito pessoal, com histórias particulares. O que existe é uma iconoclastia inerente a todos, sem ela estes trabalhos não seriam possíveis, jamais aconteceriam. 


\section{B.1.5 Cadós Sanchez}

Cadós Sanches é artista plástico e construtor de instrumentos, trabalhando também em parceria com Ruben Pagani e com o Brechó de Hostilidades Sonoras. Entrevista realizada por e-mail em 2 de março de 2018.

Como você descreveria o seu processo de construção, como ele começa e como você o desenvolve?

Comecei a fazer instrumentos quando dava aula de artes no ensino público de São Paulo por curiosidade, diversão e para usar em algumas oficinas de RAP que dava na época em uma ONG. Até hoje é a curiosidade e a diversão que movem meu processo de criação. No início utilizava os materiais que tinha em casa - shape de skate, roda de bicicleta - e neles esticava todo tipo de cordas, molas e objetos que achava sonoramente interessantes. Olhando em retrospectiva, acredito que essa fase inicial foi de pesquisa de materiais, sua resistência e formas de captação elétrica e amplificação acústica. Atualmente tenho encontrado alguns caminhos que desenvolvo de forma mais específica, mas que incluem tudo que já citei no início.

Um caminho que se aproxima da luteria tradicional são alguns instrumentos de cordas que comecei a desenvolver partindo de uma Torre criada pelo parceiro Ruben Pagani. Esses instrumentos têm formato cilíndrico e o cavalete acompanha seu formato, isso possibilita todas as cordas serem tocadas com o arco individualmente e, eventualmente, todas serem tocadas simultaneamente. As Torres tem uma diversidade de cordas (entre 16 e 8 cordas, dependendo da Torre), tenho uma com algumas das cordas mais graves do piano, cordas de baixo acústico, arames de piano e outros tipos, nessa utilizo captadores eletromagnéticos e piezoelétricos para amplificação, pois a Torre é de ferro e não tem uma boa ressonância acústica. Nas outras Torres que tenho feito busco formar uma espécie de família de cordas "incestuosa", pois utilizo um pouco de todos instrumentos de cordas que conheço. Tenho explorado o couro como superfície de ressonância e diversos materiais são utilizados como cordas. Para tocar esses instrumentos tenho feito alguns tipos de arco e pesquisado a gestualidade para a execução de cada um, principalmente na criação de camadas, texturas e efeitos com os diversos timbres, e em alguns casos microtons, que as cordas e sua afinação oferecem. Os instrumentos não tem afinação específica, disponho as cordas de forma empírica baseado na minha escuta e bagagens culturais, organizando os timbres e afinações conforme descubro formas de execução com o arco e outros objetos que utilizo no instrumento, como por exemplo motores com hélices ou uma agulha de crochê. Nessas torres tenho pesquisado também formas de ter uma certa mobilidade na tensão dessas cordas, desde cavaletes móveis até estandartes menos rígidos do que os dos instrumentos da família das cordas friccionadas clássicas ocidentais.

Outro caminho é o que estou voltando a chamar de "sonoramas". São instrumentos 
que utilizam interfaces diferentes dos instrumentos tradicionais. Um exemplo é a liga do tempo, uma roda de bicicleta com molas no lugar dos raios ligadas por captadores piezo elétricos e acionadas manualmente ou por motores com hélice, nesse instrumento tudo está conectado e ressoando simultaneamente, isso parece tornar toda tentativa de controle do instrumento em uma ação geradora de comportamentos inesperados. Claro que, com o domínio técnico das possibilidades de execução, os erros e comportamentos aleatórios diminuem, mas nunca desaparecem por completo. Outro exemplo de "sonorama" é um Pinball, jogo de fliperama que comecei a fazer já fazem uns 7 anos com Marcos Amâncio. Tenho montado esse sonorama com cordas, materiais percussivos, molas e objetos eletrônicos que são disparados pelo contato com a bola que percorre o circuito/pista. Nesse objeto vou deixar mais óbvia a ideia de jogo que acredito estar presente na execução de todos meus instrumentos e nas práticas que desenvolvo com eles. Os "sonoramas" tem infinitas possibilidades que são geradas pela captação disposta em toda a superfície, suas conexões físicas, seus acionamentos e controles de intensidade que geram diferentes nuances, combinações e respostas inesperadas e a impossibilidade da repetição de um gesto devido à mecânica ter uma relativa independência do corpo do jogador/tocador ou intérprete.

Por último, gostaria de falar do ISSR: interfaces sonoras em situação de rua. Comecei a desenvolver essa ideia por volta de 2011 também em parceria com Marcos Amâncio, nessa época a ideia era tocar em terrenos baldios, especialmente com os objetos que o lugar oferecesse, para isso, levávamos diversas baquetas, arcos e algumas superfícies que construímos que ajudavam a ressoar os objetos. Uma das superfícies que fiz era uma estrutura de tubos de PVC toda desmontável que servia como o suporte das teclas de um vibrafone, nela colocávamos os objetos encontrados no terreno como quem dispõe as teclas no xilofone ou vibrafone e improvisávamos com os sons dos objetos e do ambiente, não fazíamos registros disso. Recentemente utilizei os braços e motores que tocam a liga do tempo para tocar um piano abandonado em uma varanda de uma casa abandonada. O piano estava sem as teclas, martelos ou seja, sem seus maquinismos de percussão das cordas. Então levei meus próprios maquinismos para executar o piano que ainda tinha suas cordas e caixa de ressonância preservados, ainda soando. Essa ideia do ISSR é contínua, no entanto só acontece quando encontro nas minhas caminhadas pelas cidades algum tipo de situação ou objeto que me sugere uma interface sonora interessante, por isso, atualmente percebo que o ISSR vai mais ao encontro do que a rua me oferece, do que ao que eu posso oferecer pra ela, não são concertos com começo meio e fim ou algo do tipo em praça pública para um publico determinado.

\section{Como se deu o aprendizado das técnicas que você usa?}

Grande parte aprendo conversando com pessoas, todo tipo de construtor de instrumentos - profissionais, intrometidos e curiosos em geral -, serralheiros, marceneiros, vendedores de loja de suprimentos de eletrônica, mecânicos de automóveis ou catadores de 
ferro velho.

\section{Que nome você dá ao isso que você constrói?}

Alguns chamo de instrumentos musicais, sem problema em entrar em crise com construtores e músicos tradicionais, mas sabendo e deixando claro as diferenças entre luteria tradicional e experimental. Outros, como já disse, tenho chamado de "sonoramas", pois eles tem algumas questões de aleatoriedade, feedback, e jogo que não estão tão presentes nos outros instrumentos.

O que você ou outras pessoas fazem com estes objetos? Como você classificaria isso?

Fazemos sons, jogamos, brincamos e compomos com essas ações. Classifico como diversão.

\section{Algum destes projetos é mais representativo do seu trabalho?}

Todos projetos estão ligados pela pesquisa técnica de construção, acústica, amplificação e das práticas de execução, não acredito que algum tenha mais representatividade, mas gosto de pensar neles e em suas conexões com a rua ou espaço público de maneira geral, seja como possibilidade de execução em lugar público, como uma oficina em que levo algumas práticas para outros interessados, ou mesmo com os lugares e pessoas com que coletei os objetos para montar cada instrumento.

Você se considera influenciado na sua produção por outros artistas? Quais?

Dos artistas ocidentais (mesmo que não veja uma conexão direta com o que faço) lembro frequentemente de Jean Tinguely que conheci quando já estava intrometido nos motores e que matou boa parte da minha vontade de usar motores pra fazer som. Erik Satie é fantástico por seu bom humor, em tudo que leio e escuto dele me deixa claro que ele borra ou fica no limite - que não sei se existe, ao menos nas artes - entre diversão e profissionalismo. Jean Dubuffet me atrai pelas suas ideias sobre arte bruta, Akio Suzuki por suas sutilezas no uso dos materiais, Richard Wagner por seus escritos de 49, John Cage acho que leva ao extremo o trabalho de Satie, Paul Klee por alguns trabalhos que esteticamente muito me agradam e Cildo Meireles por ver em muitos de seus trabalhos uma junção de humor, conceito e política que muito me interessa. Além desses artistas específicos que citei no repente pesquiso também instrumentos não ocidentais e vejo uma grande riqueza principalmente nos instrumentos desenvolvidos nos "terceiros mundos" e que fogem da luteria tradicional por motivos econômicos e socioculturais, e se desenvolvem com a idéia de "faça você mesmo". Mas, de maneira geral, todas as pessoas com que toco ou converso sobre música, artes em geral e técnicas - que acabo usando para meu trabalho - considero como influências até maiores do que os nomes que citei acima. Claro que isso gera um número infinito de nomes, impossível de listar aqui, mas o artista que não posso 
esquecer é o Elto, vulgo Chocolate com quem eu comecei a grafitar "Cores" no inicio dos anos 90. Que outras pessoas você conhece que desenvolvem algo semelhante?

Permita a escapada, mas levarei minha resposta por outro caminho, não acredito que o que faço seja de grande originalidade e não acho que isso defina as qualidades de um trabalho, mas pesquisando artistas para um evento que organizo chamado "Panorama da Luteria Experimental em SP" busquei tanto em São Paulo, como nos outros estados brasileiros e no mundo e acredito que a pesquisa, curiosidade e experimentação me aproxima de quem faz luteria experimental de maneira geral, mas ao mesmo tempo a experimentação por si gera muitas particularidades para o trabalho de cada indivíduo tornando difícil a comparação e delicadas as aproximações.

\section{B.1.6 Eloi Silvestre - Entrevista}

Eloi Silvestre é programador, músico e tarólogo, e constrói instrumentos a partir do reaproveitamento de objetos e circuitos eletrônicos. Entrevista por Facebook Messenger dia 06 de março de 2018.

Como você descreveria o seu processo de construção?

O processo de construção dos instrumentos era todo baseado no acaso e no processo de tentativa e erro. De uma forma geral eu ia encontrando as peças e combinando até ter resultado.

\section{Que nome você dá ao isso que você constrói?}

Eu nunca pensei em um nome para o que eu fazia.

O que você ou outras pessoas fazem com estes objetos? Como você classificaria isso?

Eu mesmo usava meus instrumentos no grupo LCD, junto com o Paulo Beto e o Miguel Barella. Era um grupo de música experimental.

Algum destes projetos é mais representativo do seu trabalho?

O LCD é o mais representativo - Eu criava os instrumentos para poder interagir com meus companheiros. Gravamos alguns CDs, tocamos em galerias de arte, nos SESCs, CCSP, em um festival em Barcelona.

\section{B.2 Parceiros e gatorristas}

\section{B.2.1 Eduardo Santos}

Eduardo Santos é produtor, radialista e apresentador de TV, sediado em Porto Alegre. Foi uma figura importante na cena musical alternativa gaúcha dos anos 1980 e 
1990, tendo trabalhado na Rádio Ipanema. Entrevista realizada por telefone em 10 de março de 2018.

Como você conheceu o Tony? Você lembra quando foi? Que recomendações e ajudas você deu ao Tony nesse começo de carreira?

Então, eu conheci o Tony quando ele levou o material pra gente lá na Ipanema, isso faz muito tempo, eu não me lembro a data exata, mas foi um primeiro contato que a gente teve com ele. E aí, a partir dali, daquela primeira ida dele lá na Ipanema, a gente tinha um programa na tv que se chamava College na TV, e aí a gente combinava com ele dele ir pro programa pra fazer algumas apresentações, ele ia sempre que era feriado, era o dia que o Trensurb não tinha muito movimento. Ele ia pro programa sempre em feriados porque o trem não era tão movimentado e pra ele ficava tranquilo levar a gatona, a caixa de som, nos outros dias era complicado dele entrar no trem com todas essas coisas. Então ficou meio combinado que como o programa era ao vivo, sempre em feriados o Tony dava um jeito de aparecer lá, a gente já sabia que ele ia aparecer, ele não tinha telefone celular, não tinha telefone em casa, alguns amigos às vezes ligavam avisando que ele ia e tal, mas era meio esperado, então a gente sempre deixava um espaço na pauta da TV pra ele aparecer, acho que no YouTube deve ter algumas coisas do Tony no College na TV.

\section{O que te chamou a atenção na música dele?}

O que chamou atenção na gente, de maneira geral, era o tom de protesto de um cara que na verdade era um técnico em eletrônica, eletrotécnica enfim, arrumava videocassete, aparelho de som, toca-discos e tal, e que fez um instrumento e que as letras ele tinha uma linguagem muito clara pra protestar de coisas muito pontuais das injustiças da sociedade mesmo, e do sistema político nacional, enfim, de toda essa coisa que até hoje ele mantém. E algumas coisas engraçadas assim, um cara da Paz, né? Chamou atenção a música do "Antônio Daudt amava a paz", o Antonio Daudt era um cara muito conhecido aqui na TV Gaúcha nos anos 70, foi assassinado, então ele misturava Antônio Daudt com a Daniella Perez assim, era uma coisa bem maluca, eram umas coisas disconexas porém conexas, então isso que chamava atenção. E aquela coisa industrial daqueles timbres ruidosos que eu acho também é um pouco dessa estética que acompanhava esse tipo de letra que ele escrevia, tudo fazia parte e deixava aquele conjunto todo meio um soco na cara da sociedade.

Como você vê a relação da música do Tony com a música gaúcha? A relação dele com a música gaúcha, não sei, eu acho que o Tony ele é um ato de protesto, sabe? Não sei se ele chega a ter uma relação com uma música gaúcha mais aprofundada, a galera gosta dele, né, tipo o Fred (CNJ) fez um remix dele, ele transita com a galera, quando tinha os shows coletivos da rádio a gente colocava ele pra tocar, sabe, é um cara muito querido por todo mundo. Mas ele não teve uma relação musical com a cena gaúcha assim, ele é uma coisa à parte, ele é uma instalação, né, ele é um negócio que vai um pouco além das coisas do tal do rock gaúcho. 


\section{Que outras pessoas do meio musical Gaúcho / Portoalegrense você con- sidera importantes na carreira do Tony?}

Eu acho que quem foi importante na carreira dele aqui, acho que o Miranda deu uma força quando o Tony tentou conectar as coisas em São Paulo, o Miranda que já morava aí indicou ele pra algumas pessoas e tal, a galera da CNJ, o Fred e o Chernobyl também fizeram coisas com o Tony assim, o Carlinhos da BouB, a galera citava muito ele e tentava dar espaço pra ele, enfim, de maneira geral acho que é um cara muito querido por todo mundo aqui.

\section{Como tem sido a tua relação com o Tony ao longo dos anos?}

A relação com o Tony meio que continua, cara, ele de vez em quando aparece na produtora. Quando o meu filho nasceu eu encomendei uma gatorra pro Tony pra dar pra ele de Natal, e aí foi quando eu comprei a primeira gatorra, depois eu comprei uma minigatorra. De vez em quando ele aparece lá na produtora com umas invenções, esses tempos ele foi lá com um batucador, aí depois ele foi com um batucador que sequencia também, a gente pegou também, de vez em quando ele aparece pra bater um papo, almoçar com a gente, levar essas invenções dele. Esses tempos ele levou alguma coisa que era pra, eu não me lembro exatamente pra quê que era, eu sei que o Anderson do nosso administrativo lá que pegou, é uma coisa que tu põe no carro pra, sei lá, desligar o carro pra quando sei lá o que, enfim, umas traquitanas, ele é um inventor, né?

\section{B.2.2 Carlos Eduardo Miranda}

Carlos Eduardo Miranda foi um dos produtores responsáveis pela divulgação e consolidação da cena musical alternativa no Brasil, nos anos 1990. Também produziu diversos discos de artistas brasileiros, e trabalhou como jurado em programas de TV. Entrevista realizada por telefone em 7 de março de 2018.

Como você conheceu o Tony? Você lembra quando foi? Que recomendações e ajudas você deu ao Tony nesse começo de carreira?

Os meus amigos lá de Porto Alegre começaram a descobrir o Tony lá, aí um deles era da rádio, que é o Edu Santos, era da Ipanema, e tinha uma produtora, hoje ele tem um selo, tem um monte de coisa lá. E o Tony já tava virando um mito lá no Sul. Um dia ele veio pra São Paulo pra gravar alguma coisa no Raul Gil, eu acho, ou na Globo, aí esses meus amigos de lá já tinham falado muito de mim pra ele, dele pra mim, a gente se conhecia sem se conhecer, e deram pra ele o meu telefone de São Paulo [...] pra ele chegando em São Paulo qualquer coisa ele me ligasse, né? Aí tou eu na Trama, toca o telefone: "Ô Miranda, aqui é Tony da Gatorra", aí eu "Opa, Tony, beleza?" e tal, ele: "Bah, tou apavorado aqui, tou sem dinheiro tou num hotel aqui em frente à rodoviária, parece uma casa fantasma, só tem uns marginais aqui, não sei o que fazer". Era um hotel de 
craqueiro, sabe, era um lugar bizarro assim, ele tava desesperado: "Preciso de uma ajuda aqui, cara, alguém tem que vir aqui me fazer alguma coisa pra me tirar daqui, que eu não sei nem como sair daqui". Aí eu falei "Dá uns minutos aí que eu vou dar uma pensada, vou resolver teu problema".

Daí eu não podia sair da Trama aquela hora porque eu tava no meio do trampo, né? Aí eu falei com o Dago, e eles tinham aquele selo que era junto com o Du Ramos, e com o Gui, tinha a festa lá no Milo, isso no começo dos 2000. Deve ser por aí, 2002, 2003 então, que o Dago antes trabalhava na assessoria de imprensa da Trama, mas aí ele tinha a festa lá no Milo com o Gui, o Gui vendia disco por telefone, tele entrega, a Peligro, aí eu falei: "Tony, tu tem uns discos aí contigo?" "Eu tenho uns 10 discos aqui, cara, te dou eles de presente, mas me salva daqui", eu falei "Não, não me dá de presente, peraí que eu vou agitar um negócio". Aí eu falei [com o] Dago, "que tu acha de ligar pro Gui, fazer um rolo, apresentar o Tony da Gatorra pra ele, ele tá com uns discos aí a gente dá um jeito de vender e dá uma ajuda pro Tony, e vamos botar ele no circuito". Aí o que que eu fiz, eu liguei pro Gui e falei "Gui, o que que tu tá fazendo, velho?". Que o Gui morava na Apinajés, era mais perto pra ir até a rodoviária, "Tu tá livre?" "Tô, tô de boa", eu falei "Então é o seguinte, tem um cara aí, mano, que é o Tony da Gatorra" expliquei pra ele "o cara inventou um negócio assim assado, ele veio pra gravar um programa do Raul Gil, ele tá lá no hotel, pelo jeito é um lugar de crackeiro, ele tá apavorado, tu não tá afim de ir lá, salvar ele de lá, ajudar ele a ir embora, dar uma guarida pra ele, aí ele te dá os discos a gente vende os discos pelo site, que é um negócio muito doido o que ele faz, é legal pra caramba". Aí ele topou, aí eu liguei pro Tony e falei "Olha, Tony, vai chegar aí o Guilherme, vai te procurar, ele vai resolver teu lance, tu passa os discos pra ele, que ele vai agitar tudo o que precisa".

Aí o Gui foi, conheceu ele, tirou ele de lá, aí ele entrou pra turma, a galera começou a ajudar ele, aí lançou o disco dele, fez o disco pela Peligro, daí começou a botar ele pra tocar nos negócios do Milo, aí no fim das contas a coisa foi crescendo, aí o Du Ramos, que era um cara sempre articulado pra caramba botou ele num esquema com a Brahma que tinha pra ir pra Europa, com a Trama, ele foi tocar, apresentou ele pro Gruff Rhys, o cara do Franz Ferdinand comprou gatorra, a Lovefoxxx comprou gatorra, aí ele virou um ícone.

$\mathrm{Eu}$, a primeira vez que eu encontrei com ele pessoalmente, foi num show no Milo, a gente tirou até uma foto junto. Ele ficou muito emocionado, "Pô, Miranda, finalmente a gente se encontra", porque a gente acabava resolvendo as coisas pelo telefone, ajudava ele, mas deu muito certo.

Eu peguei a Trama Virtual e fui testando ela em segredo durante mais de um ano, eu acho, até encher de música, até limpar o que não funcionava, até eu ver que tava no ponto, depois que a gente foi lançar. O Tony já entrou nessa época. A Trama Virtual foi doido porque dali saiu uma geração muito grande e a gente às vezes não para pra se 
ligar, se for ver o NXZero, Fresno, Cansei de Ser Sexy, Apanhador Só, Tony da Gatorra, tudo vem dali, é um movimento que parece que não tem um eixo, mas tem na Trama Virtual. O que era legal no Trama Virtual é que era uma coisa feita que era viva, não era uma plataforma morta, porque eu via vários sites que testavam isso, e todos erravam, porque todos eram uma plataforma que não se relacionava com o mundo real, era muito duro o negócio. E uma coisa que eu entendi sempre é que internet não é um lugar pra plataforma, é um lugar pra humano, relação, e a Trama Virtual eu já fiz pensando isso. E a simplicidade também, porque a gente vinha de uma internet toda lúdica, a própria Trama era toda cheia dos nheco-nhé, eu era muito contra isso. Eu queria um negócio que a pessoa entrava, prático. Pra que que tu vai ficar sentado na frente do computador apertando, clicando nuns lugar que tu não sabe pra que que serve? Tudo na internet era meio isso.

Aí eu falei, não, meu negócio aqui é Amazon, é praticidade, tem que entrar e funcionar, véi. Tem que chegar onde quer, ser sugerido aonde ir, ser bem recebido. É que nem tu ir numa loja e as pessoas da loja estarem limpas, bem-vestidas, sorridentes, entendendo do assunto, era meio isso, e a nossa equipe todo mundo tava na rua o tempo todo, todo mundo ouvia tudo o que chegava, tu podia postar o que tu quisesse, mas tu só ia pro ar se a gente aprovasse. E ainda tinha o joinha, né?

Era uma galera totalmente ativa, Dago, Fernanda, o Six, o Leandro, era uma galera legal. E todo mundo acabou indo longe no caminho, né? Foi legal pra caramba. Pena que eu saí da Trama antes de terminar o projeto, eu ia adaptar ele muito, eu já tinha tudo planejado, ia virar tipo um Facebook, só que só de música, pras pessoas se relacionarem. Ia ser muito mais legal, ia ter coisa ao vivo, estúdio, só que aí abortaram a missão, é a vida, né?

Essa coisa dele virar um cara meio mitológico, fazer um disco com o Gruff Rhys, tu entra numa Apple Music, Spotify, tá lá o cara, véi. Ele ficou na história da música, daqui a alguns anos vão ficar descobrindo ele, os caras que procuram música estranha, coisa no mundo. Ele tá com o nome dele na história, que ele nunca sonhou que ele seria capaz, pra um cara de Esteio que tocava na praça, mano, isso aí foi tipo um milagre, dá pra fazer um filme.

\section{Como você vê a relação da música do Tony com a música gaúcha?}

Completamente, né, velho, porque gauchismo é um negócio tão forte, tão lascado. O cara ser gaúcho é tipo ser gaulês, tu vive numa aldeia isolada do mundo, perto do gaúcho aqui no Brasil só o pernambucano e o paraense, com a diferença que o pernambucano e o paraense tem uma riqueza cultural enorme, e o Rio Grande do Sul é uma falcatrua cultural, a cultura gaúcha foi inventada pelo Barbosa Lessa e pelo Paixão Cortes, eles criaram tudo, quando eles viram a Bossa Nova eles falaram "O quê? Mas nos temos que fazer algo assim pra nossa terra". Aí eles juntaram tudo que tinha pelo estado inteiro e criaram a figura de um gaúcho que não existia, criaram uma tradição gaúcha que não 
existia, aquilo ali é tudo inventado. No Rio Grande do Sul foi uma coisa que era criada por dois intelectuais, que formataram tudo.

Total, é um cara que tem uma visão do $c^{*}$ do mundo, é o cara que tá assim num lugar que é o fim do mundo, e a opinião dele é da visão que ele tem de lá, uma coisa muito provinciana, e ao mesmo tempo consegue ser internacional de tão louco que é. Que isso é o Rio Grande do Sul, né? Mais ou menos essa coisa esquizofrênica, de ser um lugar muito provinciano, muito retrógrado, conservador, e ao mesmo tempo desatinado de louco né, véi? Que daí comunica com o planeta.

Eu acho que é uma coisa do pôr-do-sol que os caras acham o mais bonito do mundo, faz comer x-coração, pizza de estrogonofe.

\section{B.2.3 Dago Donato}

Dago Donato é jornalista e produtor cultural, em atividade em São Paulo desde os anos 2000. Foi um dos responsáveis pela divulgação do trabalho de Tony da Gatorra na mídia a partir de 2004. Entrevista realizada por e-mail em 9 de março de 2018.

\section{Como foi o seu primeiro contato com o Tony da Gatorra? Vc lembra quando foi?}

Foi na Trama. Acho que o Miranda mostrou pro pessoal da TramaVirtual. Ficamos fãs. Na época, eu tinha uma loja na Vila Madalena em que rolavam festas com shows. Um dia o Miranda me fala: o Tony vai te ligar. Ele me ligou. Estava em SP e queria marcar um show. Só que ele não parou de me ligar. Fez várias ligações no mesmo dia e senti que ele tava tenso. Botei um pressão e ele falou o que tava rolando. Ele não tinha grana pra ficar até o dia do show e nem pra voltar pra Esteio. Senti que a situação era meio séria, mas eu tava no trabalho e não conseguia sair pra ajudar. Liguei pro Gui, que tinha a Peligro na época e marcava os shows na minha loja, contando e ele falou que ia dava um jeito. Colou no hotel que em o Tony tava hospedado, comprou todos os discos que ele tinha trazido e botou ele no ônibus de volta pra Esteio e prometeu trazê-lo de volta pra uma série de shows. Foi o que rolou no ano seguinte.

\section{O que te chamou a atenção na música do Tony?}

Ele era um brasileiro fazendo outsider music, aquela música fora dos padrões convencionais que é ingênua, intuitiva e - mesmo sem querer - vanguardista. Pra quem gostava de Shaggs, Wesley Willis e Daniel Johnston, ele era a personificação do músico outsider brasileiro. E mais, ele tinha o pacote completo: visual fora de época, letras com mensagens políticas, inventou um instrumento retrô-futurista. Depois de conhecê-lo, ainda passei a admira-lo como pessoa. Tony é um guerreiro por sua família, sua arte e seu país. 


\section{Você já trabalhava na Trama nessa época, né?}

Cara, acho que fizemos para ele. Mas não lembro bem como foi. Era parte do pacote de apresentar o Tony pra cena.

Eu queria saber um pouco mais sobre esse começo do Tony em SP, junto com aquela cena que tava rolando na época e que movimentou bastante a cidade.

No fim de 2004 fechei a loja e no começo de 2005 começamos a fazer a festa da Peligro no Milo. Rapidamente a festa virou um ponto importante da música da cidade. Fazíamos shows bem variados (uma semana podia ser a Deize Tigrona e na outra o Elma, na outra uma banda de free jazz e na outra um grupo de rap) e criamos um público interessado nessa diversidade. Colocamos o Tony pela primeira vez em maio de 2005 e foi estouro. Se não me engano nessa mesma vinda ele tocou na Funhouse também. Passamos a trazê-lo regularmente para fazer shows na Peligro e em outros lugares de SP.

Fale um pouco sobre como a tua relação com o Tony se desenvolveu ao longo dos anos.

Foi mais intensa nesa época da Peligro no Milo. Fizemos muitos shows dele em SP, fizemos um em Curitiba, dava uma força pra ele na TramaVirtual, apresentamos ele pra muita gente. Pessoal começou a comprar gatorra... Quando abrimos o Neu, tiramos o foco dos shows. Tínhamos uma casa noturna pra cuidar e achávamos que ele já estava bem encaminhado também, fazendo parceria com o Gruff Rhys, gatorras vendidas pra celebridades, shows em alguns festivais. Dei minha missão como cumprida.

\section{B.2.4 Binho Miranda}

24 de maio de 2018

Eu queria saber como foi o teu encontro com o Tony, e como foi essa história de você comprar a gatorra $\mathrm{n}^{\mathrm{0}} 2$

Eu fui num show na antiga Milo Garage, tava lá a barraquinha de discos do Gui [Barrella], da Peligro, comprei vários discos, um deles foi o do Tony. Mas, sinceramente, eu não lembro direito. Posso ter conhecido o trabalho dele antes, mas sei que o Gui foi o grande responsável em me apresentar o Tony. Eu fiquei muito empolgado com a figura dele. Dai o Gui me deu cartas que o Tony mandava pra ele e também comecei o processo de gravar um documentário, que até hoje não terminei.

Neste processo de gravar o documentário, eu fui pra Esteio, minha ex-namorada morava em Porto Alegre, dai foi fácil chegar. Antes de ir já tinha me oferecido pra comprar a Gatorra $\mathrm{n}^{\circ} 2$, o instrumento que a gente chama de Gatorra Baixo. Cada gatorra tem um timbre diferente dado os componentes eletrônicos diversos que o Tony usa, fora a 
montagem manual. Sei que comprei a Gatorra pagando em várias parcelas, mandando dinheiro escondido por envelope, por banco postal, depositando na conta de amigos do Tony. Uma doideira.

No Aeroporto, voltando pra SP, logo depois do raio-x um segurança me barra. Eu estava atrasado e ele me mandou abrir o case da gatorra, eu pensei, "Ferrou, não vão deixar subir com este trambolho". O cara abriu o case e o olho dele arregalou:

- Isso é uma...Gatorra!?

- Sim senhor.

- Não acredito! Sou fão do Tony da Gatorra! Manda meu abraço pra ele!

E como foi esse processo de você passar um tempo cuidando das coisas do Tony, marcando show em São Paulo, etc..?

Nunca tinha feito isso. Apesar de ser amigo de muitos músicos, o trampo de produção era bizarro pra mim, mas o Tony precisava de ajuda. Ele chegou em SP totalmente zerado de grana. Ficou num hotel perto da Rodoviária do Tietê. Ligou pro Miranda pedindo ajuda. Dai o Miranda ligou pro Gui e a história seguiu. Depois de um tempo eu comecei a ficar chateado, porque ninguém queria levar o Tony a sério. Nos shows eram muitas chacotas, piadas de mal gosto, agressões verbais. O Tony não merece isso.

Isso ainda na fase com a galera da Peligro e os irmãos Ramos?

Logo depois. O Gui já não tava mais com tempo de cuidar dos rolês do Tony. O Bruno Ramos ainda ajudou bastante depois. Inclusive conseguindo a liberação da necessidade da OAB pro Tony. Eu e o Bruno, a gente se falava pouco mas sabiamos que ambos estavam ajudando o Tony. A amizade veio depois.

\section{E como veio a ideia de fazer um documentário?}

$\mathrm{Na}$ época eu trabalhava numa produtora de cinema. Minha vontade era dirigir algo. Juntei toda a vontade e fui tentar fazer algo com o Tony, mas eu era bem novo, tinha outra cabeça. Hoje teria feito tudo diferente, e certamente terminado o documentário.

E como foi essa tentativa de aproximar o Tony e o pessoal do Garoa Hacker Clube pra uma parceria, foi você que pensou nisso?

Isso ai foi ideia do Tony de Marco, ele participa do Garoa faz tempo, fez a marca dos caras e tal. Mas este tipo de atividade causa um certo receio do Tony. Ele tem muito medo de que alguém roube a ideia dele, os esquemas eletrônicos da Gatorra e tal. Uma das coisas que nunca conseguimos, foi desenhar a placa de circuito de forma profissional e que o Tony pudesse usar para acelerar o processo de confecção. Isso tudo bate neste receio do Tony de entregar os esquemas pra alguém.

Mas tu chegou a participar desse encontro com o Garoa ou foi só uma 
coisa de apresentar uma pessoa a outra? Foi nessa época que rolaram as fotos da gatorra aberta?

Sim, eu fui junto! O Tony não quis que abrissem a Gatorra I, dai lá vai a minha pra sala de operações. Abriram, viram, mexeram. Foi bem legal. Na verdade, foto de Gatorra aberta dava pra fazer aos montes, a minha e a dele viviam em manutenção. Isso é outra coisa, deu pau na Gatorra, só o Tony sabe mexer.

\section{Você sabe se existe registro daquela ida do Tony no Raul Gil?}

Eu tenho a ida do Tony no Raul em VHS, eu acho. Entrou um trecho no documentário. Este foi um clipe que fiz pro tony: <https://vimeo.com/13232951>, os defeitos de VHS saíram desta fita do Raul Gil.

\section{E em que andamento está o documentário?}

Nunca mais mexi. Tem um corte de uns 20 minutos, eu acho. As fitas e decupagem estão todas espalhadas por vários lugares. Desde que parei de gravar o Tony, me mudei de casa várias vezes.

\section{B.2.5 Graeme Ronald}

Graeme Ronald é percussionista e membro da banda escocesa Remember Remember. É o atual proprietário da gatorra número 7, construída originalmente para Nick McCarthy, da banda Franz Ferdinand. 14 de novembro de 2017

\section{Como você ficou sabendo da gatorra? Como ela chegou até você?}

Eu ganhei a gatorra em 2007 de um amigo músico, Nick McCarthy da banda Franz Ferdinand, que ganhou o instrumento de presente de seu inventor, o Tony da Gatorra, com quem o Nick colaborou. Nick conhecia a minha música e meus interesses musicais - instrumentos estranhos, brinquedos, instrumentação não-convencional - e achou que eu poderia usar a gatorra mais do que ele, então ele me deu de presente. Eu não lembro exatamente do número, mas acredito que o Tony tenha feito por volta de uns 12 instrumentos.

\section{Como você usa a gatorra?}

A gatorra é empunhada como uma guitarra, e em alguns aspectos lembra uma $k e y t a r^{2}$. No entanto, a gatorra é uma bateria eletrônica, não um sintetizador. Ela possui botões no braço e no corpo que acionam sons percussivos que podem ser filtrados e ligeiramente alterados. Há também alguns osciladores simples que podem ser manipulados com um controle de frequência, e também um pedal para acionar o som do bumbo.

Quais os pontos preferidos e quais os problemas que você encontrou no

\footnotetext{
$\overline{2}$ Interface de controle para tecladistas que emula a empunhadura de uma guitarra elétrica
} 


\section{uso da gatorra?}

O que eu mais gosto na gatorra é o seu jeito estranho e incomum, no som e na aparência. Eu gosto do fato dela ser uma bateria eletrônica vestível, e que se pode tocar como uma guitarra em vez do formato tradicional de caixa, comum às baterias eletrônicas operadas com pads. As principais limitações são ela ser muito ruidosa e difícil de controlar, e alguns dos sons, especialmente os sons contínuos, são um pouco desagradáveis. O instrumento se adequa bem à música experimental, noise, mas eu sinto que há lacunas que impedem que seja usado em estilos musicais mais convencionais.

\section{Como você toca a gatorra? Você já gravou com ela? Poderia mostrar alguns exemplos?}

Eu não uso a gatorra hoje em dia tanto quanto já usei, mas quando eu me apresentava como um artista solo, usando um pedal de loops, eu usava a gatorra como minha bateria eletrônica. Eu também processava o sinal dela por vários delays e efeitos para criar sons estranhos, barulhentos e experimentais com os quais eu normalmente encerrava minhas apresentações. Não há registros em vídeo dessa fase disponíveis, mas no primeiro disco que eu lancei como Remember Remember eu toquei a gatorra pra criar a batida de uma parte da canção "Mountain". Dá pra escutá-la nesse link: < https://www.youtube.com/watch? $\mathrm{v}=$ DTdAFR9VMSU\&index=5\&list=PLYE-r8eJxWcvQLAVMqsfFKZbB5CP3ji-M >

\section{B.2.6 Marcelo Conter}

Como você ficou sabendo da existência da gatorra e do Tony? Como você entrou em contato com a gatorra?

Não lembro mais como cheguei no Tony, fazem muitos anos, se não me engano foi durante o período em que ele fez gatorras para a Lovefoxxx e o Nick McCarty. Me relacionei mais com o Tony durante 2009, quando participei do Coletivo Concerto Grosso, capitaneado por Marcelo Birck, do qual fazia parte vários artistas, dentre eles Tony e minha banda na época, a Musical Amizade.

\section{O que motivou o seu interesse por encomendar uma gatorra?}

Encomendei porque me parece um instrumento que entrou para a história da música brasileira, ainda que fazendo parte das "notas de rodapé", mas que diz muito sobre resistência ao status quo e ao capitalismo financeiro. O fato de ser feito à mão e não ser um projeto de série também me motivou.

\section{Como você usa o instrumento?}

Eu vejo ela como um sintetizador, só que ao invés de teclado ela tem outra configuração. Dá pra fazer sons percussivos, drones, até melodias se você tiver paciência para testar. Ela não deixa de ser uma silhueta de guitarra / baixo, por causa de seu 
desenho, forma de ser empunhada e o tipo de cabo utilizado, que permite conectá-la a pedias de efeito e multiplicar suas possibilidades.

Quais os pontos preferidos e quais os problemas que você encontrou no uso da gatorra?

Adoro os drones que podem ser feitos com os potenciômetros, ainda mais cruzá-los para gerar ruídos ultra graves. Por outro lado, os botões que tony fez para a mão direita são um pouco frágeis. um deles quebrou, vou levá-la para ele arrumar.

\section{Como você toca a gatorra?}

Através de uma pedaleira de efeitos e amplificador de guitarra, ou através de um amp de baixo.

\section{Você já usou a gatorra em alguma gravação?}

Ainda não, mas estou compondo coisas para 2017.

\section{Você poderia mostrar exemplos do uso da gatorra?}

De tudo o que eu vi sendo feito com gatorras, nada supera a sensibilidade do Gruff Rhys, que conseguiu harmonizar o seu violão distorcido com a performance do Tony. Acho que ali rolou uma dupla fantástica.

Entrevista realizada por e-mail em 8 de dezembro de 2016.

\section{B.2.7 Sérgio Pinto}

15 de março de 2017

Como você ficou sabendo da existência da gatorra e do Tony? Como você entrou em contato com a gatorra?

Por volta de 2003, 2004, eu fazia parte do núcleo de música e artes cênicas do Sesc Pompeia, responsável pela programação dessas linguagens. Neste período, além do contato direto com artistas e produtores, eu acompanhava a programação musical da cidade e seguia algumas listas e boletins. Um desses boletins era da Peligro Discos, do Guilherme Barrella. Foi em um desses boletins da Peligro que eu fiquei sabendo sobre o trabalho do Tony da Gatorra. No final de 2004, quando estávamos começando as pesquisas para a curadoria do 4Hype - quarta edição do festival de música eletrônica que fazíamos à época pensamos em dedicar uma noite para usos expandidos da guitarra. O modelo que tínhamos em mente eram trabalhos do português Rafael Toral ou do austríaco Fennez. Pelos textos do boletim da Peligro, e sem ter ouvido ainda algo do Tony, eu imaginei inicialmente que o instrumento tivesse alguma relação com guitarra. Foi daí que fui atrás de gravações do Tony e que acabei estabelecendo contatos com ele. Eu acabei fechando a programação do festival e, nessa noite, colocamos Akira S, Wolf Eyes, Fennez e o Tony na abertura. 
Esse festival aconteceu em maio de 2005, se não me engano, mas eu já não estava mais no Pompeia, havia sido transferido para a unidade de Santo André. A participação do Tony acabou sendo cancelada, por falta de documentação da OMB - esse foi o show para o qual ele foi convidado, como diz em Meu Nome é Tony -, muito mais por falta de habilidade da produção, que não soube negociar com a OMB.

\section{O que motivou o seu interesse por encomendar uma gatorra?}

O Tony acabou voltando ao Sesc Pompeia, para se apresentar no 5Hype, em 2006. Foi nessa noite que o conheci pessoalmente e encomendei um instrumento. Sempre tive muito interesse em instrumentos incomuns - Luigi Russolo, Walter Smetak, etc. Uma das matérias mais interessantes e das que mais gostei de ter feito na universidade - estudei composição e regência na Unesp - era justamente Organologia, área da música que estuda os instrumentos. Nesse período em que conheci o trabalho do Tony, muito se falava no "efeito colateral do sistema" que representava o uso imprevisto da tecnologia digital por parte de comunidades marginalizadas - funk carioca, tecno-brega paraense, reagaeton latino, etc. Para mim, a gatorra fazia parte um pouco desse universo, embora Tony não trabalhasse dentro desses cânones. Mas o fato do instrumento ser, ao mesmo tempo, de baixa tecnologia e conter conceitos das vanguardas do princípio do século XX - como as máquinas de fazer ruídos de Russolo ou dos futuristas russos - é o que mais me fascina.

\section{Como você usa o instrumento?}

Eu pouco utilizo o instrumento, até porque não tenho feito nenhum trabalho artístico mais constante. Eu o utilizei em umas 3 oportunidades apenas: em uma festa de amigos; em uma apresentação do Tony no Milo Garage; e uma apresentação dele na Sensorial Discos, onde acabei dando uma canja nesses dois shows.

Quais os pontos preferidos e quais os problemas que você enfrentou no uso da gatorra?

Os pontos preferidos são a facilidade de execução do instrumento e o seu conceito mesmo que não declarado pelo Tony - de uma bricolagem tecnológica de componentes e sucatas industriais. Os problemas estão no projeto de seu circuito eletrônico - não tenho conhecimentos técnicos profundos de eletrônica, me interessa mais a estética da linguagem, e posso estar errado nessa minha avaliação - o que torna o instrumento extremamente ruidoso. A sua fonte de alimentação é muito baixa e a impedância impede de você conectálo a um DI balanceado, por exemplo. A minha gatorra é a de número 6, bem antiga, e segundo o Tony, ele vem aperfeiçoando o instrumento; talvez por isso a minha tenha tantos problemas nesse sentido. Ele já a levou para consertar umas 3 vezes, já trocou fonte, cabos, mas o problema persiste.

Como você toca a gatorra? Você já usou a gatorra em uma gravação? Você poderia mostra exemplos do uso da gatorra? 
Quando eu toquei junto com ele, no Milo Garage, foi com um outra gatorra, não com a minha. Na Sensorial Discos, em 2014, havia uma produção mais cuidada, sob a responsabilidade do Paulo Beto e do Arthur Joly. Todos estavam usando instrumentos mais novos que o meu e bem equalizados o sistema de som que estavam usando. Ao final, me chamaram para uma canja, eu usei a gatorra do PB, que estava com um som mais redondo, pude fazer uns ostinatos com tons mais graves, que ficaram bem interessantes. Eu não tenho nenhuma gravação de algo que tenha feito com ela, mas ainda tenha planos de utilizá-la montando um pequeno set com instrumentos peculiares que venho adquirindo, como Cracklebox, Nanoloop, etc. E esperanças de que o Tony ainda consiga dar um jeito e tirar um pouco do ruído.

\section{B.3 Entrevistas com Tony da Gatorra}

\section{B.3.1 21 de março de 2015 - Casa do Mancha}

Entrevista feita por Leonel Mancha, Kátia e José Guilherme Lima

Então vamos falar um pouquinho do seu trabalho, como é que tá o trabalho lá? Você tá morando em Esteio ainda?

Sim, eu moro em Esteio. Eu continuo, eu tenho oficina, sabe? Eu faço manutenção em aparelhos eletrônicos ainda, e quando surge surgem shows, alguma coisa, eu tou sempre presente. Eu também construo a gatorra, entende, que é meu ganha-pão.

\section{Quantas gatorras você já vendeu até hoje?}

Até hoje foram 18 gatorras, grandes, e 7 minigatorras, pequenas, né? E também trabalho muito, vendo muito CD também, então meu trabalho é esse.

\section{E o batucador, fala um pouquinho do batucador}

Esse circuito aí que é uma bateria eletrônica, eu chamo de batucador, é o novo projeto, que eu tou construindo agora, sabe? E também juntamente com um novo projeto que eu tou agora com a ideia, e na próxima gatorra que eu fizer, que é uma de número 20, que eu já tenho o projeto pronto pra montagem que vai ser a gatorra sem fio, com transmissor, né?

\section{Uma gatorra wireless}

É, vai ser sem fio, com transmissor,

\section{E você tá compondo músicas novas, inspirado no momento do país}

Sim, as próximas músicas agora na verdade, vai ser um protesto ecológico, por causa da situação, justamente por causa dos descaso desses governantes, que dizem governar, a situação que está aí é justamente por causa de que eles não produzem, não fazem nada, é 
o que tá acontecendo aqui no Brasil, entende? Principalmente muito desmatamento na Amazônia, que tem muito a ver com esse problema do clima que tá acontecendo aqui, né, o grande desmatamento influencia bastante, entende?

As músicas do seu primeiro cd, Só protesto, quando que você compôs essas canções? Faz tempo? Porque elas são bem atuais, na verdade

Sim, dos protestos políticos, né? Sim, o meu trabalho todo é voltado em cima dessa situação entende? Eu já me criei já vendo a calamidade, eu sei quem é o responsável por isso, e hoje que tá ocorrendo a mesma coisa que ocorreu comigo quando eu era criança, e continua essa situação, entende? E eu procuro fazer à minha moda, fazer minha parte, simplesmente protestando e tentando comunicar, pra esclarecer as pessoas, conscientizar, dizer aquilo que é necessário no Brasil. Que não pode aceitar essa situação que eles impõe, os governantes, que se dizem governantes, o Brasil não tem governo, entende, é um pais sem lei. Imagina um país que as pessoas não tem liberdade de ir a parte alguma, que tá com um revólver na cabeça, cheio de ladrões na rua, isso é uma calamidade, né?

E Tony, o que que você tá escutando agora? Qual o seu disco favorito?

Eu sempre escutei rock mesmo, que eu gosto, né? Eu escuto todo tipo de música, eu gosto das músicas tanto das bandas brasileiras, quanto das bandas estrangeiras, e é isso aí, a gente vai curtindo som, né? Eu gosto muito do Rolling Stones, Creedence Clearwater Revival, Pink Floyd, também Legião Urbana que nós temos aqui de São Paulo, as bandas boas, né? Então eu curto todo tipo de música.

O que que você achou ontem e hoje dos shows, das coisas que você ouviu, do jeito que o pessoal tocou a gatorra?

Pra mim foi muito gratificante. Imagina a gatorra, que foi um trabalho que eu construí, e vendo várias gatorras e as pessoas dizendo que gostaram e tão entusiasmadas, isso é gratificante pra mim, eu fico muito feliz com isso.

E hoje foi a primeira vez que a gente juntou várias gatorras diferentes, de várias épocas, o que você foi mudando ao longo do tempo? Você tava falando da gatorra do Binho, do Bruno, do Gui, que tem tudo sintonizável, da Lovefoxxx

Eu procuro sempre aperfeiçoar a gatorra, entende? Cada gatorra tem algo sempre um pouco diferente, né? Inclusive como eu tava comentando agora, a próxima gatorra que eu vou construir ela vai ser sem fio, isso já é uma inovação, é um aperfeiçoamento. Eu procuro sempre botar algo novo nas gatorras, né? Vamos ver até onde vai, as gatorras, a gatorra sem fio agora vai ser uma novidade, né?

Eu tava olhando que na gatorra do Nick, por exemplo, tem vários controladores 
É, dá pra sintetizar ali, o sintetizador que eu chamo, né? E aquilo ali serve também pra deixar o timbre longo ou curto, né, de cada percussão, no caso bongô, tambor, aquilo ali é legal. As primeiras eu fazia todos os timbres sintonizados, e tem umas que tem duas sintonias, ou quatro, eu procuro sempre botar alguma coisa diferente, é que eu achei mais componente pra botar sintonia, no momento tá ficando mais difícil, então é por isso que agora eu tou botando dois ou três.

Aquela sintonia você achava mais fácil fazer com aquele componente da televisão?

É, aquilo ali é de TV antiga, não tem mais, é um circuito analógico, e tá difícil de encontrar na praça aquele sistema ali, de sintonia.

A do nick já não tem mais, aquela verde e amarela

Ela tinha parece que seis, pra sintonizar seis timbres.

A do nick qual que foi, é a seis?

Não, é a número sete. A seis é do Sérgio Pinto, a cinco é da Lovefoxxx, a oito é lá do Rio Grande do Sul, é do Diogo, um amigo lá, da cidade de Montenegro.

Ela ainda tem esse timbre sintonizável?

Tem, essa aí parece que tem 12, tudo pra sintonizar.

A nove de quem que é?

Ih, a nove tá no Rio de Janeiro, eu nem me lembro mais o nome. A dez tá em Porto Alegre, eu não me lembro o nome também.

\section{A do PB qual que é?}

Aquela ali é a quinze, aquela ali eu sei. Eu sei que a catorze tá em Porto Alegre, a treze tá em Porto Alegre também.

\section{Quais são as do Eduardo?}

A treze é do Eduardo Santos, e a mini dele parece que é a número 4.

E a mini 1, de quem que é?

[Longa pausa] A mini 1 é de um amigo meu lá do Rio Grande do Sul, essa da Lulina é número 2, ela não tem nem display...

Ela tem display, só que eu não lembro se é 2 ou é 5 , porque eu sou canhoto e pego ela ao contrário

Então é a dois, eu comecei a por na dois.

Então a 7 é do Paulo, a da Lulina é a $2 \ldots$

A número seis tá no Rio de Janeiro, o cara do Skylab comprou, né? A do Eduardo 
Santos é a quatro... Existem 19 gatorras grandes, e 7 minigatorras, 3 batucadores, o do Binho é o número 1, foi negociado aqui na casa do Mancha o batucador 2 e 3, um tá indo pra Europa, né?

\section{B.3.2 6 de maio de 2016 - Santa Ifigênia}

Transcrição de entrevista e trechos de conversa, com a participação de Arthur Joly. Arthur Joly

por exemplo o capacitor, o capacitor de 2 nano, por exemplo, ele vai dar um agudo, sabe? Vai dar um sininho, né, agora se tu colocar um de 22 nano, já dá um tambor forte, entendeu como é que é?

Arthur Joly - Mas e o ataque pra ele sumir, como é que vc faz pra ele vir e sumir de novo, quando você dá o trigger nele?

Do prato, do bumbo, do tambor?

Arthur Joly - Qualquer coisa, pra disparar o tambor, como é que você faz, você abre e fecha?

Tu quer dizer do pulso? Ah tá, pra provocar o som, ali eu tenho dois sistemas que eu uso, eu uso corrente negativa, por exemplo agora eu tou usando corrente positiva, eu aplico na entrada da base do transistor, o pulso, né? Aí quando tu bota o pulso positivo ali, aí o transistor leva aquele baque, daí ele aciona o sinal na base, aí ele começa a oscilar porque ele recebeu o pulso.

\section{Arthur Joly - Aí o tempo de duração é outro capacitor?}

Não, o tempo de duração aí é o potenciômetro, aquele de 100k, é o resistor, por exemplo se eu deixar fixo ele fica só naquele "tuc, tuc", agora se eu botar o potenciômetro aí se tu aumentar, se eu botar em 60k o valor ele vai ficar "tum", se eu botar em 80 vai ficar "tuuuum", mas se eu botar fixo ele faz "tum", faz o bumbo, "tum tum tum". Então ali naquela parte de baixo eu uso fixo, boto o resistor, né, e naquele pra fazer o sintetizador eu uso o potenciômetro.

\section{Arthur Joly - Você nunca fez um esquemático disso aí?}

Tenho, tenho tudo

Arthur Joly - Mas você achou isso ou você que criou isso aí?

Ah, isso é um pedaço de cada lado, fui emendando, agora o que eu fiz sozinho mesmo foi o pulso, esse não existia, esse eu apanhei.

Arthur Joly - Porque eu também tentei várias vezes fazer bateria eletrônica de síntese assim, e toda vez que eu procurei eram uns esquemas muito grandes... 
E complexo, né? É, e aquela ali é uma ideia muito eficaz. E esse pulso aí, Joly, o primeiro quando eu comecei eu me dei mal, sabe o que acontecia? Eu aplicava o pulso, ele dava o som, mas quando eu soltava a tecla dava de novo, tchê, dava o mesmo, aí eu pensei "E agora?". Aí eu tive que resolver o problema, tu viu só?

Arthur Joly - Com diodo, você fez?

Exatamente, ele entra e pra não dar retorno ele passa por um diodo, aquele de uso geral, 4148, e eu posso por uma resistência, por exemplo, em série com ele pra amortecer, pra não danificar o transistor, né, pra não dar aquele pulso seco. Ou não, também, né? Mas tem o resistor ali dentro, de 10k, e depois o diodo pra não dar retorno.

\section{Arthur Joly - Então é um transistor pra cada timbre?}

Só um só, eu até andei comprando, eu uso aquele de baixo ruído 549, bc, né?

\section{Arthur Joly - E pra fazer o chimbal você faz o ruído como}

Ah, aquele ali é o ruído branco, isso mesmo, o ruido branco aquele sinalzinho ali, ele foi bem nojento pra eu achar ele direitinho.

\section{Arthur Joly - Você ainda conseguiu filtrar ele pra ficar bem agudinho}

É o que dá o agudo ali é uma bonina que eu uso, aquela bobina ali sabe o que que eu fiz pra dar aquele "tch", eu compro um relé de 12, sabe, e tiro a bobina do relé, que não existe pra vender, né? Eu sou obrigado a desmontar um relezinho e pegar a bobininha dele, pra prolongar o som na saída. Aí eu boto um capacitor, eu uso ali parece que é um n2, um n5, em série com essa bobina, aí vai pra saída. Olha eu tinhas bobinas antes, sabe, eu arrumava lá, depois não achei mais, aí eu descobri que dava a mesma ohmagem, que a ohmagem quanto mais alto, mais o sinalzinho do ferrinho dá. Aí então se eu usar um relé por exemplo desses de 12 volts aí ele dá certo, né? Ele dá quase um 1k, mais ou menos, de ohmagem, então ele é bom que ele retarda, daí ajuda no sinal.

\section{Arthur Joly - Mas você usa algum CI, ou é tudo transistor}

Não, é transistor só, CI eu uso mais nessa programação, por exemplo, que eu fiz, eu uso de contador aquele 4017, o 555 eu uso pro disparo, que é "prrr", são aqueles ali, ele é temporizador, né, e o contador eu uso pra programar, porque ele fica contando, eu uso até pra LED, pra ritmo. Ele é um contador, ele conta até 10, então se tu injeta o pulso numa entrada dele, ele fica pulando lá, né, eu uso pra programar os tambores. Aí cada saída sai ali um pulso positivo, se eu aplico na entrada do bumbo ele vai "tuuum"

Arthur Joly - Aí então se você faz assim, se você pega a saída da perninha 1 , a saída da 3 da cinco ele fica "tum tum"

Exatamente, e essa gatorra de dois braços que eu fiz lá que o Alê quer comprar, ele gostou por causa disso aí, que eu coloquei o 555 e o contador, aí eu peguei e liguei, 
cada saidinha eu liguei na entrada do tambor, do bongô e do bumbo, aí com o controle de velocidade, né, que vai no 555. Aí eu botei uma chave, se eu quero só o bongô, aí bota pra ele(faz ritmo com a boca), quer o tambor junto com o bongô (faz ritmo com a boca), aí eu botei nessa gatorra. Eu já fiz umas gatorras antes, eu não me lembro se foi a 8 ou a 10, tem umas gatorras que eu já fiz isso aí, depois eu parei de fazer porque dá muito trabalho pra instalar aqueles CI's todos. Mas essa aí eu fiz agora e o Alê (Fonseca) gostou, parece que ele vai fazer uma proposta pra mim.

\section{Arthur Joly - O 4017 também dá pra você usar um reset se você quiser que fique só em 8 passos...}

Dá, ele pode repetir também a mesma coisa, inclusive tem uma chavezinha que vai do pino 15, parece, que até eu usei também. Aí ele fica parado ali, sabe, aí ele não conta os outros, fica cortando os outros. Ele ignora os outros aí para de contar. Esse 4017, o que tem de esquema dele assim, que dá pra usar, ih, estroboscópica, vu de led...

Arthur Joly - Eu vou fazer pro meu filho um negocinho de piscar luzinha, que ele tá se interessando por eletrônica, então eu ponho o 555 pra mandar o pulso pra ele

É isso, ele vai contar, liga na saída os LEDs coloridos, ele se diverte (faz sons com a boca). Isso os caras usam até pra enfeite de natal, né? E é baratinho aquele 4017, eu acho que é uns dois reais, o 555 também é baratinho, eu pago lá 80 centavos só. É uma utilidade aquilo ali, ele é usado pra temporizador, sabe?

\section{Arthur Joly - Tem muita loja lá, ou não?}

Não, lá não tem nada, Porto Alegre lá pra comprar coisa lá, eu até tava comprando em Porto Alegre mas nem compro mais lá, tem outra cidade que eu descobri, tem uma lojinha que tem o preço quase a metade do valor de Porto Alegre, Novo Hamburgo, que fica duas cidades depois da minha, eu moro em Esteio né, depois tem Sapucaia, São Leopoldo, Novo Hamburgo. Aí o trem vai pra lá.

Arthur Joly - Esteio é grande, ou não?

Não é, é pequena.

\section{Arthur Joly - Mas tem shopping, cinema...}

Não, cinema não tem, tinha. Cinema tu sabe, né, ficaram extintos. Tinha dois, agora não tem nenhum. O centro é bem pequenininho, sabe, a população é maior nas vilas, tem 85 mil habitantes mas o centro é só uma coisinha assim pequena.

\section{Arthur Joly - O que é isso a mais que tem no batucador?}

Isso aí é o controle de velocidade, pra fazer "tu tu tu tu", e aí ele gosta, ele é meio DJ assim, sabe, então às vezes ele faz o som dele lá ele gosta de misturar lá com as pickup 
dele lá. Ele comprou uma gatorra grande de mim e uma minigatorra, aí quando eu fui lá ele comprou esse batucador.

\section{Arthur Joly - A mini ela tem menos coisa ou ela é só menor?}

Não, ela tem menos, o máximo que eu coloquei na mini foi nove timbres só, e depois seis, essa da Lulina parece que só tem 6 timbres.

\section{Arthur Joly - E a minha tem quantos, mesmo?}

Não sei se é nove ou doze, eu não lembro. Acho que é nove, vamos ligar ela pra eu ver, pra eu ter uma ideia ali. Eu queria trocar, eu vou trocar aquela chave pra ti, aquela, essa que eu comprei é boa, é a mesma que tem na gatorra do Missionário e na do Paulo Beto, viu a gatorra do Paulo Beto? Ele fez vários shows com ela, hein, ele nunca disse que deu problema, até hoje eu não vi. Mas se der algum problema pode falar pra mim. E aquela chave ali é muito boa, sabe porque, ela é dupla, aí o que eu faço, ligo em paralelo que daí, vamos supor que dá pane numa, a outra tá funcionando, aí fica uma reserva de qualidade boa, né? Então é difícil falhar, eu uso as duas, viu, ela tem quatro pininhos ali, mas acontece que duas é uma chave e a outra é mais uma, então são duas chaves, que fecham e abrem. Então eu uso as duas em paralelo que fica uma coisa bem reforçada, vai que acontece de dar um pane numa, a outra tá funcionando. A minha também, aquela que eu fiz, essa gatorra de dois braços lá, eu tinha ainda lá e coloquei a chavezinha dupla.

\section{Arthur Joly - A de dois braços, no braço de cima tem o que mesmo?}

É aquela que é digital, que eu coloquei esse 4017 com o 555 pra fazer a programaçãozinha, né? E ficou legal, eu coloquei só três timbres lá, eu coloquei uma plaquinha só com bumbo, bongô e tambor, só. Só que agora os três timbres são controlados por potenciômetro, esses de 100k que eu botei, então tu pode (faz ruído com a boca) deixar eles malucos ali.

Arthur Joly - A caixa você coloca o tambor mais o noise, ou não? Como você faz?

Na caixa, não, é só o ruído branco, é ele tem um pulso ali que entra

\section{Arthur Joly - Então a caixa é o ruído branco, e o pratinho é o ruído} branco com a bobina

Ah tá, o chipô, ali praticamente eu coloco o mesmo circuito, só que só tem uma diferença, é no valor de dois capacitores, pra deixar ele mais sequinho, mais curto. Isso que eu fiz ali, mas é a mesma placa, só que mudam dois capacitores.

Arthur Joly - E você faz as placas na placa furada ou você imprime?

Não, corrói ela no percloreto, tudo desenhado. Eu consegui mandar a mulher fazer a laser, né? Aí eu passo com ferro quente em cima dela, depois eu retoco, às vezes dá umas 
falhas na trilha, né? Aí eu pego a canetinha, até comprei uma caneta pra levar porque a minha tá meio fraca, aí eu retoco ela direitinho e "puc" boto no percloreto. E todas elas, as gatorras, eu que faço a plaquinha. Depois eu saio furando, soldo. A plaquinha do pré, que eu digo, usa dois "transistinho, né, eu coloco dentro da gatorra agora. Eu acho interessante, eu quero ver o ruído, porque eu sempre presto atenção nisso aí, eu ligo ela pra não dar ruído. Eu já eliminei pra diminuir mais por isso, eu tirei a plaquinha dali porque perto do transformador, né?

\section{E como é essa história do capacitor, do cachorro mordendo o rabo?}

Assim o funcionamento, é meio parecido, do sinal que entra na base, e sai no coletor e retorna na base, aquilo ali é o chamado duplo-T, né, é como um cachorro querendo pegar o rabo, fica dando volta ali, assim é o sinal do oscilador, sai e entra de novo, fica retornando na mesma entrada que ele sai

\section{E aí o tamanho do capacitor é que te dá a altura}

O capacitor define o timbre, o timbre do tambor, do bumbo, ou bongô, ou mais agudo ou mais grave, ou o sino, por exemplo, é o capacitor que tem influênca.

E aí o circuito é isso, é o capacitor, você carrega ele, ele descarrega e nesse ciclo

Exatamente, porque a oscilação, por exemplo, você passa por um capacitor que dá mais passagem, como um capacitor mais elevado, mais nano farad, ou menos nano, aquilo ali impede, né? É que nem aquilo que eu tinha comentado do faixa a faixa, tem o capacitor que impede, ou ele facilita ou dificulta pra certas frequencias. A mesma coisa é o oscilador, ou ele facilita a entrada de graves ou impede, os agudos, dependendo do valor dos capacitores, na eletrônica o capacitor é incrível, é fundamental, né? Aliás em tudo, tanto pra receber pulso, pra bloquear, o capacitor tem a capacidade de bloquear o sinal também. E esse sistema aí do oscilador é muito interessante, ele é simples, tu vê só, e é uma coisa que eu acho muito interessante, não é que nem aparelho sofisticado, é uma coisa que funciona bem e é uma coisa simplicada. Vai poucos componentes no oscilador, tanto é que só vai um transistor.

\section{$\mathrm{E}$ isso foi uma coisa que você adaptou.}

Sim, uma parte do projeto fui eu. Outras partes, claro, estudando, né? Tirei uma parte, um pouco daqui, um pouco dali, só o que eu fiz sozinho que eu quebrei a cabeça sozinho, que não me ensinaram no livro é sobre o pulso. Pra enviar esse pulso e fazer o sistema oscilar, o primeiro que eu descobri, quando eu dava o pulso, quando soltava a chave, dava novamente, e aí que eu quebrei a cabeça. Eu me apavorei, né, porque agora eu tou frito, consegui de uma forma que não dava certo, como é que tu vai tocar, não tem como. O preto, o marrom e o amarelo, né? Aí é 100k, eu comprei ali. Não, era 150, era o marrom, verde e o amarelo, 150k. Tu acredita, sabe quanto é que tinha aquele resistor, 
foi a primeira vez que aconteceu, nunca vi isso aí, que eu uso na gatorra, mas eu tenho mania de conferir, não adianta, até transistor eu vou dar uma conferida, no lote eu pego dois três e confiro. Sabe como que funciona um transistor na mão? Então, se tu botar o negativo no coletor e o positivo no emissor, aí se tu botar o dedo na base, tu vai ver ele oscilar no teu dedo. Isso aí eu não aprendi nos livros, eu aprendi com um técnico, fazer oscilar o transistor no dedo, e eu nunca mais eu esqueci. Então eu já peguei transistor, tu testa e aí ele tá bom, mas tu bota ele no circuito não funciona.

\section{B.3.3 18 de novembro de 2016 - Esteio}

Ele me deu, olha só, quase tudo isso aqui, eu comprei pouca coisa. Olha só os componentes aqui, capacitor, tá vendo aí, e mais um estojinho, eu comprei uns potênciometros, isso aqui é da gatorra que eu comprei, mas muita coisa, esses capacitores aqui, isso aqui veio tudo junto. Isso aqui nós compramos lá, te lembra que nós compramos lá na loja?

Sim, sim

Bah, chavezinha boa, né? O Joly me deu um presentaço aqui nem ele sabe o que que ele me deu. Capacitor novinho, soquete, resistor até embalado, né, fora os outros que tem ali na gaveta. É, eu aproveitei, tudo novinho, né, isso aqui foi ele que tinha me dado, os resistores tudo novinho. E tu sabe que cada oscilador daqueles ali, vão seis resistores, e dois são de 100k, bah, de 100k tem um monte, tu vai comprar cada um desse aí, tu vê só né? Eu aproveitei tudo, tudo isso aqui é 100k, esses soltinhos aqui, fora os outros que eu tenho aqui. E LED, também, capacitor também, quase tudo isso aqui veio junto, tinha um regulador também dentro separei aqui, ele me deu um presentão. Ele parou de fazer placa, é?

Foi. Na verdade agora ele até vai voltar a fazer, porque...

Eu pensei que ele mudou o ramo dele, ele agora tá com estúdio, né?

Então, mas ele vai voltar a fazer, ele tá na verdade mandando fazer umas placas, pra fazer uns módulos de sintetizador...

Ah, vai começar de novo, claro, né?

Mas aí ele tá mandando fazer placa em quantidade, assim, de um projeto que ele fez.

Uma coisa que eu tava pensando, né, não sei até de repente se tu tiver tempo pra pesquisar assim, meu computador aí é muito lento, eu uso modem, sabe, então é um problema pra eu ver. Eu tava pensando em mandar fazer, eu não sei se eles fazem em pouca quantidade, das placas, né? Eu queria fazer umas placas de gatorra.

Então, dá pra fazer, eu acho que dá pra falar com o Joly... 
Eu queria umas 50, assim, mas eu não sei se a pouca quantidade sai mais caro, né?

Não sei, são quantas placas que vão numa gatorra?

Daí eu ia montar uma, eu ia fazer a montagem de uma e dizer pro cara "Faz igual a essa aqui". Ou, por exemplo, posso dar o diagrama, né? Que o diagrama que com o computador depois faz as trilhas, também, tem um processo. Então, eu posso botar diagrama, claro, que eu não vou botar o diagrama com os valores, eu boto "R1, R2" assim que o cara bota, "C1, C2, D1, D2", eu não vou dar os valores que daí eu vou dar a gatorra funcionando pra eles, né, não adianta, vou dar de mão beijada o circuito, também não tá com nada. Que nem um cara lá quis fazer isso aí lá no, não sei como é que é o nome que o Binho me arrumou, aí o cara pediu tudo e disse que ia fazer as placas pra mim, sabe?

Foi negócio do Garoa, lá?

É, tu soube daquela história, né?

Você me contou

É mas aquilo ali foi uma coisa estranha. Aí pediu tudo, eu peguei mandei tudo pra eles, sabe, até as medidas e mandei os desenhos pra eles, todo o formato. Nem me respondeu, tchê, faltou até com a educação. Como é que eu vou mandar o diagrama pra eles, eles queriam ver pra montar, de repente, como é que eu vou dar pra eles, assim também não, ninguém me deu nada de graça. Ele queria os diagramas, não dá pra dar, né? Aí eu mandei os desenhos das placas com as medidas, né, aí ele não me respondeu nada...

Eu não sei se essas que o Joly fez, vou até perguntar pra ele aqui

Ele mandou fazer placa, é?

Mas eu não sei se ele fez na China ou aqui no Brasil

Mas ele confeccionou aquelas dele lá?

Então, ele fez um desenho...

Ah, ele mandou fazer, daí...

Ele fez o projeto e aí encomendou as placas, entendeu? Eu não sei onde que ele encomendou, se ele encomendou aqui no Brasil, ou se ele encomendou lá na China, porque tem um pessoal que faz isso

Sim sim, ah, ele mandou fazer na China. Eu já tava pensando, se acontecer isso, de repente eu fabricar em série, eu queria fazer assim umas 50, por exemplo, dá pra fazer, mas o problema meu são essas placas, me dá muita mão-de-obra essas placas, me arrebenta todo, sabe? Eu trabalho muito pra fazer isso aí, é cansativo, pra fazer uma gatorra os caras pensam que é moleza...

$\mathrm{Na}$ real, acho que seria mais fácil e mais prático pra ti se você fizesse 


\section{placa pra fazer um monte}

Sim, pra mim montar não tem problema, montagem eu faço manualmente, né? Agora, fazer as placas, fazer furação, desenhar uma, sabe como é que eu faço, com aquecimento, mas sempre tem que retocar pra ficar bom depois, botar no banho da solução na bandeja, e botar uma só ali.

\section{Você tem o desenho da placa aí?}

Tenho, eu tenho aí os desenhos, eu transfiro [pega uma pasta com diversos esquemas] eu tenho vários aqui, ó. Aí esse Garoa eu montei tudo, montei a do pré, na medida, tchê. Essa aqui é uma delas, essa aqui é de fonte [...] Ó, essa aqui é do prato, acontece que faz uma placa grandinha, inclusive se eu mandar fazer eu vou mandar reduzir, sabe como é que é? Claro, porque é muito grande, essas placas aí, e o cara podia reduzir ela. Porque o japonês consegue reduzir, e eu ia botar os componentes em vez de botar deitado eu boto em pé, sabe? Que daí ganha a medida da placa, reduz. Esse aqui é de amplificador, esse é de amplificadorzinho que eu monto.

\section{E o que você muda é o valor do capacitor?}

É, eu até botei ali, tu viu, o valor ali. Na caixa 2,2, prato 10 micro [...] Tou pensando em fazer essas placas aí, sabe? Tá aqui, esse aqui já é, eu uso três dessa aqui, até quatro, aqui vão três osciladores, aqui ó, um, dois e três, então, são doze. A minha mesmo eu botei nove, eu não sei se a tua tem nove com mais dois de prato chipô, de timbre eu nem sei, são nove com mais duas de prato chipô dá onze, né? Mais os controles, aqueles de ganho todos, misturado, velocidade. Mas a maioria quando eu faço, aí dá doze, aí vão essas quatro placas aqui, 1, 2, 3, 4. Aí vai tudo num quadrinho assim, né?

\section{Aí tu conseguiria condensar isso aqui numa placa só, talvez?}

Sim, sim, botar tudo numa placa só, né? Inclusive reduzir ela um pouquinho, porque daí fica legal.

\section{Você usa isso aqui, aí você imprime na placa e queima no percloreto}

Pois é, isso aqui que eu faço, olha o trabalhão que eu tenho. E aqui eu [faz som com a boca] boto o ferro quente aqui, mas tem que retocar, esse papel não é bom. O melhor papel que tem aí, um cara me mostrou, tem um que ele é brilhoso, e ele é fininho, aí ele solta toda a tinha, e o retoque é mínimo. E esse papel aqui eu não achei, aqui em Esteio, só em Porto Alegre que tem um cara que faz melhorzinho, porque isso aqui é laser, tu sabe, né? É que nem isso aqui, tudo isso aqui é laser, ó, essa aqui é a placa do prato, tu vê só o tamanho da placa do prato. Mas agora eu tenho outro sistema de prato, até coloquei na minha ali, pode ver, o sistema dela aquele ali ficou melhor, bah, eu já aperfeiçoei mais, sabe. Já tou usando outro tipo de prato.

Eu queria te mostrar do préamplificador, isso aqui também é de amplificador, tudo 
isso aqui é o laser, às vezes dá um trabalhão. Então se eu conseguisse fazer, eu queria fazer mesmo, se eu achasse um preço que não fosse muito alto, fazer 100 placas, sabe, nem que eu gaste aí uns 5000 reais, mas aí se tu conseguir te informar disso aí, endereço, tudo lá. Eu tenho todas elas, tá por aí, do preamplificador. Sabe por que, porque o gabinete pra mim é fácil fazer, é rápido, é só dobrar os alumínios ali e fazer a furação dele, então é mais barbada, e o case também, é aquele eucatex, o cara recorta ele, aí compra o carpete, né?

Ah, aqui é diferente, eu ia te mostrar o esquema, isso aqui é um outro sistema, essa aqui que eu coloquei o ruído branco que é o do prato. Mas tem outro sistema com o pulso dele. Aquele meu vão quatro transistores, aqui eu coloquei dois que dão o mesmo efeito, já pensou, isso aqui eu consegui localizar. Mas eu tive que aperfeiçoar o sistema de pulso dele, né? Eles botam só o circuito mas claro que essa explicação aí não colocam, né? Essa aqui é a fonte do pré, a tua é a mesma coisa, essa fonte tem que ser muito especial, ela é de onda completa com regulador, senão dá sempre um zumbido, um ronco, né?.

\section{Essa é a fonte nova que você tá fazendo?}

É, pode ligar, é bem silencioso, as primeiras rocava, sempre dava um ronquinho. Tem que ser regulada, filtrada, isso aqui eu vou te contar, né? Isso aqui (mostra outro circuito) é a mesma fonte, tá aqui regulador de 12, onda completa, e um transistor aqui. Agora eu tou colocando um transistor, pra melhorar mais ainda, essa aqui que eu usei lá ontem eu já mudei, aquela outra não tinha transistor né, eu só ligava aqui, através do capacitor.

\section{E aí o transistor ele te ajuda no que?}

Ele melhora, ele limpa mais, bah, ficou bom, eu resolvi botar o transistor e ficou muito legal mesmo isso aí. Uma proteção contra curto-circuito aqui e um retorno de corrente ali, ele entra duas vezes.

(outro circuito)

Ah, esse aqui é o sistema de misturador do chipô e do prato, viu, do caixa que eu monto. E aqui sai tudo junto pra saída, aliás, entra no controle de agudos e graves, esse aqui é o volume dele.

\section{É isso, dependendo de como você fechar o projeto, dá pra mandar fazer as placas}

Pois é, se eu tivesse placa pronta... Ele dá furadas as placas?

\section{Aí eu não sei, tem que ver, capaz de já vir furada}

É, pro Chinês isso aí é moleza, né? Porque eu andei pesquisando na Internet isso aí, o cara importa a quantidade, dá pronta a placa, sabe? Inclusive até envernizada, né? Já pensou, pra proteção, pra não oxidar, dá envernizada que nem essas placas de (vai buscar) que nem essas aqui, de televisão, tá vendo aí? Tu vê, isso é uma placa de TV, envernizada, 
não oxida. Se encarecer por ser envernizada, não é tão necessário assim também, sabe, tem um líquido que a gente coloca também na placa. Sabe que tem um líquido que a gente compra, que eu usava o líquido, tu passa na placa pra não oxidar, depois de soldar tu podes passar o líquido, aí não oxida. Agora, claro, o verniz é outra coisa. Isso aí é de televisão.

\section{E você aproveita isso aqui?}

Os capacitores aí eu já tirei todos, sabe, os capacitores que a gente tira das placas de TV são de superior qualidade do que tu compra no comércio, porque aqui passa pelo controle de qualidade, né? Então os capacitores são, bah, são de primeira linha, inclusive os resistores

\section{Aqui tem um bocado ainda}

Tem, eu tirei os bons aqui, uns que eu usava muito, pelo valor também. Eu uso muito 220 nano e 100 nano, resistor às vezes quando eu preciso também eu tiro. O cara confere, né, tá bom isso aí, é uma placa de TV nova, tá condenada, o processador que pifou, aí eu desmonto ela, não adianta mais...

\section{O processador é esse aqui}

Esse aqui é o processador de vídeo, esse aqui é o geral, de vertical e horizontal. Então com um bocado de problema aí, nem tem mais pra vender isso aí.

\section{E você tem um acervo aqui, de placas}

Sempre o cara aproveita alguma coisa, né? (risos)

\section{E tem vindo muita coisa pra consertar?}

Tou sempre consertando, né? Semana passada entreguei dois amplificadores, eu faço tudo sozinho, o guri ajuda muito pouco, pelo contrário, tenho que cuidar do guri aí.

Comprei um sargento, conhece sargento, né? Isso aqui me fazia uma falta, rapaz, eu tive lá olhando, eu comprei uns negócios e disse "agora eu vou comprar", quer ver, eu preciso botar aqui. Isso aqui é a furadeirinha minha, eu tenho outra de mão, mas a de bancada é essa aqui, pra fazer as furações das placas e do gabinete, aí eu uso isso aqui, o sargento ajuda a prender umas placas, eu preciso, bah, fazia uma falta medonha isso aí, ajuda mesmo. O cara quer fixar alguma coisa, né? Esses acrílicos por exemplo, eu serrei com serra tico-tico mesmo,

\section{E aí tem vindo mais o quê pra você consertar?}

O que eu pego mais é amplificador, mesmo, televisão eu parei de pegar. (mexendo nos esquemas) Ó, tá aqui o esquema completo, esse aqui é o esquema da gatorra. Aqui tá funcionando, ó, aqui recebe o pulso. Bah, mas aqui não tem a chave, aqui não tá o sistema de pulso mesmo, só a entrada aqui, o diodo, por isso que eu te falei que é nem um 
cachorro pegando o rabo. Aqui, ó, tu aplica o sinal aqui, entra na base, né? Aí ele passa pelo capacitor e entra no coletor, então ele fica assim, porque a saída é no próprio coletor, o sinal retorna, por isso que fica "puuuu" [imita o som com a boca], é legal isso aqui, né? Os caras chamam de, como é que é..., circuito T, porque é um T aqui, tu viu, é um T com o capacitor, e um T aqui, é duplo-T. O sinal entra na base, ele vai pra saída e ele retorna de novo, tá sempre circulando. Interessante, né?

Esse aqui (mostra outro circuito) é que faz aquilo "prrrrr", tu já trabalhou com 555 ? Quem conhece bem ele é o Joly, e esse aqui é o contador, eu fiz uma gatorra, sabe, a da Lovefoxxx, tem um contador que eu botei uma chave de função, com cinco funções. Então tu bota ali no bumbo, fica "tum-tum-tum", aí tu não precisa fazer o bumbo, né? Aí tu faz os outros acompanhamentos, ou senão tu pode botar o bongô junto, outra função, aí eu botei esse contador. Porque, veja bem, ele larga assim dez sinais, se tu quiser ele pode largar os dez juntos, e o cara pode botar dois, três, por exemplo o bongô, o tambor e o bumbo (faz com a voz), aí tu faz os outros efeitos nela. Dois caras, uma eu vendi lá pro Rio de Janeiro, uma gatorra assim, o cara pediu, aí eu boto esse 4017 aqui, ó, aí ele recebe um sinal daqui, e sai tudo aqui, esse aqui é o oscilador, aí manda pra cá, e aqui liga na saída ali, cada um tu inveja lá.

Ele controla aqui, tu controla a velocidade dele lá, ó. O sinal sai daqui, entra ali e faz oscilar ali. Esse contador é legal, esse contador aqui dá pra fazer inúmeras coisas, por exemplo, seqüencial, aí se tu pegar a saída dele tu injetar num scr, de potência, aí tu liga lâmpadas de potência, que o sinal aqui é fraquino, não pode ligar uma lâmpada aqui, a não ser um LED, que LED não dá consumo. Mas se quiser uma coisa potente tu liga nesse SCR, aí da saída do SCR pode ligar num relê, aí tu liga um motor do tamanho de um bonde, tu sabe, né? Num relé o cara liga um monte de coisa, eu ligava relé num sistema de luz fluorescente, eu tenho na cozinha uma lâmpada que é a bateria, que eu mesmo montei. Eu usava um relé pra ligar dez lâmpadas, eu montei muito, lâmpada de emergência, quando faltava luz aí acionava o scr ligava o relé, e o relé acionava todas as lâmpadas.

Bah, esses potenciômetros aqui, o Joly me deu acho que uns 20, eu gastei tudo, eu tinha montado na gatorra do Marcelo Birck, depois montei essa aqui, depois tinha mais uma outra que só ano passado eu vendi três gatorras. É, foi a 19, a 19 é a tua, né?

\section{A 19 é a minha}

Ah, não, então foi na tua que eu tinha usado uns potenciômetros, não, foi na 20, 21 e 22, na tua eu ainda não tinha ganho não.

\section{É porque teve a Aquárius no meio}

A 20 foi aquela de dois braços que eu vendi pro Alê Fonseca, a 21 é do Marcelo Birck 


\section{A 20 é do Joly}

A do joly?

\section{A de dois braços ficou sem número}

Eu acho que não é a do Joly não, não é a $18 ?$

\section{A 18 era pra ser do Joly mas aí o Paulo Abraão comprou. A minha é a} 19, aí tu fez outra pro Joly quando vocês fizeram o rolo do amplificador, e a outra, de dois braços, ficou pelo meio ali...

Ah, não botei, tchê, eu chamei ela de Galática, de Aquárius, botei um modelo nela, foi aí que eu me confundi. Então eu pulei, aí eu deixei a minha 22.

\section{Aí a 21 é do Birck e a 22 é a tua...}

Foi mesmo, não tinha número, eu botei só o modelo, não botei display nela. É mesmo, agora que eu tou me lembrando. E o Alê comprou essa de dois braços que tá na capa ali, ele comprou duas, que número que era a outra dele, não era 17 ou 16, que o Joly que arrumou, aí deixei pra ele lá. Foi o Alê, nós sempre conversamos ali, no Facebook, eu não conheço pessoalmente ele, e já fizemos um monte de negócio.

Quem fez aquele disco pra mim, no fim, foi o Du, irmão do Bruno, foi ele, tchê, eu tinha gravado aquela música ali do "Meu nome é Tony", quem fez a composição, metade, eu arrumei ela, foi eu o Du e o Bruno Ramos. Sabe que ele é advogado, formado, né, ele que processou a Ordem dos Músicos, aí que os caras gostaram quando eu falei lá, ele processou e ganhamos a liminar, depois ele foi, a sentença, e deram lá mil reais de música, pra aqueles caras lá é uma mixaria, né? E queriam recorrer pra pagar mil reais, isso aí não é multa, mas eles se ferraram comigo, me largaram de mão. Eu ainda fui embaixo do escritório deles, eu e o Gui lá com a caixinha de som na calçada, eles ficavam olhando lá de cima e eu falando lá embaixo, e todo mundo olhando, e eles ficaram olhando lá de cima, no escritório da OMB em São Paulo. O Gui que descobriu o endereço, "vamo lá, Tony, vamo lá", os caras gostaram ali quando eu falei. Aí quem fez essa mão toda foi o Bruno, bah, ele me deu o papel, eu cheguei a te mostrar, eu tenho com a gatorra, da ordem da juíza federal, eu até carrego junto, ninguém pode me incomodar, eu mostro na cara, né? Que eu posso tocar em qualquer lugar, não pode exigir porcaria nenhuma de carteira, que história furada. E foi no SESC Pompéia, aconteceu isso lá. Do show que depois no próximo ano que eu fiz, os caras não queriam se incomodar e disseram "Não é pelo Tony, é porque os caras vem encher o saco aqui", aí o cara do SESC não queria, né, é problema. Mas no próximo ano lascou e bah, e o cara "agora sim, agora vem, já tem os papéis, o Bruno disse que tá liberado, ninguém vai te incomodar". Aquilo ali é inconstitucional, a própria juíza disse, ela disse que ninguém tem que ter licença, a não ser quando é, ela botou exemplo, como um médico, que tem responsabilidade. E eu não ofereço perigo à sociedade nenhum, então como é que vai impedir, a juíza largou um monte de argumento em cima, eu tenho 
o processo, tem cinco folhas, eu tenho aí, eu sempre carrego na gatorra, junto ali. E na época queriam me cobrar a carteira 250 pilas, ó, pra quê que eu vou dar 250 reais pra eles, sem direito a porcaria nenhuma, eu não vou ganhar nada com isso, não te protege, nem tem um direito nem nada, é uma sujeira, né?

Aí no outro ano eu fui lá, aí eu falei, abri o bocão também, quando eu fui tocar no palco, aí toquei a música do "Meu nome é Tony", e o Bruno é que fez a composição, na verdade, eu lapidei ela só, eu arrumei outras coisas, outras frases, eu coloquei, e ficou ali o "Meu nome é Tony". Ah, eu vendi mais de mil cópias daquele ali, São Paulo eu vendi bastante ali. Eu tenho só um aí, o meu, bah, no fim aconteceu um problema na enchente, sabe que eu perdi tudo aqui, né? Daí o Du me deu o que sobrou lá, tinha parece que uns 100 ou 150 encartes, prontinhos, aí pegou uma enchente e molhou um pouco, aí eu recuperei, mas depois na outra que veio ano passado, em 2013, veio outra que entrou um metro. Olha ali a marca (mostra a marca da enchente na parede), imagina, isso aqui virou um rio. Aí acabou, eu tinha colocado em cima do guarda-roupa, o guarda-roupa desmontou, o multiteste igual a esse aqui, o Paulo Beto me deu novinho, na gaveta da estante da sala que eu tava guardando, nunca eu ia imaginar que ia ficar um metro, né? Aí perdi. Revistas minhas que eu tinha, até da Rolling Stone, da Europa, que eu trouxe lá de Londres, foi tudo, fita K7, fita de vídeo, televisão e som, foi tudo. A moto cobriu assim, tava aqui na rua, a moto sumiu, imagina um metro. Mas eu fiquei com raiva por causa das revistas, aí consegui tirar umas folhas, pelo menos, as folhas mais importantes, consegui recuperar também, eu consegui colar elas. Eu tinha mais de 20, eu tinha até da Capricho uma matéria minha. Tu conheceu o Six, bah, o Six é um baita faixão, né? Cada vez que eu ia lá ele tava, ele sempre dizia "Eu sou o maior fã teu de São Paulo". Ele namorou aquela guria lá, a Ana, meio japonezinha, sabia que ela comprou um batucador meu de leilão, eu fiz um leilão lá no Mancha.

E as primeiras que eu fiz, que eu coloquei um sintonizador de TV de plástico, no lugar disso aqui, tu chegou a ver aquelas primeiras gatorras? A 4, a 5, a 6, eu tinha, né, aí terminou, é de sintonia de TV, aí eu coloquei os 12 timbres pra ti sintonizar, aí tu podia sintonizar todos os 12. Aí terminou, né, eu não consegui mais e não tem pra vender mais, aquilo, aí eu uso potenciômetro.

\section{É, a minha é nesse esquema aqui}

[sobre a 22] Os caras gostaram, acharam bonita pra caramba, e esse aqui é $5 \mathrm{~mm}$ (placa de acrílico), a espessura dele aqui, deu um trabalhinho pra dobrar ele, a gente fez na água fervendo, pra ficar na feição. E esse joguinho aqui eu faço com resistor.

[mostra caixa de montagem]

Ah, essa caixinha quem me deu foi o Joly, já pensou que legal, essa caixinha aí? E é ferro, tchê, é chapa mesmo, não é alumínio não, isso aí. Eu achei legal porque o 
transformador que vai aí é $400 \mathrm{~mA}$, eu não preciso mais do que isso aí, coube certinho, pode ver que ele ficou prensadinho aí, o transformador, nem se mexe. Aí deu pra colocar os jacks aí dos p10, chavezinha, tudo, não tem controle de volume nem nada, o controle fica aqui, é só entrada e saída dele. Tem a chavezinha, tem a chave de trocar o volts aí. Ficou bem prático, isso aí. Eu tenho que fazer o case dela, eu tive sorte sabe, que deu certinho [mostra o case da gatorra 01] o tamanho dela, mas é da outra gatorra, a coitada ficou pelada, olha a veinha. Olha o peso dela, tu viu? Mas tu sabe que isso é de madeira maciça, na época eu não tinha ideia de fazer, eu fiz à minha moda, comprei uma chapa de madeira na madeireira e fiz o buraco ali, taquei as placas pra dentro, enfiei tudo pra dentro aí. Se tu olhasse dentro tu ia te apavorar, tá uma teia de aranha isso aí horrível aí dentro. Eu nem gosto de mexer nela, eu já abri ela duas vezes já pra dar uma revisada, mas é pesada, né?

\section{Aqui tem um botão secreto...}

Ah é, sabe o que que é, deu um problema no chipozinho aqui, aí eu fiz outra placa e botei aqui dentro pra não ficar sem, mas eu tenho que trocar. Eu não mexi ainda, eu não gosto muito de mexer nela, porque é um protótipo, né? Eu sempre faço uma pra mim, a segunda que eu fiz, número 02, tchê, foi o Binho acabou comprando...

\section{Aquela vermelha, né?}

Isso, agora eu fiz essa aqui pra mim, quero ver, os caras vão acabar comprando. Essa aí é guerreira, foi pra Europa, atravessou o oceano, essa aí é famosa, até o Gruff pegou ela lá, tocou com ela e gostou. Um dia o cara perguntou se eu vendo, bah, se eu vender eu depois vou me arrepender, né? Ficar com saudades, pô, a gatorra que me deu o nome, me deu muito trabalho pra fazer, fiz sozinha o trabalho todo. Levei mais de ano, estraguei muita peça fazendo, fazia quebrando a cabeça, ficava horas em cima dela.

\section{Você lembra quanto tempo faz?}

Ah, eu levei um ano fazendo isso aí. Fazia placa, não dava nada certo, problema, né? O cara sozinho né, tchê, sem ajuda de ninguém pra dar um palpite nem nada. Eu fiquei um ano estragando e abrindo e não dava certo as coisas que eu queria, problema de pulso dela ali. Aí fui indo, até que consegui acertar os pontos. Daí eu fiz a do Binho, o Binho trabalhava de cinegrafista só, e ele me conheceu e "Pô, e tu me vende ela?", tava conversando num táxi. Eu vim sem gatorra pra cá, eu tinha levado ela pra tocar, eu toquei com ela lá, daí o Binho, aquela do Binho é muito bonita... Tu tava lá no Mancha, aquele dia que o cara fez com o telão, tu tava lá aquele dia, né? Que o cara tocou essa do Binho, com uma filmagem muito louca que ele fez lá, com a gatorra do Binho ${ }^{3}$ O Binho já emprestou ela pra várias pessoas.

3 Tony se refere à apresentação de André Damião Bandeira na Casa do Mancha, em 21 de março de 2015. A peça e a apresentação podem ser vistas em < https://www.youtube.com/watch?v=oOIuIAaIEkE $>$ e $<$ https://youtu.be/4a2-HKevR_A?t=2h1m32s $>$. Acesso em 10 de janeiro de 2018. 
[Sobre uma foto na parede] Aquela ali qual que é, você lembra?

Essa aí é do Nick McCarthy, essa aí eu sei, é a 7. Sabe essa foto aí, conhece o Sérgio Ugeda, né, essa foto foi tirada no SESC Copacabana, no Rio. E daí o Sérgio tocou com ela e o Gui tocou com a dele, nós três tocamos a gatorra lá. Logo em seguida o Du, ele era o empresário da Cansei, lá da Lovefoxxx, ele foi pra Europa e levou lá pra Escócia e entregou pro Nick. E depois eu toquei com ele lá no palco, lá na Escócia mesmo. Eu tenho as fotos aí, eu e o Nick tocando. 



\section{APÊNDICE C - Material complementar}

\section{C.1 Registros em vídeo}

Registros em vídeo de instrumentos mencionados no trabalho, disponíveis online:

- Demonstração do Bolo de Noiva: < https://youtu.be/_siiL-yWHmU>. Acesso em 14 de fevereiro de 2017

- Demonstração da Tábua Mobile: <https://youtu.be/6IzH0SQ6UAQ> . Acesso em 14 de fevereiro de 2017

- Demonstração do Teclado sísmico: < https://youtu.be/S5S1xlSHh2M>. Acesso em 27 de maio de 2018.

- Mesa cordas, do duo O Grivo < https://www.youtube.com/watch?v=xvwsmW9CEsU>. Acesso em 18 de junho de 2017

- Vídeo de instalação com os instrumentos Polyradiotron e Percussiomixer de Eloi Silvestre: <https://www.youtube.com/watch?v=CF7EgfDjIF4>. Acesso em 27 de maio de 2018.

- Canal do YouTube de Cadós Sanchez: <https://www.youtube.com/channel/UCAybuiaTtyDl9fSi Acesso em 11 de janeiro de 2017.

- Canal do Youtube do Ibrasotope: <https://www.youtube.com/channel/UC6q5GmUkbxDz8kCB? Acesso em 14 de fevereiro de 2017.

- Canal do YouTube de Henrique Iwao: < https://www.youtube.com/channel/UC21C8DOSKKPxY Acesso em 14 de fevereiro de 2017.

- Aparelhos e ritimifiqueitor de Chico Machado: < https://vimeo.com/118200400>. Acesso em 14 de fevereiro de 2017.

- Matéria do portal Trama Virtual sobre o festival Troca Brahma: <https://www. youtube.com/watch?v=6IuyzxSf-6Q>. Acesso em 01 de fevereiro de 2018.

- Programa Singulares, da TVE, sobre Tony da Gatorra: < https://www.youtube.com/ watch? $\mathrm{v}=$ WS9EWO03k1k\&list=PLEVHKqwu2VEgusu8aXNZzvQq4HuTxuPj6\&index= 3>. Acesso em 14 de maio de 2018. 
- Lee Ranaldo, integrante da banda Sonic Youth utilizando a gatorra em concerto no Rio Grande do Sul: < https://www.youtube.com/watch?v=4X_OlOXQUtM > $<$ https://www.youtube.com/watch?v=wDynw7SUPMs $>$. Acesso em 29 de maio de 2018 .

- Roy "Futureman" Wooten: < https://www.youtube.com/watch?v=VI3XekUlVmo>. Acesso em 10 de janeiro de 2018.

\section{C.2 Outros artistas}

Camila Sposati Artista visual e escultora, trabalha com diversos meios e materiais. Na série Phonosophia criou uma série de instrumentos de argila com formas relacionadas com outro trabalho, o Teatro Anatômico da Terra. <http://camilasposati. com/category/phonosophia/>.

DaDa Attack DaDa Attack é o nome artístico de Saulo Pais, que se define como artista "multidisciplinar, produtor musical e maker que transforma suas experiências em arte livre e explora diversas técnicas em seu processo de criação"1. Atua regularmente como facilitador de oficinas de circuito alterado e construção de dispositivos eletrônicos. $<$ http://dadaattack.com/>.

Glerm Guilherme Soares é artista plástico, músico e ativista de software livre, cujas obras incluem instrumentos físicos como o Toscolão ${ }^{2}$, uma espécie de violão simplificado, e programações em Pure Data compartilhadas publicamente para uso, entre eles o patch Navalha ${ }^{3}$, que trabalha com o recorte e recombinação de fragmentos sonoros. Atualmente é professor da Universidade Federal do Recôncavo da Bahia. < https: //ufrb.academia.edu/GuilhermeSoares>

O Grivo O Grivo é um duo formado em 1990 por Marcos Moreira e Nelson Soares, e baseado em Belo Horizonte - MG. Desde o início de suas atividades tem transitado entre uma atuação como grupo musical nos meios da música experimental e como artistas sonoros no meio das artes de galeria, de forma autônoma ou complementando o trabalho de outros artistas como Lucas Bambozzi ${ }^{4}$. Uma característica do trabalho do duo é o uso de amplificação como forma de revelar aspectos sonoros pouco perceptíveis sem este recurso, assim como o uso de readymades sonoros, além da integração com instrumentos tradicionais modificados e do uso de recursos eletroeletrônicos. $<$ http://www.ogrivo.com/>.

1 Disponível em: <http://dadaattack.com/about.html>. Acesso em 27 de maio de 2018.

2 Disponível em: <https://vimeo.com/303234>. Acesso em 01 de outubro de 2013.

3 Disponível em: < http://artesanato.devolts.org/?page_id=443>. Acesso em 01 de outubro de 2013.

4 Disponível em: < https://nararoesler.art/artists/53-o-grivo/>. Acesso em 27 de maio de 2018. 
Duo n-1 Duo formado por Giuliano Obici e Alexandre Fenerich, em 2007, cujas apresentações combinam o uso de dispositivos sonoros físicos - incluindo-se aí brinquedos diversos que produzem sons e também discos de vinil preparados - com programações nos ambientes Max/MSP e PureData, como no caso das obras "O jardim das gambiarras chinesas" e "Metaremix". O trabalho do duo é parte da pesquisa apresentada em Lima (2013), e também é discutido em Obici (2014) e Scarassatti (2015).. <http://n-1.art.br/>

Rede MetaReciclagem Grupo formado em 2002 por membros de diversos perfis, compartilhando o interesse em inclusão digital, buscando "atualizar a antropofagia no movimento hacker e o tropicalismo no software livre"5, a Rede MetaReciclagem atua por meio de ações como mutirões e também pela multiplicação de frentes de ação autônomas, chamadas pela comunidade de Esporos ${ }^{6}$. Obici aponta para a simultaneidade na criação do neologismo gambiologia pela Rede Metareciclagem e pelo coletivo Gambiologia ${ }^{7}$. <https://metareciclagem.github.io/>

Coletivo Gambiologia Coletivo baseado em Belo Horizonte e formado por originalmente por Fred Paulino, Lucas Mafra e Paulo Henrique Pessoa, o "Ganso" , que atuou entre 2008 e 2015, propondo um "diálogo entre a tradição brasileira de improvisação e a arte eletrônica"9. Seus trabalhos se dividiam entre projetos independentes, trabalhos comissionados, realização de oficinas, publicações como a revista Facta ${ }^{10}$ e também artigos acadêmicos ${ }^{11}$. Após a dissolução do coletivo, seus membros continuam atuando de forma independentemente com arte e design. Segundo descrição do próprio grupo, "Gambiologia é a 'Ciência da Gambiarra'. É pesquisar como a tradição brasileira de adaptar, improvisar, encontrar soluções simples e criativas para pequenos problemas cotidianos pode ser aplicada hoje, no contexto da arte eletrônica". Segundo Fernandez (2013, p. 153), a escolha do nome pelo grupo serve como uma espécie de tradução do conceito de bricolagem para a realidade brasileira. < http://www.gambiologia.net/>.

Thelmo Christovam Thelmo Christovam é músico, artista sonoro e profissional do áudio baseado em Olinda, Pernambuco. Seu trabalho inclui improviso livre e gravações de campo. <https://thelmocristovam.bandcamp.com>

Rodrigo Olivério <http://rodrigooliverio.blogspot.com.br $>$.

5 (OBICI, 2014, p. 63)

6 Disponível em: <https://metareciclagem.github.io/listas/esporos.html>. Acesso em 27 de maio de 2018.

7 (OBICI, 2014, p. 65)

8 Como designer e artista gráfico, Paulo Henrique Pessoa está em atividade desde os anos 1980.

9 Disponível em: < http://www.gambiologia.net/blog/apresentacao >. Acesso em 27 de maio de 2018.

10 Disponível em: < http://www.facta.art.br>. Acesso em 24 de outubro de 2015

11 Disponíveis em: <http://www.gambiologia.net/blog/biblioteca>. Acesso em 22 de outubro de 2015 
Adriano Castelo Branco Construtor de instrumentos musicais voltado para o uso pedagógico. <https://www.youtube.com/watch?v=0Mwts8xOqV0\&feature=youtu.be $>$.

Thiago Salas Facilitador de oficinas de gambiarras eletrônicas. < https://soundcloud. com/thiagosalas>

\section{C.3 Sítios de artistas e Luthiers}

Luthiers cuja produção eu encontrei ao longo desta pesquisa, por indicação em informações pessoais ou em pesquisas online, e que colaboraram de alguma forma para o trabalho como um todo, aos quais agradeço.

Z'ev <http://www.rhythmajik.com/>

Survival Research Laboratories <http://www.srl.org//>

Victor Gama <http://www.victorgama.org>

Yuri Landman <http://www.hypercustom.nl/>

Marcos Kaiser <http://www.marcoskaiser.com/>

William Takahashi - <https://www.youtube.com/watch?v=wILNpVmZ0aM>. Construtor de cravos sediado em São Bernardo do Campo - SP

\section{Abel Vargas}

Curso de luteria da UFPR < http://www.luteria.ufpr.br/curso.html>

Curso de Luteria do Conservatório de Tatuí < http://www.conservatoriodetatui.org. $\mathrm{br} / \mathrm{cursos} /$ luteria/>

Marcos Ximenes < http://www.mximenes.com/> - Construtor de flautas doce sediado em Fortaleza - CE

Diogo Leal <https://www.diogo-leal.com/> - Flutier brasileiro sediado

Alexander Hopkins < http://www.hopkinslutes.com/>

Lee Connah < http://www.folkherosandwich.com/instrumentphotos.php>

Ron Sword <http://therealronsword.blogspot.com.br/>

Yuri Landman < https://www.youtube.com/watch?v=CN-wj5MKD1E > < https://www. premierguitar.com/articles/23988-diy-thurston-moores-drone-guitar-project $>$ 
Keith Rowe <http://preparedguitar.blogspot.com.br/2014/04/keith-rowe-13-questions. html $><$ https://en.wikipedia.org/wiki/Keith_Rowe $>$

John Schneider < http://www.johnschneider.la/> < https://rowman.com/ISBN/9781442237889/ The-Contemporary-Guitar-Revised-and-Enlarged-Edition $>$

R.M. Mottola < http://www.liutaiomottola.com/>

Stratmann <http://www.stratmann-gitarren.de/>

Nicolas Bras Luthier experimental e mantenedor das páginas $<$ http://rareandstrangeinstruments. com/> e <http://www.musiquesdenullepart.com/>

Victor Gama <http://www.victorgama.org $>$ 